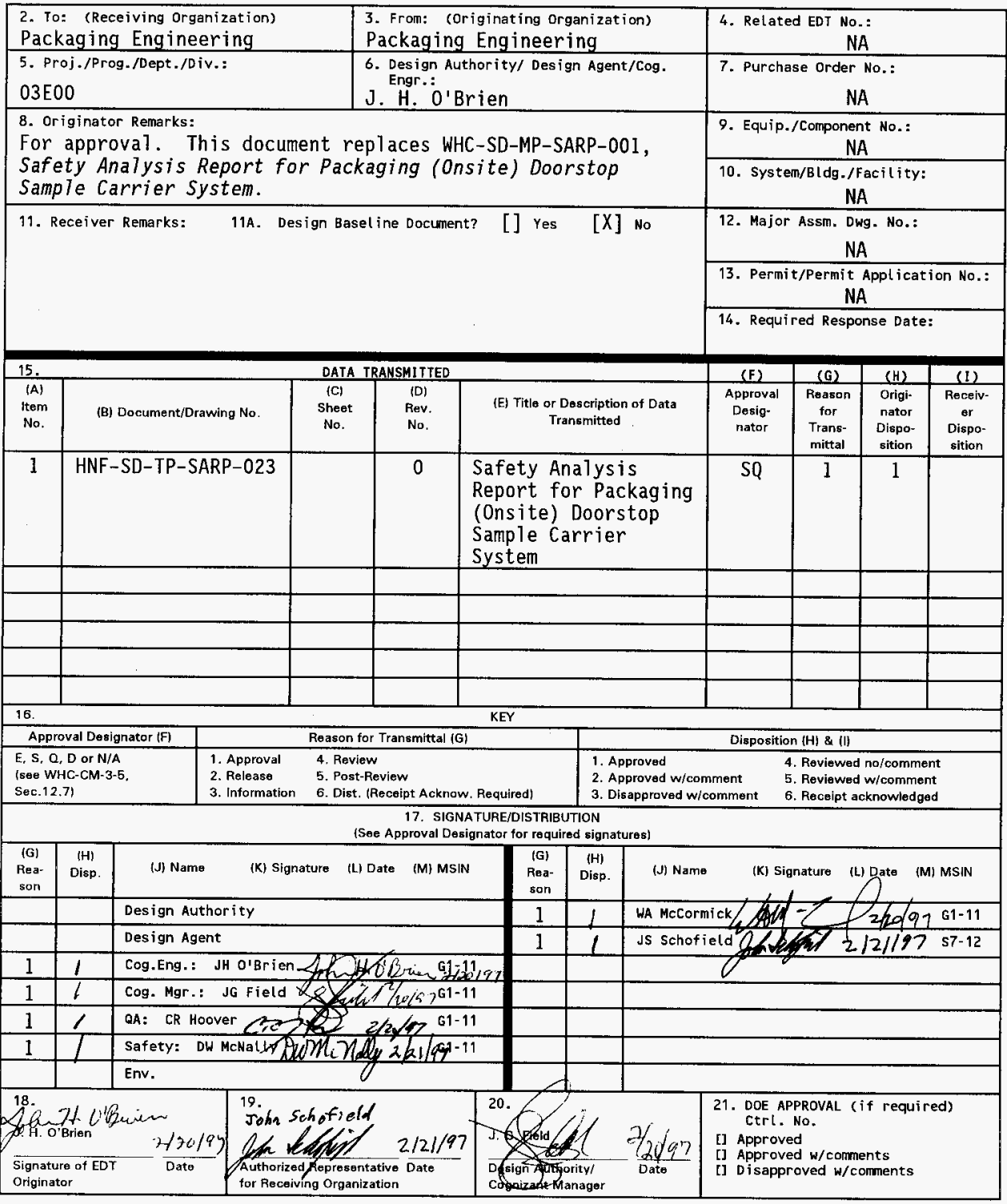




\title{
Safety Analysis Report for Packaging (Onsite) Doorstop Sample Carrier System
}

\author{
J. H. O'Brien \\ Rust Federal Services Inc. Northwest 0perations, Rich1and, WA 99352 \\ U.S. Department of Energy Contract DE-AC06-96RL13200
}

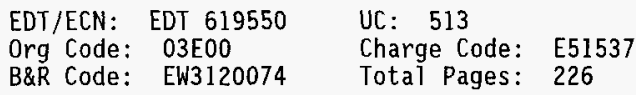

Key Words: Doorstop, N-55 overpack, DOT 208-L drum

Abstract: The Doorstop Sample Carrier System consists of a Type B certified N-55 overpack, U.S. Department of Transportation (DOT) specification or performance-oriented 208-L (55-gal) drum (DOT 208-L drum), and Doorstop containers. The purpose of the Doorstop Sample Carrier system is to transport samples onsite for characterization. This safety analysis report for packaging (SARP) provides the analyses and evaluation necessary to demonstrate that the Doorstop Sample Carrier System meets the requirements and acceptance criteria for both Hanford Site normal transport conditions and accident condition events for a Type B package. This SARP also establishes operational, acceptance, maintenance, and quality assurance $(Q A)$ guidelines to ensure that the method of transport for the Doorstop Sample Carrier System is performed safely in accordance with WHC-CM-2-14, Hazardous Material Packaging and Shipping.

TRADEMARK DISCLAIMER. Reference herein to any specific comercial product, process, or service by trade name, trademark, manufacturer, or otherwise, does not necessarily constitute or imply its endorsenent, recommendation, or favoring by the United States Government or any agency thereof or its contractors or subcontractors.

Printed in the United States of America. To obtain copies of this document, contact: Document Control Services, P.O. BOK 950, Mailstop H6-08, Richland WA 99352, Phone (509) $372-2420$;

Fax (509) 376-4989.

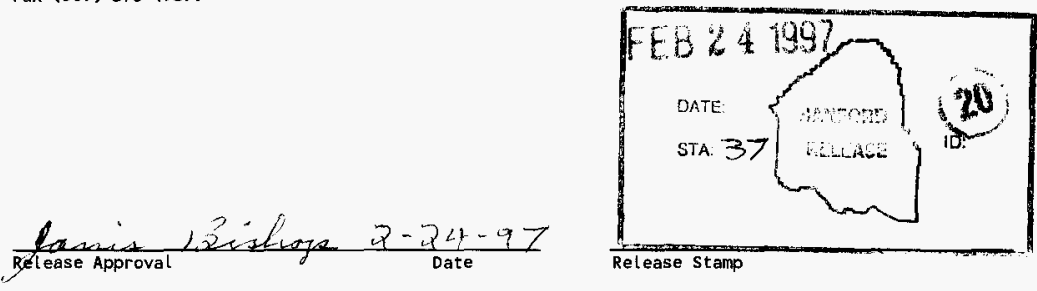




\section{LIST OF EFFECTIVE PAGES}

\begin{tabular}{|l|c|c|}
\hline \multicolumn{1}{|c|}{ Page } & Revision & Comment \\
\hline & 0 & EDT \\
\hline & 0 & SD Cover \\
\hline iii-xii & 0 & LOEP \\
\hline A1-1 - A1-4 & 0 & TOC \\
\hline A2-1 - A2-6 & 0 & \\
\hline A3-1 - A3-4 & 0 & \\
\hline$A 4-1-A 4-6$ & 0 & \\
\hline$A 5-1-A 5-4$ & 0 & \\
\hline A6-1 - A6-6 & 0 & \\
\hline$A 7-1-A 7-7$ & 0 & \\
\hline A8-1 - A8-2 & 0 & \\
\hline$A 9-1-A 9-2$ & 0 & \\
\hline$A 10-1-A 10-12$ & 0 & \\
\hline$B 1-1-B 1-4$ & 0 & \\
\hline$B 2-1-B 2-4$ & 0 & \\
\hline$B 3-1-B 3-2$ & 0 & \\
\hline$B 4-1-B 4-10$ & 0 & \\
\hline$B 5-1-B 5-16$ & 0 & \\
\hline$B 6-1-B 6-2$ & 0 & \\
\hline$B 7-1-B 7-46$ & 0 & \\
\hline$B 8-1-B 8-48$ & 0 & \\
\hline$B 9-1-B 9-18$ & 0 & \\
\hline$B 10-1-B 10-12$ & 0 & \\
\hline & & \\
\hline
\end{tabular}


HNF-SD-TP-SARP-023 Rev. 0

CONTENTS

PART A: PACKAGE DESCRIPTION AND OPERATIONS

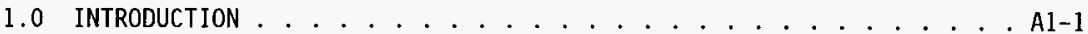

1.1 GENERAL INFORMATION . . . . . . . . . . . . . . . . . A1-1

1.2 SYSTEM DESCRIPTION . . . . . . . . . . . . . . . . . . . . Al-1

1.3 REVIEW AND UPDATE CYCLES ................. . . A1-3

2.0 PACKAGING SYSTEM . . . . . . . . . . . . . . . . . A2-1

2.1 CONFIGURATION AND DIMENSIONS ................. . . . . . .

2.2 MATERIALS OF CONSTRUCTION ................ . A2-4

2.3 MECHANICAL PROPERTIES OF MATERIAL . . . . . . . . . . . . . . A2-4

2.4 DESIGN AND FABRICATION METHODS . . . . . . . . . . . . . . A2-5

2.5 WEIGHTS AND CENTER OF GRAVITY . . . . . . . . . . . . . . . . A2-5

2.6 CONTAINMENT BOUNDARY . . . . . . . . . . . . . . . . A2-5

2.7 CAVITY SIZE . . . . . . . . . . . . . . . . . . . A2-6

2.8 HEAT DISSIPATION . . . . . . . . . . . . . . . . . . A2-6

2.9 SHIELDING . . . . . . . . . . . . . . . . . . . A2-6

2.10 LIFTING DEVICES . . . . . . . . . . . . . . . . . . . . . A2-6

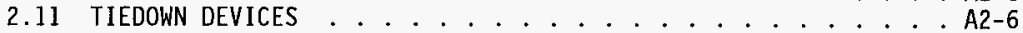

3.0 PACKAGE CONTENTS . . . . . . . . . . . . . . . . . . A3-1

3.1 GENERAL DESCRIPTION . . . . . . . . . . . . . . . . . . A3-1

3.2 CONTENT RESTRICTIONS ................ . . . . . . . . . .

3.2.I Radioactive Materials . . . . . . . . . . . A3-3

3.2.2 Nonradioactive Materials . . . . . . . . . . A3-3

4.0 TRANSPORT SYSTEM . . . . . . . . . . . . . . . . . . . . A4-1

4.1 TRANSPORTER ...................... . . . . . . . . .

4.2 TIEDOWN SYSTEM . . . . . . . . . . . . . . . . . A4-1

4.3 SPECIAL TRANSFER REQUIREMENTS . . . . . . . . . . . . . . . . A4-1

4.3.1 Routing and Access Control . . . . . . . . . . . . . A4-1

4.3.2 Radiological Limitations ... . . . . . . . . . . A4-1

4.3.3 Time Restrictions . . . . . . . . . . . . . . . A4-3

4.3.4 Speed Limitations . . . . . . . . . . . . . . . . . . A4-6

4.3.5 Environmental Conditions . . . . . . . . . . . . . A4-6

4.3.6 Frequency of Use and Milage Limitations . . . . . . . A4-6

4.3.7 Escort and Emergency Response . . . . . . . . . . A4-6

4.3.8 Exclusive Use ................ A4-6

5.0 ACCEPTANCE OF PACKAGING FOR USAGE . . . . . . . . . . . . . . . A5-1

5.1 NEW PACKAGE ACCEPTANCE TESTING . . . . . . . . . . . . A5-1

5.1.1 Acceptance Requirements . . . . . . . . . . . . . . A5-1

5.1.2 Inspection and Testing . . . . . . . . . . . . A5-1

5.1.3 Documentation . . . . . . . . . . . . . . A5-2

5.2 PACKAGING FOR REUSE . . . . . . . . . . . . . . . A5-2

5.2.1 Acceptance Requirements . . . . . . . . . . A5-2

5.2.2 Inspection and Testing . . . . . . . . . . . A5-3

5.2.3 Documentation ................ A5-4 


\section{CONTENTS (cont)}

6.0 OPERATING REQUIREMENTS .......................... A6-1

6.1 GENERAL REQUIREMENTS . . . . . . . . . . . . . . . . A6-1

6.2 LOADING PACKAGE . . . . . . . . . . . . . . . . . . . . A6-1

6.2.1 Lead Pak Cylinder . . . . . . . . . . . . . . A6-1

6.2.2 Bottled Samples in Can . . . . . . . . . . . . . A6-1

6.2.3 Doorstop Sample Carrier . . . . . . . . . . . A6-2

6.2.4 Doorstop Container . . . . . . . . . . . . . . A6-2

$6.2 .5 \mathrm{~N}-55$ Overpack . . . . . . . . . . . . . . A6-3

6.2.6 Lifting ................... . . . . . . . . . .

6.2.7 Installation of Package onto Transport Vehicle . . . A6-4

6.3 RECEIPT OF PACKAGE . . . . . . . . . . . . . . . . . A6-4

6.3.1 Off-Loading ................. . A6-4

6.4 EMPTY PACKAGE (PACKAGING) .. . . . . . . . . . . . . . . A6-5

6.5 EXCESSIVE DOSE RATE TRANSPORT . . . . . . . . . . A6-5

7.0 QUALITY ASSURANCE REQUIREMENTS . . . . . . . . . . . . . . . A7-1

7.1 INTRODUCTION . . . . . . . . . . . . . . . . . . . . . . A7-1

7.2 GENERAL REQUIREMENTS ................... . . . . A7-1

7.3 ORGANIZATION . . . . . . . . . . . . . . . . . . . . A7-3

7.4 QUALITY ASSURANCE ACTIVITIES . . . . . . . . . . . . . A7-3

7.4.1 Design Control ................ . . A7-3

7.4.2 Procurement and Fabrication Control . . . . . . . A7-3

7.4.3 Control of Operation/Processes . . . . . . . . . . . . A7-4

7.4.4 Control of Inspection and Testing . . . . . . . . . A7-4

7.4.5 Control of Operations and Maintenance . . . . . . . . A7-4

7.4.6 Test Control . . . . . . . . . . . . . . . . A7-5

7.4.7 Control of Measuring and Test Equipment . . . . . . . A7-5

7.4.8 Control of Nonconforming Items . . . . . . . . . . A7-5

7.4.9 Corrective Action . . . . . . . . . . . . . . . . . A7-5

7.4.10 Quality Assurance Records and Document Contro 1 . . . A7-6

7.4.11 Audits . . . . . . . . . . . . . . . . . . A7-6

7.5 SARP CONTROL SYSTEM . . . . . . . . . . . . . . . A7-6

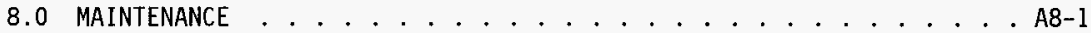

8.1 GENERAL REQUIREMENTS . . . . . . . . . . . . . . . . . . A8-1

8.2 MAINTENANCE . . . . . . . . . . . . . . . . . A8-1

8.3 DOCUMENTATION . . . . . . . . . . . . . . . . . . . A8-2

9.0 REFERENCES . . . . . . . . . . . . . . . . . . . . A9-1

10.0 APPENDICES . . . . . . . . . . . . . . . . . . A10-1

10.1 DRAWINGS .................... A10-1 
HNF-SD-TP-SARP-023 Rev. 0

CONTENTS (cont)

PART B: PACKAGE EVALUATION

1.0 INTRODUCTION . . . . . . . . . . . . . . . . . . B1-1

1. I SAFETY EVALUATION METHODOLOGY ................. . . . B1-1

1.2 EVALUATION SUMMARY AND CONCLUSIONS ............. . . . . . . . 1

1.2.1 Contents . . . . . . . . . . . . . . . . . . . B1-1

1.2.2 Radiological Risk .............. . . Bl-1

1.2.3 Containment . . . . . . . . . . . . . . B1-2

1.2 .4 Shielding . . . . . . . . . . . . . Bl-2

1.2 .5 Criticality ................. . . Bl-2

1.2.6 Structural ................ . . B1-2

1.2.7 Thermal ..... . . . . . . . . . . . . . B1-2

1.2.8 Gas Generation . . . . . . . . . . . . . . B1-3

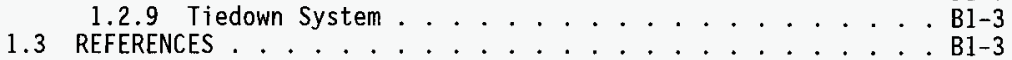

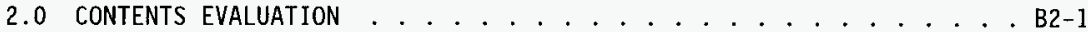

2.1 CHARACTERIZATION . . . . . . . . . . . . . . . . . . . B2-1

2.2 RESTRICTIONS . . . . . . . . . . . . . . . B B2-3

2.3 SIZE AND WEIGHT . . . . . . . . . . . . . . . . . . B2-3

2.4 CONCLUSIONS . . . . . . . . . . . . . . . . . B2-3

2.5 REFERENCES ...................... B2-3

3.0 RADIOLOGICAL RISK EVALUATION . . . . . . . . . . . . . . B3-1

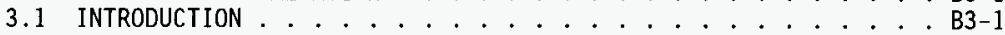

4.0 CONTAINMENT EVALUATION ...................... B4-1

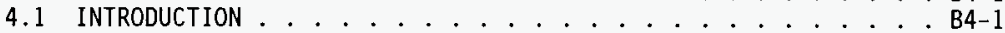

4.2 CONTAINMENT SOURCE SPECIFICATION . . . . . . . . . . . . B4-1

4.3 NORMAL TRANSFER CONDITIONS . . . . . . . . . . . . . B4-1

4.3.1 Conditions To Be Evaluated . . . . . . . . . . . . . . B4-1

4.3.2 Containment Acceptance Criteria . . . . . . . . . B4-1

4.3.3 Containment Model . . . . . . . . . . . . . . . B4-2

4.3.4 Containment Calculations . . . . . . . . . . . B4-2

4.4 ACCIDENT CONDITIONS ............................ B4-2

4.4.1 Conditions To Be Evaluated ............. . . B4-2

4.4.2 Containment Acceptance Criteria . . . . . . . . . . . B4-2

4.4.3 Containment Mode1 . . . . . . . . . . . . . B4-2

4.4.4 Containment Calculations . . . . . . . . . . . . B4-3

4.5 CONTAINMENT EVALUATIONS AND CONCLUSIONS . . . . . . . . . B4-3

4.5.1 Environmental Conditions . . . . . . . . . . . . . B4-3

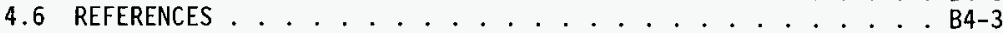

4.7 APPENDIX: CONTAINMENT ANALYSES . . . . . . . . . . . . B4-5

5.0 SHIELDING EVALUATION . . . . . . . . . . . . . . . . . . . B5-1

5.1 INTRODUCTION . . . . . . . . . B5-1

5.2 DIRECT RADIATION SOURCE SPECIFICATION . . . . . . . . . B5-1

5.2.1 Gamma Source................ . B5-1

5.2.2 Beta Source ................ . . B5-3

5.2.3 Neutron Source... . . . . . . . . . . . B5-3 


\section{CONTENTS (cont)}

5.3 SUMMARY OF SHIELDING PROPERTIES OF MATERIALS . . . . . . . B5-4

5.4 NORMAL CONDITIONS OF TRANSPORT ...................... B5-4

5.4.1 Conditions To Be Evaluated . . . . . . . . . . . B5-4

5.4.2 Acceptance Criteria . . . . . . . . . . . . . . B5-4

5.4.3 Shielding Mode1 . . . . . . . . . . . . . . . . B5-4

5.4.4 Shielding Calculations . . . . . . . . . B5-8

5.5 ACCIDENT CONDITIONS . . . . . . . . . . . . . . B5-8

5.5.1 Conditions To Be Evaluated . . . . . . . . . . . B5-8

5.5.2 Acceptance Criteria . . . . . . . . . . . . . B5-9

5.5.3 Shielding Model . . . . . . . . . . . . . . . . . B5-9

5.6 SHIELDING EVALUATION AND CONCLUSIONS . . . . . . . . . B5-9

5.7 REFERENCES ..................... B5-10

5.8 APPENDICES . . . . . . . . . . . . . . . . . . .

5.8.1 Listing of ORIGEN2 Input File for $875 \mathrm{~mL}$ of $\ldots$ Worst-Case Source Term . . . B5-11

5.8.2 Listing of MCNP Input File . . . . . . . . B5-12

6.0 CRITICALITY EVALUATION . . . . . . . . . . . . . . . B6-1

6.1 DISCUSSION AND RESULTS . . . . . . . . . . . . . . . B6-1

6.2 REFERENCES . . . . . . . . . . . . . . . . . . B6-1

7.0 STRUCTURAL EVALUATION $\ldots \ldots \ldots$. . . . . . . . . . . . B B

7.1 INTRODUCTION . . . . . . . . . . . . . . . . . . B7-1

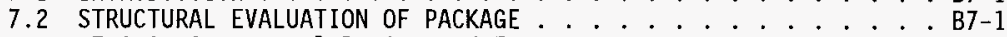

7.2.1 Structural Design and Features ........... B7-1

7.2.2 Mechanical Properties of Materials . . . . . . . B7-1

7.2.3 Chemical and Galvanic Reactions . . . . . . . . B B7-2

7.2.4 Size of Package and Cavity ............ B7-2

7.2.5 Weights and Centers of Gravity . . . . . . . . B7-2

7.2.6 Tamper Indicating Feature . . . . . . . . . . . B7-3

7.2 .7 Positive Closure . . . . . . . . . . . . B7-3

7.2.8 Lifting and Tiedown Devices . . . . . . . B7-3

7.2 .9 Brittle Fracture . . . . . . . . . . . B7-4

7.3 NORMAL TRANSFER CONDITIONS . . . . . . . . . . B7-4

7.3.1 Conditions to be Evaluated . . . . . . . . . . B7-4

7.3.2 Acceptance Criteria . . . . . . . . . . . . B7-4

7.3.3 Structural Model . . . . . . . . . . . . . . B7-5

7.3.4 Initial Conditions ............. . . B7-5

7.3.5 Structural Evaluations and Conclusions . . . . . . B7-6

7.4 ACCIDENT CONDITIONS ................... B7-6

7.4.1 Conditions to be Evaluated . . . . . . . . B7-6

7.4 .2 Acceptance Criteria . . . . . . . . . . . . B7-7

7.4.3 Structural Mode1 . . . . . . . . . . . . . . . B7-7

7.4 .4 Initial Conditions . . . . . . . . . . . B B

7.4.5 Structural Evaluation and Conclusions . . . . B7-7

7.5 REFERENCES . . . . . . . . . . . . . . B7-8

7.6 APPENDICES . . . . . . . . . . . . . . . . . B7-10

7.6.1 Design Calculations . . . . . . . . B7-10

7.6.2 Operating Instructions Change for $\mathrm{N}-55$ Overpack
Evaluation . . . . . . . . B $37-45$ 
HNF-SD-TP-SARP-023 Rev. 0

CONTENTS (cont)

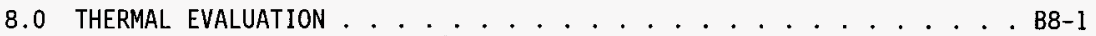

8.1 THERMAL SOURCE SPECIFICATION . . . . . . . . . . . . . . . . B8-1

8.2 SUMMARY OF THERMAL PROPERTIES . . . . . . . . . . . . . B8-1

8.2.1 Doorstop Container . . . . . . . . . . . B8-1

8.2.2 DOT 208-L Drum and Galvanized Steel Liner of 0verpack . . . . . . . . . . . . . B8-2

8.2 .3 Polystyrene . . . . . . . . . . . . . B8-2

8.2 .4 Polyurethane ............. . . B8-3

8.2.5 Fiberglass . . . . . . . . . . . . B8-3

8.2.6 Air . . . . . . . . . . . B8-3

8.2.7 Waste contents . . . . . . . B8-4

8.3 THERMAL EVALUATION FOR NORMAL CONDITIONS ......... B8-4

8.3.1 Acceptance Criteria . . . . . . . . . . . . B8-5

8.3.2 Therma1 Model for Normal Conditions . . . . . . B8-5

8.3.3 Thermal Analysis Results for Normal Conditions . . . B8-9

8.4 THERMAL EVALUATION FOR ACCIDENT CONDITIONS ...... B8-11

8.4.1 Acceptance Criteria . . . . . . . . . . . B8-11

8.4.2 Thermal Model for Accident Conditions ....... B8-11

8.4.3 Thermal Analysis Results for Accident Condition . B8-12

8.5 THERMAL EVALUATION CONCLUSION . . . . . . . . . . . B8-19

8.6 REFERENCES . . . . . . . . . . . . . . . . . . . B8-19

8.7 APPENDICES . . . . . . . . . . . . B8-21

8.7.1 Thermal Evaluation Model for Normal Condition . . B8-21

8.7.2 Thermal Evaluation Model for Accident Condition : B8-34

9.0 PRESSURE AND GAS GENERATION EVALUATION . . . . . . . . . . B9-1

9.1 GAS GENERATION . . . . . . . . . . . . . . . . . . . B9-1

9.2 PACKAGE PRESSURE . . . . . . . . . . . . . . B B9-1

9.3 APPENDICES . . . . . . . . . . . . . . . . . . . . . .

9.3.1 Hydrogen Gas Generation Calculations ....... . B9-2

9.3.2 Hydrogen Gas Generation in the Doorstop Container -

Addendum . . . . . . . . . . . . B9-15

10.0 PACKAGE TIEDOWN SYSTEM EVALUATION . . . . . . . . . . . . . B10-1

10.1 TIEDOWN EVALUATION ................. . . . B10-1

10.2 TIEDOWN DEVICES . . . . . . . . . . . . . . . . . . . Bl0-2

10.2.1 Acceleration Directional Loadings . . . . . . . . B10-2

10.2.2 Tiedown Frame Eyebolt . . . . . . . . . . . . B10-6

10.2.3 Stops Welded to Tiedown Frame . . . . . . . . . . Bl0-6

10.2.4 Tiedown Cables................ . B10-7

10.2.5 Tiedown Base . . . . . . . . . . . . . . . . . . . B10-7

10.2.6 Frame Tiedown Attachments . . . . . . . . . . B B10-7

10.2.7 Tiedown Base Frame. . . . . . . . . . . . . . . . . B10-9

10.2.8 Bolts . . . . . . . . . . . . . . . B B10-10

10.3 ATTACHMENTS AND RATINGS . . . . . . . . . . . . . . . . B10-11

10.4 REFERENCES . . . . . . . . . . . . B10-11 


$$
\text { HNF-SD-TP-SARP-023 Rev. } 0
$$

\section{LIST OF FIGURES}

A2-1 Doorstop Sample Carrier System Contents . . . . . . . . . . . . A2-2

A2-2 Doorstop Sample Carrier System . . . . . . . . . . . . . . A2-3

A4-1 Tiedown Configuration . . . . . . . . . . . . . . . A4-2

B5-1 Arrangement of the Doorstop Containers in the N-55 . . . . . . . B5-6

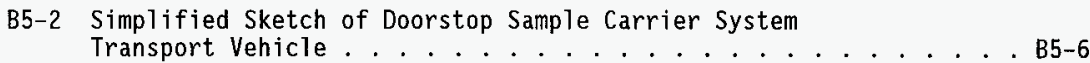

B8-1 General View of Thermal Evaluation Finite Element Mode1 . . . . B8-5

B8-2 Finite Element Model with Node Numbers (Right Side) . . . . . . . B8-6

B8-3 Right Side Zoom of Nodes . . . . . . . . . . . . . . . . B8-6

B8-4 Temperature Distribution of Normal Condition Case 1....... B8-10

B8-5 Temperature Distribution for Normal Condition Case 2 . . . . . B8-10

B8-6 Temperature Distribution for Normal Condition Case 3 . . . . B8-11

B8-7 Temperature Distribution for Accident Condition, Initial Steady State.................... B8-13

B8-8 Temperature Distribution for Accident Condition, Heat up to $800^{\circ} \mathrm{C}\left(1475^{\circ} \mathrm{F}\right)$......................... B8-13

B8-9 Temperature Distribution for Accident Condition, 10 minutes at $800{ }^{\circ} \mathrm{C}\left(1475^{\circ} \mathrm{F}\right)$. . . . . . . . . . . . . B8-14

B8-10 Temperature Distribution Accident Condition, 20 minutes at $800^{\circ} \mathrm{C}\left(1475^{\circ} \mathrm{F}\right)$.................... B 8 . . . . 14

B8-11 Temperature Distribution for Accident Condition, 30 minutes at $800^{\circ} \mathrm{C}\left(1475^{\circ} \mathrm{F}\right)$........................ B8 15

B8-12 Temperature Distribution for Accident Conditions, Cool Down to $46{ }^{\circ} \mathrm{C}\left(115^{\circ} \mathrm{F}\right)$. . . . . . . . . . . B8-15

B8-13 Temperature Distribution for Accident Condition, 30 minutes at $46{ }^{\circ} \mathrm{C}\left(115^{\circ} \mathrm{F}\right)$ after Fire Event ............. . B8-16

B8-14 Temperature Distribution for Accident Condition, $200 \mathrm{~h}$ at $46{ }^{\circ} \mathrm{C}$ $\left(115^{\circ} \mathrm{F}\right)$ after the Fire Event .............. B8-16

B8-15 Maximum Temperature History at the Container Seal . . . . . . . B8-17

B8-16 Maximum Temperature History at Exterior Wall of Overpack . . . B8-17 


$$
\text { HNF-SD-TP-SARP-023 Rev. } 0
$$

\section{LIST OF FIGURES (cont)}

B8-17 Maximum Temperature History at Interior Wall of Overpack . . . B8-18

B8-18 Maximum Temperature History at Exterior Wall of Inner Pack . . . B8-18

B10-1 Tiedown Assembly Dimensions . . . . . . . . . . . . . . . . B10-1

B10-2 Tiedown Dimensions, Plan View . . . . . . . . . . . . . . . . B10-2

B10-3 Transport Load Components . . . . . . . . . . . . . . . . B10-3

B10-4 Oblique Direction Dimensions ................. . . B10-5

B10-5 Tiedown Base Frame .. . . . . . . . . . . . . . . . . B10-10 
HNF-SD-TP-SARP-023 Rev. 0

\section{LIST OF TABLES}

A2-1 Doorstop Sample Carrier System Weights . . . . . . . . . . A2-5

A3-1 Solid Tank Waste Source Terms for the Doorstop . . . . . . . . . . A3-2

A4-1 External Package Contamination Limits . . . . . . . . . . . A4-3

A4-2 Gas Generation in $1.6-\mathrm{mL}, 20-\mathrm{mL}$, and $125-\mathrm{mL}$ Samples in the

Doorstop Container ................. A4-3

A4-3 Gas Generation Shipping Windows Limits Based on Concentration . . A4-4

A4-4 Nuclide Content ( $\mathrm{Ci} / \mathrm{L}$ by Case Number . . . . . . . . A4-5

A5-1 Quality Level A-3 Fabrication Testing and Inspections . . . . . A5-1

A5-2 Quality Level B-3 Fabrication Inspections and Tests . . . . . . A5-2

A5-3 Quality Level C-3 Fabrication Tests and Inspections . . . . . A5-2

A5-4 Quality Level A-3 Component Inspections ............ A5-3

A5-5 Quality Level B-3 Component Inspections ........... A5-3

A5-6 Quality Leve1 C-3 Component Inspections . . . . . . . . . A5-4

A7-1 Procurement and Fabrication Quality Levels . . . . . . . A7-4

A8-1 Quality Level A-3 Maintenance Requirements . . . . . . . . . A8-1

A8-2 Quality Level B-3 Maintenance Requirements . . . . . . . . . A8-1

A8-3 Quality Level C-3 Maintenance Requirements . . . . . . . A8-2

B2-1 Solid Tank Waste Source Terms for the Doorstop . . . . . . . B2-2

B2-2 Inner Packaging Normally Used in Doorstop Container . . . . . . B2-3

B5-1 Solid Tank Waste Source Terms for the Doorstop Sample Carrier System .................... . . B5-2

B5-2 Photon Emission Rates (Photons/s) for the Doorstop Sample Carrier System ..................... B5-3

B5-3 Photon Fluence-to-dose Conversion Factors . . . . . . . . . B5-5

B5-4 Doorstop Sample Carrier System Radial Geometry and Material Composition ................. . B5-7

B5-5 Doorstop Sample Carrier System Axial Geometry and Material Composition ................. . . B5-7 
HNF-SD-TP-SARP-023 Rev. 0

\section{LIST OF TABLES (cont)}

B5-6 Dose Rates Outside the Doorstop Sample Carrier System, mSv/h $(\mathrm{mrem} / \mathrm{h})$..................... B5-8

B5-7 Comparison of Maximum Dose Rates, mSv/h (mrem/h), with Dose Rate Limits .. . . . . . . . . . . . . . . . . B5-10

B6-1 Doorstop Sample Carrier System Fissile Inventory . . . . . . . B6-1

B7-1 Mechanical Properties of Materials . . . . . . . . . . . . . B7-2

B7-2 Doorstop Sample Carrier System Weights . . . . . . . . . . . . B7-3

B8-1 Material Properties of 304 Stainless Steel . . . . . . . . . . B8-2

B8-2 Material Properties of Mild Carbon Steel . . . . . . . . . . . B8-2

B8-3 Material Properties of Air . . . . . . . . . . . . . . . B8-4

B8-4 Convection Heat Transfer Coefficient of Air Ambient Temperature at $46{ }^{\circ} \mathrm{C}\left(115^{\circ} \mathrm{F}\right)$. . . . . . . . . . . . B8-8

B8-5 Convection Heat Transfer Coefficient of Air Ambient Temperature at $-40^{\circ} \mathrm{C}\left(-40^{\circ} \mathrm{F}\right)$....................... B8-8

B8-6 Case 2 Replacement . . . . . . . . . . . . . . . . . . B8-9

B8-7 Normal Condition Thermal Analysis Results Maximum Temperature Except Indicated by Min . . . . . . . . . . . . . . B8-9

B8-8 Convection Heat Transfer Coefficient of Air Ambient Temperature at $800^{\circ} \mathrm{C}\left(1475{ }^{\circ} \mathrm{F}\right)$................. B . . . . . . 8 . 12

B8-9 Fire Accident Thermal Analysis Results ... . . . . . . . . . B8-19

B9-1 Gas Generation in $875 \mathrm{~mL}(29.6 \mathrm{oz})$ Samples in the Doorstop Sample Carrier System . . . . . . . . . . . . . . . . B9-1 


\section{LIST OF TERMS}

$\begin{array}{ll}\text { AISC } & \text { American Institute of Steel Construction } \\ \text { ANSI } & \text { American National Standards Institute } \\ \text { ASME } & \text { American Society of Mechanical Engineers } \\ \text { ASTM } & \text { American Society for Testing and Materials } \\ \text { AWS } & \text { American Welding Society } \\ \text { BPVC } & \text { Boiler and Pressure Vessel Code } \\ \text { CFR } & \text { Code of Federal Regulations } \\ \text { Ci } & \text { curie } \\ \text { Ci/L } & \text { curies per liter } \\ \text { Cm } & \text { centimeter } \\ \text { DOT } & \text { U.S. Department of Transportation } \\ \text { ft } & \text { feet } \\ \text { in. } & \text { inch } \\ \text { kg } & \text { kilogram } \\ \text { Ib } & \text { pound } \\ \text { m } & \text { meter } \\ \text { mL } & \text { milliliter } \\ \text { mrem } / h & \text { millirem per hour } \\ \text { mSV } / \mathrm{h} & \text { millisievert per hour } \\ \text { NRC } & \text { U.S. Nuclear Regulatory Commission } \\ \text { NuPac } & \text { Nuclear Packaging, Incorporated } \\ \text { OD } & \text { outside diameter } \\ \text { OTC } & \text { Onsite Transfer Cask } \\ \text { OZ } & \text { ounce } \\ \text { PQS } & \text { Procurement Quality Support } \\ \text { QA } & \text { quality assurance } \\ \text { QC } & \text { Quality Control } \\ \text { QL } & \text { Quality Level } \\ \text { PQS } & \text { Procurement Quality Support } \\ \text { SARP } & \text { safety analysis report for packaging } \\ \text { SS } & \text { stainless steel } \\ \text { THI } & \text { Transportation Hazard Indicator } \\ \text { USQ } & \text { unresolved safety question } \\ \text { WHC } & \text { Westinghouse Hanford Company } \\ & \end{array}$


HNF-SD-TP-SARP-023 Rev. 0

\section{SAFETY ANALYSIS REPORT FOR PACKAGING (ONSITE) DOORSTOP SAMPLE CARRIER SYSTEM}

\section{PART A: PACKAGE DESCRIPTION AND OPERATIONS}

\subsection{INTRODUCTION}

\subsection{GENERAL INFORMATION}

The Doorstop Sample Carrier System consists of a Type B certified N-55 overpack, U.S. Department of Transportation (DOT) specification or performance-oriented 208-L (55-gal) drum (D0T 208-L drum), and Doorstop containers. Up to seven Doorstop containers may be placed inside the DOT 208-L drum. The contents are packaged in several configurations inside the Doorstop containers: within a lead pak cylinder, within a slip lid can, food pack can, or paint can, or within sample pipettes inside the Doorstop sample carrier. Two Doorstop Sample Carrier Systems may be carried on the transport vehicle. The purpose of the Doorstop Sample Carrier System is to transport samples onsite for characterization. The package is authorized to transport tank farm solid, slurry, or liquid 125-mL (4.3-fl oz) samples or less per Doorstop container. The Doorstop Sample Carrier system is limited to $875 \mathrm{~mL}$ (29.6 fl oz).

This safety analysis report for packaging (SARP) provides the analyses and evaluation necessary to demonstrate that the Doorstop Sample Carrier System meets the requirements and acceptance criteria for both Hanford Site normal transport conditions and accident condition events for a Type $B$ package. This SARP also establishes operational, acceptance, maintenance, and quality assurance (QA) guidelines to ensure that the method of transport for the Doorstop Sample Carrier System is performed safely in accordance with WHC-CM-2-14, Hazardous Material Packaging and Shipping.

The packaging meets a 11 WHC-CM-2-14 requirements of a Transportation Hazard Indicator (THI) 3 performance packaging for the Hanford Site. Evaluation by analysis and fabrication leak testing per American National Standards Institute (ANSI) N14.5 (ANSI 1987) demonstrates packaging performance and safety. Onsite approval for shipment is based on the performance qualifications of the $\mathrm{N}-55$ overpack, performing a drop test structural comparison to the Sample Pig Shipping Container (which also uses the $\mathrm{N}-55$ Overpack System), and performing structural analysis on the Doorstop containers.

\subsection{SYSTEM DESCRIPTION}

The Doorstop Sample Carrier System is an onsite, interarea packaging for transferring Type $B$ radioactive material on the Hanford Site in accordance 
with WHC-CM-2-14. The analyses and evaluations performed in this SARP demonstrate that this packaging complies with the onsite transportation safety criteria.

The Doorstop Sample Carrier System consists of a Type B certified N-55 overpack, a DOT 208-L drum, and the content containers. The $\mathrm{N}-55$ overpack is manufactured by VECTRA Technologies, Inc (VECTRA). The overpack is a right circular cylinder consisting of two parts. Closure of the upper and lower ( 1 id and body) sections of the overpack is provided by four toggle clamps and a Neoprene gasket at the stepped joint between the two sections. The $\mathrm{N}-55$ overpack carries a Certificate of Compliance (CoC [USA/9070/B(U)]) (NRC 1994). This approval constitutes authority to use the package for the shipment of solid or dry radioactive material. The contents of the Doorstop Sample Carrier system also include liquid samples. As the certificate does not apply to the liquid contents, it is necessary to demonstrate that the Doorstop Sample Carrier System maintains containment of the contents to meet the onsite packaging safety criteria.

The N-55 overpack has been built for years. Nuclear Packaging, Inc. (NuPac) produced the initial overpack design certified by the U.S. Nuclear Regulatory Commission (NRC), CoC USA $/ 9070 / B(U)$. Over the years, minor changes were made to the overpack design. The changes in the overpack design were reflected in the request for certification submittals to the NRC. In 1994, the package design was transferred to VECTRA. The current CoC USA/9070/B(U), Rev. 12, is held by VECTRA. For onsite use, overpacks built for NuPac, VECTRA, or other authorized companies may be used. The overpacks built to any of the designs covered by the revision of the certification are authorized for use under this SARP.

The second packaging component is a DOT 208-L drum (stainless steel or gaivanized). The drum 7 id contains a $0.95-\mathrm{cm}\left(\% / \mathrm{s}-\mathrm{in}\right.$.) tubular NEOZAN ${ }^{2}$ gasket. The space inside the drum is occupied by three separate sections of expanded polystyrene beadboard. A layer of plywood over the bottom beadboard provides a base on which the Doorstop containers rest. The second layer of beadboard has seven cavities sized to fit Doorstop containers. The third solid section of beadboard with a plywood face fills the rim.

The third packaging component is the Doorstop container ( $\mathrm{H}-2-73008)$, which is considered to be the package containment boundary. The Doorstop container is a similar design to the DOT Specification $2 R$ container. A handle is attached to the lid to permit handling manually or by hoist. The containers are serially numbered by metal impression stamping on the lid and the body. Absorbent material is placed inside the container to absorb twice the amount of liquid in the event of a spill.

The fourth packaging component is the Doorstop sample carrier (see Figure A2-1). The Doorstop sample carriers are built to two designs. One design is constructed of 304-L stainless steel American Society for Testing and Materials (ASTM) A-240. A second design is constructed of 304-L stainless

\footnotetext{
${ }^{1}$ Neoprene is a trademark of E. I. du Pont de Nemours and Company.

2 NEOZAN is a trademark of Self Industries.
} 
steel A-240 and lead. The Doorstop sample carriers are serially numbered by metal impression stamping on the top face of the body portion. The Doorstop sample carriers with a number only are stainless steel units. The lead-lined Doorstop sample carriers have the letter " $L$ " immediately following the number. Two, $0.159-\mathrm{cm}-(1 / 16-i n .-)$ deep grooves have been machined into the cylindrical surface of the body of the lead-lined Doorstops for identification purposes. The individual samples are placed into polyethylene pipettes. The pipettes are then placed into a Doorstop sample carrier insert, and then the Doorstop sample carrier is placed inside the Doorstop container.

The Doorstop container may also be used as a packaging for larger liquid samples. These samples are contained in polyethylene or glass bottles with screw lids. The bottles are placed in a polyethylene bag and sealed (tape or heat sealed). The bagged sample bottles are placed inside a slip lid, food pack can, or paint can; filled with absorbent (noncellulosic inert absorbent); sealed with a wrap of tape; and loaded into the Doorstop container, which is then screwed shut.

There is an additional configuration of the Doorstop container that may be used for shipment of waste tank samples. A vial containing the sample is placed into a lead pak cylinder, which is placed into a slip lid can that is inside the Doorstop container.

\subsection{REVIEW AND UPDATE CYCLES}

This SARP is subject to periodic reviews and updates. The reviews shall be performed every five years to ensure that all SARP evaluations and other included information meet new or revised regulatory and/or company requirements. The first complete review and update of the Doorstop Sample Carrier System SARP will be approximately February 2002. Review sha11 be through the formal process per Part A, Section 7.5. 
HNF-SD-TP-SARP-023 Rev. 0

This page intentionally left blank.

Al-4 
HNF-SD-TP-SARP-023 Rev. 0

\subsection{PACKAGING SYSTEM}

\subsection{CONFIGURATION AND DIMENSIONS}

The Doorstop Sample Carrier System has a maximum gross weight of approximately $324 \mathrm{~kg}(715 \mathrm{lb})$. See Figures A2-1 and A2-2.

The N-55 overpack is a right circular cylinder $122 \mathrm{~cm}$ (48 in.) high by $81 \mathrm{~cm}$ (32 in.) in diameter with a 89-cm- (35-in.-) high by 61-cm- (24-in.-) diameter cavity. The overpack acts as an impact 1 imiter and thermal shield for the Doorstop Sample Carrier System. The overpack shell is constructed of 1 -mm (20-gauge) galvanized steel filled with $48.1 \mathrm{~kg} / \mathrm{m}^{3}\left(3 \mathrm{lb} / \mathrm{ft}^{3}\right)$ rigid polyurethane foam. The packaging component, which is placed within the $\mathrm{N}-55$ overpack, is a DOT 208-L drum with dimensions of $89 \mathrm{~cm}$ (35 in.) high and $61 \mathrm{~cm}$ (24 in.) in diameter. The steel drum must have a minimum wall thickness of $1.3 \mathrm{~mm}$ (18 gauge), with a minimum $1.9-\mathrm{mm}$ (14-gauge) steel 1 id. Closure of the drum is by way of a $2.7-\mathrm{mm}$ (12-gauge) locking ring with drop-forged lugs and a $1.59-\mathrm{cm}-(5 / 8-i n .-)$ diameter bolt and lock nut.

The third packaging component which fits inside the DOT 208-L drum, is the Doorstop container. The Doorstop container is similar to a DOT 2R container and is $28.91 \mathrm{~cm}$ (11.38 in.) tall by $16.21 \mathrm{~cm}$ (6.38 in.) in diameter. The Doorstop container weighs approximately $14.5 \mathrm{~kg}(32 \mathrm{lb})$. The upper end of the Doorstop container is faced, threaded, and machined to provide for an 0 -ring seal (see Figure $A 2-1$ ).

The Doorstop sample carriers, which are placed within the Doorstop container, are built to two designs. One design, approximately $12.7 \mathrm{~kg}$ (28 $\mathrm{lb}$ ) is constructed of 304-L stainless steel A-240. A second design, approximately $14.5 \mathrm{~kg}(32 \mathrm{1b})$, is constructed of $304-\mathrm{L}$ stainless steel A-240 and lead. The base portion of both Doorstop sample carrier designs (stainless steel and lead lined) are $11.4 \mathrm{~cm}(4.5 \mathrm{in.})$ in diameter and $14.3 \mathrm{~cm}$ ( $5.625 \mathrm{in.}$ ) high. The individual samples are placed into polyethylene pipettes, which come in three sizes: $0.5 \mathrm{~mL}, 1.0 \mathrm{~mL}$, and $1.6 \mathrm{~mL}$. The pipette is placed into a Doorstop sample carrier insert positioned into a hole $5 \mathrm{~cm}$ (2 in.) in diameter by $4.3 \mathrm{~cm}$ (1.625 in.) in depth in the Doorstop sample carrier body. A lead-filled plug is lowered over the Doorstop sample carrier insert. The lower face of the Doorstop sample carrier plug is designed with a $3.8-\mathrm{cm}-(1.5-i n .-)$ diameter by $0.318-\mathrm{cm}-(0.125-\mathrm{in} .-)$ deep recess into which a $3.8-\mathrm{cm}-(1.5-i n .-)$ diameter by $0.64-\mathrm{cm}-(0.25-$ in.-) $)$ thick gasket of 20 durometer Neoprene ${ }^{3}$ rubber is placed. The Doorstop sample carrier handle (yoke) is notched at each end and mounts on the two side-mounted bolts. The yoke contains a special handle stud assembly. The stud consists of a $0.953-\mathrm{cm}$ (0.375-in.) hex head bolt that has been modified by welding a $1.27-\mathrm{cm}$ (0.5-in.) wing nut to the bolt forming a wing nut bolt. The bolt has also been modified by welding a $1.9-\mathrm{cm}^{-}(0.75-\mathrm{in.-})$ diameter by $0.953-\mathrm{cm}-$ $(0.375$-in.-) long rod to the bottom. When the plug is lowered into the cavity and the handle is attached, the wing nut and rod apply pressure on the top surface of the plug, compressing the rubber gasket against the face of the

3 Neoprene is a trademark of E. I. du Pont de Nemours and Company. 
Figure A2-1. Doorstop Sample Carrier System Contents.

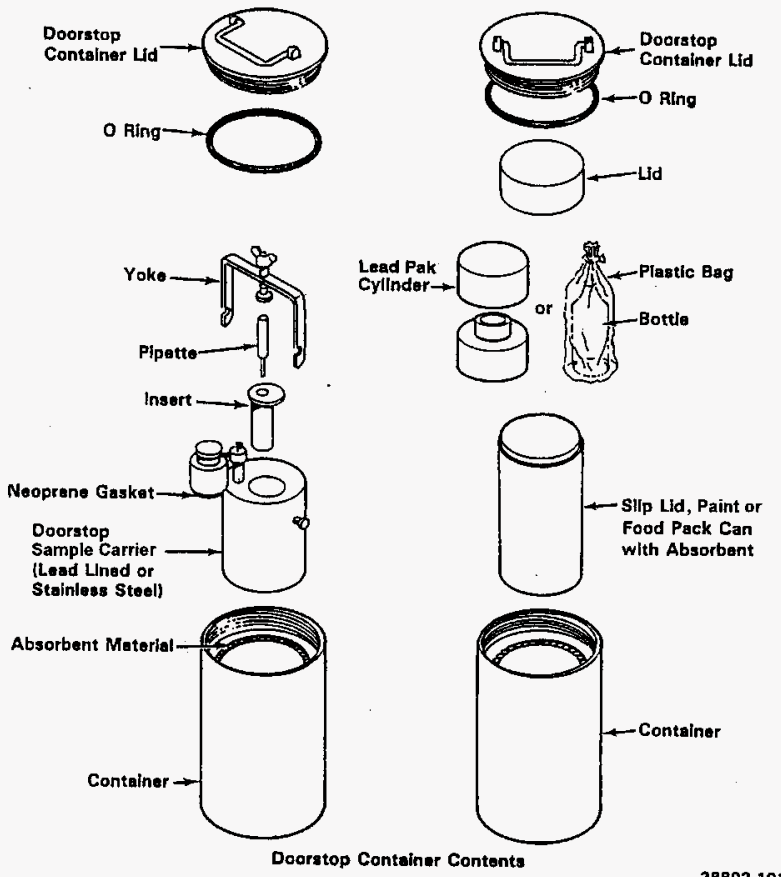


HNF-SD-TP-SARP-023 Rev. 0

Figure A2-2. Doorstop Sample Carrier System.

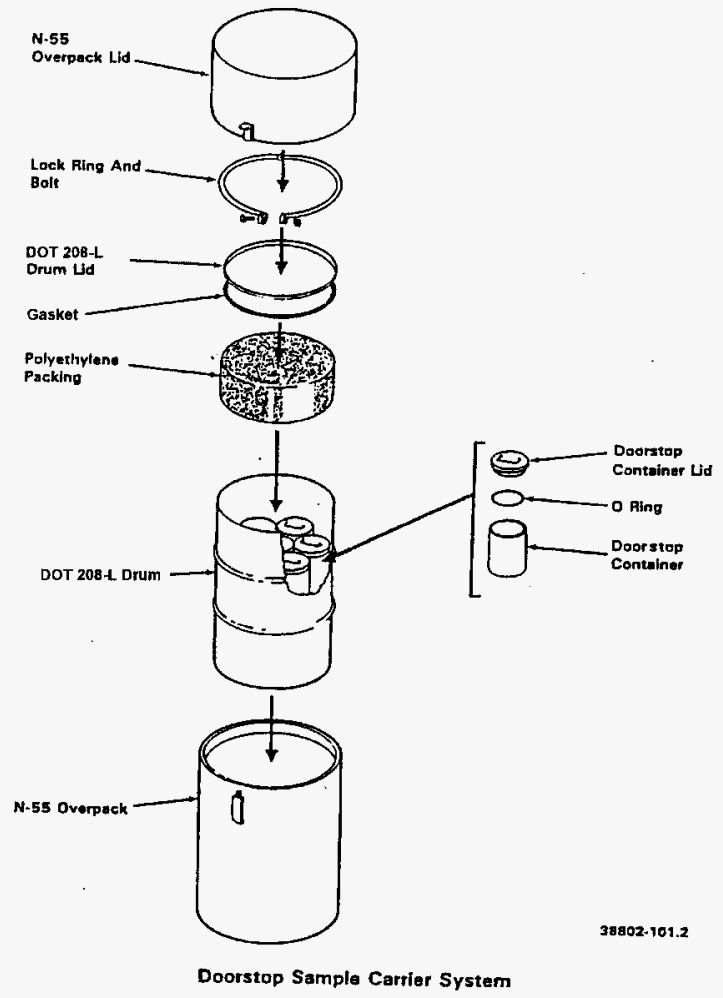


HNF-SD-TP-SARP-023 Rev. 0

styrene insert and providing a seal to hold the liquid sample inside the insert. The rubber gasket is sandwiched between the plug and the plastic insert.

A lead pak cylinder is another configuration that can be placed in the Doorstop container for shipments of waste tank samples. The lead cylinder is approximately $13 \mathrm{~cm}$ (5.125 in.) in height with a $8.3-\mathrm{cm}(3.25-$ in.) outside diameter. The inner cavity of the lead cylinder is approximately $8.9 \mathrm{~cm}$ ( $3.5 \mathrm{in.}$ ) by $3.18 \mathrm{~cm}$ (1.25 in.). The cylinder weighs approximately $6.6 \mathrm{~kg}$ $(14.5 \mathrm{~Tb})$. The lead walls of the cylinder are $2.54 \mathrm{~cm}$ (1 in.) thick on the sides and the bottom of the cavity and $1.6 \mathrm{~cm}(0.625 \mathrm{in.})$ thick on the top of the cavity.

\subsection{MATERIALS OF CONSTRUCTION} follows:

The structural materials for the Doorstop Sample Carrier System are as

- N-55 overpack: 1-mm (20-gauge) galvanized steel and $48.1 \mathrm{~kg} / \mathrm{m}^{3}$ ( $3 \mathrm{lb} / \mathrm{ft}^{3}$ ) rigid polyurethane foam per NuPac Specification No. $X-60-N 55 F$

- DOT 208-L drum: stainless or galvanized carbon steel

- Doorstop container: 304-L seamless stainless steel pipe

- Doorstop sample carrier: lead 1ined and/or 304-L stainless steel

- Lead pak cylinder: lead.

Other materials utilized are:

- Overpack fiberglass molded inner shell

- Overpack expanded honeycomb Type KPl/2 80(11)E, Type HNC $3 / 4$ $80(16)$ E or equal

- NEOZAN gasket on the drum

- Expanded polystyrene beadboard and plywood

- Neoprene O-ring on the Doorstop container.

\subsection{MECHANICAL PROPERTIES OF MATERIAL}

The mechanical material properties for the Doorstop Sample Carrier System are presented in Part B, Section 7.2.2. 
HNF-SD-TP-SARP-023 Rev. 0

\subsection{DESIGN AND FABRICATION METHODS}

Design, fabrication, and testing of the Doorstop containment boundary were performed per the requirements of the American Society of Mechanical Engineers (ASME) Boiler and Pressure Vessel Code (BPVC), Section VIII (ASME 1995). Based on Regulatory Guide 7.11, Table 1 (NRC 1991), the Doorstop system is Category III. The containment boundary design follows the criteria from ASME BPVC, Section VIII. The structural analyses criteria meets ASME $B P V C$, Section VIII, requirements.

Al1 welders are required to be qualified per ASME, Section IX (ASME 1995). The containment weld is dye penetrant and visually inspected. During fabrication, welds are made sufficiently rounded to enable easy decontamination.

During fabrication, inspections and containment leak testing of the Doorstop are performed per Hanford Site procedures and ANSI N14.5 (ANSI 1987), respectively.

\subsection{WEIGHTS AND CENTER OF GRAVITY}

The weight of the packagings that makes up the Doorstop Sample Carrier System and the total weight are shown in Table A2-1. The total weight of the Doorstop Sample Carrier System with seven Doorstops is $324 \mathrm{~kg}$ (715 1b) with center of gravity located on the vertical centerline of the packaging $55.3 \mathrm{~cm}$ (21.78 in.) from the bottom.

Table A2-1. Doorstop Sample Carrier System Weights.

\begin{tabular}{|l|c|}
\hline \multicolumn{1}{|c|}{ Component } & $\begin{array}{c}\text { Weight } \\
\mathrm{kg} \text { (Ib) }\end{array}$ \\
\hline \hline Overpack & $90.7(200)$ \\
\hline Drum with padding & $30.4(67)$ \\
\hline Doorstop containers (seven) & $101.6(224)$ \\
\hline Doorstops (seven) & $101.6(224)$ \\
\hline \hline Total & $324(715)$ \\
\hline
\end{tabular}

\subsection{CONTAINMENT BOUNDARY}

The Doorstop container provides the containment boundary. The containment boundary consists of the following items as shown on Figure A2-1:

- Doorstop container closure lid

- Doorstop container body.

The closure lid is threaded with and has an 0-ring gasket, which provides a seal. The containment boundary meets the definition of leaktight given in 
HNF-SD-TP-SARP-023 Rev. 0

ANSI N14.5 (ANSI 1987). The DOT 208-L drum provides a secondary containment boundary with its gasket and bolted lid. For a complete description of the containment system, refer to Part B, Section 4.0.

The containment boundary meets the required leak rate of $5.81 \times 10^{-5} \mathrm{std}-\mathrm{cc} / \mathrm{s}$, air, as required by the $A_{2}$ value of the radionuclide contents shown in Part B, Section 4.0.

\subsection{CAVITY SIZE}

The Doorstop container cavity size is $22.56 \mathrm{~cm}(8.88 \mathrm{in.})$ in height by $14 \mathrm{~cm}$ ( $5.5 \mathrm{in.})$ in diameter.

\subsection{HEAT DISSIPATION}

No special devices are used for the transfer or dissipation of heat. Refer to Part B, Section 8.0, for the thermal evaluation of the Doorstop Sample Carrier System. Maximum allowable decay heat is $3 \mathrm{~W}$ per Doorstop Sample Carrier System. Heat is dissipated passively.

\subsection{SHIELDING}

Radiation shielding is provided based on the contents of the Doorstop Sample Carrier System. The walls of the Doorstop container are stainless steel. The shielding provided inside the Doorstop container is lead, stainless steel, or a combination of both. The lead pak is a solid lead cylinder. The Doorstop sample carrier is constructed of either solid stainless steel or stainless steel clad lead. Refer to Part B, Section 5.0, for the shielding evaluation.

\subsection{LIFTING DEVICES}

The lifting device for the $\mathrm{N}-55$ overpack lid consists of a lifting beam that is attached to the N-55 1 id via four J-bolts.

The lifting device for the Doorstop container consists of a handle that is attached to the 1id. The handle permits handling manually or by hoist.

The lifting device for the Doorstop sample carriers consists of a lifting yoke, which is notched at each end and mounts on the two side mounted bolts. The yoke contains a special handle stud assembly.

\subsection{TIEDOWN DEVICES}

There are no tiedown devices that are a structural part of the package. Therefore, the 49 CFR 173 requirements of $10 \mathrm{~g}, 5 \mathrm{~g}$, and $2 \mathrm{~g}$ are not required to be met or analyzed. 
HNF-SD-TP-SARP-023 ReV. 0

\subsection{PACKAGE CONTENTS}

\subsection{GENERAL DESCRIPTION}

The Doorstop Sample Carrier System is used to transport liquid or solid samples. The solid radionuclide composition that bounds the liquid tank waste for all areas considered in this SARP is from WHC-SD-WM-SARR-016 (WHC 1996); i.e., shielding, dose consequence, thermal, gas generation, criticality. Therefore, as shown in Part B, Section 2.0, the source terms were established using the solid tank waste activity concentrations. Two different source terms were evaluated in the shielding section. These source terms were identified as $875 \mathrm{~mL}(29.6 \mathrm{fl} \mathrm{oz})$ of the maximum expected source term and $875 \mathrm{~mL}(29.6 \mathrm{fl} \mathrm{oz})$ worst-case source term. The worst-case source term was developed by first determining the maximum activity concentration of each radionuclide using the existing sample data from all of the tanks. These activity concentrations were assumed to exist in a single tank, thus creating a worst-case source term. Consequently, it is not possible to have a sample that contains all of the maximum radionuclide quantities because they are from several different tanks. Historically, the dose rates on the surface of the Doorstop Sample Carrier System have been less than $2 \mathrm{mSv} / \mathrm{h}$ (200 $\mathrm{mrem} / \mathrm{h})$. Therefore, a second "maximum expected" source term was developed based on a $2 \mathrm{mSv} / \mathrm{h}(200 \mathrm{mrem} / \mathrm{h})$ dose rate at the $\mathrm{N}-55$ overpack surface. The shielding section focuses on $875 \mathrm{~mL}(29.6 \mathrm{fl}$ 0z) of the maximum expected source term and $875 \mathrm{~mL}(29.6 \mathrm{fl} \mathrm{oz})$ of the worst-case source term since these two source terms are bounding from a radioactive inventory standpoint.

Table A3-1 shows the worst-case and maximum expected solid tank waste activity concentrations along with the radioactive inventory for these two source terms. Note that all other loads result in a smaller volume of radioactive material and in most cases additional packaging components that provide more shielding.

The heat generation rate for $875 \mathrm{~mL}(29.6 \mathrm{fl} \mathrm{oz})$ of the worst-case source term is $4.9 \times 10^{-1} \mathrm{~W}$, as can be seen in the gas generation analys is in Part $B$, Section 9.0. The $875 \mathrm{~mL}(29.6 \mathrm{fl} \mathrm{oz})$ of the maximum expected source term corresponds to $5.0 \mathrm{~A}_{2} \mathrm{~s}$, and $875 \mathrm{~mL}(29.6 \mathrm{fl} \mathrm{oz})$ of the worst-case source term contains $93 \mathrm{~A}_{2} \mathrm{~s}$ as shown in Table $\mathrm{B} 3-1$. Therefore, the package is authorized to transport Type $B$ quantities of radioactive material.

Fissile material is less than $15 \mathrm{~g}$ based on $875 \mathrm{~mL}(29.6 \mathrm{fl} \mathrm{oz})$ of the maximum expected source term and $875 \mathrm{~mL}(29.6 \mathrm{fl} \mathrm{oz})$ of the worst-case source term. Therefore, all shipments of the Doorstop Sample Carrier System are exempt from fissile material classification (10 CFR 71.53).

The package is authorized for up to $875 \mathrm{~mL}(29.6 \mathrm{fl}$ oz) of the maximum expected source term and $875 \mathrm{~mL}(29.6 \mathrm{fl} \mathrm{oz})$ of the worst-case source term. The chemical forms of authorized contents are water, hydrogen peroxide, sodium hydroxide, sodium nitrate, tri-butyl phosphate, normal paraffin hydrocarbon, and nitric acid. 
Table A3-1. Solid Tank Waste Source Terms for the Doorstop.

\begin{tabular}{|c|c|c|c|c|c|c|c|c|}
\hline Nucl ide & $\begin{array}{c}\text { Worst-case } \\
\text { solids } \\
\text { activity } \\
\text { concentration } \\
\text { (Ci/L) } \\
\end{array}$ & $A_{2}(C i)^{a}$ & $\begin{array}{r}875 \mathrm{~mL} \\
(29.6 \mathrm{oz}) \\
\text { maximumb } \\
\text { expected } \\
(\mathrm{Bq}) \\
\end{array}$ & $\begin{array}{c}875 \mathrm{~mL} \\
(29.6 \mathrm{oz}) \\
\text { maximum, } \\
\text { expected } \\
\text { (Ci) } \\
\end{array}$ & $A_{2} s$ & $\begin{array}{c}875 \mathrm{~mL} \\
(29.6 \mathrm{oz}) \\
\text { worst case } \\
\text { (Bq) }\end{array}$ & $\begin{array}{c}875 \mathrm{~mL} \\
(29.6 \text { oz }) \\
\text { worst case } \\
\text { (Ci) }\end{array}$ & $A_{2} s$ \\
\hline${ }^{14} \mathrm{C}$ & 4.3 E-06 & $5.4 E+01$ & $7.4 E+03$ & $2.0 \mathrm{E}-07$ & 3.7 E-09 & $1.4 E+05$ & $3.8 \mathrm{E}-06$ & $7.0 \mathrm{E}-08$ \\
\hline${ }^{60} \mathrm{Co}$ & $1.3 \mathrm{E}-02$ & $1.1 \mathrm{E}+01$ & $2.3 \mathrm{E}+07$ & $6.1 \mathrm{E}-04$ & 5.7 E-05 & $4.1 E+08$ & $1.1 \mathrm{E}-02$ & $1.0 \varepsilon-03$ \\
\hline${ }^{79} \mathrm{Se}$ & 4.6 E- 07 & $5.4 E+01$ & $8.1 E+02$ & 2.2 E- 08 & $4.1 E-10$ & $1.5 E+04$ & $4.0 \mathrm{E}-07$ & 7.4 E- 09 \\
\hline $90_{\mathrm{Sr}}$ & $7.8 \mathrm{E}+01$ & $2.7 \mathrm{E}+00$ & $1.4 \mathrm{E}+11$ & $3.7 E+00$ & $1.4 E+00$ & $2.5 \mathrm{E}+12$ & $6.8 E+01$ & $2.5 E+01$ \\
\hline $90 Y^{4}$ & $7.8 \mathrm{E}+01$ & $5.4 E+00$ & $1.4 E+11$ & $3.7 \mathrm{E}+00$ & 0.0 & $2.5 E+12$ & $6.8 E+01$ & 0.0 \\
\hline${ }^{99} \mathrm{TC}$ & 3.2 E-01 & $2.4 E+01$ & $5.6 E+08$ & $1.5 \mathrm{E}-02$ & 6.2 E-04 & $1.0 E+10$ & $2.8 E-01$ & $1.2 \mathrm{E}-02$ \\
\hline${ }^{106_{\mathrm{Ru}}}$ & $1.9 \mathrm{E}-06$ & $5.4 \mathrm{E}+00$ & $3.3 \mathrm{E}+03$ & 8.9 E-08 & 1.7 E-08 & $6.3 \mathrm{E}+04$ & $1.7 \mathrm{E}-06$ & $3.1 \mathrm{E}-07$ \\
\hline${ }^{106} \mathrm{Rh}^{\mathrm{f}}$ & $1.9 \mathrm{E}-06$ & 0.0 & $3.3 \mathrm{E}+03$ & $8.9 \mathrm{E}-08$ & 0.0 & $6.3 \mathrm{E}+04$ & $1.7 \mathrm{E}-06$ & 0.0 \\
\hline $125_{\mathrm{Sb}}$ & $4.9 E-03$ & $2.4 E+01$ & $8.5 \mathrm{E}+06$ & $2.3 E-04$ & $9.5 \mathrm{E}-06$ & $1.6 E+08$ & $4.3 E-03$ & $1.8 \mathrm{E}-04$ \\
\hline${ }^{129}{ }_{I}$ & 1.7 E-04 & Unl imited & $3.0 \mathrm{E}+05$ & $8.0 \mathrm{E}-06$ & 0.0 & $5.6 E+06$ & $1.5 \mathrm{E}-04$ & 0.0 \\
\hline${ }^{134} \mathrm{cs}$ & 2.5 E-04 & $1.4 \mathrm{E}+01$ & $4.4 E+05$ & $1.2 E-05$ & $8.9 \mathrm{E}-07$ & $8.1 E+06$ & 2.2 E- 04 & $1.6 \mathrm{E}-05$ \\
\hline $137 \mathrm{cs}$ & $2.7 \mathrm{E}+00$ & $1.4 E+01$ & $4.8 \mathrm{E}+09$ & $1.3 \mathrm{E}-01$ & $9.6 \mathrm{E}-03$ & $8.9 E+10$ & $2.4 \mathrm{E}+00$ & $1.8 \mathrm{E}-01$ \\
\hline $137 \mathrm{~m}_{\mathrm{Ba}}{ }^{f}$ & $2.6 E+00$ & 0.0 & $4.4 E+09$ & 1.2 E-01 & 0.0 & $8.5 E+10$ & $2.3 \mathrm{E}+00$ & 0.0 \\
\hline${ }^{144} \mathrm{Ce}$ & $9.2 \varepsilon-09$ & $5.4 \mathrm{E}+00$ & $1.6 \mathrm{E}+01$ & $4.3 \mathrm{E}-10$ & $8.0 \mathrm{E}-11$ & $3.0 \mathrm{E}+02$ & 8.1 E-09 & $1.5 \mathrm{E}-09$ \\
\hline${ }^{144} \mathrm{pr}^{f}$ & $9.2 \mathrm{E}-09$ & 0.0 & $1.6 \mathrm{E}+01$ & $4.3 \mathrm{E}-10$ & 0.0 & $3.0 \mathrm{E}+02$ & $8.1 \mathrm{E}-09$ & 0.0 \\
\hline${ }^{154} \mathrm{Eu}$ & $3.0 \mathrm{E}-01$ & $1.4 E+01$ & $5.2 E+08$ & $1.4 \mathrm{E}-02$ & $1.0 \mathrm{E}-03$ & $9.6 E+09$ & $2.6 \mathrm{E}-01$ & $1.9 \mathrm{E}-02$ \\
\hline $155_{\mathrm{Eu}}$ & $1.4 E-04$ & $5.4 \mathrm{E}+01$ & $2.4 E+05$ & $6.6 \mathrm{E}-06$ & $1.2 \mathrm{E}-07$ & $4.4 E+06$ & $1.2 \mathrm{E}-04$ & $2.2 \mathrm{E}-06$ \\
\hline $237 \mathrm{~Np}$ & $2.7 \mathrm{E}-02$ & $5.4 \mathrm{E}-03$ & $4.8 \mathrm{E}+07$ & $1.3 \mathrm{E}-03$ & $2.4 \mathrm{E}-01$ & $8.9 E+08$ & $2.4 \mathrm{E}-02$ & $4.4 E+00$ \\
\hline${ }^{238} \mathrm{Pu}$ & $5.1 E-03$ & $5.4 E-03$ & $8.9 \mathrm{E}+06$ & 2.4 E-04 & $4.4 E-02$ & $1.7 \mathrm{E}+0 \mathrm{~B}$ & 4.5 E- 03 & $8.3 \mathrm{E}-01$ \\
\hline${ }^{239} \mathrm{Pu}$ & $4.3 E-02$ & $5.4 E-03$ & $7.4 \mathrm{E}+07$ & $2.0 \mathrm{E}-03$ & 3.7 E- 01 & $1.4 E+09$ & $3.8 \mathrm{E}-02$ & $7.0 \mathrm{E}+00$ \\
\hline${ }^{240} \mathrm{Pu}$ & $4.3 \mathrm{E}-02$ & $5.4 \mathrm{E}-03$ & $7.4 E+07$ & $2.0 \mathrm{E}-03$ & $3.7 \mathrm{E}-01$ & $1.4 E+09$ & $3.8 \mathrm{E}-02$ & $7.0 \mathrm{E}+00$ \\
\hline $241 \mathrm{Pu}$ & $1.0 \mathrm{E}-01$ & 2.7 E-01 & $1.7 \mathrm{E}+08$ & $4.7 \mathrm{E}-03$ & $1.7 \mathrm{E}-02$ & $3.3 E+09$ & $8.8 E-02$ & $3.3 \mathrm{E}-01$ \\
\hline $241_{\mathrm{Am}}$ & $3.0 \mathrm{E}-01$ & $5.4 \mathrm{E}-03$ & $5.2 \mathrm{E}+08$ & $1.4 E-02$ & $2.6 \mathrm{E}+00$ & $9.6 \mathrm{E}+09$ & $2.6 \mathrm{E}-01$ & $4.8 E+01$ \\
\hline${ }^{242} \mathrm{Cm}$ & 5.4 E-09 & $2.7 \mathrm{E}-01$ & $9.3 \mathrm{E}+00$ & $2.5 E-10$ & $9.3 E-10$ & $1.7 \mathrm{E}+02$ & 4.7 E-09 & $1.7 E-08$ \\
\hline${ }^{244} \mathrm{Cm}$ & $1.6 \mathrm{E}-03$ & $1.1 E-02$ & $2.8 \mathrm{E}+06$ & $7.5 \mathrm{E}-05$ & $6.9 \mathrm{E}-03$ & $5.2 \mathrm{E}+07$ & $1.4 \mathrm{E}-03$ & $1.3 \mathrm{E}-01$ \\
\hline Totals & $1.6 E+02$ & $\ldots$ & $2.9 E+11$ & $7.7 \mathrm{E}+00$ & $5.0 \mathrm{E}+00$ & $5.3 E+12$ & $1.4 E+02$ & $9.3 \mathrm{E}+01$ \\
\hline
\end{tabular}

${ }^{\mathrm{A}_{2}}$ values taken from 49 CFR 173.435, 1995, "Shippers--General Requirements for Shipments and Packagings," Code of Federal Regulations, as amended.

Maximum expected source term derived using the solid tank waste activity concentrations (Ci/L) and multiplying by the factor 0.047 such that the total Doorstop radioactive loading results in a dose rate less than $2 \mathrm{mSv} / \mathrm{h}(200 \mathrm{mrem} / \mathrm{h})$ at the package surface.

cWorst-case source term assumes $875 \mathrm{~mL}(29.6 \mathrm{oz})$ of solid tank waste.

d240 $\mathrm{Pu}$ conservatively set equal to ${ }^{239} \mathrm{Pu}$.

Evalues taken from WHC-SD-WM-SARR-016, Rev. 2 (WKC 1996). Daughters calculated using ORIGEN2.

fThis radionuclide is a daughter as defined in $49 \mathrm{CFR} 173.433$; therefore, its activity was set to 0 for the $A_{2}$ calculations.

WHC, 1996, Iank Waste Compositions and Atmospheric Dispersion Coefficients for Use in Safety Analys is Consequence Assessments, WHC-SD-LM-SARR-016, Rev, 2, Westinghouse Hanford Company, Richl and, Washington. 
HNF-SD-TP-SARP-023 Rev. 0

\subsection{CONTENT RESTRICTIONS}

\subsubsection{Radioactive Materials}

Solid, liquid, or slurry samples are limited to a maximum of $125 \mathrm{~mL}$ (4.3 fl oz) per Doorstop container. These samples are limited to a maximum of $875 \mathrm{~mL}(29.6 \mathrm{fl}$ oz) per Doorstop Sample Carrier System when seven maximum loaded Doorstop containers are in the package. Radioactivity in the contents must be bounded by the material limits shown in Table A3-1. A maximum of $0.74 \mathrm{TBq}(20 \mathrm{Ci})$ or $15 \mathrm{~g}$ of fissile material applies to shipments in the Doorstop Sample Carrier System.

\subsubsection{Nonradioactive Materials}

Nonradioactive materials are (1) aqueous solutions or solid mixtures of oxides, nitrites, nitrates, phosphates, sulfates, fluorides, chlorides, and tricalcium aluminate or (2) organic compounds or extraction liquids. 


\section{HNF-SD-TP-SARP-023 Rev. 0}

This page intentionally left blank. 
HNF-SD-TP-SARP-023 Rev. 0

\subsection{TRANSPORT SYSTEM}

\subsection{TRANSPORTER}

The Doorstop Sample Carrier System is transported by an exclusive-use vehicle. The vehicle may transport two Doorstop Sample Carrier Systems at a time. Transfer of the Doorstop Sample Carrier System is restricted to trucks 1C392 and 1C393. Other vehicles may be authorized to transfer the Doorstop Sample Carrier System, provided it is shown that they (1) have equivalent gross vehicle weight limits, tiedown frames, and overhead hoist capacities and heights and (2) are generally similar to the previously mentioned vehicles.

\subsection{TIEDOWN SYSTEM}

The tiedown system for the Doorstop Sample Carrier System is shown in Figure A4-1. The tiedown strap assembly shall have a minimum tensile strength of $907 \mathrm{~kg}(2,000 \mathrm{lb})$. An analysis and discussion of the tiedown system are provided in Part B, Section 10.0.

\subsection{SPECIAL TRANSFER REQUIREMENTS}

The following requirements are acceptable based on the qualifications of the certified $\mathrm{N}-55$ overpack and DOT 208-L drum for protection and containment of the Doorstop container and contents.

\subsubsection{Routing and Access Control}

The Doorstop Sample Carrier System shall be transported north of the Wye Barricade following the below restrictions. Routing between the 200 Areas and the 300 Area shall require the roads to be closed to prevent public access during the transport.

\subsubsection{Radiological Limitations}

There are two sets of dose rate limitations based on the "maximum expected" and "worst case" source terms. Both source terms can result in exceeding dose rate limits associated with general transport conditions and at least one of the exclusive-use conditions. Therefore, the two sets of limits identified below were established. Exclusive-use transportation, following the modified conditions identified, applies when using these limits. The "maximum expected" limitations are based on a mixture of general transportation conditions and exclusive conditions. The "worst case" limitations are based on exclusive-use conditions. In both sets of limitations, limits such as the use of a closed vehicle and maximum vehicle surface dose were not used.

- Maximum expected: Transportation dose rate limitations are: the accessible surface of the package and the exterior surface of the vehicle must be below $2 \mathrm{mSv} / \mathrm{h}(200 \mathrm{mrem} / \mathrm{h})$, less than $0.1 \mathrm{mSv} / \mathrm{h}$ 
HNF-SD-TP-SARP-023 Rev. 0

Figure A4-1. Tiedown Configuration.

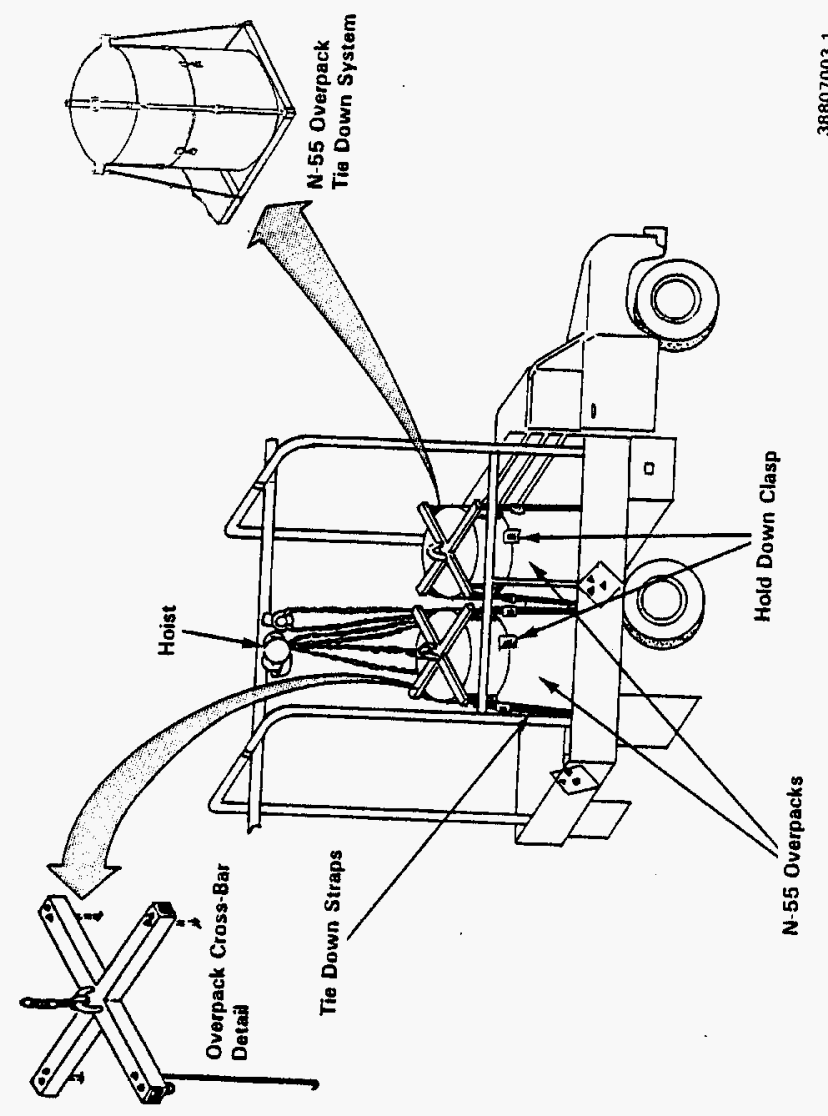




$$
\text { HNF-SD-TP-SARP-023 Rev. } 0
$$

(10 $\mathrm{mR} / \mathrm{h}$ ) at $2 \mathrm{~m}$ from the package, and less than $0.02 \mathrm{mSv} / \mathrm{h}$ $(2 \mathrm{mR} / \mathrm{h})$ in the cab of the transporter (49 CFR 173.441). If dose rates exceed these limits, refer to the next paragraph.

- Worst case: Follow the administrative controls found in Part A, Section 6.5 (Excessive Dose Rate Transport). Transportation dose rate limitations are: the accessible surface of the package must be below $10 \mathrm{mSv} / \mathrm{h}(1000 \mathrm{mrem} / \mathrm{h})$, the exterior surface of the vehicle must be below $2 \mathrm{mSv} / \mathrm{h}(200 \mathrm{mrem} / \mathrm{h})$, less than $0.1 \mathrm{mSv} / \mathrm{h}$ $(10 \mathrm{mrem} / \mathrm{h})$ at $2 \mathrm{~m}$ from the exterior surface of the vehicle, and less than $0.05 \mathrm{mSv} / \mathrm{h}(5 \mathrm{mrem} / \mathrm{h})$ in the cab of the transporter if the driver is a qualified radiological worker. If the dose rates exceed these limits, contact Packaging Engineering for direction.

External contamination limits are as shown in Table A4-1 for the exterior of the package.

Table A4-1. External Package Contamination Limits.

\begin{tabular}{|l|c|c|c|}
\hline \multirow{2}{*}{ Contaminant } & \multicolumn{3}{|c|}{ Maximum permissible limits } \\
\cline { 2 - 4 } & $\mathrm{Bq} / \mathrm{cm}^{2}$ & $\mu \mathrm{Ci} / \mathrm{cm}^{2}$ & $\mathrm{dpm} / \mathrm{cm}^{2}$ \\
\hline \hline $\begin{array}{l}\text { Beta and gamma emitters and } \\
\text { Low-toxicity alpha emitters }\end{array}$ & 0.4 & $10^{-5}$ & 22 \\
\hline $\begin{array}{l}\text { Alb other alpha-emitting } \\
\text { radionuclides }\end{array}$ & 0.04 & $10^{-6}$ & 2.2 \\
\hline
\end{tabular}

Source: 49 CFR 173.443, 1995, "Shippers--General Requirements for Shipments and Packagings," Code of Federal Regulations, as amended.

\subsubsection{Time Restrictions}

Flammable gas generation limits the time the Doorstop container can remain sealed without approaching flammable limits. Generally, the maximum time a Doorstop container can remain sealed is shown in Table A4-2. Since flammability is a significant safety item, the worst-case source term is used.

Table A4-2. Gas Generation in $1.6-\mathrm{mL}, 20-\mathrm{mL}$, and $125-\mathrm{mL}$ Samples in the Doorstop Container.

\begin{tabular}{|c|c|c|c|}
\hline \multirow[b]{2}{*}{ Payload volume } & \multicolumn{3}{|c|}{ Worst-case material } \\
\hline & $1.6 \mathrm{~mL}$ & $20 \mathrm{~mL}$ & $125 \mathrm{~mL}$ \\
\hline Shipping window & 39 days & 6.4 days & 4.8 days \\
\hline $\begin{array}{l}\text { Pressure rise to } 50 \% \text { lower flammability } \\
\text { limit (psi) }\end{array}$ & 0.455 & 0.456 & 0.456 \\
\hline Pressure rise in 45 days (psi) & 0.52 & 3.19 & 4.24 \\
\hline
\end{tabular}

Because several of the generic shipping configurations have short time limits, alternate time limits based on concentration ranges are presented. Table A4-3 shows the material concentration ranges (four) and shipping windows 
relative to the sample sizes. These four ranges are based on percentages of the worst-case material. Table A4-4 shows the maximum concentration for each radionuclide for the four ranges. The header in Table A4-4 shows each range by case numbers 1 though 4 and the maximum percentage of the range.

Table A4-3 shows these nuclide content case numbers cross-referenced relative to sample size and concentration ranges.

Table A4-3. Gas Generation Shipping Windows Limits Based on Concentration.

\begin{tabular}{|c|c|c|c|}
\hline Sample & $\begin{array}{c}\text { Material } \\
\text { concentration } \\
\text { range }\end{array}$ & $\begin{array}{l}\text { Shipping } \\
\text { window } \\
\text { (days) }\end{array}$ & $\begin{array}{l}\text { Nucl ide } \\
\text { content } \\
\text { case No. }\end{array}$ \\
\hline \multirow[t]{4}{*}{$1.6 \mathrm{~mL}$ or Less in Doorstop carrier } & $>75 \%$ and $<100 \%$ & 39 & 1 \\
\hline & $>50 \%$ and $\leq 75 \%$ & 50 & 2 \\
\hline & $>25 \%$ and $\leq 50 \%$ & 70 & 3 \\
\hline & $>0 \%$ and $\leq 25 \%$ & 117 & 4 \\
\hline \multirow[t]{4}{*}{$20 \mathrm{~mL}$ or less in Lead pak cylinder } & $>75 \%$ and $<100 \%$ & 6.4 & 1 \\
\hline & $>50 \%$ and $\leq 75 \%$ & 8 & 2 \\
\hline & $>25 \%$ and $\leq 50 \%$ & 11.5 & 3 \\
\hline & $>0 \%$ and $\leq 25 \%$ & 19 & 4 \\
\hline \multirow[t]{4}{*}{$125 \mathrm{~mL}(4.3 \mathrm{floz})$} & $>75 \%$ and $<100 \%$ & 4.8 & 1 \\
\hline & $>50 \%$ and $\leq 75 \%$ & 6 & 2 \\
\hline & $>25 \%$ and $\leq 50 \%$ & 8.5 & 3 \\
\hline & $>0 \%$ and $\leq 25 \%$ & 14.5 & 4 \\
\hline
\end{tabular}

When using the shipping window limits from Table A4-3, the shipper must ensure that the upper concentration level of the range shown in Table A4-4 is not exceeded for any nuclide. It is acceptable for the concentration to be lower than the bottom of the range. It is also acceptable for a nuclide to not be present in the payload. 
Table A4-4. Nuclide Content $(\mathrm{Ci} / \mathrm{L})$ by Case Number.

\begin{tabular}{|c|c|c|c|c|}
\hline Nuclide & $\begin{array}{l}\text { Case } 1 \\
\text { Payload activity } \\
\text { Concentration } 100 \% \text { of } \\
\text { worst case material }{ }^{a}\end{array}$ & $\begin{array}{l}\text { Case } 2 \\
\text { Payl oad activity } \\
\text { concentration } 75 \% \text { of } \\
\text { worst case material }\end{array}$ & $\begin{array}{c}\text { Case } 3 \\
\text { Payload activity } \\
\text { concentration } 50 \% \text { of } \\
\text { worst case material } \\
\end{array}$ & $\begin{array}{l}\text { Case } 4 \\
\text { Payload activity } \\
\text { concentration } 25 \% \text { of } \\
\text { worst case material }\end{array}$ \\
\hline${ }^{14} \mathrm{C}$ & $4.3 \mathrm{E}-06$ & $3.2 \mathrm{E}-06$ & 2.2 E-06 & $1.1 \mathrm{E}-06$ \\
\hline${ }^{60} \mathrm{Co}$ & $1.3 \mathrm{E}-02$ & $9.8 \mathrm{E}-03$ & $6.5 \mathrm{E}-03$ & $3.3 \mathrm{E}-03$ \\
\hline${ }^{79} \mathrm{Se}$ & 4.6 E- 07 & $3.5 \mathrm{E}-07$ & $2.3 \mathrm{E}-07$ & $1.2 \mathrm{E}-07$ \\
\hline${ }^{90} \mathrm{sr}$ & $7.8 \mathrm{E}+01$ & $5.9 E+01$ & $3.9 \mathrm{E}+01$ & $2.0 \mathrm{E}+01$ \\
\hline $90 Y^{b}$ & $7.8 E+01$ & $5.9 \mathrm{E}+01$ & $3.9 E+01$ & $2.0 E+01$ \\
\hline${ }^{99} \mathrm{TC}$ & 3.2 E-01 & 2.4 E-01 & $1.6 \varepsilon-01$ & $8.0 \mathrm{E}-02$ \\
\hline${ }^{106} \mathrm{Ru}$ & $1.9 \mathrm{E}-06$ & $1.4 E-06$ & $9.5 \mathrm{E}-0.07$ & $4.8 \mathrm{E}-07$ \\
\hline${ }^{106} \mathrm{Rh}^{\mathrm{b}}$ & $1.9 \mathrm{E}-06$ & $1.4 \mathrm{E}-06$ & $9.5 E-07$ & $4.8 \mathrm{E}-07$ \\
\hline${ }^{125} \mathrm{sb}$ & $4.9 \mathrm{E}-03$ & $3.7 \mathrm{E}-03$ & $2.5 \mathrm{E}-03$ & $1.2 \mathrm{E}-03$ \\
\hline${ }^{129} \mathrm{I}$ & $1.7 \mathrm{E}-04$ & $1.3 \mathrm{E}-04$ & $8.5 \mathrm{E}-0.05$ & $4.3 \mathrm{E}-05$ \\
\hline${ }^{134} \mathrm{Cs}$ & $2.5 \mathrm{E}-04$ & $1.9 \mathrm{E}-04$ & $1.3 E-04$ & $6.3 E-05$ \\
\hline${ }^{137} \mathrm{Cs}$ & $2.7 \mathrm{E}+00$ & $2.0 \mathrm{E}+00$ & $1.4 E+00$ & $6.8 \mathrm{E}-01$ \\
\hline $137 \mathrm{~m}_{\mathrm{Ba}}{ }^{\mathrm{b}}$ & $2.6 \mathrm{E}+00$ & $2.0 \mathrm{E}+00$ & $1.3 \mathrm{E}+00$ & $6.5 E-01$ \\
\hline${ }^{144} \mathrm{Ce}$ & $9.2 \mathrm{E}-09$ & $6.9 E-09$ & $4.6 \mathrm{E}-09$ & 2.3 E-09 \\
\hline${ }^{144} \mathrm{pr}^{\mathrm{b}}$ & 9.2 E-09 & $6.9 \mathrm{E}-09$ & 4.6 E-09 & $2.3 \mathrm{E}-09$ \\
\hline${ }^{154} \mathrm{Eu}$ & $3.0 \mathrm{E}-01$ & $2.3 \mathrm{E}-01$ & $1.5 E-01$ & $7.5 \mathrm{E}-02$ \\
\hline${ }^{155} \mathrm{Eu}$ & $1.4 \mathrm{E}-04$ & $1.1 E-04$ & 7.0 E- 05 & 3.5 E- 05 \\
\hline $237_{\mathrm{Np}}$ & $2.7 \mathrm{E}-02$ & 2.0 E-02 & $1.4 \mathrm{E}-02$ & $6.8 \mathrm{E}-03$ \\
\hline${ }^{238} \mathrm{Pu}$ & $5.1 \mathrm{E}-03$ & $3.8 \mathrm{E}-03$ & $2.6 \mathrm{E}-03$ & $1.3 \mathrm{E}-03$ \\
\hline${ }^{239} \mathrm{Pu}$ & $4.3 \mathrm{E}-02$ & 3.2 E-02 & 2.2 E-02 & $1.1 E-02$ \\
\hline${ }^{240} \mathrm{Pu}_{\mathrm{C}} \mathrm{C}$ & $4.3 \mathrm{E}-02$ & $3.2 \mathrm{E}-02$ & 2.2 E-02 & $1.1 E-02$ \\
\hline${ }^{241} \mathrm{Pu}$ & $1.0 \mathrm{E}-01$ & $7.5 \mathrm{E}-02$ & 5.0 E-02 & $2.5 E-02$ \\
\hline${ }^{241} \mathrm{Am}$ & $3.0 \mathrm{E}-01$ & $2.3 E-01$ & $1.5 \mathrm{E}-01$ & $7.5 \mathrm{E}-02$ \\
\hline${ }^{242} \mathrm{~cm}$ & 5.4 E-09 & 4.1 E-09 & $2.7 \mathrm{E}-09$ & $1.4 \mathrm{E}-09$ \\
\hline${ }^{244} \mathrm{~cm}$ & $1.6 \mathrm{E}-03$ & $1.2 \mathrm{E}-03$ & 8.0 E-04 & 4.0 E-04 \\
\hline Totals & $1.6 E+02$ & $1.2 E+02$ & $8.0 E+01$ & $4.0 E+01$ \\
\hline
\end{tabular}

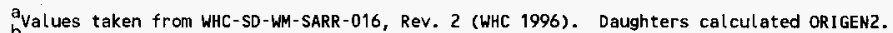

b This radionuclide is a daughter as defined in 49 CFR 173.433; therefore, its activity was set to 0 for 2 the A2 calculations.

49 CFR 173, 1995, "Shippers--General Requirements for Shipments and Packagings," Code of Federal Regulations, as amended.

WHC, 1996, Tank Waste Compositions and Atmospheric Dispersion Coefficients for Use in Safety Analys is Consequence Assessments, WHC-SD-HM-SARR-016, Rev. 2, Westinghouse Hanford Company, Richland, Wastington. 


$$
\text { HNF-SD-TP-SARP-023 ReV. } 0
$$

\subsubsection{Speed Limitations}

The transport vehicle shall follow the posted speed limits.

\subsubsection{Environmental Conditions}

Transport shall not take place under icy conditions (unless the roads have been plowed and sanded) or when visibility is seriously impaired by fog, rain, snow, or dust (less than one mile visibility).

\subsubsection{Frequency of Use and Milage Limitations}

There are no frequency of use or mileage restrictions on the Doorstop Sample Carrier System.

\subsubsection{Escort and Emergency Response}

Compliance with the requirements of WHC-CM-4-1, Emergency Plan, is the responsibility of the shipper.

\subsubsection{Exclusive Use}

The transport vehicle shall not carry any other packagings containing hazardous material during the Doorstop Sample Carrier System(s) transfer. 
HNF-SD-TP-SARP-023 Rev. 0

\subsection{ACCEPTANCE OF PACKAGING FOR USAGE}

\subsection{NEW PACKage acceptance testing}

Acceptance testing and inspections are required to evaluate the performance of the Doorstop Sample Carrier System per the requirements of this SARP.

The following are the inspection and testing requirements for the new packaging. Specific procedures shall be written by the user and approved by Packaging Engineering, prior to use, to ensure the packaging is not damaged during inspection and testing operations.

A1l newly fabricated Doorstop Sample Carrier System components shall be inspected and tested per the following requirements prior to first use in the field.

\subsubsection{Acceptance Requirements}

Fabrication acceptance requirements for the Doorstop Sample Carrier System are based upon the THI and Quality Level (QL) of the component to be inspected or tested. QL A-3 and B-3 components or activities as defined in Part A, Section 7.0, are important to safety and require proper documentation if they are not inspected or tested as required by this section.

\subsubsection{Inspection and Testing}

The following inspections and testing shall be performed on newly fabricated Doorstop Sample Carrier System components. QL A-3 components are considered important to safety, and the inspections and testing shall be documented and maintained per Part A, Section 5.1.3. QL A-3 testing and inspection requirements are shown in Table A5-1.

Table A5-1. Quality Level A-3 Fabrication Testing and Inspections.

\begin{tabular}{|l|l|}
\hline \multicolumn{1}{|c|}{ Component test/inspection } & \multicolumn{1}{c|}{ Acceptance requirements } \\
\hline \hline Doorstop container & $\begin{array}{l}\text { Meets all the dimensions, materials and fabrication } \\
\text { requirements of the drawings (Part A, Section 10.1) }\end{array}$ \\
\hline $\begin{array}{l}\text { Doorstop Sample Carrier system } \\
\text { assembly test }\end{array}$ & $\begin{array}{l}\text { Each component is placed ins ide the respective component and } \\
\text { closes and functions properly (i.e. Doorstop ins ide Doorstop } \\
\text { Container, inside DOT 208-L drum, inside N-55 overpack) }\end{array}$ \\
\hline Shielding 100\% lead gamma scan & $\begin{array}{l}\text { No deficiencies that would reduce the effective shielding } \\
\text { thickness by } 10 \% \text { or more }\end{array}$ \\
\hline Doorstop container leak test & Meets ANSI N14.5 leaktight leak rate of $5.81 \times 10^{-5} \mathrm{std-cc/s}$ \\
\hline
\end{tabular}

ANSI = American National Standards Institute.

WHC = West inghouse Hanford Company.

ANS1, 1987, American National Standard for Radioactive Materials - Leakage Tests on packages for Shipment, ANS! N14.5 American National Standards Institute, Inc., New York, New York. 
QL B-3 component fabrication inspections and tests are required to be performed as shown in Table A5-2. QL B-3 components are considered important to safety, and the inspections and testing shall be documented and maintained per Part A, Section 5.1.3.

Table A5-2. Quality Level B-3 Fabrication Inspections and Tests.

\begin{tabular}{|l|l|}
\hline \multicolumn{1}{|c|}{ Component inspection/test } & \multicolumn{1}{c|}{ Acceptance requirements } \\
\hline \hline Lifting fixture load test & Hanford Site Hoisting and Rigging Manual (RL 1993) \\
\hline DOT 208-L drum visual inspection & Per N-55 Overpack SARP drawing and requirements \\
\hline N-55 overpack visual inspection & Per N-55 Overpack SARP drawings and requirenents \\
\hline Lifting fixture visual inspection & Meets drawing material and fabrication requirements \\
\hline
\end{tabular}

SARP = Safety Analysis Report for Packaging.

RL, 1993, Hanford Site Hoisting and Rigging Manual, DOE/RL-92-36, Rev. 0 , U.S. Department of Energy, Richland Operations office, Richland, Washington.

QL $C-3$ component fabrication inspections and tests are required to be performed as shown in Table A5-3, QL C-3 activities are not considered important to safety.

Table A5-3. Quality Level C-3 Fabrication Tests and Inspections.

\begin{tabular}{|l|l|}
\hline \multicolumn{1}{|c|}{ Component inspection/test } & \multicolumn{1}{c|}{ Acceptance Requirements } \\
\hline \hline Doorstop sample carrier visual inspection & Drawing material and fabrication requirements \\
\hline Tiedown straps & Meet purchase requis ition requi rements \\
\hline Overpack gasket & Meets $\mathrm{N}-55$ overpack drawing requirements \\
\hline
\end{tabular}

\subsubsection{Documentation}

Acceptance testing and inspection verification and results sha11 be documented with QC periodic verification of the documentation and maintained for the life of the package or five years, whichever is longer.

\subsection{PACKAGING FOR REUSE}

The following applies to the Doorstop Sample Carrier System components that have previously been used to transport radioactive materials.

\subsubsection{Acceptance Requirements}

Acceptance requirements for the reuse of the Doorstop Sample Carrier System are based upon the QL of the component to be inspected or tested. QL $A-3$ activities are considered important to safety, and the inspections and testing shall be documented and maintained per Part A, Section 5.1.3. QL A-3 
HNF-SD-TP-SARP-023 Rev. 0

components or activities, as defined in Part A, Section 7.0, are important to safety and require proper documentation if they are not inspected or tested as required by this section.

\subsubsection{Inspection and Testing}

Each of the following inspections shall be performed prior to reuse of any or all of the Doorstop Sample Carrier System components. The inspections are based on the QL of the component. QL A-3 component inspections are shown in Table A5-4.

Table A5-4. Quality Level A-3 Component Inspections.

\begin{tabular}{|l|l|}
\hline \multicolumn{1}{|c|}{ Component/inspection } & \multicolumn{1}{c|}{ Acceptance criteria } \\
\hline Doorstop container cleaned and decontaminated & Table AL-1 limits \\
\hline Doorstop container visual inspection & $\begin{array}{l}\text { No weld degradation. No dents or damage to the } \\
\text { container that coutd affect the containment of the } \\
\text { packaging }\end{array}$ \\
\hline Doorstop container o-ring visual inspection & $\begin{array}{l}\text { Replace if signs of aging, cracking, hardening or } \\
\text { stretching are present }\end{array}$ \\
\hline Doorstop container sealing surface & No visible scratches \\
\hline
\end{tabular}

QL B-3 component inspections are 1isted in Table A5-5. QL B-3 activities are considered important to safety, and the inspections and testing shall be documented and maintained per Part A, Section 5.1.3.

Table A5-5. Quality Leve1 B-3 Component Inspections.

\begin{tabular}{|l|l|}
\hline \multicolumn{1}{|c|}{ Component inspection } & \multicolumn{1}{|c|}{ Acceptance requirements } \\
\hline \hline N-55 overpack decontamination and visual inspection & $\begin{array}{l}\text { Table A4-1 decontamination I imits and no signs of } \\
\text { weld degradat ion, Ioss of rivets, large dents } \\
\text { (greater than } 1 / 4 \text { of each overpack half), or } \\
\text { visible foam }\end{array}$ \\
\hline $\begin{array}{l}\text { DOT 208-L drun decontamination and visual } \\
\text { inspection }\end{array}$ & $\begin{array}{l}\text { Table A4-1 decontamination limits and no signs of } \\
\text { weld degradation or dents in the drum that prevent } \\
\text { proper closure of the lid }\end{array}$ \\
\hline Lifting fixtures visual inspection & \begin{tabular}{l} 
No signs of weld degradation \\
\hline
\end{tabular} \\
\hline
\end{tabular}

DOT = U.S. Department of Transportation.

QL C-3 component inspections are 1isted in Table A5-6. QL C-3 activities are not considered important to safety. 
HNF-SD-TP-SARP-023 Rev. 0

Table A5-6. Quality Leve1 C-3 Component Inspections.

\begin{tabular}{|l|l|}
\hline \multicolumn{1}{|c|}{ Component inspection } & \multicolumn{1}{c|}{ Acceptance requirements } \\
\hline \hline N-55 overpack gasket visual inspection & $\begin{array}{l}\text { Replace if signs of aging, cracking, hardening, or } \\
\text { stretching are present }\end{array}$ \\
\hline Tiedown straps visual inspection & $\begin{array}{l}\text { Replace if signs of fraying or breaking are } \\
\text { present }\end{array}$ \\
\hline Doorstop sample carrier visual inspection & $\begin{array}{l}\text { No weld degradation. No dents or damage to the } \\
\text { container that could affect the containment of the } \\
\text { packaging }\end{array}$ \\
\hline
\end{tabular}

\subsubsection{Documentation}

All inspections shall be documented in procedures and/or inspection checklists, and the documentation shall be periodically reviewed by $Q C$. The documentation shall be maintained for the life of the package or five years, whichever is longer. 
HNF-SD-TP-SARP-023 Rev. 0

\subsection{OPERATING REQUIREMENTS}

\subsection{GENERAL REQUIREMENTS}

The following are requirements for the use of the Doorstop Sample Carrier system. Prior to use, specific operating procedures shall be written by the user and approved in accordance with WHC-CM-2-14. Items or activities labeled as QL A-3 and B-3 shall be considered "important to safety" for purposes of this SARP and shall be followed as written in this SARP. Modification of QL $A-3$ and $B-3$ steps will require an engineering change notice and unresolved safety question screening.

\subsection{LOADING PACKAGE}

The Doorstop Sample Carrier System operational requirements are implemented in detailed plant operating procedures.

\subsubsection{Lead Pak Cylinder}

Samples are loaded in vials and placed into the lead pak cylinders, packaged in slip lid or food pack cans, and loaded into the Doorstop container as follows:

1. Load the sample in a vial with a screw-on lid and place it inside a plastic bag. (QL C-3)

2. Place the bagged sample inside the lead pak cylinder. (QL C-3)

3. Prepare the slip lid or food pack can by placing a cylinder made from three layers of $0.159-\mathrm{cm}-(0.625-$ in.- $)$ thick lead wrap-around inside the can. Place three disk-shaped layers of $0.159-\mathrm{cm}-$ (0.625-in.-) thick lead wrap on the bottom of the can. Prepare three disk-shaped layers of $0.159-\mathrm{cm}-(0.625-\mathrm{in} .-)$ thick lead wrap for placement within the top portion of the can. (QL B-3)

4. Place the lead pak cylinder inside the lead wrap in the can. Place three lead disks inside the can over the leak pak cylinder. (QL B-3)

5. The slip lid can shall be taped shut and placed inside the Doorstop container. The food pack can shall be sealed and placed inside the Doorstop container. (QL C-3)

6. The Doorstop container 1id, with gasket in place, shall be firmly hand tightened. (QL A-3)

\subsubsection{Bottled Samples in Can}

Samples loaded in bottles and packed in slip 1id, food pack or paint cans loaded into in the Doorstop container shall be loaded as follows: 


$$
\text { HNF-SD-TP-SARP-023 Rev, } 0
$$

1. The sample shall be loaded in a polyethylene or glass bottle (maximum $125 \mathrm{~mL}$ ). The bottle shall be sealed with a polyethylene or Teflon 4 lined cap. The bottle shall be double bagged in plastic bags that are heat sealed and/or taped shut. (QL C-3)

2. The bagged sample bottle shall be placed inside a slip 1id, food pack can, or paint can filled with non-cellulosic inert absorbent. The absorbent material shall be capable of absorbing twice the contents of the bottle. (QL B-3)

3. Close the can by taping shut the slip lid, sealing the food pack lid, or tamping closed the paint can lid. Place the can inside the Doorstop container. (QL A-3)

4. The Doorstop container lid, with the gasket in place, shall be firmly hand-tightened. (QL A-3)

\subsubsection{Doorstop Sample Carrier}

Samples loaded in stainless steel or lead-lined Doorstop sample carriers packaged in the Doorstop container shall be loaded as follows:

1. Samples contained in pipette tips shall be placed into the plastic insert-lined Doorstop sample carrier cavity. (QL C-3)

2. The lead plug, containing the gasket, shall be lowered into the Doorstop sample carrier cavity. (QL B-3)

3. The Doorstop sample carrier yoke shall be positioned over the plug and firmly hand tightened. (QL C-3)

4. Doorstop sample carriers shall be placed in the Doorstop container with absorbent material placed on top of the Doorstop to absorb any liquid in the event of a spill. (QL B-3)

5. The Doorstop container 1id, with gasket in place, shall be firmly hand tightened. (QL A-3)

\subsubsection{Doorstop Container}

The three above Doorstop container configurations shall be loaded into the drum and overpack as follows:

1. Position the bottom and middle sections of beadboard filler inside the DOT 208-L drum. (QL B-3)

2. Position up to seven stainless steel Doorstop containers inside the seven compartments within the beadboard. (QL B-3)

\footnotetext{
${ }^{4}$ Teflon is a tradenark of E. I, du Pont de Nemours and Company.
} 
HNF-SD-TP-SARP-023 ReV. 0

3. Place the third section of beadboard on top of the Doorstop containers. (QL B-3)

4. Place drum lid containing a gasket, lock ring, and bolt on the drum. (QL B-3)

5. Torque the lock ring bolt to $54 \pm 5 \mathrm{Nm}$ (40 $\pm 5 \mathrm{ft}-1 \mathrm{~b}$ ) while hammer tapping the lock ring using a rubber or leather mallet to assure an adequate seal. (QL B-3)

\subsubsection{N-55 Overpack}

1. With the drum inside the bottom half of the $\mathrm{N}-55$ overpack, position the top half of the $\mathrm{N}-55$ overpack on the bottom half. (QL B-3)

2. Secure the top half of the N-55 overpack to the bottom half by fastening the four toggle clamps (barrel pins). This shall be done by adjusting the " $T$ " bar on the clamps such that the clamps may be closed with minimum force. Reopen the clamps, and rotate the "T" bar on all four clamps two ful1 $360^{\circ}$ turns clockwise. Then close the clamps (Part B, Section 7.6.2). (QL B-3)

3. Verify that radiation dose rates do not exceed the following limits: $2 \mathrm{mSv} / \mathrm{h}(200 \mathrm{mrem} / \mathrm{h})$ on the exterior surface of the $\mathrm{N}-55$ overpack, $2 \mathrm{mSv} / \mathrm{h}(200 \mathrm{mrem} / \mathrm{h})$ at the vehicle edge, $0.1 \mathrm{mSv} / \mathrm{h}$ $(10 \mathrm{mrem} / \mathrm{h})$ at $2 \mathrm{~m}(7 \mathrm{ft})$ from the vehicle edge, and $0.02 \mathrm{mSv} / \mathrm{h}$ ( $2 \mathrm{mrem} / \mathrm{h}$ ) at any normally occupied space (driver location), unless the worker is a qualified Hanford Site radiological worker in which case the limits is $0.05 \mathrm{mSv} / \mathrm{h}(5 \mathrm{mrem} / \mathrm{h})$. If dose rates exceed the limits, follow procedures given in Part A, Section 6.5.

4. Removable contamination on external surfaces of the Doorstop Sample Carrier System sha11 not exceed Table A4-1 values. (QL A-3)

5. Attach a tamper-indicating seal to the $\mathrm{N}-55$ overpack to provide evidence that the package has not been opened by unauthorized persons. (QL C-3)

6. If it is not already in place, attach the lifting and tiedown yoke to the top of the $\mathrm{N}-\mathbf{5 5}$ overpack. Place the tiedown straps on tiedown yoke and frame. Carefully tension the straps between the yoke and the transporter frame to ensure even tension on all four straps. (QL B-3)

7. Labe] the N-55 overpack per 49 CFR 172 and mark per 49 CFR 173. (QL C-3)

NOTE: Ensure time limits in Part A, Section 4.3 .3 are not exceeded. 
HNF-SD-TP-SARP-023 Rev, 0

\subsubsection{Lifting}

A11 Doorstop Sample Carrier System 1 ifting operations, procedures, and equipment sha11 conform to the requirements of DOE-RL-92-36, Hanford Site Hoisting and Rigging Manual (RL 1993).

\subsubsection{Installation of Package onto Transport Vehicle}

1. Transfer the Doorstop Sample Carrier System to the transport vehicle using appropriate lifting technique from Part $B$, Section 7.6.1.2.1. (QL B-3)

2. Tiedown package to truck. (QL C-3)

3. Ensure Doorstop Sample Carrier System is conspicuously and durably marked as required by DOT regulations. (QL C-3)

\subsection{RECEIPT OF PACKAGE}

The Doorstop Sample Carrier System shall be received by the receiving facility and transferred into the facility using proper Plant operating Procedures.

\subsubsection{Off-Loading}

1. Survey the $\mathrm{N}-55$ overpack prior to opening to ensure removable contamination on external surfaces of the $\mathrm{N}-55$ overpack does not exceed Table A4-1 1imits. (QL A-3)

2. Verify the integrity of the tamper-indicating seal on the $\mathrm{N}-55$ overpack. (QL B-3)

3. Remove the tiedowns and unlock the toggle clamps on the $\mathrm{N}-55$ overpack. (QL C-3)

4. Remove top half of the $\mathrm{N}-55$ overpack. (QL $\mathrm{C}-3$ )

5. Remove the DOT 208-L drum 1 id and the top inner spacer. (QL C-3)

6. Survey the DOT 208-L drum lid and top inner spacer prior to removing the Doorstop Container(s) to ensure a contamination spread will not occur while removing the shipping container. (QL $A-3)$

7. Remove the Doorstop Container(s) from the drum. (QL A-3)

8. Doorstop sample carriers, slip lid, food pack, or paint cans shall not be removed from the Doorstop containers outside of the buildings. (QL A-3) 


$$
\text { HNF-SD-TP-SARP-023 Rev. } 0
$$

\section{CAUTION: THE DOORSTOP CONTAINER MAY BE PRESSURIZED DUE TO THE}

BUILDUP OF HYDROGEN AND OTHER GASES.

\subsection{EMPTY PACKAGE (PACKAGING)}

Empty packages shall be prepared for transport per 49 CFR 173.427 or 49 CFR 173.428 (1995 version) under the conditions that the smearable internal contamination levels and the smearable external contaminations levels are acceptable per 49 CFR 173.443 (see Table A4-1). Otherwise, the package shall be reassembled and transported per Part A, Sections 6.2 and 6.3 .

\subsection{EXCESSIVE DOSE RATE TRANSPORT}

When the dose rates are in excess of $2 \mathrm{mSv} / \mathrm{h}(200 \mathrm{mrem} / \mathrm{h})$ on the surface of the package or any other limits given in Part A, Section 4.3.2, perform the following for transport.

1. Shield driver such that dose rates in the cab do not exceed $0.05 \mathrm{mSv} / \mathrm{h}(5 \mathrm{mrem} / \mathrm{h})$ if the driver is a qualified radiological worker; otherwise $0.02 \mathrm{mSv} / \mathrm{h}(2 \mathrm{mrem} / \mathrm{h})$. (QL A-3)

2. Shield package if dose rates at the edge of the transport vehicle exceed $2 \mathrm{mSv} / \mathrm{h}(200 \mathrm{mrem} / \mathrm{h})$ or one greater than $0.1 \mathrm{mSv} / \mathrm{h}$ $(10 \mathrm{mrem} / \mathrm{h})$ at $2 \mathrm{~m}(7 \mathrm{ft})$ from vehicle edge. (QL A-3)

3. Ensure that the dose rate at the accessible package surface is less than $10 \mathrm{mSv} / \mathrm{h}(1000 \mathrm{mrem} / \mathrm{h})$. Dose rate may be reduced physically. (QL A-3) 
HNF-SD-TP-SARP-023 Rev. 0

This page intentionally left blank.

A6-6 
HNF-SD-TP-SARP-023 Rev. 0

\subsection{QUALITY ASSURANCE REQUIREMENTS}

\subsection{INTRODUCTION}

This section describes the $Q A$ requirements for the procurement, fabrication, operation, and maintenance of the Doorstop Sample Carrier System. The design and fabrication of the $\mathrm{N}-55$ overpack was performed by NuPac following their 10 CFR 71, Subpart $\mathrm{H}$ Certification and those guidelines similar to those detailed below. The Doorstop Sample Carrier System components fabricated by Westinghouse Hanford Company (WHC) were programmatically controlled by WHC-CM-4-2, Quality Assurance Manual. The format and requirements for procurement, fabrication, operation, and maintenance were taken from WHC-CM-4-2; WHC-IP-0705 (WHC 1995); WHC-CM-2-14; and 10 CFR 71, Subpart $H$.

\subsection{GENERAL REQUIREMENTS}

These requirements apply to activities, such as packaging, fabrication, repair, operation and maintenance which could affect the quality of the Doorstop Sample Carrier System and associated hardware. The overall Doorstop Sample Carrier System is classified per the WHC-CM-2-14 as a THI 3.

THI 3 packaging systems defined in WHC-CM-2-14 represents the third highest level of hazard for the contents. A packaging system assigned this level must be capable of mitigating a release less than $5 \mathrm{mSv}(0.5 \mathrm{rem})$ and greater than $0.1 \mathrm{mSv}(0.01 \mathrm{rem})$ beyond the Hanford site boundaries from either a normal or accident condition of transport.

Each THI contains a QL designator consisting of two parts, an alpha designator with a numerical designator. The alpha designator assigns the fabrication, testing, use, maintenance standards and quality requirements for each item, component, or activity of the packaging system. The numeric designator following the letter is the THI number of the packaging system. The following are definitions and requirements for each Doorstop Sample Carrier System item, component, or activity.

Quality Level A-3: Critical impact on safety and associated functional requirements: items or components whose failure or malfunction could directly result in an unacceptable condition of containment or confinement, shielding, or nuclear criticality.

This $Q \mathrm{~L}$ refers to the Doorstop container containment boundary and shielding. The requirements for fabrication, operations, and maintenance shall comply with the requirements of the following: American Institute of Steel Construction (AISC), American Welding Society (AWS), international or national standards, or operational and maintenance requirements with minimum fabrication leak test requirements of $5.81 \times 10^{-5} \mathrm{std}-\mathrm{cc} / \mathrm{s}$, air.

Material required to be on hand for fabrication are ASTM or military specification materials with certificates of conformance from the Sellers. 
Any procurement of items shall be from a supplier with an approved $Q A$ program in accordance with, or equivalent to, appropriate basic requirements and supplements of ASME NQA-1. QA procurement clauses shall be imposed as applicable to ensure product quality. Specific requirements to be developed by the packaging Quality Assurance engineer and Packaging Engineering cognizant engineer.

Quality Level B-3: Major impact on safety and associated functional requirements: items or components whose failure or malfunction could indirectly result in an unacceptable condition of containment or confinement, shielding, or nuclear criticality. An unsafe condition could result only if the failure of this item or subsystem occurred in conjunction with the failure of other items or subsystem in A-3 or this level.

This QL refers to the $\mathrm{N}-55$ overpack, DOT 208-L drum closure and 1 ifting fixtures. The requirements for fabrication, operation and maintenance shall comply with the requirements of the following: AISC, AWS, international or national standards, or operational and maintenance requirements with fabrication leakage rate requirements of $10^{-1} \mathrm{~atm}-\mathrm{cc} / \mathrm{s}$, air.

Materials for fabrication require only the Seller's certificate of compliance.

Supplier QA programs shall be in accordance with, or equivalent to, appropriate basic and supplementary requirements of ASME NQA-1. QA procurement clauses shall be selectively imposed, as applicable, to ensure product quality. Specific requirements shall be developed by the responsible Packaging Engineering engineer with the assistance of the packaging Quality Assurance engineer.

Quality Level C-3: Minor impact on safety and associated functional requirements: items or components whose failure or malfunction would not reduce packaging effectiveness and would not result in an unacceptable condition of containment or confinement, shielding, or nuclear criticality, regardless of other failure in A-3, B-3 or this level.

This QL refers to the N-55 overpack gasket, tiedown system, Doorstop sample carrier, and all content containers. The requirements for fabrication, operation and maintenance shail comply with the following: AISC, AWS, international or national standards, or Flour Daniel Hanford, Inc. or Seller's prepared requirements media.

Supplier QA programs shall be in accordance with, or equivalent to, appropriate basic and supplementary requirements of ASME NQA-1. QA procurement clauses shall be selectively imposed, as applicable, to ensure product quality. Specific requirements shall be developed by the responsible Packaging Engineering engineer with the assistance of the packaging Quality Assurance engineer.

Each cognizant engineer involved with procurement, fabrication, use, or maintenance of the Doorstop Sample Carrier System components is responsible for assuring that the assigned tasks are performed in 


$$
\text { HNF-SD-TP-SARP-023 Rev. } 0
$$

accordance with controlling plans and procedures, which must in turn conform to the requirements of these QA requirements. Quality requirements for tasks are determined and documented in the plans and procedures used by the involved organizations.

Documentation and review requirements are based upon the QL of each component or activity. Changes or discoveries of non-compliance for all QL $A-3$ and $B-3$ components and activities shall be reviewed by the USQ screening process to ensure the quality and safety of the change or discovery. Changes to the SARP safety bases (contents, shielding, structural, containment, criticality) will require USQ screening regardless of QL.

\subsection{ORGANIZATION}

The organizational structure and the assignment of responsibility shall be such that quality is achieved and maintained by those who have been assigned responsibility for performing work. Quality achievement is to be verified by persons or organizations directly responsible for performing the work.

Packaging Engineering and the user operations engineering are responsible for the quality of the work performed by their respective organizations and for performing the following activities:

- Follow current requirements of this SARP, WHC-CM-4-2, and WHC-CM-2-14.

- Provide instructions for implementing QA requirements.

The responsible Quality Assurance organization is responsible for establishing and administering the applicable QA program, as stated in WHC-CM-4-2.

\subsection{QUALITY ASSURANCE ACTIVITIES}

\subsubsection{Design Control}

Al1 engineering change notices to the packaging shall be approved by Packaging Engineering.

\subsubsection{Procurement and Fabrication Control}

Procurement and fabrication of Doorstop Sample Carrier System components shall be documented and controlled based on the quality level of the component. Requirements of WHC-CM-4-2 shall be followed as required by the assigned QL. 


$$
\text { HNF-SD-TP-SARP-023 Rev. } 0
$$

Table A7-1. Procurement and Fabrication Quality Levels.

\begin{tabular}{|l|c|}
\hline \multicolumn{1}{|c|}{ Component } & Qual ity level \\
\hline \hline N-55 overpack & B-3 \\
\hline Dot 208-L drum & B-3 \\
\hline Doorstop container & A-3 \\
\hline Lifting attachments & B-3 \\
\hline Overpack gasket & $\mathrm{C}-3$ \\
\hline DoT 208-L drum gasket & $\mathrm{B}-3$ \\
\hline Doorstop sample carrier & $\mathrm{C}-3$ \\
\hline Content containers & $\mathrm{C}-3$ \\
\hline Tiedown attachments & $\mathrm{C}-3$ \\
\hline
\end{tabular}

\subsubsection{Control of Operation/Processes}

Processes affecting the quality of packaging items or services shall be controlled by instructions, procedures, drawings, checklists, or other appropriate means. These means shall ensure that process parameters are controlled with defined limits, and that specified environmental conditions are maintained. Methods for defining how process controls will be applied are defined in WHC-CM-4-2.

\subsubsection{Control of Inspection and Testing}

Fabrication and acceptance inspections shall be performed to the following guidelines.

7.4.4.1 Inspection Personnel. Inspection for acceptance shall be performed by cognizant facility QC personnel. Items fabricated by offsite suppliers will be inspected by Procurement Quality Assurance/QC personnel.

7.4.4.2 In-Process Inspection. Fabrication and acceptance inspections detailed in Part $A$, Section 5.1 are performed by cognizant facility $Q C$ personne1.

\subsubsection{Control of Operations and Maintenance}

Loading/unloading procedures shall be written by the user with appropriate reference to this SARP and will be used to ensure adequate loading, operation, and maintenance of packaging. The loading/unloading procedure identifies actions required by loading personnel to safely and properly load the Doorstop Sample Carrier System per this SARP. The loading/unloading procedures shall also identify which steps, as defined in this SARP (Part A, Section 6.0) are important to safety.

- Doorstop Sample Carrier Systems are properly assembled. 


$$
\text { HNF-SD-TP-SARP-023 Rev, } 0
$$

- All acceptance criteria (Part A, Section 5.0) is met for the use of a new package.

- Operational (Part A, Section 6.0) and maintenance procedures (Part A, Section 8.0) are properly completed.

$Q A$ verification shall be included for each $Q \mathrm{~L} A-3$ and $\mathrm{B}-3$ operation and maintenance activity as described in Part $A$, Sections 6.0 and 8.0 .

7.4.5.1 Acceptance and Records. Acceptance of an activity shall be documented and approved by authorized facility QA/QC personnel per WHC-CM-4-2. Inspection documentation shall be maintained for the 1ife of the package or five years, whichever is longer.

\subsubsection{Test Control}

These requirements apply to activities associated with the testing of the Doorstop Sample Carrier System and associated hardware involving QL A-3 or designated $\mathrm{B}-3$ items. Testing shall be performed and documented per WHC-CM-4-2.

Tests required to verify conformance of package components to this SARP's requirements, and to demonstrate satisfactory performance for service shall be planned, performed, and documented. Characteristics to be tested and test methods to be employed shall be specified. Test results shall be documented, and their conformance with acceptance criteria shall be evaluated.

\subsubsection{Control of Measuring and Test Equipment}

The requirements for measuring and test equipment, contained in WHC-CM-4-2, apply to all equipment used to determine acceptability of Doorstop Sample Carrier System items, components, or activities, regardless of assigned QL.

\subsubsection{Control of Nonconforming Items}

Identification, documentation, evaluation and disposition of nonconforming items and activities shall be accomplished per WHC-CM-4-2, regardless of the assigned $\mathrm{QL}$.

Items procured or fabricated for the Doorstop Sample Carrier System or use in the package, shall be QC inspected prior to use for compliance with the purchase order, specification, and/or fabrication drawing. The cognizant engineer, with QA assistance, shall define the acceptance criteria.

\subsubsection{Corrective Action}

Nonconformance or conditions adverse to quality are evaluated as described in Part A, Section 7.4.8, and the need for corrective action is determined in accordance with WHC-CM-4-2. 


$$
\text { HNF-SD-TP-SARP-023 Rev. } 0
$$

\subsubsection{Quality Assurance Records and Document Control}

Records that furnish documentary evidence of quality shall be specified, prepared, and maintained per WHC-CM-4-2 and WHC-CM-3-5, Document Control and Records Management Manual. All documents used to perform and/or verify items or activities are controlled. Controlled documents include (but are not limited to) the following: drawings, specifications, purchase orders, plans and procedures to inspect and test, reports, quality verification reports, nonconformance reports, corrective action reports, the SARP, and operational and maintenance procedures.

\subsubsection{Audits}

Internal and external audit process are guided by, and shall be in accordance with WHC-CM-4-2.

\subsection{SARP CONTROL SYSTEM}

This SARP is a copy controlled supporting document to ensure that only up-to-date approved versions are used for transport. Any changes made to this SARP will be by engineering change notices, which are distributed to users through the Copy Control System and incorporated into the SARP.

Any review comment records produced during the initial release or subsequent changes will be on file with Packaging Engineering. 


$$
\text { HNF-SD-TP-SARP-023 Rev, } 0
$$

\subsection{MAINTENANCE}

\subsection{GENERAL REQUIREMENTS}

A maintenance program shall be followed to ensure the integrity of the $\mathrm{N}-55$ overpacks, DOT 208-L drums, Doorstop containers, and Doorstop sample containers. Gaskets, toggle clamps, and other components necessary for the safe and easy operation of the packaging shall be given regular inspection and repaired or replaced as necessary.

\subsection{MAINTENANCE REQUIREMENTS}

Maintenance frequency and acceptance requirements are based upon the QL of the component or activity. QL A-3 and B-3 components or activities are considered important to safety. Should the maintenance not be performed for QL $A-3$ and/or B-3 components, proper safety review and documentation is required.

Maintenance required for QL A-3 components is shown in Table A8-1.

Table A8-1. Quality Level A-3 Maintenance Requirements.

\begin{tabular}{|l|l|l|}
\hline \multicolumn{1}{|c|}{ Component/activity } & \multicolumn{1}{|c|}{ Frequency } & \multicolumn{1}{c|}{ Acceptance requirements } \\
\hline \hline Doorstop container leak test & Annually & ANSI N14.5 $5.81 \times 10^{-5} \mathrm{std}-\mathrm{cc} / \mathrm{s}$ \\
\hline Doorstop 0-ring replacement & Annually & Meeting drawing requirements \\
\hline $\begin{array}{l}\text { Doorstop container visual } \\
\text { inspection }\end{array}$ & Annually & $\begin{array}{l}\text { Meets drawing material requirements } \\
\text { not damaged such that containment would be jeopardized }\end{array}$ \\
\hline
\end{tabular}

ANSI = American National Standards Institute.

$Q A=$ Qual ity Assurance.

WHC = Westinghouse Hanford Company.

ANSI, 1987, American National Standard for Radioactive Materials - Leakage Tests on

Packages for Shipment, ANSI N14.5 American National Standards Institute, Inc.

Maintenance required for QL B-3 components is shown in Table A8-2.

Table A8-2. Quality Level B-3 Maintenance Requirements.

\begin{tabular}{|c|c|c|}
\hline Component activity & Frequency & Acceptance requirements \\
\hline $\begin{array}{l}\text { Dor } 208-L \text { drum gasket } \\
\text { replacement }\end{array}$ & $\begin{array}{l}\text { Annually and/or as } \\
\text { required }\end{array}$ & $0.95 \mathrm{~cm}$ ( $\%$ in.) tubular NEOZAN ${ }^{\prime}$ gasket \\
\hline $\begin{array}{l}\text { N-55 overpack gasket } \\
\text { repl acement }\end{array}$ & $\begin{array}{l}\text { Annually and/or as } \\
\text { required }\end{array}$ & $\begin{array}{l}\text { Neoprene gasket material } 0.64 \mathrm{~cm}(1 / \text { in. }) \text { to } 1.3 \mathrm{~cm} \\
(1 / 2 \text { in.) thick. Meet applicable } \mathrm{N}-55 \text { overpack } \\
\text { drawing requirements. }\end{array}$ \\
\hline $\begin{array}{l}\text { Lifting fixture load } \\
\text { test }\end{array}$ & Annually & Hanford site Hoisting and Rigging Manual (RL 1993) \\
\hline
\end{tabular}




$$
\text { HNF-SD-TP-SARP-023 ReV. } 0
$$

Maintenance required for $Q L C-3$ components is 1 isted in Table A8-3.

Table A8-3. Quality Leve1 C-3 Maintenance Requirements.

\begin{tabular}{|l|l|l|}
\hline \multicolumn{1}{|c|}{ Component } & \multicolumn{1}{|c|}{ Frequency } & \multicolumn{1}{c|}{ Acceptance requirements } \\
\hline \hline Tiedown straps visual inspection & Annully & Replace if frayed or worn \\
\hline $\begin{array}{l}\text { Doorstop sample container visual } \\
\text { inspection }\end{array}$ & Every 2 years & \\
\hline $\begin{array}{l}\text { N-55 overpack toggle clamps } \\
\text { functional inspection (lubricate } \\
\text { and visual ly inspect) }\end{array}$ & Annually & $\begin{array}{l}\text { Replace if clamps are bent or } \\
\text { damaged to the extent that proper } \\
\text { latching would be impaired }\end{array}$ \\
\hline
\end{tabular}

\subsection{DOCUMENTATION}

Maintenance from Part A, Section 8.2 , shall be documented in procedures and/or inspection checklists and verified by cognizant facility Quality Assurance/QC. Records of inspection and maintenance for the Doorstop Sample Carrier System shall be retained for the life of the packaging system or five years, whichever is longer. 
HNF-SD-TP-SARP-023 Rev. 0

\subsection{REFERENCES}

10 CFR 71, 1995, "Packaging and Transportation of Radioactive Materials," Code of Federal Regulations, as amended.

49 CFR 172, 1995, "Hazardous Materials Table, Special Provisions, Hazardous Materials Communications, Emergency Response Information, and Training Requirements," Code of Federal Regulations, as amended.

49 CFR 173, 1995, "Shippers--General Requirements for Shipments and Packagings," Code of Federal Regulations, as amended.

ANSI, 1987, American National Standard for Radioactive Materials - Leakage Test on Packages for Shipment, ANSI N14.5, American National Standards Institute, New York, New York.

ASME, 1994, Quality Assurance Program Requirements for Nuclear Facilities, ASME NQA-1, American Society for Mechanical Engineers, New York, New York.

ASME, 1995, American Society of Mechanical Engineers Boiler and Pressure Vessel Code, American Society of Mechanical Engineers, New York, New York.

NRC, 1991, Fracture Toughness Criteria of Base Material for Ferritic Steel Shipping Cask Containment Vessels with a Maximum Wall Thickness of 4 Inches, Regulatory Guide 7.11, U.S. Nuclear Regulatory Commission, Washington, D.C.

NRC, 1994, U.S. Nuclear Regulatory Commission Certificate of Compliance for Radioactive Materials Packages, Certificate Number 9070, Rev. 12, package identification number USA/9070/B(U), U.S. Nuclear Regulatory Commission, Washington, D.C., December 20, 1994.

RL, 1993, Hanford Site Hoisting and Rigging Manual, DOE-RL-92-36, U.S. Department of Energy, Richland Operations Office, Richland, Washington.

RL, 1994, Hanford Site Radiological Control Manual, HSRCM-1, U.S. Department of Energy, Richland Operations Office, Richland, Washington.

WHC-CM-2-14, Hazardous Material Packaging and Shipping, Westinghouse Hanford Company, Richland, Washington.

WHC-CM-4-2, Quality Assurance Manual, Westinghouse Hanford Company, Richland, Washington.

WHC-CM-6-1, Standard Engineering Practices, Westinghouse Hanford Company, Richland, Washington.

WHC, 1994, Report on Equivalent Safety for Transportation and Packaging of Radioactive Materials, WHC-SD-TP-RPT-001, Rev. 0, Westinghouse Hanford Company, Richland, Washington. 


\section{HNF-SD-TP-SARP-023 Rev. 0}

WHC, 1995, Quality Assurance Program Plan for the Hazardous Materials Transportation and Packaging Program, WHC-IP-0705, Westinghouse Hanford Company, Richland, Washington.

WHC, 1996, Tank Waste Compositions and Atmospheric Dispersion Coefficients for Use in Safety Analysis Consequence Assessments, WHC-SD-WM-SARR-016, Rev. 2, Westinghouse Hanford Company, Richland, Washington. 
HNF-SD-TP-SARP-023 Rev. 0

\subsection{APPENDICES}

\subsection{DRAWINGS}


HNF-SD-TP-SARP-023 Rev, 0

This page intentionally left blank.

Al0-2 
HNF-SD-TP-SARP-023

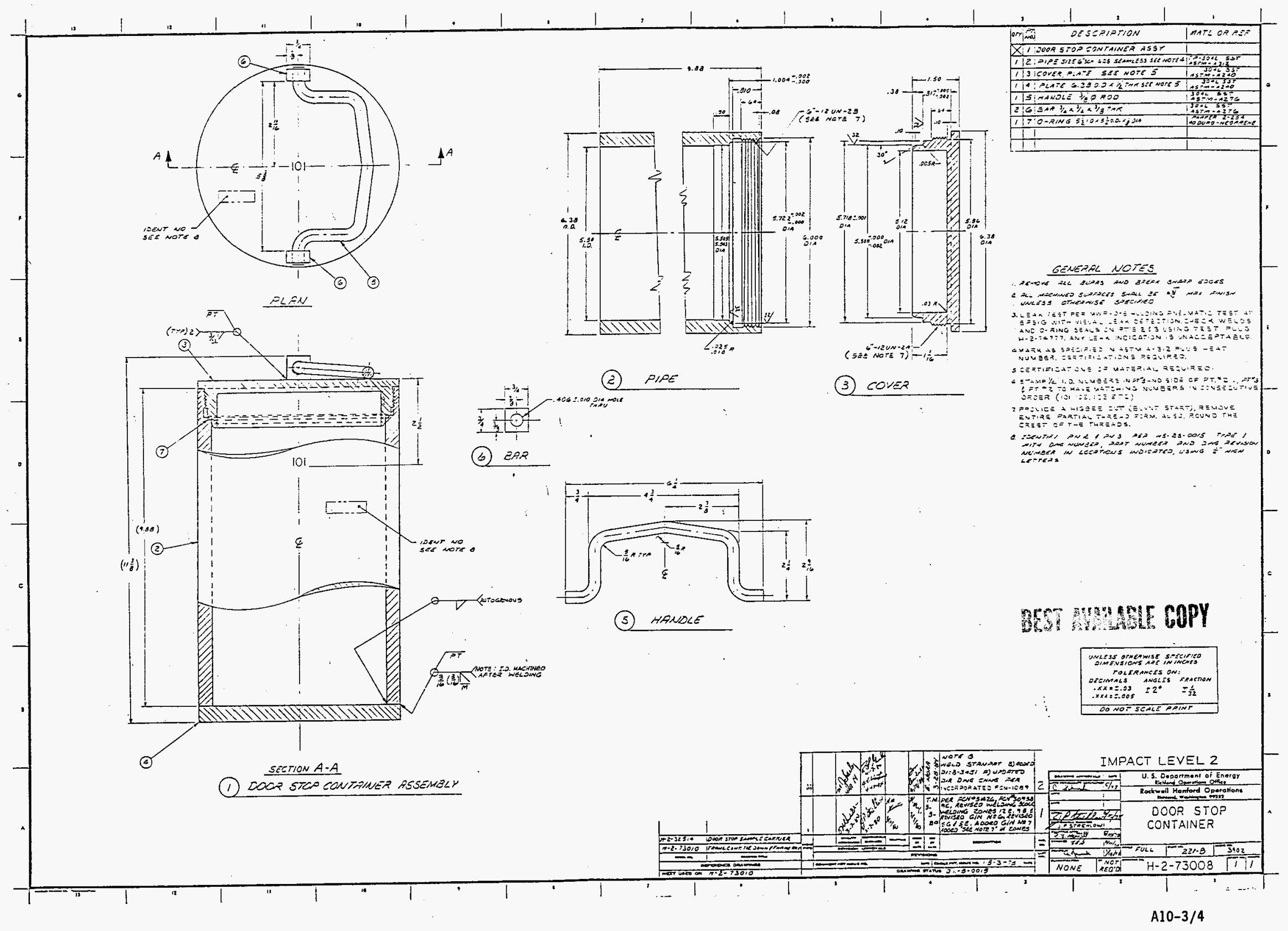


THIS PAGE INTENTIONALLY LEFT BLANK 


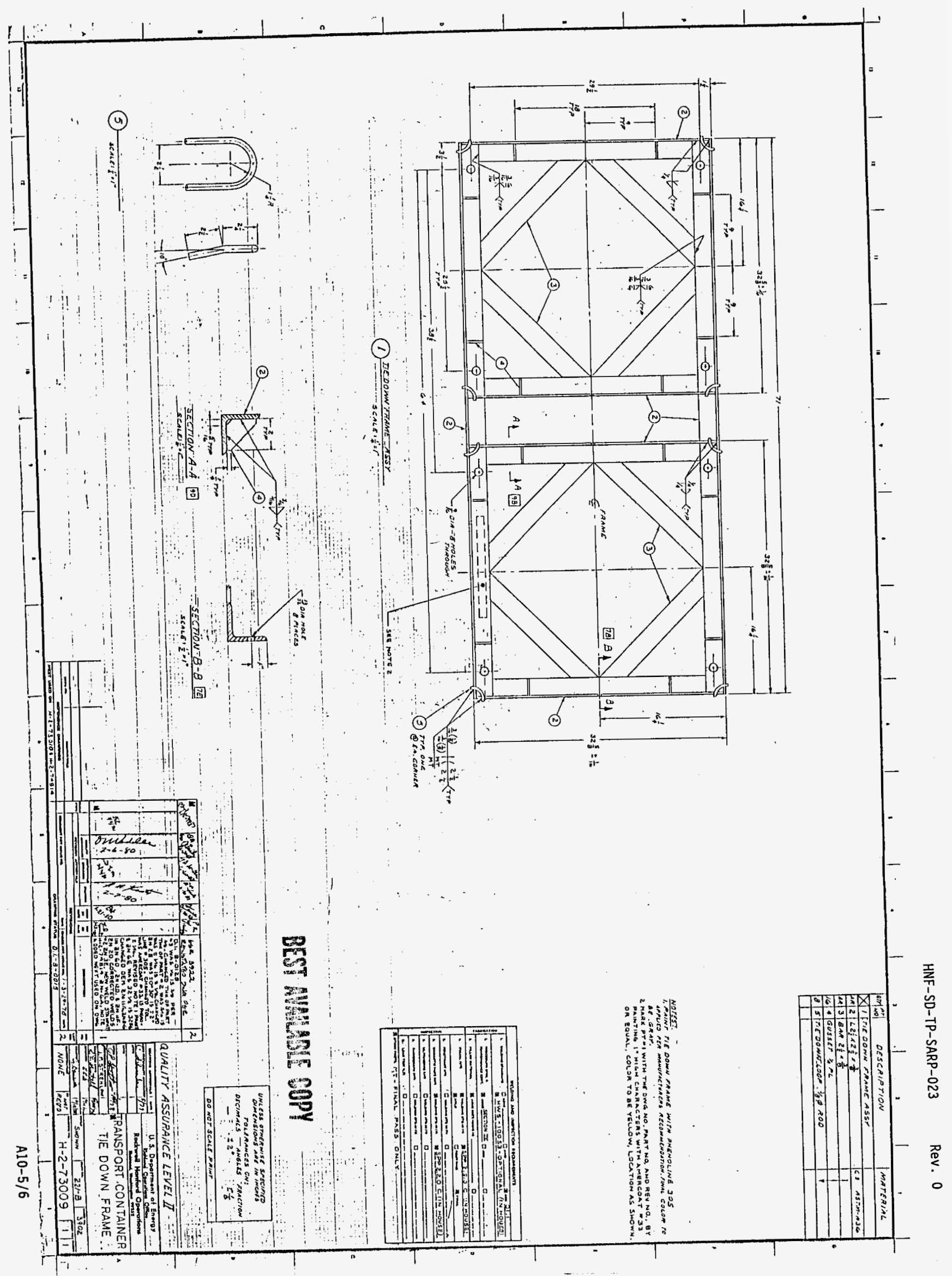





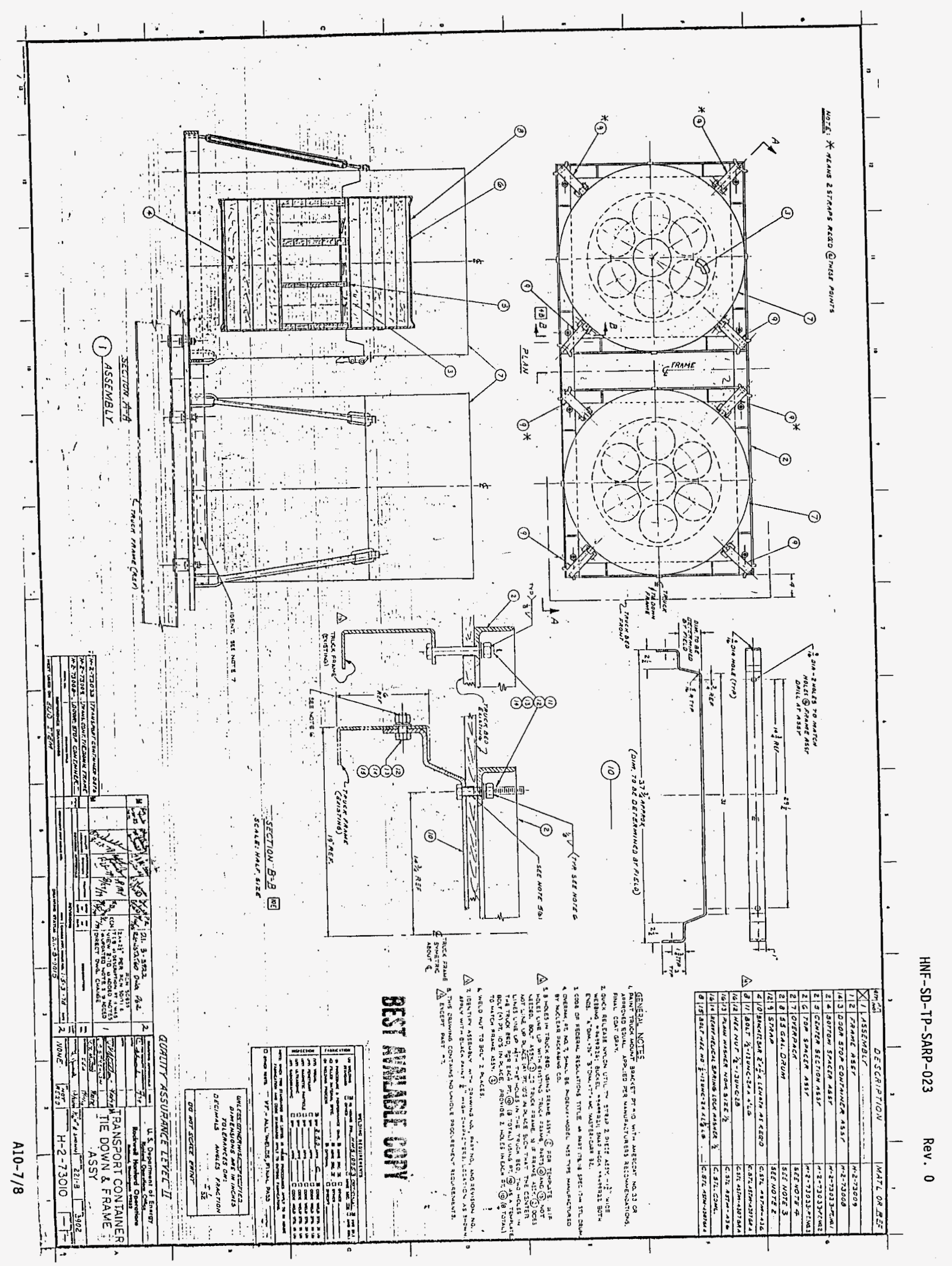


THIS PAGE INTENTIONALLY

LEFT BLANK 


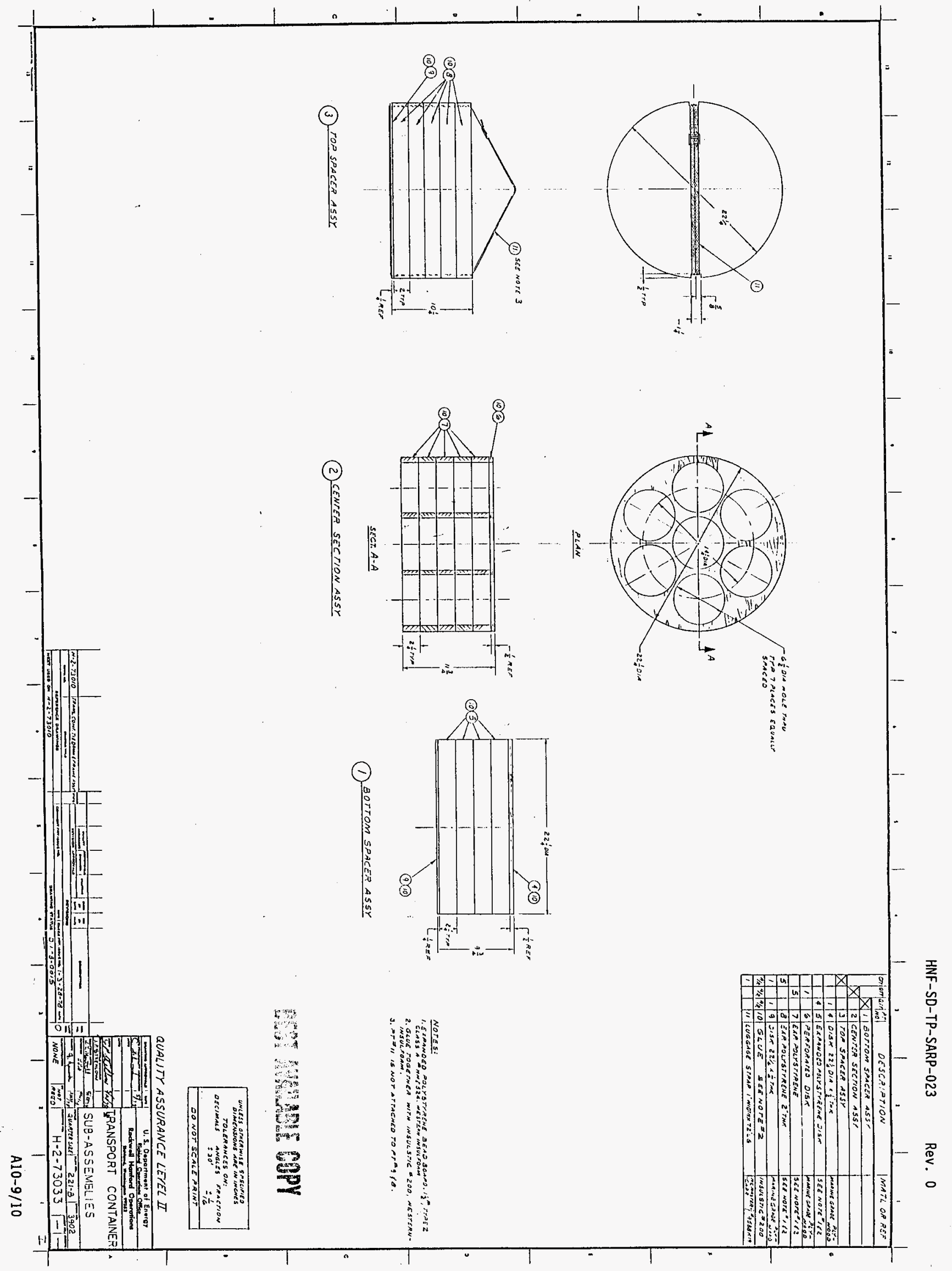


THIS PAGE INTENTIONALLY LEFT BLANK 


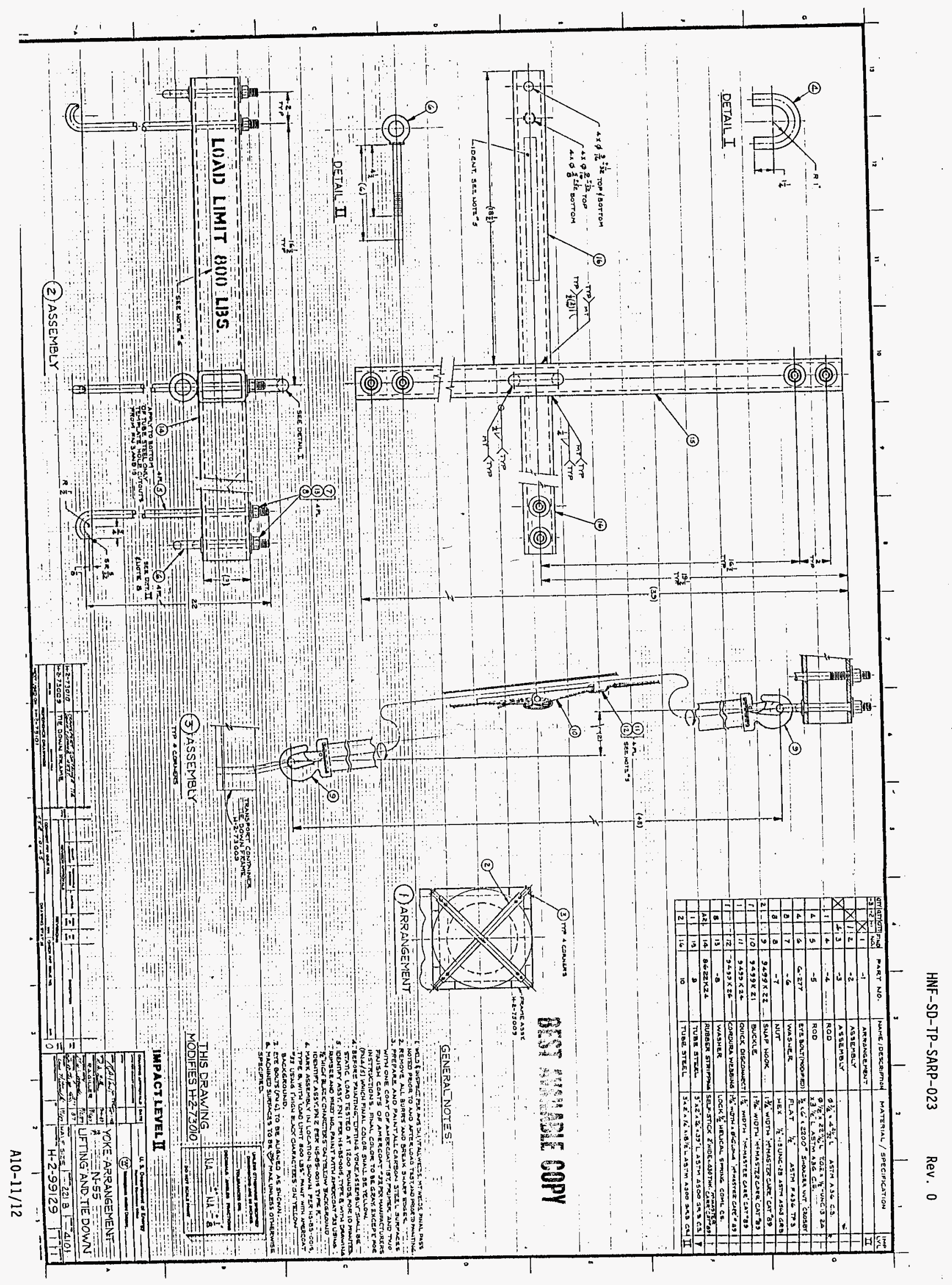


THIS PAGE INTENTIONALLY LEFT BLANK 
HNF-SD-TP-SARP-023 ReV. 0

PART B: PACKAGE EVALUATION

\subsection{INTRODUCTION}

\subsection{SAFETY EVALUATION METHODOLOGY}

The safety of the Doorstop Sample Carrier System has been shown by drop test comparison and analysis to meet the intent of Title 10, Code of Federal Regulations, Part 71 (10 CFR 71) Type B packaging regulations for onsite requirements.

\subsection{EVALUATION SUMMARY AND CONCLUSIONS}

This evaluation compares the packaging's structural, thermal, containment, shielding, and criticality design features with the performance criteria found in 10 CFR 71 Type $B$ packaging requirements. The criteria for design acceptance of a 10 CFR 71 Type B packaging are met for the Doorstop Sample Carrier System containing either 1iquid or solid contents. Additional operational requirements were developed to permit shipment of loads in which the radiation levels exceed normal operating levels. These controls establish an equivalent level of safety.

\subsubsection{Contents}

The allowable contents of the Doorstop Sample Carrier System are based upon the radionuclide table in Part $B$, Section 2.1. The maximum quantity of radioactive contents is $875 \mathrm{~mL}$. The maximum is based on $125 \mathrm{~mL}$ per Doorstop container, seven Doorstop containers per $\mathrm{N}-55$ overpack. The maximum expected source term corresponds to $5.0 \mathrm{~A}_{2} \mathrm{~s}$, and the worst-case source term to $93 \mathrm{~A}_{2} \mathrm{~s}$ (see Part B, Section 2.1). The packaging system is limited to $0.74 \mathrm{TBq}$ $(20 \mathrm{Ci})$ of plutonium and $15 \mathrm{~g}$ of fissile material.

\subsubsection{Radiological Risk}

A radiological risk evaluation (Part B, Section 3.0) is not performed for the Doorstop Sample Carrier System because it has been demonstrated to meet the performance requirements of the U.S. Department of Transportation (DOT)/ U.S. Nuclear Regulatory Commission (NRC) for Type B packagings. Additional operational requirements were developed to permit shipment of loads in which the radiation levels exceed normal operating levels. 


$$
\text { HNF-SD-TP-SARP-023 Rev. } 0
$$

\subsubsection{Containment}

Containment is provided by the Doorstop container. An additional containment boundary is the DOT specification or performance-oriented 208-L (55-gal) drum (DOT 208-L drum). The containment boundary meets the requirements of the American National Standards Institute (ANSI) N14.5, American National Standard for Radioactive Materials - Leakage Tests on Packages for Shipment (ANSI 1987), with a leakage rate of less than or equal to $5.81 \times 10^{-5} \mathrm{std}-\mathrm{cc} / \mathrm{s}$.

\subsubsection{Shielding}

Shielding is provided by the stainless steel Doorstop container and, at times, additional shielding is provided by stainless steel or lead-lined inserts. The external dose rate limits direct the amount of administrative controls required by operations. The source terms evaluated in the shielding section (Part B, Section 5.0) were conservatively developed to allow transport of samples from all onsite radioactive waste tanks. There are two source terms evaluated: one is the worst-case solid source term, and one is the maximum expected. For loads where the radiation levels exceed regulatory established limits for offsite shipment, additional operational limits are used to ensure worker safety. When needed, these limits are met through the use of shielding on the transport vehicle, external to the package.

\subsubsection{Criticality}

A criticality evaluation (Part B, Section 6.0) is not required for the Doorstop Sample Carrier System since the contents are limited to $15 \mathrm{~g}$ fissile. Packages containing $15 \mathrm{~g}$ or less of fissile material are exempt from fissile material classification and are not required to meet the fissile material standards or 10 CFR 71.55 and 71.59 (10 CFR 71.53).

\subsubsection{Structural}

It was determined through testing and analysis (Part B, Section 7.0) that the Doorstop Sample Carrier System meets 10 CFR 71 normal conditions of transport (NCT) and hypothetical accident conditions (HAC) design criteria.

The drop testing performed (Adkins 1995) demonstrates minor damage wi11 occur from a $9-\mathrm{m}(30-\mathrm{ft})$ or $1.2-\mathrm{m}(4-\mathrm{ft})$ drop. A conservative evaluation determined that the Doorstop Sample Carrier System could receive a maximum of $190 \mathrm{gs}$ during a side drop. This was determined based on the condition of the $\mathrm{N}-55$ overpack from a similar drop test. The containment of the Doorstop container is not compromised due to this maximum $g$-loading as shown by analys is (Part B, Section 7.0).

\subsubsection{Thermal}

The Doorstop container payload for the worst-case solid payload is $6.9 \times 10^{-2} \mathrm{~W}$. If the seven Doorstop containers in the Doorstop Sample Carrier 
HNF-SD-TP-SARP-023 Rev. 0

System were loaded to the maximum heat load, the value would be $4.9 \times 10^{-1} \mathrm{~W}$. This low thermal generation rate from the payload does not impose any significant heat into the thermal calculations. The calculations were performed assuming a worst-case $3-W$ payload per Doorstop container, and demonstrate that during both normal and accident conditions the Doorstop Sample Container System meets the acceptance criteria (Part B, Section 8.0).

\subsubsection{Gas Generation}

The maximum gas generation rate based on the worst-case source term creates a gas generation rate of $219 \mathrm{cc} / \mathrm{h}$ per $125-\mathrm{mL}$ payload (Part $B$, Section 9.0). Operational limits that identify the maximum period the loaded Doorstop container should remain sealed are established for various loads. The limits are based on ensuring that the lower flammability limit is not exceeded.

\subsubsection{Tiedown System}

The tiedown system, when evaluated against the current $0.5 \mathrm{~g}$ to working load limit, meets the requirements of 49 CFR 393 with positive margins of safety (Part B, Section 10.0). There are no tiedown devices that are a structural part of the package. Therefore, 10 CFR 71 and 49 CFR 173 tiedown requirements are not required to be met.

\subsection{REFERENCES}

10 CFR 71, 1995, "Packaging and Transportation of Radioactive Material," Code of Federal Regulations, as amended.

49 CFR 173, 1995, "Transportation," Code of Federal Regulations, as amended.

49 CFR 393, 1995, "Parts and Accessories for Safe Operation," Code of Federal Regulations, as amended.

Adkins, H. E., 1995, Pig Shipping Container Test Report, WHC-SD-TP-TR-002, Rev. O, Westinghouse Hanford Company, Richland, Washington.

ANSI, 1987, American Nationa7 Standard for Radioactive Materials - Leakage Tests on Packages for Shipment, ANSI N14.5, American National Standards Institute, New York, New York. 
HNF-SD-TP-SARP-023 Rev. 0

This page intentionally left blank.

B1-4 
HNF-SD-TP-SARP-023 Rev. 0

\subsection{CONTENTS EVALUATION}

\subsection{CHARACTERIZATION}

The Doorstop Sample Carrier System will be used to transport liquid or solid tank waste samples. The solid tank waste radionuclide composition from WHC-SD-WM-SARR-016 (WHC 1996) bounds the liquid tank waste for all areas considered in this safety analysis report for packaging (SARP); i.e., shielding, dose consequence, thermal, gas generation, and criticality. Therefore, the Doorstop container source terms were established using the solid tank waste activity concentrations. The worst-case solid tank waste activity concentrations used to derive the source term are listed in Table B2-1.

The worst-case source term was developed by first determining the maximum activity concentration of each radionuclide using the existing sample data from all of the tanks. The maximum sample activity concentrations are documented in WHC-SD-WM-SARR-016 (WHC 1996). These activity concentrations were then assumed to exist in a single tank, thus creating a worst-case source term. Consequently, it is not possible to have a sample that contains all of the maximum radionuclide quantities because they are from several different tanks. Historically, the dose rates on the surface of the Doorstop Sample Carrier System have been less than $2 \mathrm{mSv} / \mathrm{h}(200 \mathrm{mrem} / \mathrm{h})$. Therefore, a second, "maximum expected" source term was developed based on a 200 -mrem/h dose rate at the N-55 overpack surface. Administrative controls are developed (Part $A$, Section 6.5) to allow transport up to the worst-case scenario, ensuring that a)1 samples are transported according to WHC-CM-2-14, Hazardous Material Packaging and Shipping.

The shielding analysis (Part B, Section 5.0) indicated that $875 \mathrm{~mL}$ (29.6 oz) of the worst-case solid tank waste results in a maximum surface dose rate of $37 \mathrm{mSv} / \mathrm{h}(3700 \mathrm{mrem} / \mathrm{h})$, which is a factor of 18.5 times greater than $2 \mathrm{mSv} / \mathrm{h}(200 \mathrm{mrem} / \mathrm{h})$. The maximum expected source term was derived using the worst-case solid activity concentrations (Table B2-1) and reducing the total activity of each radionuclide to yield a surface dose rate of $2 \mathrm{mSv} / \mathrm{h}$ $(200 \mathrm{mrem} / \mathrm{h})$ for a $875-\mathrm{mL}(29.6-0 \mathrm{z})$ sample size. A scaling factor of 0.047 (875 $\mathrm{mL} \times$ Table $B 2-1 \mathrm{Ci} / \mathrm{L}$ values/18.5) was applied to the activity concentrations from Table B2-1 to produce $2 \mathrm{mSv} / \mathrm{h}(200 \mathrm{mrem} / \mathrm{h})$. The second source term corresponds to $875 \mathrm{~mL}(29.6 \mathrm{oz})$ of the worst-case solids source term. Both source terms are listed in Table B2-1.

The heat generation rate for $875 \mathrm{~mL}(29.6 \mathrm{oz})$ of the maximum expected source term is $2.6 \times 10^{-2} \mathrm{~W}$ and for the $875 \mathrm{~mL}(29.6 \mathrm{oz})$ of the worst-case source term is $4.8 \times 10^{-1} \mathrm{~W}$ as can be seen in the RADCALC output in Part B, Section 9.0. The maximum expected source term corresponds to $5.0 \mathrm{~A}_{2} \mathrm{~s}$, and the worst-case source term contains $93 \mathrm{~A}_{2} \mathrm{~s}$ as shown in Table B2-1. Therefore, the package contains Type $B$ quantities of radioactive material. 
Table B2-1. Solid Tank Waste Source Terms for the Doorstop.

\begin{tabular}{|c|c|c|c|c|c|c|c|c|}
\hline Nucl ide & $\begin{array}{c}\text { Worst-case } \\
\text { solids } \\
\text { activity } \\
\text { concentration } \\
\text { ei }(\mathrm{L} / \mathrm{L})\end{array}$ & $A_{2}(C i)^{a}$ & $\begin{array}{c}875 \mathrm{~mL} \\
(29.6 \mathrm{oz}) \\
\text { maximum } \\
\text { expected } \\
(\mathrm{Bg})\end{array}$ & $\begin{array}{c}875 \mathrm{~mL} \\
(29.6 \mathrm{oz}) \\
\text { maximum } \\
\text { expected } \\
\text { (Ci }) \\
\end{array}$ & $A_{2} s$ & $\begin{array}{c}875 \mathrm{~mL} \\
(29.6 \mathrm{oz}) \mathrm{c} \\
\text { worst case } \\
(\mathrm{Bq})\end{array}$ & $\begin{array}{c}875 \mathrm{~mL} \\
(29.6 \mathrm{oz}) \\
\text { worst case } \\
\text { (Ci) }\end{array}$ & $A_{2} S$ \\
\hline${ }^{14} \mathrm{C}$ & $4.3 \mathrm{E}-06$ & $5.4 E+01$ & $7.4 E+03$ & $2.0 \mathrm{E}-07$ & 3.7 E-09 & $1.4 E+05$ & $3.8 E-06$ & $7.0 \mathrm{E}-08$ \\
\hline${ }^{60} \mathrm{Co}$ & $1.3 \mathrm{E}-02$ & $1.1 E+01$ & $2.3 E+07$ & $6.1 E-04$ & $5.7 \mathrm{E}-05$ & $4.1 E+08$ & $1.1 \mathrm{E}-02$ & $1.0 \mathrm{E}-03$ \\
\hline${ }^{79} \mathrm{Se}$ & $4.6 \mathrm{E}-07$ & $5.4 E+01$ & $8.1 E+02$ & $2.2 \mathrm{E}-08$ & $4.1 \mathrm{E}-10$ & $1.5 \mathrm{E}+04$ & $4.0 \mathrm{E}-07$ & 7.4 E- 09 \\
\hline${ }^{90} \mathrm{sr}$ & $7.8 \mathrm{E}+01$ & $2.7 \mathrm{E}+00$ & $1.4 E+11$ & $3.7 \mathrm{E}+00$ & $1.4 E+00$ & $2.5 E+12$ & $6.8 E+01$ & $2.5 \mathrm{E}+01$ \\
\hline $90 Y^{f}$ & $7.8 \mathrm{E}+01$ & $5.4 \mathrm{E}+00$ & $1.4 E+11$ & $3.7 \mathrm{E}+00$ & 0.0 & $2.5 \mathrm{E}+12$ & $6.8 E+01$ & 0.0 \\
\hline${ }^{99} \mathrm{TC}$ & 3.2 E-01 & $2.4 E+01$ & $5.6 \mathrm{E}+08$ & $1.5 \mathrm{E}-02$ & $6.2 E-04$ & 1.0 E+10 & $2.8 \mathrm{E}-01$ & $1.2 \mathrm{E}-02$ \\
\hline${ }^{106} \mathrm{Ru}$ & $1.9 \varepsilon-06$ & $5.4 E+00$ & $3.3 \mathrm{E}+03$ & 8.9 E-08 & $1.7 \mathrm{E}-08$ & $6.3 \mathrm{E}+04$ & 1.7 E-06 & $3.1 \mathrm{E}-07$ \\
\hline${ }^{106} 6_{R h} f$ & $1.9 \mathrm{E}-06$ & 0.0 & $3.3 E+03$ & $8.9 E-08$ & 0.0 & $6.3 E+04$ & 1.7 E-06 & 0.0 \\
\hline${ }^{125} \mathrm{sb}$ & $4.9 \mathrm{E}-03$ & $2.4 E+01$ & $8.5 E+06$ & $2.3 \mathrm{E}-04$ & $9.5 \mathrm{E}-0.06$ & $1.6 E+08$ & $4.3 \mathrm{E}-03$ & $1.8 \mathrm{E}-04$ \\
\hline $129_{I}$ & $1.7 E-04$ & Unl imited & $3.0 E+05$ & 8.0 E-06 & 0.0 & $5.6 \mathrm{E}+06$ & 1.5 E-04 & 0,0 \\
\hline${ }^{134} \mathrm{Cs}$ & $2.5 \mathrm{E}-04$ & $1.4 \mathrm{E}+01$ & $4.4 E+05$ & $1.2 \mathrm{E}-05$ & 8.9 E- 07 & 8.1E+06 & 2.2 E- 04 & $1.6 \mathrm{E}-05$ \\
\hline${ }^{137} \mathrm{Cs}$ & $2.7 E+00$ & $1.4 E+01$ & $4.8 E+09$ & $1.3 \mathrm{E}-01$ & $9.6 E-03$ & $8.9 E+10$ & $2.4 \mathrm{E}+00$ & $1.8 \mathrm{E}-01$ \\
\hline${ }^{137 m_{1}}{ }^{f}$ & $2.6 E+00$ & 0.0 & $4.4 E+09$ & 1.2 E-01 & 0.0 & $8.5 E+10$ & $2.3 \mathrm{E}+00$ & 0.0 \\
\hline${ }^{144} \mathrm{Ce}$ & 9.2 E-09 & $5.4 E+00$ & $1.6 \mathrm{E}+01$ & $4.3 \mathrm{E}-10$ & $8.0 \mathrm{E}-11$ & $3.0 \mathrm{E}+02$ & 8.1E-09 & 1.5 E-09 \\
\hline${ }^{144} \mathrm{Pr}^{\mathrm{f}}$ & $9.2 \in-09$ & 0.0 & $1.6 E+01$ & $4.3 \mathrm{E}-10$ & 0.0 & $3.0 \mathrm{E}+02$ & 8.1 E-09 & 0.0 \\
\hline${ }^{154} \mathrm{EU}$ & $3.0 \mathrm{E}-01$ & $1.4 E+01$ & $5.2 E+08$ & $1.4 \mathrm{E}-02$ & $1.0 \mathrm{E}-03$ & $9.6 \mathrm{E}+09$ & $2.6 \mathrm{E}-01$ & $1.9 \mathrm{E}-02$ \\
\hline${ }^{155} \mathrm{Eu}$ & 1.4 E-04 & $5.4 E+01$ & $2.4 E+05$ & $6.6 \mathrm{E}-06$ & $1.2 \mathrm{E}-07$ & $4.4 E+06$ & $1.2 \mathrm{E}-04$ & 2.2 E-06 \\
\hline${ }^{237} \mathrm{~Np}$ & $2.7 \mathrm{E}-02$ & $5.4 \mathrm{E}-03$ & $4.8 E+07$ & $1.3 E-03$ & $2.4 E-01$ & $8.9 E+08$ & $2.4 \mathrm{E}-02$ & $4.4 \mathrm{E}+00$ \\
\hline${ }^{238} \mathrm{Pu}$ & $5.1 \mathrm{E}-03$ & $5.4 E-03$ & $8.9 E+06$ & $2.4 E-04$ & $4.4 \mathrm{E}-02$ & $1.7 \mathrm{E}+08$ & $4.5 \mathrm{E}-03$ & $8.3 \mathrm{E}-01$ \\
\hline${ }^{239} \mathrm{Pu}$ & $4.3 \mathrm{E}-02$ & $5.4 E-03$ & $7.4 E+07$ & $2.0 \mathrm{E}-03$ & $3.7 E-01$ & $1.4 E+09$ & $3.8 \mathrm{E}-02$ & $7.0 \mathrm{E}+00$ \\
\hline $240 \mathrm{Pu}^{\mathrm{d}}$ & $4.3 \varepsilon-02$ & $5.4 E-03$ & $7.4 E+07$ & $2.0 \mathrm{E}-03$ & $3.7 \mathrm{E}-01$ & $1: 4 E+09$ & $3.8 \mathrm{E}-02$ & $7.0 \mathrm{E}+00$ \\
\hline${ }^{241} \mathrm{Pu}$ & $1.0 \mathrm{E}-01$ & $2.7 \mathrm{E}-01$ & $1.7 E+08$ & $4.7 \mathrm{E}-03$ & $1.7 \mathrm{E}-02$ & $3.3 E+09$ & $8.8 \mathrm{E}-02$ & $3.3 E-01$ \\
\hline${ }^{241_{\mathrm{Am}}}$ & $3.0 \mathrm{E}-01$ & $5.4 \mathrm{E}-03$ & $5.2 E+08$ & $1.4 \mathrm{E}-02$ & $2.6 E+00$ & $9.6 \mathrm{E}+09$ & $2.6 E-01$ & $4.8 E+01$ \\
\hline${ }^{242} \mathrm{~cm}$ & 5.4 E-09 & $2.7 \varepsilon-01$ & $9.3 E+00$ & $2.5 E-10$ & $9.3 E-10$ & $1.7 E+02$ & $4.7 E-09$ & 1.7 E-08 \\
\hline${ }^{244} \mathrm{~cm}$ & $1.6 \mathrm{E}-03$ & $1.1 \mathrm{E}-02$ & $2.8 \mathrm{E}+06$ & $7.5 E-05$ & $6.9 \mathrm{E}-03$ & $5.2 \mathrm{E}+07$ & $1.4 \mathrm{E}-03$ & 1.3 E- 01 \\
\hline Totals & $1.6 E+02$ & $\ldots$ & $2.9 E+11$ & $7.7 \mathrm{E}+00$ & $5.0 E+00$ & $5.3 E+12$ & $1.4 E+02$ & $9.3 \mathrm{E}+01$ \\
\hline
\end{tabular}

${ }^{a}{ }_{A}$ values taken from 49 CFR 173.435, 1995, "Shippers--General Requirements for Shipments and Packagings," Code of Federal Regulations, as amended.

baximum expected source term derived using the solid tank waste activity concentrations (Ci/L) and multiplying by the factor 0.047 such that the total Doorstop radioactive loading results in a dose rate less than $2 \mathrm{mSv} / \mathrm{h}(200 \mathrm{mrem} / \mathrm{h})$ at the package surface.

CHorst-case source term assumes $875 \mathrm{~mL}(29.6 \mathrm{oz})$ of solid tank waste.

d240 Pu conservatively set equal to $239 \mathrm{Pu}$.

Vatues taken from WHC-SD-WM-SARR-016, Rev. 2 (WHC 1996). Daughters calculated using ORIGEN2.

${ }^{f}$ This radionuclide is a daughter as defined in 49 CFR 173.433; therefore, its activity was set to 0 for the $A_{2}$ calculations.

WHC, 1996, Tank Waste Compositions and Atmospheric Dispersion Coefficients for Use in Safety Analys is Consequence Assessments, WHC-SD-WM-SARR-016, Rev. 2, Westinghouse Hanford Company, Richland, Washington. 
HNF-SD-TP-SARP-023 Rev. 0

\subsection{RESTRICTIONS}

The Doorstop Sample Carrier System is limited to $875 \mathrm{~mL}(29.6 \mathrm{oz})$ of tank waste. The Doorstop container is limited to $125 \mathrm{~mL}(4.3 \mathrm{oz})$ of tank waste.

\subsection{SIZE AND WEIGHT}

The maximum weight of the Doorstop container contents (sample and container) is $14.5 \mathrm{~kg}(32 \mathrm{1b})$. The volumes normally found in the various configurations are identified in Table B2-1. Other volumes are permitted providing they do not exceed $125 \mathrm{~mL}(4.3 \mathrm{oz})$.

Table B2-2. Inner Packaging Normally Used in Doorstop Container.

\begin{tabular}{|l|l|}
\hline \multicolumn{1}{|c|}{ Packaging } & \multicolumn{1}{|c|}{ Usual volumes } \\
\hline \hline Doorstop sample carrier, stainless steel & $0.5,1.0$ or $1.6 \mathrm{~mL}$ \\
\hline Doorstop sample carrier, stainless steel clad lead & $0.5,1.0$ or $1.6 \mathrm{~mL}$ \\
\hline Lead pak cylinder & Less than $70 \mathrm{~mL}$ \\
\hline Bottled samples & No more than $125 \mathrm{~mL}$ \\
\hline
\end{tabular}

\subsection{CONCLUSIONS}

The two source terms evaluated ensure that the worst-case possible source term has been evaluated as a payload for the Doorstop Sample Carrier System.

\subsection{REFERENCES}

49 CFR 173, 1995, "Shippers--General Requirements for Shipments and Packagings," Code of Federal Regulations, as amended.

WHC-CM-2-14, Hazardous Material Packaging and Shipping, Westinghouse Hanford Company, Richland, Washington.

WHC, 1996, Tank Waste Compositions and Atmospheric Dispersion Coefficients for Use in Safety Analysis Consequence Assessments, WHC-SD-WM-SARR-016, Rev. 2, Westinghouse Hanford Company, Richland, Washington. 
HNF-SD-TP-SARP-023 Rev. 0

This page intentionally left blank.

B2-4 


$$
\text { HNF-SD-TP-SARP-023 Rev. } 0
$$

\subsection{RADIOLOGICAL RISK EVALUATION}

\subsection{INTRODUCTION}

A radiological risk evaluation is not required for the Doorstop Sample Carrier system since it is shown to meet the performance standards of the DOT/NRC regulations. 
HNF-SD-TP-SARP-023 Rev. 0

This page intentionally left blank. 
HNF-SD-TP-SARP-023 Rev. 0

\subsection{CONTAINMENT EVALUATION}

\subsection{INTRODUCTION}

The Doorstop Sample Carrier System meets the leaktight criteria of ANSI N14.5 (ANSI 1987) and maintains containment of the payload through NCT and HAC. Leak rate calculations were performed per ANSI N14.5 (ANSI 1987) to determine the leak rate acceptance criteria based on the payload. As shown in Part B, Section 4.7, the allowable leak rate is much greater than leaktight. Therefore, there is a significant amount of conservatism in the design of the Doorstop Sample Carrier System for maintaining containment of the payload.

The Doorstop container utilizes a Neoprene ${ }^{1}$ containment gasket. It has been shown by annual leak testing and analysis that containment will be maintained through all normal and accident conditions of transport.

\subsection{CONTAINMENT SOURCE SPECIFICATION}

The containment source is based on the worst-case, all-solid, source term from all waste tanks (Part B, Section 2.0). The Doorstop Sample Carrier System is used for transporting liquid tank samples, and therefore this source term conservatively represents the payload.

\subsection{NORMAL TRANSFER CONDITIONS}

\subsubsection{Conditions To Be Evaluated}

The conditions to be evaluated for normal conditions include hot and cold environmental conditions, pressurization, the 1.2-m (4-ft) drop onto an unyielding surface, and vibration normally incident to transport. The 1.2-m $(4-\mathrm{ft})$ drop is enveloped by the $9-\mathrm{m}(30-\mathrm{ft})$ drop; therefore, the calculations referred to are the $9-\mathrm{m}(30-\mathrm{ft})$ drop calculations. The evaluations will consider the loading effects on the containment boundary of the Doorstop container from these scenarios.

\subsubsection{Containment Acceptance Criteria}

Containment is maintained during NCT. The acceptance criteria is $5.81 \times 10^{-5} \mathrm{std}-\mathrm{cc} / \mathrm{s}$ per Part B, Section 4.7. The NCT stresses are evaluated and compared with American Society of Mechanical Engineers (ASME) Boiler and Pressure Vesse7 Code (BPVC), Section VIII (ASME 1995), allowables to demonstrate containment has been maintained, based on analysis.

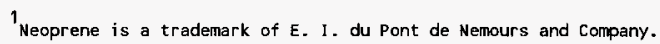




$$
\text { HNF-SD-TP-SARP-023 Rev. } 0
$$

\subsubsection{Containment Model}

The containment model used for the environmental conditions, pressurization, and drop consists of the Doorstop container as leak tested and transported. Three drop orientations are evaluated.

\subsubsection{Containment Calculations}

The drop is performed in three orientations for the $9-m(30-f t)$ drop (enveloping case). An evaluation was performed to develop this worst-case g-loading from the actual N-55 crush observed after the drop tests of the Sample Pig Transport System (Part B, Section 7.6.1.4). As demonstrated by the evaluation, the Doorstop container will maintain containment after the 9-m $(30-\mathrm{ft})$ drop based on meeting ASME BPVC, Section VIII allowables. The Doorstop container leak rate is measured to be less than $1 \times 10^{-7}$ atm-cc/s, air, well below the $5.81 \times 10^{-5} \mathrm{std}-\mathrm{cc} / \mathrm{s}$ required.

\subsection{ACCIDENT CONDITIONS}

\subsubsection{Conditions To Be Evaluated}

The accident condition evaluation reviews hot and cold environmental conditions, pressurization, and the effects to the Doorstop Sample Carrier System containment boundary from the $9-m(30-f t)$ drop onto an unyielding surface.

\subsubsection{Containment Acceptance Criteria}

The allowable leak rate for accident conditions based on the contents is $1.04 \times 10^{-1} \mathrm{cc} / \mathrm{s}$, air (see Part B, Section 4.7). As the more restrictive NCT leak rate is met, the accident leak rate at standard conditions was not calculated.

\subsubsection{Containment Model}

The containment model used for the analysis consists of the Doorstop container as leak tested and transported. This packaging was compared to the Sample Pig Transport System, which was dropped $9 \mathrm{~m}(30 \mathrm{ft})$ in three orientations (side, end, and center of gravity-over-corner) onto a hard, unyielding surface (WHC 1995). The results of the Sample Pig Transport System testing were used to develop the forces used to evaluate the Doorstop container's ability to pass this test. 


$$
\text { HNF-SD-TP-SARP-023 Rev. } 0
$$

\subsubsection{Containment Calculations}

The Sample Pig Transport System drop was performed in three orientations for the 9-m (30-ft) drop (WHC 1995). Based on the results of the testing, the forces were calculated that the Doorstop container would experience if subjected to the same testing. The Doorstop container was evaluated (Part B, Section 7.6.1.4) to determine the stresses imposed by a $190 \mathrm{~g}$ deceleration loading. The worst-case deceleration is $188 \mathrm{~g}^{\prime} \mathrm{s}$ during the side drop. Stresses due to internal pressure are added to this evaluation for a combined stress case.

As demonstrated by evaluation, the Doorstop Container will maintain containment after the 9-m (30-ft) drop. The leak rate maintained is $1 \times 10^{-7} \mathrm{~atm}-\mathrm{cc} / \mathrm{s}$, air, as measured, well below the acceptance criteria of $1.04 \times 10^{-1} \mathrm{std}-\mathrm{cc} / \mathrm{s}$.

\subsection{CONTAINMENT EVALUATIONS AND CONCLUSIONS}

The Doorstop container has been shown by $9-\mathrm{m}(30-\mathrm{ft})$ drop analysis and closure vibration analysis to maintain containment during normal and accident conditions (Part B, Section 7.0).

An $\mathrm{N}-55$ overpack loaded with a Pig Shipping Container was drop tested $9 \mathrm{~m}$ (30 ft) onto an unyielding surface. Since the Doorstop containers are also inside the $\mathrm{N}-55$ overpack, a comparison of the two containers was performed to determine the effects of the drop on the Doorstop Sample Carrier System (Part B, Section 7.6.1.4). This g-loading was then used to analyze the closure lid of the Doorstop containers. Positive margins of safety in reference to ASME BPVC, Section VIII (ASME 1995), shear and tension allowables demonstrate that the closure lids will maintain containment during the 9-m $(30-\mathrm{ft}$ ) $\mathrm{ft}$ drop. Normal vibration loads per ANSI N14.23 (ANSI 1992) also were evaluated, and positive margins of safety against fatigue, peak shock, and shear demonstrate containment is also maintained through vibration loadings normally incident to transport.

\subsubsection{Environmental Conditions}

The Doorstop container closure lid (containment vessel) consists of an 8-in. stainless steel pipe flange with a Parker 45-durometer Neoprene 0-ring. The Neoprene material temperature range is $-54^{\circ} \mathrm{C}\left(-65^{\circ} \mathrm{F}\right)$ to $149^{\circ} \mathrm{C}\left(300{ }^{\circ} \mathrm{F}\right)$. The stainless steel material easily meets the requirements of $-40^{\circ} \mathrm{C}\left(-40{ }^{\circ} \mathrm{F}\right)$ to $37.77{ }^{\circ} \mathrm{C}\left(100{ }^{\circ} \mathrm{F}\right)$ and the Hanford Site conditions $-32.77{ }^{\circ} \mathrm{C}\left(-27{ }^{\circ} \mathrm{F}\right)$ to $46.11{ }^{\circ} \mathrm{C}\left(115^{\circ} \mathrm{F}\right)$.

\subsection{REFERENCES}

10 CFR 71, 1995, "Packaging and Transportation of Radioactive Material," Code of Federal Regulations, as amended.

49 CFR 173, 1995, "Shippers--General Requirements for Shipments and Packagings," Code of Federal Regulations, as amended. 
ANSI, 1992, Draft American National Standard Design Basis for Resistance to Shock and Vibration of Radioactive Material Packages Greater Than One Ton in Truck Transport, ANSI N14.23, American National Standards Institute, New York, New York.

ANSI, 1987, American National Standard for Radioactive Materials - Leakage Tests on Packages for Shipment, ANSI N14.5, American National Standards Institute, Inc., New York, New York.

ASME, 1995, ASME Boiler and Pressure Vessel Code, Section VIII, Division 2, American Society of Mechanical Engineers, New York, New York.

NRC, 1984, Information Notice No. 84-72, Clarification of Conditions for Waste Shipments Subject to Hydrogen Gas Generation, U.S. Nuclear Regulatory Commission, Washington, D.C. 


\subsection{APPENDIX: CONTAINMENT ANALYSES}

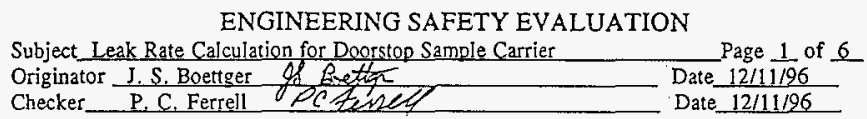

I. Objectives:

The purpose of this analysis is to determine the maximum allowable leak rates for the Doorstop Container during both Normal Conditions of Transport (NCT) and Hypothetical Accident Conditions (HAC). This leak rate will be compared to the leakrate criterion set in the Doorstop SARP to determine if the criterion is acceptable.

II. References:

ANSI N14.5, 1987, American National Standard for Radioactive Materials - Leakage Test on Packages for Shipment, American National Standards Institute, New York, New York.

Chemical Rubber Publishing Company, 1961, Handbook of Chemistry ond Physics, The Chemical Rubber Publishing Company, Cleveland, Ohio.

WHC, 1993, Safery Analysis Repor for Packaging, Doorstop Sample Carrier System, WHCSD-MP-SARP-DOl, Westinghouse Hanford Company, Richland, Washington.

MT. Results and Conclusions:

The maximum allowable leakrate, $L_{R}$, is $5.81 \times 10^{.5} \mathrm{std}-\mathrm{cc} / \mathrm{s}$. The containment criterion in the Doorstop SARP states that the Doorstop will be leaktight (less than $10^{-2} \mathrm{std}-\mathrm{cc} / \mathrm{s}$ ). Since this leaktight criterion is more restrictive than the maximum allowable leakrate, the leaktight criterion is acceptable.

\section{Engineering Evaluation:}

The method used for calculating leak rates will follow ANSI N14.5 guidelines. The method involves first determining the maximum allowable release rates, in $\mathrm{Ci} / \mathrm{sec}$, using the worst case source term information given in Table 1. The release rates are converted to leak rates, in cc/sec, using the void volume of the Doorstop, and the release fraction of the source term.

The maximum allowable leak rates are calculated at the existing temperature and pressure within the Doorstop. These values are converted to STP conditions for comparison to the criterion in the SARP. 
ENGINEERING SAFETY EVALUATION

Subject Leak Rate Calculation for Doorstop Sample Carrier Originator J.S. Boettger \&R

Checker P. C. Ferrel

Page 2 of 6

Date $12 / 11 / 96$

Date $12 / 11 / 96$

Table 1. Solid Tank Waste Source Tems for the Doorstop.

\begin{tabular}{|c|c|c|c|c|c|c|c|c|}
\hline Nuel. & $\begin{array}{l}\text { Worst Case } \\
\text { Solids Act. } \\
\text { Conc." (Ci/L) }\end{array}$ & $A_{2}\left(C_{i}\right)^{*}$ & $\begin{array}{c}875 \mathrm{~mL} \\
(30 \mathrm{oz}) \\
\mathrm{M} \Delta x . \text { Exp." } \\
(\mathrm{Bq})\end{array}$ & $\begin{array}{c}875 \mathrm{~mL} \\
(30 \mathrm{oz}) \\
\text { Max. Exp." } \\
\text { (Ci) }\end{array}$ & $A_{2} 3$ & $\begin{array}{c}875 \mathrm{~mL} \\
\langle 30 \mathrm{oz}\rangle \\
\text { Worst Cusec } \\
(\mathrm{Bq})\end{array}$ & $\begin{array}{c}875 \mathrm{~mL} \\
(30 \mathrm{oz}) \\
\text { Worst Cese } \\
\text { (Ci) }\end{array}$ & $A_{2} S$ \\
\hline${ }^{14} \mathrm{C}$ & $4.3 \mathrm{E}-06$ & $5.4 \mathrm{E}+01$ & $6.7 E+03$ & $1.8 \mathrm{E}-07$ & $3.3 E-09$ & $1.4 \mathrm{E}+05$ & $3.8 \mathrm{E}-06$ & 7.0E-08 \\
\hline${ }^{\infty} \mathrm{Co}$ & $1.3 \mathrm{E}-02$ & $1.1 E+01$ & $2.0 \mathrm{E}+07$ & $5.3 \mathrm{E}-04$ & $4.9 \mathrm{E}-05$ & 4. $1 \mathrm{E}+08$ & $1.1 E-02$ & $1.0 \mathrm{E}-03$ \\
\hline "Se & $4.6 \mathrm{E} \cdot 07$ & $5.4 \mathrm{E}+\mathrm{Ol}$ & $7.0 E+02$ & $1.9 \mathrm{E}-08$ & $3.5 E-10$ & $1.5 \mathrm{E}+04$ & 4.0E-07 & $7.4 \mathrm{E} \cdot 09$ \\
\hline${ }^{\infty} \mathrm{Sr}$ & $7.8 \mathrm{E}+01$ & $2.7 E+\infty$ & $1.2 E+11$ & $3.2 E+\infty$ & $1.2 E+\infty$ & $2.5 E+12$ & $6.8 \mathrm{E}+01$ & $2.5 \mathrm{E}+0 \mathrm{I}$ \\
\hline${ }^{\infty} \mathrm{Y}^{\prime}$ & $7.8 \mathrm{E}+01$ & $5.4 E+\infty$ & $1.2 E+11$ & $3.2 \mathrm{E}+\infty$ & 0.0 & $2.5 \mathrm{E}+12$ & $6.8 E+01$ & 0.0 \\
\hline${ }^{\circ} \mathrm{Ts}$ & $3.2 \mathrm{E}-0 \mathrm{I}$ & $2.4 \mathrm{E}+01$ & $4.8 \mathrm{E}+03$ & $1.3 \mathrm{E} \cdot 02$ & $5.4 E-0.4$ & $1.0 \mathrm{E}+10$ & $2.8 \mathrm{E}-01$ & $1.2 \mathrm{E}-02$ \\
\hline$N_{R: 1}$ & $1.9 E-06$ & $5.4 E+\infty$ & $2.9 E+03$ & $7.8 \mathrm{E}-08$ & 1.4E-08 & $6.3 \mathrm{E}+\mathrm{CQ}$ & $1.7 \mathrm{E} \cdot 06$ & 3.1E-07 \\
\hline${ }^{\infty} \mathrm{Rh}^{\mathrm{s}}$ & $1.9 E-06$ & 0.0 & $2.9 \mathrm{E} \div 03$ & $7.8 \mathrm{E}-03$ & 0.0 & $6.3 \mathrm{E}+04$ & $1.7 \mathrm{E}-06$ & 0.0 \\
\hline $1 \pm s b$ & $4.9 \mathrm{E}-03$ & $2.4 E+01$ & $7.4 E+\infty$ & $2.0 \mathrm{E}-04$ & 8.2E-06 & $1.6 E+08$ & 4.3E-03 & 1.8E-04 \\
\hline $1=9$ & 1.7E-0.4 & UNLIMITED & 2.6E+05 & $7.0 \mathrm{E} \cdot 06$ & 0.0 & $5.6 \mathrm{E}+\infty 6$ & $1.5 \mathrm{E} \cdot 04$ & 0.0 \\
\hline${ }^{12} \mathrm{Cs}$ & 2.5E-0.4 & $1.4 \mathrm{E}+01$ & $3.7 E+0.5$ & $1.0 E-05$ & $7.4 E-07$ & $8.1 \mathrm{E}+\infty 6$ & $2.2 \mathrm{E}-04$ & $1.6 \mathrm{E}-05$ \\
\hline${ }^{137} \mathrm{Cs}$ & $2.7 E+\infty$ & $1.4 E+01$ & 4.1E+09 & 1.1E.01 & $8.2 E-03$ & $8.9 E+10$ & $2.4 \mathrm{E}+\infty$ & $1.8 \mathrm{E}-01$ \\
\hline${ }^{137 m} \mathrm{Ba}^{6}$ & $2.6 \mathrm{E}+\infty$ & 0.0 & $4.1 E+\infty$ & $1.1 \mathrm{E}-01$ & 0.0 & $8.5 E+10$ & $2.3 \mathrm{E}+\infty$ & 0.0 \\
\hline${ }^{34} \mathrm{Ce}$ & $9.2 \mathrm{E}-09$ & $5.4 \mathrm{E}+\infty$ & $1.4 E+01$ & $3.8 \mathrm{E}-10$ & $7.0 \mathrm{E}-11$ & $3.0 \mathrm{E}+02$ & $8.1 \mathrm{E}-09$ & $1.5 \mathrm{E}-09$ \\
\hline${ }^{1+\infty} \mathrm{PT}^{1}$ & $9.2 E-09$ & 0.0 & $1.4 \mathrm{E} \div \mathrm{OL}$ & $3.8 E-10$ & 0.0 & $3.0 E+02$ & 8.1E-09 & 0.0 \\
\hline${ }^{ \pm s} \mathrm{Eu}$ & $3.0 \mathrm{E}-01$ & $1.4 \mathrm{E} \div 0 \mathrm{~L}$ & $4,4 E+08$ & $1.2 \mathrm{E}-02$ & $8.9 \mathrm{E}-04$ & $9.6 \mathrm{E}+09$ & $2.6 \mathrm{E}-01$ & $1.9 \mathrm{E}-02$ \\
\hline $1, s_{\mathrm{Eu}}$ & 1.4E-04 & $5.4 \mathrm{E}+01$ & $2.1 E+05$ & $5.7 E-06$ & 1.1E-07 & 4.4E+06 & 1.2E-04 & $2.2 \mathrm{E}-06$ \\
\hline${ }^{3} N_{p}$ & $2.7 \mathrm{E} \cdot \mathrm{C2}$ & $5.4 \mathrm{E}-03$ & 4. $1 \mathrm{E}+07$ & $1.1 \mathrm{E}-03$ & $2.0 \mathrm{E}-01$ & $8.9 \mathrm{E}+08$ & $2.4 \mathrm{E}-02$ & $4.4 E+\infty$ \\
\hline${ }^{328} \mathrm{Pu}$ & S.1E-03 & $5.4 E-03$ & $7.8 E+\infty 6$ & $2,1 \mathrm{E} \cdot 0.04$ & $3.9 \mathrm{E} \cdot 02$ & $1.7 \mathrm{E}+08$ & 4.5E-03 & 8.3E-01 \\
\hline${ }^{399} P_{1}$ & $4.3 \mathrm{E}-02$ & $5.4 \mathrm{E}-03$ & $6.7 \mathrm{E}+07$ & $1.8 \mathrm{E}-03$ & $3.3 E-01$ & 1. $4 E+\infty$ & $3.8 \mathrm{E}-02$ & $7.0 E+\infty$ \\
\hline$=\infty_{p u^{4}}$ & 4.3E-0? & $5.4 \mathrm{E}-03$ & $6.7 \mathrm{E} \div 07$ & $1.8 \mathrm{E}-03$ & $3.3 \mathrm{E}-01$ & $1.4 \mathrm{E}+09$ & $3.8 \mathrm{E}-02$ & $7.0 \mathrm{E}+00$ \\
\hline${ }^{241} \mathrm{Pu}$ & $1.0 \mathrm{E}-01$ & $2.7 \mathrm{E}-01$ & $1.5 \mathrm{E} \div 08$ & $4.1 E-03$ & 1.SE-02 & $3.3 \mathrm{E}+09$ & $8,8 \mathrm{E}-02$ & $3.3 \mathrm{E}-01$ \\
\hline$: \mathrm{Am}$ & 3.OE-01 & $5.4 \mathrm{E}-03$ & $4.4 E+08$ & $1.2 E-02$ & $2.2 E+\infty$ & $9.6 \mathrm{E}+09$ & $2.6 \mathrm{E}-01$ & $4.8 \mathrm{E}+01$ \\
\hline${ }^{202} \mathrm{Cm}$ & $5.4 \mathrm{E}-0$ & 2.7E-01 & $8.1 E+\infty$ & $2.2 \mathrm{E} \cdot 10$ & $8.2 \mathrm{E} \cdot 10$ & 1.7E+02 & $4.7 \mathrm{E}-09$ & $1.7 \mathrm{E} .08$ \\
\hline${ }^{24} \mathrm{Cm}$ & $1.6 \mathrm{E}-03$ & $1.1 \mathrm{E}-02$ & $2.4 \mathrm{E}+\infty$ & $6.6 \mathrm{E}-05$ & 6.JE-03 & $5.2 E+07$ & 1.4E-03 & $1.3 \mathrm{E}-0 \mathrm{t}$ \\
\hline TOTALS & $1.6 \mathrm{E}+02$ & & $2.5 E+11$ & $6.7 E+\infty$ & $4.3 E+\infty$ & $5.3 E+12$ & $1.4 \mathrm{E}+02$ & $9.3 E+01$ \\
\hline
\end{tabular}


ENGINEERING SAFETY EVALUATION

Subject Leak Rate Calculation for Doorstop Sample Carrier Originator J.S. Bnettger QKT

Page 3 of $\underline{6}$

Checker P. C. Ferrell PCt

Date $12 / 11 / 96$

Date $12 / 11 / 96$

' $\mathrm{A}_{2}$ values taken Irom 49 CFR 173.435, 1995, "Shippers-General Requirements for Shipments and Packegings," Code of Federal Regulations, as amerided.

'Maximum expecled source lerm derived using the solid tark weste activity concentrations ( $\mathrm{Ci} / \mathrm{L}$ ) and

multiplying by the factor 0.041 such that the total Doorstop radioastive losding results in a dose rate less than $2 \mathrm{mSv} / \mathrm{h}$ (200 mren/h) at the package surface.

Worst-case source term assumes $875 \mathrm{~mL}$ ( $30 \mathrm{oz}$ ) of solid tarik werte.

Q40 PJ conservatively set equal to $20 \%$ ps.

'Values taken from WHC-SD-WM-SARR.016, Rev. 2 (WHIC 1996). Daughters calculated ORJGEN2.

'This radionuclide is a daughter as defined in 49 CFR 173.433, therefore, its activity was set to 0 for the A2 celculations. 


\section{ENGINEERING SAFETY EVALUATION}

Subject Leak Rate Calculation for Doorstop Sample Carrier

Originator J. S. Boettger $\$ \mathrm{Q}$

Page 4 of 6

Checker P.C. Fertell PCt

Date $12 / 11 / 96$

Date $12 / 11 / 96$

\section{Release Rates}

The total number of $A_{2} s$ for the mixture is $93 A_{2} s$, as shown in Table 1 , making it a Type $B$ package. The allowable release rates for NCT and HAC are given in 10 CFR $\$ 71.51$, Additional requirements for Type B packages, and are given below. Also, the total number of curies is $140 \mathrm{Ci}$, so the $\mathrm{A}_{2}$ for the mixture is $140 \mathrm{Ci} / 93=1.51 \mathrm{Ci}$.

Release rate for NCT, $R_{k}$, $=1 \times 10^{-6} \mathrm{~A}_{2} / \mathrm{hr}=2.778 \times 10^{-10} \mathrm{~A}_{2} / \mathrm{sec}$

Release rate for $\mathrm{HAC}, \mathrm{R}_{\mathrm{A}}, \doteq 1 \mathrm{~A}_{2} /$ week $=1.653 \times 10^{-6} \mathrm{~A}_{2} / \mathrm{sec}$

$R_{N}=\left(2.778 \times 10^{-19}\right)(1.51 \mathrm{Ci})=4.19 \times 10^{-10} \mathrm{Ci} / \mathrm{sec}$

$R_{A}=\left(1.653 \times 10^{-6}\right)(1.51 \mathrm{Ci})=2.50 \times 10^{-6} \mathrm{Ci} / \mathrm{sec}$

\section{Activity Concentration}

For NCT and HAC, a fraction of the solid material is assumed to exist as suspended particles in the void volume. ANSI N14.5, Example B16.31, suggests a maximum particle density of $9.0 \times 10^{-6} \mathrm{~g} / \mathrm{cc}$. The total grams in the source term is calculated to be $52.5 \mathrm{~g}$, as shown in the Appendix.

$$
C_{X}=C_{A}=\left(9.0 \times 10^{-5} \mathrm{~g} / \mathrm{cc}\right)(140 \mathrm{Ci}) /(52.5 \mathrm{~g})=2.4 \times 10^{-5} \mathrm{Ci} / \mathrm{cc}
$$




\section{ENGINEERING SAFETY EVALUATION}

Subject Leak Rate Calculation for Doorstop Sample Carrier

Originator J.S. Boettger OPI. Date 12/11/96.

Checker P. C. Ferrell PCF Date 12/11/96

\section{Allowable Leck Rates}

For $\left.N C T, L_{N}=R_{N} / C_{N}=4.19 \times 10^{-10} \mathrm{Ci} / \mathrm{sec}\right) /\left(2.4 \times 10^{-5} \mathrm{Ci} / \mathrm{cc}\right)=1.75 \times 10^{-5} \mathrm{cc} / \mathrm{sec}$.

For $\left.\mathrm{HAC}, \mathrm{L}_{\mathrm{A}}=\mathrm{R}_{\mathrm{A}} / \mathrm{C}_{\mathrm{A}}=2.50 \times 10^{-6} \mathrm{Ci} / \mathrm{sec}\right) /\left(2.4 \times 10^{-3} \mathrm{Ci} / \mathrm{cc}\right)=1.04 \times 10^{-1} \mathrm{cc} / \mathrm{sec}$.

The bounding case is the more restrictive $\mathrm{L}_{\mathrm{N}}$. The conditions for $\mathrm{NCT}$ are a temperature of $173^{\circ} \mathrm{F}(351 \mathrm{~K})$ and a pressure of $5 \mathrm{psig}(1.34 \mathrm{~atm})$. To find, $\mathrm{L}_{n}$, the leakage rate at standard conditions, the flow conditions must first be evaluated.

The critical pressure ratio for air is 0.528 . For NCT, the pressure ratio, Pd/Pu, using 1.0 $\mathrm{atm}$ as the downstream pressure, is $1.0 \mathrm{~atm} / 1.34 \mathrm{~atm}=0.746$. So, the flow is unchoked and $L_{R}$ is found using Equation B15 from ANSI N14.5.

$$
L_{R}=L_{N}\left(\frac{\mu_{N}}{\mu_{R}}\right) \frac{\left(P_{u}-P_{d}\right)_{R}}{\left(P_{u}-P_{d}\right)_{N}} \mathrm{~cm}^{3} / \mathrm{s}
$$

where:

$L_{R}=$ Leakage rate at STP $\left(s t d \mathrm{~cm}^{3} / \mathrm{s}\right)$

$\mathrm{I}_{\mathrm{N}}=$ Leakage rate at NCT conditions

$\mu_{\mathrm{R}}=$ fluid viscosity at STP (air)

$\mu_{N}=$ fluid viscosity at NCT conditions (air)

$=1.75 \times 10^{-5} \mathrm{~cm}^{3} / \mathrm{s}$

$\left(P_{\mathrm{u}}-\mathrm{P}_{\mathrm{d}}\right)_{\mathrm{R}}=$ pressure differential at STP

$=0.0185 \mathrm{cP}$ (ANSI N14.5, Table BI)

$\left(P_{u}-P_{J}\right)_{N}=$ pressure differential at $N C T$

$=0.0211 \mathrm{cP}$ (Chemical Handbook)

$=0.99 \mathrm{~atm}(1.00 \mathrm{~atm}-0.01 \mathrm{~atm})$

$=0.34 \mathrm{~atm}(1.34 \mathrm{~atm}-1.00 \mathrm{~atm})$

Solving for $\mathrm{L}_{R}$ gives $5.81 \times 10^{-5} \mathrm{std} \mathrm{cm}^{3} / \mathrm{s}$

This is the maximum allowable leak rate to remain within the requirenents of 10CFR \$71.51. 


\section{ENGINEERING SAFETY EVALUATION}

Subject Leak Rate Calculation for Doorstop Sample Carrier Originator J.S. Boettger OAP

Checker

\section{Appendix}

Mass of Source Term

\begin{tabular}{|c|c|c|c|c|c|c|c|}
\hline & Activity & Spec.Activity & Quantity & & Activity & Spec Activity & Quantity \\
\hline Nuclide & $\mathrm{Ci}$ & $\mathrm{Ci} / \mathrm{g}$ & $\mathrm{g}$ & Nuclide & $\mathrm{Ci}$ & $\mathrm{Ci} / \mathrm{g}$ & $\mathrm{g}$ \\
\hline C-14 & $3.80 e-06$ & $4.50 e+00$ & $8.44 e-07$ & Ce-144 & $8.10 e-09$ & $3.20 \mathrm{e}+03$ & $2.53 e-12$ \\
\hline $\mathrm{CO}-60$ & 1. $10 e-02$ & $1.10 e+03$ & $1.00 \mathrm{e}-05$ & $\operatorname{Pr}-144$ & $8.10 \mathrm{e}-09$ & $7.60 \mathrm{e}+07$ & $1.07 \mathrm{e}-16$ \\
\hline $\mathrm{Se}-79$ & $4.00 \mathrm{e}-07$ & $7.00 \mathrm{e}-02$ & $5.71 \mathrm{e}-06$ & Eu-154 & $2.60 \mathrm{e}-01$ & $2.60 \mathrm{e}+02$ & $1.00 e-03$ \\
\hline $\mathrm{Sr}-90$ & $6.80 e+01$ & $1.40 \mathrm{e}+02$ & $4.86 e-01$ & Eu-155 & $1.20 \mathrm{e}-04$ & $4.90 \mathrm{e}+03$ & $2.45 \mathrm{e}-08$ \\
\hline$Y-90$ & $6.80 e+01$ & $5.40 e+05$ & $1.26 \mathrm{e}-04$ & $\mathrm{~Np}-237$ & $2.40 \mathrm{e}-02$ & $7.10 \mathrm{e}-04$ & $3.38 \mathrm{e}+01$ \\
\hline Tc-99 & $2.80 \mathrm{e}-01$ & $1.70 \mathrm{e}-02$ & $1.65 \mathrm{e}+01$ & Pu-238 & $4.50 \mathrm{e}-03$ & $1.70 e+01$ & $2.65 e-04$ \\
\hline Ru-106 & $1.70 \mathrm{e}-06$ & $3.30 \mathrm{e}+03$ & $5.15 \mathrm{e}-10$ & Pu-239 & $3.80 e-02$ & $6.20 \mathrm{e}-02$ & $6.13 e-01$ \\
\hline $\mathrm{Rh}-106$ & $1.70 \mathrm{e}-06$ & $3.50 \mathrm{e}+09$ & $4.86 \mathrm{e}-16$ & $\mathrm{Pu}-240$ & $3.80 \mathrm{e}-02$ & $2.30 e-01$ & $1.65 \mathrm{e}-01$ \\
\hline$S b-125$ & $4.30 \mathrm{e}-03$ & $1.00 \mathrm{e}+03$ & $4.30 \mathrm{e}-06$ & Pu-241 & $8.80 \mathrm{e}-02$ & $1.00 e+02$ & $8.80 \mathrm{e}-04$ \\
\hline $\mathrm{I}-129$ & $1.50 \mathrm{e}-04$ & $1.80 \mathrm{e}-04$ & $8.33 e-01$ & Am-241 & $2.60 \mathrm{e}-01$ & $3.40 e+00$ & $7.65 \mathrm{e}-02$ \\
\hline $\mathrm{Cs}-134$ & $2.20 \mathrm{e}-04$ & $1.30 \mathrm{e}+03$ & $1.69 \mathrm{e}-07$ & $\mathrm{Cm}-242$ & $4.70 \mathrm{e}-09$ & $3.30 \mathrm{e}+03$ & $1.42 \mathrm{e}-12$ \\
\hline $\mathrm{Cs}-137$ & $2.40 \mathrm{e}+\infty 0$ & $8.70 e+01$ & $2.76 e-02$ & $\mathrm{Cm}-244$ & $1.40 \mathrm{e}-03$ & $8.10 e+05$ & $1.73 e-09$ \\
\hline \multirow[t]{2}{*}{$\mathrm{Ba}-137 \mathrm{~m}$} & $2.30 \mathrm{e}+00$ & $5.40 \mathrm{e}+08$ & $4.26 \mathrm{e}-09$ & & & & \\
\hline & & & & Totals & $1.42 \mathrm{e}+02$ & …- & $5.25 e+01$ \\
\hline
\end{tabular}


HNF-SD-TP-SARP-023 Rev. 0

\subsection{SHIELDING EVALUATION}

\subsection{INTRODUCTION}

This shielding evaluation supports the shipment of tank waste samples in the Doorstop Sample Carrier System. The Doorstop Sample Carrier System will transport liquid and solid samples from the Hanford Site underground storage tanks. A 125-mL sample is placed inside a "paint can," which is then placed inside the Doorstop container. A maximum of seven Doorstops are placed inside a DOT 208-L drum, which is then loaded into an $\mathrm{N}-55$ overpack. There are several other loading configurations for the Doorstop Sample Carrier System. However, the other configurations have a smaller radioactive inventory and in some cases additional shielding. Therefore, the shielding analysis results for the configuration that includes seven $125-\mathrm{mL}$ samples will bound the results for these other configurations.

Transportation safety typically requires a dose rate of less than $2 \mathrm{mSv} / \mathrm{h}$ $(200 \mathrm{mrem} / \mathrm{h})$ on the surface of the overpack, less than $2 \mathrm{mSv} / \mathrm{h}(200 \mathrm{mrem} / \mathrm{h})$ at the vehicle surface, and less than $0.1 \mathrm{mSv} / \mathrm{h}(10 \mathrm{mrem} / \mathrm{h})$ at $2 \mathrm{~m}$ from the surface. There is an additional limit of $0.05 \mathrm{mSv} / \mathrm{h}(5 \mathrm{mrem} / \mathrm{h})$ in any normally occupied space (i.e., at the location of the truck driver) if the driver is a qualified Hanford Site radiological worker. If the driver is not a qualified radiological worker, the allowable dose rate is reduced to $0.02 \mathrm{mSv} / \mathrm{h}(2 \mathrm{mrem} / \mathrm{h})$. If the dose rates are exceeded, the administrative controls outlined in Part A, Section 6.0, will be followed.

\subsection{DIRECT RADIATION SOURCE SPECIFICATION}

\subsubsection{Gamma Source}

The activity concentrations used to derive the gamma source term were taken from Part B, Section 2.0, and are listed in Table B5-1. The Doorstop Sample Carrier system will contain both solid and liquid tank waste. The shielding analysis will be done using the worst-case solid tank waste radionuclide composition (see Table $\mathrm{B} 5-1$ ) since the dose rates from solid tank waste bounds those from liquid waste. Two different cases will be analyzed as described below.

Historically, the dose rates on the surface of the N-55 overpack have been less than $2 \mathrm{mSv} / \mathrm{h}(200 \mathrm{mrem} / \mathrm{h})$. The first configuration analyzed is for a radioactive inventory that results in a $2-\mathrm{mSv} / \mathrm{h}(200-\mathrm{mrem} / \mathrm{h})$ surface dose rate when seven $125-\mathrm{mL}$ samples $(875 \mathrm{~mL}$ total) are loaded into the $\mathrm{N}-55$. This source term, called the maximum expected source term, was derived using the worst-case solid tank waste activity concentrations (Table B5-1) and reducing the total activity of each radionuclide to yield a surface dose rate of $2 \mathrm{mSv} / \mathrm{h}(200 \mathrm{mrem} / \mathrm{h})$. A scaling factor of 0.047 was applied to the activity concentrations ( $\mathrm{C} / \mathrm{L}$ ) from Table B5-1 to produce $2 \mathrm{mSv} / \mathrm{h}(200 \mathrm{mrem} / \mathrm{h})$. The second case assumes that seven $125-\mathrm{mL}$ samples $(875 \mathrm{~mL}$ total) containing the worst-case solids source term from Table B5-1 are loaded in the $\mathrm{N}-55$. Both source terms are 1 isted in Table B5-1. 
Table B5-1. Solid Tank Waste Source Terms for the Doorstop Sample Carrier System.

\begin{tabular}{|c|c|c|c|c|c|}
\hline Nucl ide & $\begin{array}{l}\text { Worst-case } \\
\text { tank solids } \\
\text { activity } \\
\text { concentration } \\
\text { (Ci/L) }\end{array}$ & $\begin{array}{l}875 \mathrm{~mL} \text { of } \\
\text { maximumb } \\
\text { expected } \\
\text { (Ci) }\end{array}$ & $\begin{array}{c}875 \mathrm{~mL} \text { of } \\
\text { maximum } \\
\text { expected } \\
\text { (Bq) }\end{array}$ & $\begin{array}{c}875 \mathrm{~mL} \text { of } \\
\text { worst-case } \\
\text { tank solids } \\
\text { (Ci) }\end{array}$ & $\begin{array}{c}875 \mathrm{~mL} \text { of } \\
\text { worst-case } \\
\text { tank solids } \\
\text { (Bq) }\end{array}$ \\
\hline${ }^{14} \mathrm{C}$ & 4.3 E- 06 & 2.0 E-07 & $7.4 E+03$ & $3.8 E-06$ & $1.4 E+05$ \\
\hline${ }^{60} \mathrm{Co}$ & $1.3 \mathbf{E}-02$ & $6.1 E-04$ & $2.3 \mathrm{E}+07$ & $1.1 \mathrm{E}-02$ & $4.2 E+08$ \\
\hline${ }^{79} \mathrm{Se}$ & $4.6 \mathrm{E}-07$ & 2.2 E- 08 & $8.1 E+02$ & 4.0 E-07 & $1.5 \varepsilon+04$ \\
\hline${ }^{90} \mathrm{sr}$ & $7.8 \mathrm{E}+01$ & $3.7 E+00$ & $1.4 \mathrm{E}+11$ & $6.8 \mathrm{E}+01$ & $2.5 E+12$ \\
\hline${ }^{90} \mathrm{Y}$ & $7.8 \mathrm{E}+01$ & $3.7 E+00$ & $1.4 \mathrm{E}+11$ & $6.8 E+01$ & $2.5 E+12$ \\
\hline${ }^{99} \mathrm{Tc}$ & 3.2 E-01 & $1.5 \mathrm{E}-02$ & $5.6 E+08$ & $2.8 \mathrm{E}-01$ & $1.0 \mathrm{E}+10$ \\
\hline${ }^{106} \mathrm{Ru}$ & $1.9 \mathrm{E}-06$ & 8.9 E-08 & $3.3 E+03$ & $1.7 E-06$ & $6.2 E+04$ \\
\hline $106_{\mathrm{Rh}}$ & 1.9 E-06 & $8.9 E-08$ & $3.3 E+03$ & $1.7 \mathrm{E}-06$ & $6.2 E+04$ \\
\hline${ }^{125} \mathrm{Sb}$ & $4.9 \mathrm{E}-03$ & $2.3 E-04$ & $8.5 \mathrm{E}+06$ & $4.3 \mathrm{E}-03$ & $1.6 \mathrm{E}+08$ \\
\hline $129_{1}$ & $1.7 \mathrm{E}-04$ & $8.0 \mathrm{E}-06$ & $3.0 \mathrm{E}+05$ & $1.5 \mathrm{E}-04$ & $5.5 E+06$ \\
\hline${ }^{134} \mathrm{cs}$ & 2.5 E- 04 & $1.2 \mathrm{E}-05$ & $4.4 E+05$ & 2.2 E- 04 & $8.1 E+06$ \\
\hline${ }^{137} \mathrm{Cs}$ & $2.7 \mathrm{E}+00$ & $1.3 \mathrm{E}-01$ & $4.8 \mathrm{E}+09$ & $2.4 \mathrm{E}+00$ & $8.7 E+10$ \\
\hline $137 \mathrm{~m}_{\mathrm{Ba}}$ & $2.6 \mathrm{E}+00$ & $1.2 \mathrm{E}-01$ & $4.4 E+09$ & $2.3 \mathrm{E}+00$ & $8.4 E+10$ \\
\hline${ }^{144} \mathrm{Ce}$ & 9.2 E-09 & $4.3 \mathrm{E}-10$ & $1.6 E+01$ & $8.1 E-09$ & $3.0 \mathrm{E}+02$ \\
\hline${ }^{144} \mathrm{Pr}$ & 9.2 E- 09 & $4.3 E-10$ & $1.6 \mathrm{E}+01$ & $8.1 E-09$ & $3.0 \mathrm{E}+02$ \\
\hline${ }^{154} \mathrm{Eu}$ & $3.0 \mathrm{E}-01$ & $1.4 \mathrm{E}-02$ & $5.2 \mathrm{E}+08$ & 2.6 E-01 & $9.7 E+09$ \\
\hline${ }^{155} \mathrm{Eu}$ & $1.4 \mathrm{E}-04$ & $6.6 \mathrm{E}-06$ & $2.4 E+05$ & $1.2 \mathrm{E}-04$ & $4.5 \mathrm{E}+06$ \\
\hline $237_{\mathrm{Np}}$ & $2.7 E-02$ & $1.3 \mathrm{E}-03$ & $4.8 \mathrm{E}+07$ & 2.4 E- 02 & $8.7 \mathrm{E}+08$ \\
\hline${ }^{238} \mathrm{Pu}$ & $5.1 E-03$ & $2.4 \mathrm{E}-04$ & $8.9 \mathrm{E}+06$ & $4.5 \mathrm{E}-03$ & $1.7 E+08$ \\
\hline${ }^{239} \mathrm{Pu}$ & $4.3 \mathrm{E}-02$ & $2.0 \mathrm{E}-03$ & $7.4 E+07$ & $3.8 \mathrm{E}-02$ & $1.4 E+09$ \\
\hline${ }^{240} \mathrm{Pu}^{\mathrm{c}}$ & 4.3 E- 02 & $2.0 \mathrm{E}-03$ & $7.4 E+07$ & $3.8 \mathrm{E}-02$ & $1.4 E+09$ \\
\hline${ }^{241} \mathrm{Pu}$ & $1.0 \mathrm{E}-01$ & $4.7 \mathrm{E}-03$ & $1.7 E+08$ & 8.8 E-02 & $3.2 E+09$ \\
\hline${ }^{241_{\mathrm{Am}}}$ & $3.0 \mathrm{E}-01$ & $1.4 \mathrm{E}-02$ & $5.2 \mathrm{E}+08$ & $2.6 \mathrm{E}-01$ & $9.7 E+09$ \\
\hline${ }^{242} \mathrm{~cm}$ & $5.4 \mathrm{E}-09$ & $2.5 E-10$ & $9.3 E+00$ & 4.7 E- 09 & $1.7 \mathrm{E}+02$ \\
\hline${ }^{244} \mathrm{Cm}$ & $1.6 \mathrm{E}-03$ & $7.5 \mathrm{E}-05$ & $2.8 E+06$ & $1.4 \mathrm{E}-03$ & $5.2 \mathrm{E}+07$ \\
\hline Totals & $1.6 E+02$ & $7.7 \mathrm{E}+00$ & $2.9 \mathrm{E}+11$ & $1.4 E+02$ & $5.3 E+12$ \\
\hline
\end{tabular}

Taken from WHC-SD-LM-SARR-016, Rev 2 (WHC 1996).

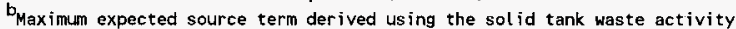
concentrations $(\mathrm{Ci} / \mathrm{L})$ and multiplying by the factor 0.047 such that the total radioactive loading $(875 \mathrm{~mL}=7$ Doorstops $x 125 \mathrm{~mL}$ ) results in a dose rate less than $200 \mathrm{mrem} / \mathrm{h}$ at the $\mathrm{N}-55$ overpack surface.

c240 $\mathrm{Pu}$ conservatively set equal to ${ }^{239} \mathrm{Pu}$.

WHC, 1996, Tank Waste Compositions and Atmospheric Dispersion Coefficients for Use in Safety Analys is Consequence Assessments, WHC-SD-WM-SARR-016, Rev. 2, Westinghouse Hanford Company, Richland, Washington. 


$$
\text { HNF-SD-TP-SARP-023 Rev. } 0
$$

The ORIGEN2 (Schmittroth 1994) computer code was used to calculate the gamma-ray source based on the radioactive loadings identified in Table B5-1. Table B5-2 lists the ORIGEN2 photon emission rates for each energy group. The ORIGEN2 was run using the photon library for bremsstrahiung in water.

Table B5-2. Photon Emission Rates (Photons/s) for the Doorstop Sample Carrier System.

\begin{tabular}{|c|c|c||c|c|c|}
\hline $\begin{array}{c}\text { Energy } \\
\text { (MeV) }\end{array}$ & $\begin{array}{c}875 \mathrm{~mL} \text { of } \\
\text { maximum expected } \\
\text { source term }\end{array}$ & $\begin{array}{c}875 \mathrm{~mL} \text { of } \\
\text { worst-case } \\
\text { tank solids }\end{array}$ & $\begin{array}{c}\text { Energy } \\
\text { (MeV) }\end{array}$ & $\begin{array}{c}875 \mathrm{~mL} \text { of } \\
\text { maximum expected } \\
\text { source term }\end{array}$ & $\begin{array}{c}875 \mathrm{~mL} \text { of } \\
\text { worst } \text { case } \\
\text { tank solids }\end{array}$ \\
\hline \hline 0.015 & $8.41 \mathrm{E}+09$ & $1.56 \mathrm{E}+11$ & 1.25 & $3.58 \mathrm{E}+08$ & $6.62 \mathrm{E}+09$ \\
\hline 0.025 & $1.78 \mathrm{E}+09$ & $3.29 \mathrm{E}+10$ & 1.75 & $1.27 \mathrm{E}+07$ & $2.35 \mathrm{E}+08$ \\
\hline 0.0375 & $1.59 \mathrm{E}+09$ & $2.94 \mathrm{E}+10$ & 2.25 & $1.32 \mathrm{E}+03$ & $2.43 \mathrm{E}+04$ \\
\hline 0.0575 & $1.92 \mathrm{E}+09$ & $3.56 \mathrm{E}+10$ & 2.75 & $3.83 \mathrm{E}+00$ & $7.09 \mathrm{E}+01$ \\
\hline 0.085 & $1.07 \mathrm{E}+09$ & $1.98 \mathrm{E}+10$ & 3.5 & $2.36 \mathrm{E}+00$ & $4.36 \mathrm{E}+01$ \\
\hline 0.125 & $9.21 \mathrm{E}+08$ & $1.70 \mathrm{E}+10$ & 5 & $9.58 \mathrm{E}-01$ & $1.77 \mathrm{E}+01$ \\
\hline 0.225 & $1.04 \mathrm{E}+09$ & $1.93 \mathrm{E}+10$ & 7 & $1.09 \mathrm{E}-01$ & $2.01 \mathrm{E}+00$ \\
\hline 0.375 & $4.85 \mathrm{E}+08$ & $8.98 \mathrm{E}+09$ & 11 & $1.24 \mathrm{E}-02$ & $2.29 \mathrm{E}-01$ \\
\hline $0.662 *$ & $5.07 \mathrm{E}+09$ & $9.38 \mathrm{E}+10$ & Total & $2.30 \mathrm{E}+10$ & $4.25 \mathrm{E}+11$ \\
\hline 0.85 & $3.46 \mathrm{E}+08$ & $6.40 \mathrm{E}+09$ & & &
\end{tabular}

of $137 \mathrm{~m}_{\mathrm{Ba}}^{*}$. Changed from $0.575 \mathrm{MeV}$ to $0.662 \mathrm{Mev}$ to accurately reflect the photon emitted during the decay
.

\subsubsection{Beta Source}

Beta particles originating in the source do not contribute to the dose rate outside the overpack because of the shielding provided by the shipping container. This shielding is described in Part B, Section 5.4.3. The bremsstrahlung radiation produced by the deceleration of the beta particles in the source is accounted for in the photon emission rates calculated using the ORIGEN2 (Schmittroth 1994) computer code.

\subsubsection{Neutron Source}

All the actinides listed in Table B5-1 will fission spontaneously. The total neutron source strength from spontaneous fission was computed to be $3.2 \times 10^{2}$ neutrons $/ \mathrm{s}$ for $875 \mathrm{~mL}$ of the worst-case solid tank waste. The ratio of the neutron dose to the gamma dose will be the same for both cases; $1 . e$. , $875 \mathrm{~mL}$ of the maximum expected and $875 \mathrm{~mL}$ of the worst-case source term. The neutron source term was calculated assuming that the source material was in oxide form. The concentration of fissile material is very low, so neutron multiplication will also be low (Part B, Section 6.0). The neutron dose rate was estimated using the methods described in Nelson (1996) and was found to be insignificant compared to the gamma dose rate. Therefore, the neutron dose rates are not reported. 
HNF-SD-TP-SARP-023 Rev. 0

\subsection{SUMMARY OF SHIELDING PROPERTIES OF MATERIALS}

The shielding consists mainly of the steel contained in the Doorstop Sample Carrier System. There is also a small amount shielding from the steel in the $55-g a l l o n$ drum and the outer shell of the $\mathrm{N}-55$ overpack. The Doorstops are surrounded by a polystyrene spacer, and the volume between the inner and outer shell of the $\mathrm{N}-55$ overpack is filled with polyurethane foam. However, these plastic materials provide little shielding because of their low density. The shielding attenuation properties for the bulk materials used in this analysis were obtained from the Monte Carlo N-Particle (MCNP) computer code data library (Breismeister 1993; Carter 1995). A description of the configuration and densities of the shielding materials used in the calculational models is given in Part B, Section 5.4.3.

\subsection{NORMAL CONDITIONS OF TRANSPORT}

\subsubsection{Conditions To Be Evaluated}

Dose rates will be evaluated at the overpack surface; at the vehicle surface, which in this case is the side or back of the truck; and at $2 \mathrm{~m}$ from the vehicle surface. Dose rates will also be calculated at $15 \mathrm{~cm}$ (6 in.) from the front end of the truck bed, which is the approximate distance to the nearest normally occupied space; i.e., the driver.

\subsubsection{Acceptance Criteria}

Transportation safety specifies a maximum of $2 \mathrm{mSv} / \mathrm{h}(200 \mathrm{mrem} / \mathrm{h})$ on any surface of the overpack, $2 \mathrm{mSv} / \mathrm{h}(200 \mathrm{mrem} / \mathrm{h})$ at the vehicle surface, $0.1 \mathrm{mSv} / \mathrm{h}(10 \mathrm{mrem} / \mathrm{h})$ at $2 \mathrm{~m}$ from the vehicle surface, and $0.05 \mathrm{mSv} / \mathrm{h}$ ( $5 \mathrm{mrem} / \mathrm{h}$ ) in any normally occupied space for radiological workers or $0.02 \mathrm{mSv} / \mathrm{h}$ (2 mrem/h) in any normally occupied space for nonradiological workers. If the limits are exceeded, the administrative controls outlined in Part A, Section 6.0, will be enforced.

\subsubsection{Shielding Model}

The MCNP computer code (Breismeister 1993; Carter 1995) was used for the gamma-ray dose rate calculations. MCNP is a three-dimensional Monte Carlo computer code and uses Evaluated Nuclear Data Files (ENDF/B) for cross sections (BNL 1991). The ENDF/B system is maintained by the National Nuclear Data Center at Brookhaven National Laboratory under contract from the U.S. Department of Energy. The quality assurance documentation of MCNP for use at the Hanford Site is given in Carter (1996). Bremsstrahlung photons are accounted for in the dose rate calculations. Fluence-to-dose conversion factors were conservatively based on an anterior-to-posterior irradiation pattern (ANSI/ANS 1991) and are listed in Table B5-3. 
HNF-SD-TP-SARP-023 Rev. 0

Table B5-3. Photon Fluence-to-dose Conversion Factors.*

\begin{tabular}{|c|c||c|c|}
\hline Energy (MeV) & $\begin{array}{c}\text { Flux-to-dose rate } \\
(m r e m / h) /(\text { photon/cm/s) }\end{array}$ & Energy (MeV) & $\begin{array}{c}\text { Flux-to-dose rats } \\
(m r e m / h) /(p h o t o n / c m / s)\end{array}$ \\
\hline $1.00 \mathrm{E}-02$ & $2.232 \mathrm{E}-05$ & $5.00 \mathrm{E}-01$ & $9.144 \mathrm{E}-04$ \\
\hline $1.50 \mathrm{E}-02$ & $5.625 \mathrm{E}-05$ & $6.00 \mathrm{E}-01$ & $1.076 \mathrm{E}-03$ \\
\hline $2.00 \mathrm{E}-02$ & $8.568 \mathrm{E}-05$ & $8.00 \mathrm{E}-01$ & $1.379 \mathrm{E}-03$ \\
\hline $3.00 \mathrm{E}-02$ & $1.184 \mathrm{E}-04$ & $1.00 \mathrm{E}+00$ & $1.656 \mathrm{E}-03$ \\
\hline $4.00 \mathrm{E}-02$ & $1.314 \mathrm{E}-04$ & $1.50 \mathrm{E}+00$ & $2.246 \mathrm{E}-03$ \\
\hline $5.00 \mathrm{E}-02$ & $1.382 \mathrm{E}-04$ & $2.00 \mathrm{E}+00$ & $2.758 \mathrm{E}-03$ \\
\hline $6.00 \mathrm{E}-02$ & $1.440 \mathrm{E}-04$ & $3.00 \mathrm{E}+00$ & $3.672 \mathrm{E}-03$ \\
\hline $8.00 \mathrm{E}-02$ & $1.624 \mathrm{E}-04$ & $4.00 \mathrm{E}+00$ & $4.500 \mathrm{E}-03$ \\
\hline $1.00 \mathrm{E}-01$ & $1.919 \mathrm{E}-04$ & $5.00 \mathrm{E}+00$ & $5.292 \mathrm{E}-03$ \\
\hline $1.50 \mathrm{E}-01$ & $2.797 \mathrm{E}-04$ & $6.00 \mathrm{E}+00$ & $6.012 \mathrm{E}-03$ \\
\hline $2.00 \mathrm{E}-01$ & $3.708 \mathrm{E}-04$ & $8.00 \mathrm{E}+00$ & $7.488 \mathrm{E}-03$ \\
\hline $3.00 \mathrm{E}-01$ & $5.616 \mathrm{E}-04$ & $1.00 \mathrm{E}+01$ & $8.892 \mathrm{E}-03$ \\
\hline $4.00 \mathrm{E}-01$ & $7.416 \mathrm{E}-04$ & $1.20 \mathrm{E}+01$ & $1.040 \mathrm{E}-02$ \\
\hline
\end{tabular}

*ANS1/ANS, 1991, Neutron and Gamma-ray Fluence-to-dose Factors, ANSI/ANS-6.1.1-1991, American National Standards Institute/American Nuclear Society, New York, New York.

The photon source term is shown in Table B5-2 and was assumed to be homogeneously distributed throughout the volume of the samples. The solid tank waste was modeled as water with a density of $1.6 \mathrm{~g} / \mathrm{cc}$.

The 125-mL sample bottle has an outside diameter of approximately $5.5 \mathrm{~cm}$ and a height of $12.3 \mathrm{~cm}$. The $125-\mathrm{mL}$ sample was modeled as a cylinder with an outside diameter of $5.5 \mathrm{~cm}$ and a height of $5.26 \mathrm{~cm}$, which results in a sample size of $125 \mathrm{cc}$. The $125-\mathrm{mL}$ sample is placed in a "paint can," which is then placed into the Doorstop container, the DOT 208-L drum, and the N-55 overpack. The small amount of shielding provided by the paint can and sample bottle is ignored for this analysis. Figure B5-I shows the arrangement of the seven Doorstops in the DOT 208-L drum.

A maximum of two overpacks may be loaded on the truck at any one time (Figure B5-2). The overpacks are vertically oriented on the truck and are spaced apart by $15.24 \mathrm{~cm}$ ( $6 \mathrm{in}$.$) . The distance from the centerline of the$ overpacks to the side of the truck is $117 \mathrm{~cm}$ (3 $\mathrm{ft}, 10 \mathrm{in}$.), and the distance from the overpack centerline to the back of the truck is $146 \mathrm{~cm}$ ( $4 \mathrm{ft}$, $9.4 \mathrm{in.)}$. Therefore, the vehicle surface will be defined as the side of the truck in this analysis. The maximum dose rate at the side of the truck (vehicle surface) will occur between the front and rear overpacks when two overpacks are loaded on the truck. The distance from an overpack to a person located on the side of the truck at the midpoint between the front and rear overpacks is $126 \mathrm{~cm}$ (4 ft, $1.4 \mathrm{in.)}$. The driver is located $33 \mathrm{~cm}$ (13 in.) from the overpack that is located on the front end of the truck bed. For simplicity, a single N-55 was modeled in MCNP; however, the dose contributions from both overpacks will be accounted for in the dose rate calculations. 
HNF-SD-TP-SARP-023 Rev. 0

Figure B5-1. Arrangement of the Doorstop Containers in the $\mathbf{N}-55$.

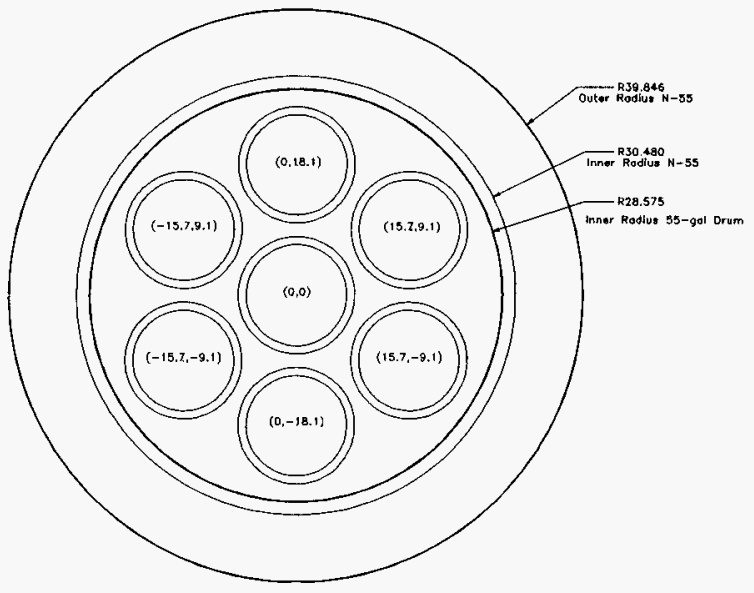

(Note: Dimensions in in.)

Figure B5-2. Simplified Sketch of Doorstop Sample Carrier System Transport Vehicle.

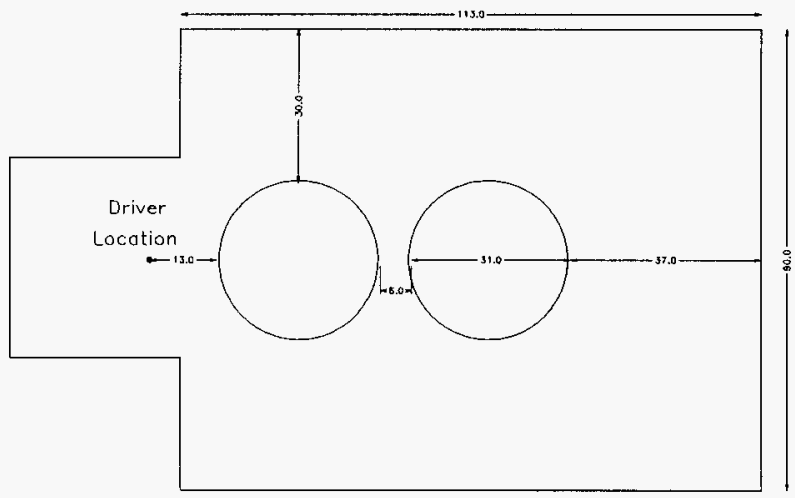

(Note: Dimensions in in.) 
Tables B5-4 and B5-5 summarize the radial and axial MCNP models.

Table B5-4. Doorstop Sample Carrier System Radial Geometry and Material Composition.

\begin{tabular}{|l|c|c|c|}
\hline \multicolumn{1}{|c|}{\begin{tabular}{c} 
Zone (material) \\
\hline \hline Source (water)
\end{tabular}} & $\begin{array}{c}\text { Outer radius } \\
\text { (cm) }\end{array}$ & $\begin{array}{c}\text { Thickness } \\
\text { (cm) }\end{array}$ & $\begin{array}{c}\text { Material density } \\
\text { (g/cc) }\end{array}$ \\
\hline Gap (air) & 2.750 & 2.750 & 1.6 \\
\hline Doorstop container (steel) & 6.985 & 4.235 & 0.00122 \\
\hline Polystyrene spacer (polystyrene) & 8.103 & 1.118 & 8.0 \\
\hline 55 -gal drum (steel) & 28.575 & $\mathrm{NA}^{\mathrm{B}}$ & $0.0288^{\mathrm{b}}$ \\
\hline Gap (air) & 28.706 & 0.131 & 8.0 \\
\hline $\mathrm{N}-55$ (polyurethane) & 30.480 & 1.774 & $1.22 \mathrm{E}-3$ \\
\hline $\mathrm{N}-55$ (steel) & 39.745 & 9.266 & $0.0481^{\mathrm{b}}$ \\
\hline
\end{tabular}

${ }^{a}$ The polystyrene spacer fills the volume between the seven Doorstops and the inner dimensions of the 55 -gal drum.

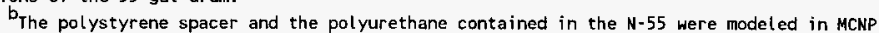
with a chemical composition of $\mathrm{CH}_{2}$. Due to the low densities of these materials, the results are very insensitive to the exact ${ }^{2}$ chenical form of the plastics.

\section{Tab7e B5-5. Doorstop Sample Carrier System Axial Geometry and Material Composition.}

\begin{tabular}{|c|c|c|c|}
\hline $\begin{array}{c}\text { Zone } \\
\text { (material) } \\
\end{array}$ & $\begin{array}{l}\text { MCNP top axial } \\
\text { plane }(\mathrm{cm}) \\
\end{array}$ & $\begin{array}{c}\text { Zone thickness } \\
(\mathrm{cm})\end{array}$ & $\begin{array}{c}\text { Material density } \\
(g / C c)\end{array}$ \\
\hline N-55 lid (steel) & 77.732 & 0.101 & 8.0 \\
\hline N-55 (polyurethane) & 77.631 & 17.78 & $0.0481^{a}$ \\
\hline Drum Lid (steel) & 59.851 & $0.161^{b}$ & 8.0 \\
\hline Polystyrene spacer (polystyrene) & 59.690 & 32.555 & $0.0288^{a}$ \\
\hline Top of Doorstop (steel) & 27.135 & 1.024 & 8.00 \\
\hline Gap (air) & 26.111 & 19.581 & $1.22 E-3$ \\
\hline Top of source (water) & 6.530 & 5.260 & 1.6 \\
\hline Bottom of Doorstop & 1.270 & 1.270 & 8.00 \\
\hline Polystyrene spacer (polystyrene) & 0.000 & 24.765 & $0.0288^{a}$ \\
\hline 55-gal drum (steel) & -24.765 & 0.131 & 8.00 \\
\hline N-55 (polyurethane) & -24.896 & 14.000 & $0.0481^{a}$ \\
\hline N-55 bottom/inside (steel) & -38.896 & 0.101 & 8.00 \\
\hline Bottom plane of $\mathrm{N}-55$ (steel) & -38.997 & NA & NA \\
\hline
\end{tabular}

MCNP = Monte Carlo N-Particle (computer code).

aThe polystyrene spacer and the polyurethane contained in the N-55 were modeled in MCNP with a chemical composition of $\mathrm{CH}_{2}$. Note that due to the low densities of these materials, the results are very insensitive to the exact chemical form of the plastics.

The small air gap between the 55 -gallon drum lid and the $\mathrm{N}-55$ is ignored. 


\subsubsection{Shielding Calculations}

Table B5-6 shows the gamma dose rate estimates from MCNP for various distances from the N-55 overpack for each of the two source terms. MCNP was only run for $875 \mathrm{~mL}$ of the worst-case tank solids. The results for $875 \mathrm{~mL}$ of the maximum expected source term were calculated by taking the values for $875 \mathrm{~mL}$ of the worst-case tank solids and multiplying by a factor of 0.054 . This factor (0.054) was derived at by dividing $200 \mathrm{mrem} / \mathrm{h}$ by $3700 \mathrm{mrem} / \mathrm{h}$, which is the maximum expected surface dose rate divided by the calculated dose rate for $875 \mathrm{~mL}$ of the worst-case tank solids. Because the two source term activities are only different by a factor of 0.054 , the resulting dose rates from MCNP will differ by the same factor.

Tab7e B5-6. Dose Rates Outside the Doorstop Sample Carrier System, mSv/h (mrem/h).

\begin{tabular}{|c|c|c|c|}
\hline \multicolumn{2}{|c|}{ Detector location } & $\begin{array}{c}875 \mathrm{~mL} \text { of maximum } \\
\text { expected source term }\end{array}$ & $\begin{array}{c}875 \mathrm{~mL} \text { of worst case } \\
\text { solids source term }\end{array}$ \\
\hline \hline \multirow{2}{*}{$\begin{array}{c}\text { overpack } \\
\text { surface }\end{array}$} & Side & $2.0(200)$ & $37.0(3700)$ \\
\cline { 2 - 4 } & Top & $0.54(54)$ & $10.0(1000)$ \\
\hline Bottom & $1.7(170)$ & $29.0(2900)$ \\
\hline Vehicle surface a & $0.29(29)$ & $5.4(540)$ \\
\hline 2 m from vehicle surface & $0.041(4.1)$ & $0.76(76)$ \\
\hline Driver location & $0.48(48)$ & $8.9(890)$ \\
\hline
\end{tabular}

1 sievert $=100 \mathrm{rem}$

Dose rate at the limiting location on the side of the truck bed.

briver located $13 \mathrm{in}$. from the overpack on the front end of the truck bed.

\subsection{ACCIDENT CONDITIONS}

\subsubsection{Conditions To Be Evaluated}

Testing was performed on the $\mathrm{N}-55$ overpack, and it was found that the overpack lid maintained its integrity even after a $9-\mathrm{m}(30-\mathrm{ft})$ drop test. The structural analysis indicates that the Doorstop Sample Carrier System also maintains its integrity after the drop. Therefore, there is no credible scenario that could occur during onsite shipment of the $\mathrm{N}-55$ that would result in the loss of the lid or the loss of any shielding provided by the N-55, DOT 208-L drum, or Doorstop container. However, the N-55 overpack experienced permanent deformation from each of the three drop tests (end, side, and corner). The deformation resulted from some of the material of the spacer assembly being crushed during impact. This deformation will cause a slight decrease in the distance from the source to the overpack surface, which, in turn, will cause a slight increase in the dose rates. Figure 7.6.1.4-1 shows the amount of damage resulting from each of the drop tests. The side drop, which resulted in approximately $5.08 \mathrm{~cm}$ (2 in.) of damage to the $\mathrm{N}-55$, will cause the greatest dose rate increase. Because the maximum dose rate during 
HNF-SD-TP-SARP-023 Rev. 0

normal conditions occurs on the side of the cask, the dose rates at the side of the cask will also be limiting after the drop tests.

\subsubsection{Acceptance Criteria}

The external dose rate from a single package shall not exceed $10 \mathrm{mSv} / \mathrm{h}$ $(1000 \mathrm{mrem} / \mathrm{h})$ at $1 \mathrm{~m}$ from the surface under accident conditions as directed by the onsite transportation safety program.

\subsubsection{Shielding Model}

The maximum dose rate at the vehicle surface during normal conditions of transfer is $0.29 \mathrm{mSv} / \mathrm{h}$ (29 mrem/h [see Table B5-7]) for the maximum expected source term. The location of the maximum vehicle surface dose rate is $126 \mathrm{~cm}$ from the surface of the overpack, and since two overpacks contribute to the dose rate at that location, the dose rate from a single overpack is $0.15 \mathrm{mSv} / \mathrm{h}$ $(15 \mathrm{mrem} / \mathrm{h})$. The radial dose at approximately $1 \mathrm{~m}$ from the overpack is decreasing at a rate slightly greater than $1 / r$, where $r$ is the distance. Therefore, the dose rate at $1 \mathrm{~m}$ is conservatively estimated to be $0.19 \mathrm{mSv} / \mathrm{h}$ $(19 \mathrm{mrem} / \mathrm{h}=15 \mathrm{mrem} / \mathrm{h} \times 1.26 \mathrm{~m} / 1 \mathrm{~m})$. For the side drop case the distance from the overpack will decrease by $5.08 \mathrm{~cm}$ (2 in.), which corresponds to a distance of $0.95 \mathrm{~m}$ from the overpack. The dose rate at $0.95 \mathrm{~m}$, which corresponds to $1 \mathrm{~m}$ from the damaged package, is conservatively estimated to be $0.20 \mathrm{mSv} / \mathrm{h}(20 \mathrm{mrem} / \mathrm{h}=15 \mathrm{mrem} / \mathrm{h} \times 1.26 \mathrm{~m} / 0.95 \mathrm{~m})$, which is far below the $10-\mathrm{mSv} / \mathrm{h}(1000-\mathrm{mrem} / \mathrm{h})$ limit at $1 \mathrm{~m}$ from the surface under accident conditions.

Similarly, for the worst-case solids source term, the resulting dose rate at $0.95 \mathrm{~m}$ is approximately $3.7 \mathrm{mSv} / \mathrm{h}(370 \mathrm{mrem} / \mathrm{h})$, which al so meets the $10-\mathrm{mSv} / \mathrm{h}(1000-\mathrm{mrem} / \mathrm{h})$ limit at $1 \mathrm{~m}$ under accident conditions.

\subsection{SHIELDING EVALUATION AND CONCLUSIONS}

Table B5-7 shows the results of the shielding analysis. The dose rates for $875 \mathrm{~mL}$ of the maximum expected source term meets all of the limits except for the dose rate at the driver location. Additional shielding is required to reduce the dose rate at the driver location below the required limit. All of the dose rates for normal operating conditions exceed the limits for the shipment of $875 \mathrm{~mL}$ of the worst-case solids. When the allowable dose rates are exceeded, the administrative controls outlined in Part A, Section 6.0, will be enforced. 
Table B5-7. Comparison of Maximum Dose Rates, $\mathrm{mSv} / \mathrm{h}(\mathrm{mrem} / \mathrm{h})$, with Dose Rate Limits.

\begin{tabular}{|c|c|c|c|}
\hline Detector location & Limit & $\begin{array}{l}875 \mathrm{~mL} \text { of maximum } \\
\text { expected source term }\end{array}$ & $\begin{array}{l}875 \mathrm{~mL} \text { of worst-case } \\
\text { solid tank waste }\end{array}$ \\
\hline \multicolumn{4}{|c|}{ Normal operating conditions } \\
\hline Overpack surface & $2(200)$ & $2.0(200)$ & $37.0^{c}(3700)$ \\
\hline Vehicle surface ${ }^{a}$ & $2(200)$ & $0.29(29)$ & $5.4^{c}(540)$ \\
\hline $2 \mathrm{~m}$ from vehicle surface & $0.1(10)$ & $0.041(4.1)$ & $0.76^{c}(76)$ \\
\hline Driver location ${ }^{b}$ & $0.05(5)$ & $0.48^{c}(48)$ & $8.9^{c}(890)$ \\
\hline \multicolumn{4}{|c|}{ Accident conditions } \\
\hline $\begin{array}{l}1 \mathrm{~m} \text { from overpack } \\
\text { surface }\end{array}$ & $10.0(1000)$ & $0.20(20)$ & $3.7(370)$ \\
\hline
\end{tabular}

1 sievert $=100 \mathrm{rem}$

${ }^{a}$ Dose rate at the limiting location on the side of the truck bed.

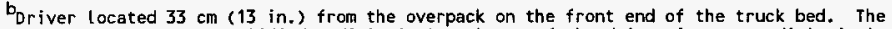
$5-\mathrm{mrem} / \mathrm{h}$ limit applies to a qualified radiological worker. If the driver is a nonradiological worker, the dose rate limit is $2 \mathrm{mrem} / \mathrm{h}$.

$C$ Additional shielding will be used to reduce the dose rates below the required limits (see Part A, Section 6.0).

\subsection{REFERENCES}

ANSI/ANS, 1991, Neutron and Gamma-ray Fluence-to-dose Factors, ANSI/ANS-6.1.11991, American National Standards Institute/American Nuclear Society, New York, New York.

Breismeister, J. F., Editor, 1993, MCNP--A General Monte Carlo Code N-Particle Transport Code, Version 4a, LA-12625, Los Alamos National Laboratory, Los Alamos, New Mexico.

Carter, L. L., 1995, Certification of Version $4 A$ for WHC Computer Platforms, WHC-SD-MP-SWD-30001, Rev. 7, Westinghouse Hanford Company, Richland, Washington.

Nelson, J. V., 1996, Estimation of Neutron Dose Rates from Nuclear Waste Packages (internal memo 8M730-JVN-96-007 to J. R. Green, March 8), Westinghouse Hanford Company, Richland, Washington.

Schmittroth, F. A., 1994, Conversion of ORIGEN2 to the Sun Workstations, WHC-SD-NR-SWD-006, Rev. 1, Westinghouse Hanford Company, Richland, Washington. 
HNF-SD-TP-SARP-023 Rev. 0

\subsection{APPENDICES}

5.8.1 Listing of ORIGEN2 Input File for $875 \mathrm{~mL}$ of Worst-Case Source Term

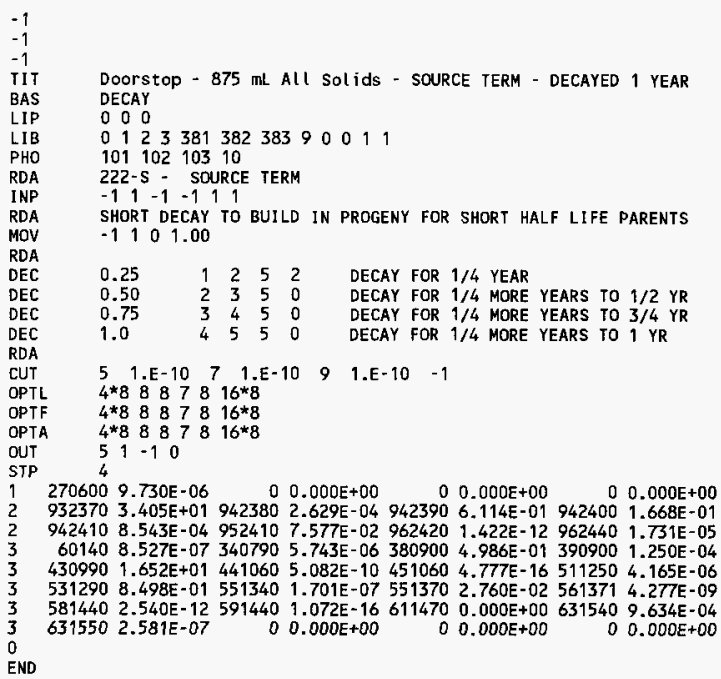




\subsubsection{Listing of MCNP Input File}

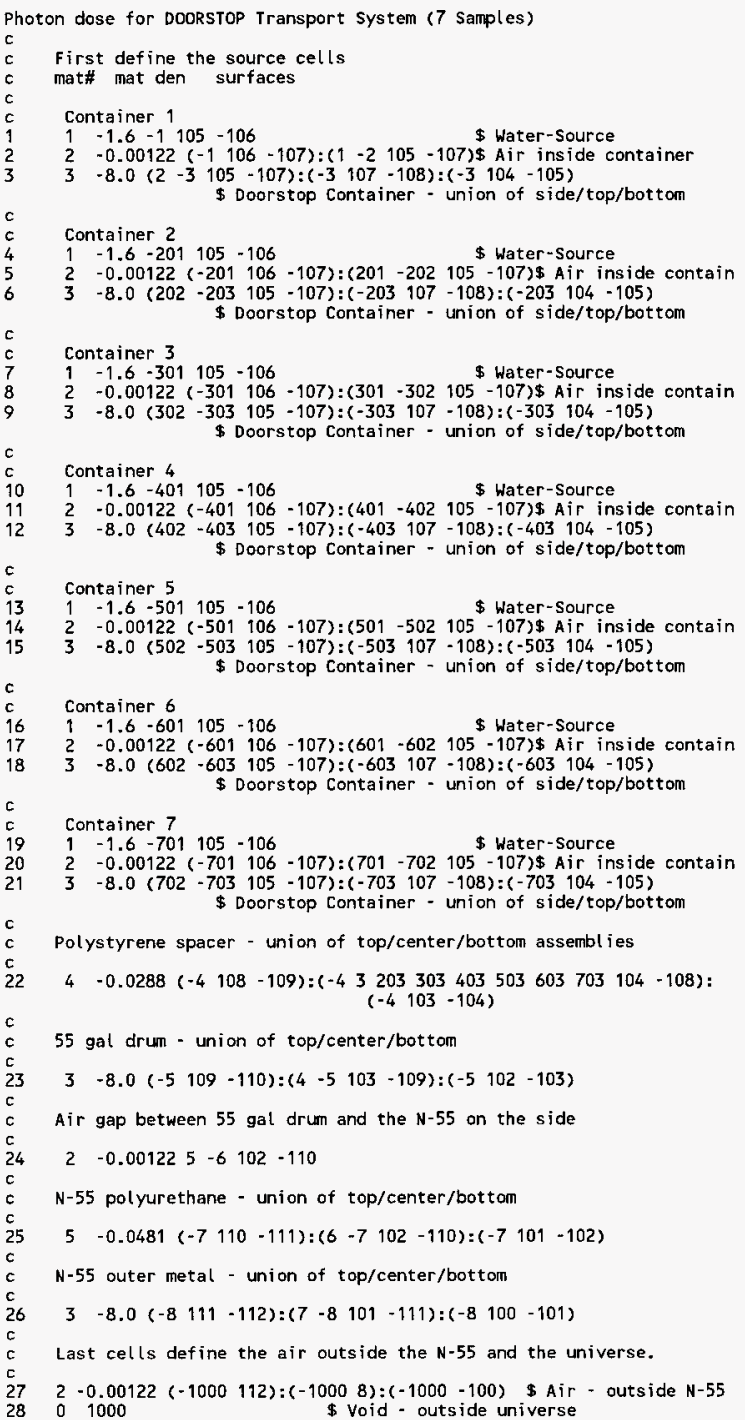


HNF-SD-TP-SARP-023 Rev. 0

Radial surfaces for Container 1

c2 2.75 Container 1 - source - outside radius

c2 6.985 Container 1 - inside radius of Doorstop

cz 8.103 Container 1 - outside radius of Doorstop

Radial surfaces for 55 gal drum and N-55 Overpack

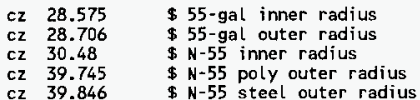

Axial surfaces

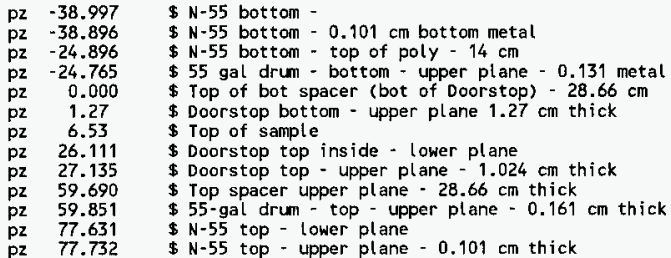

Source radial surfaces for Containers 2 - 7 with translation

701 cz 2.75 Container 2 - source - outside radius

701 cz 6.985 Container 2 - inside radius of Doorstop

701 cz 8.103 Container 2 - outside radius of Doorstop

702 cz 2.75 Container 3 - source - outside radius

702 Cz 6.985 Container 3 - inside radius of Doorstop

702 Cz 8.103 \$ Container 3 - outside radius of Doorstop

703 c2 2.75 \& Container 4 - source - outside radius

703 CZ 6.985 \$ Container 4 - inside radius of Doorstop

703 Cz 8.103 \$ Container 4 - outside radius of Doorstop

704 cZ 2.75 \$ Container 5 - source - outside radius

704 cz 6.985 Container 5 - inside radius of Doorstop

704 cz 8.103 Container 5 - outside radius of Doorstop

$705 \mathrm{cz} 2.75$ Container 6 - source - outside radius

$705 \mathrm{cz} 6.985$ Container 6 - inside radius of Doorstop

705 cz $8.103 \$$ Container 6 - outside radius of Doorstop

706 cz 2.75 \$ Container 7 - source - outside radius

$706 \mathrm{cz} 6.985$ \$ Container 7 - inside radius of Doorstop

$706 \mathrm{cz} 8.103 \$$ Container 7 - outside radius of Doorstop

1000 so 500 . \$air universe

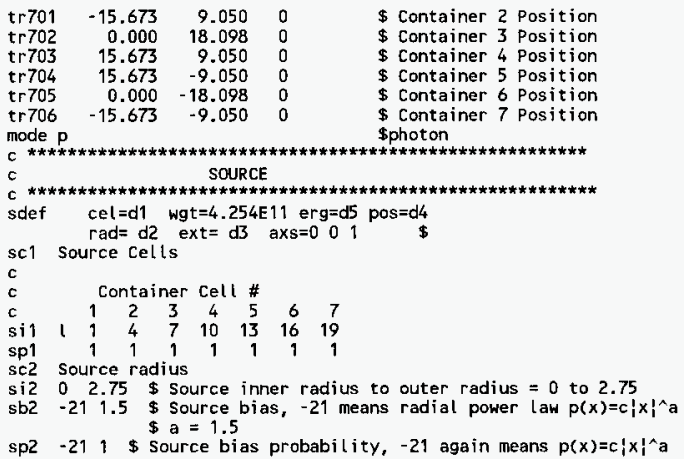




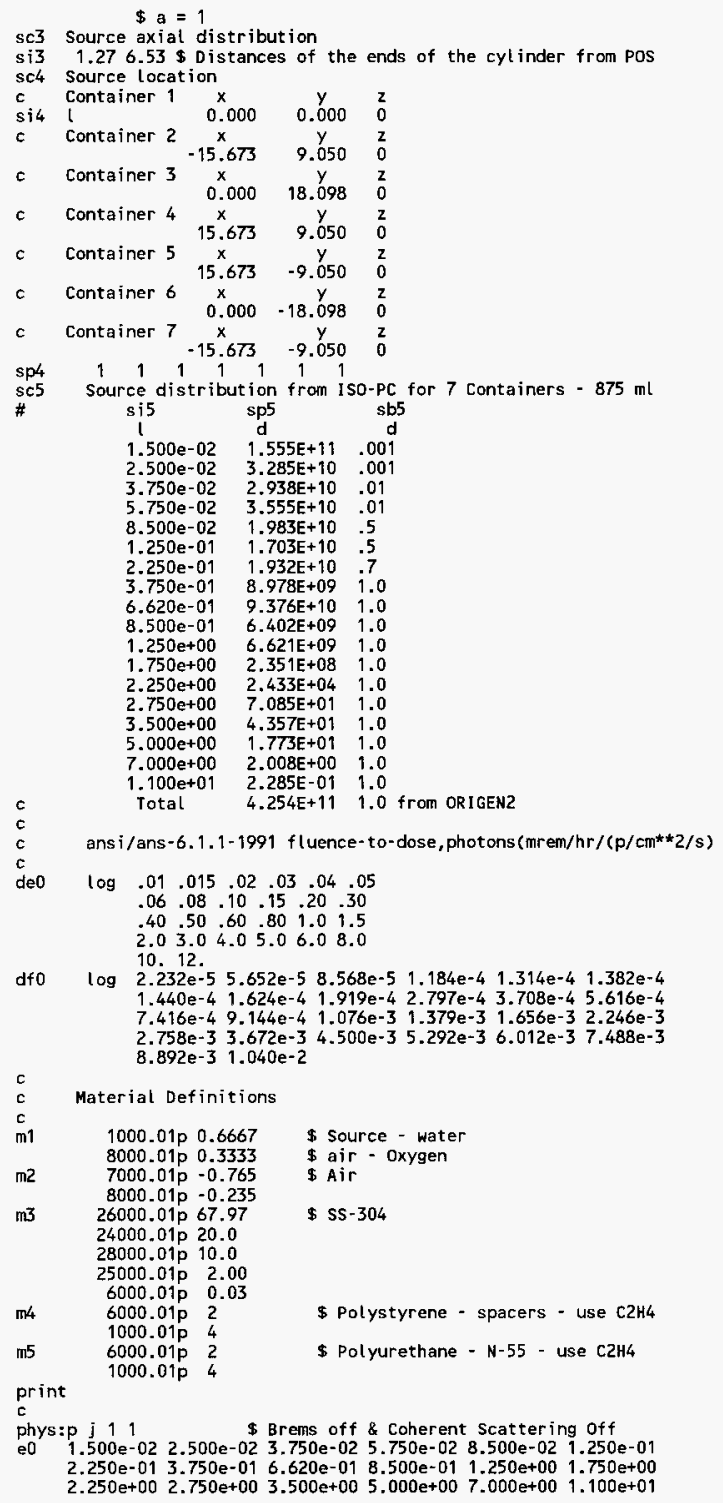




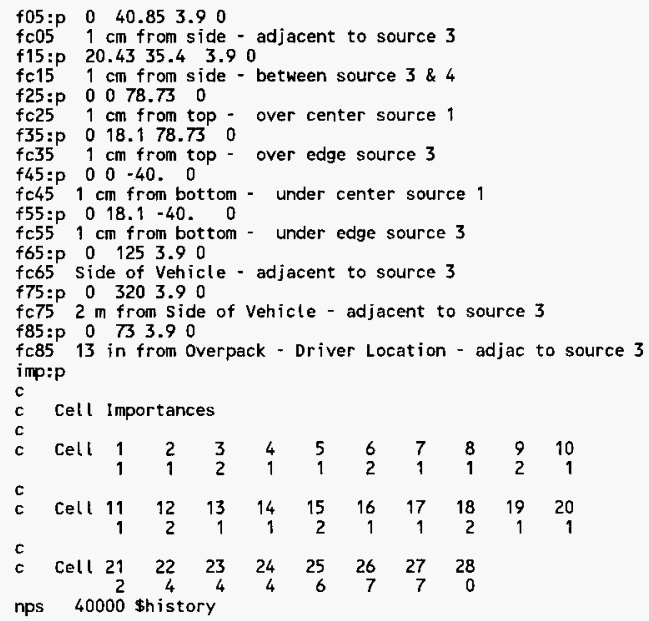


HNF-SD-TP-SARP-023 Rev. 0

\section{CHECKLIST FOR PEER REVIEH}

Document Reviewed: Shielding Analys is for the Doorstop SARP

Scope of Review: Entire shielding analysis - Section 5.0

$\frac{\text { Yes No NA }}{[X][][]}$

$\left.\begin{array}{lll}{[x]} & {[]} & {[]} \\ {[x]} & {[]} & {[} \\ x] & {[} & {[} \\ b] & {[]} & {[} \\ {[x]} & {[]} & {[}\end{array}\right]$

[ ] $[$ ] $[x]$

[x] [ ] [ ]

[x] [ ] [ ]

$[\times][][1]$

Previous reviews complete and cover analysis, up to scope of this review, with no gaps.

\section{Problem completely defined.}

Accident scenarios developed in a clear and logical manner. Necessary assumptions explicitly stated and supported.

Computer codes and data files documented.

Data used in calculations explicitly stated in document.

Data checked for consistency with original source information as applicable.

Mathematical derivations checked including dimensional consistency of results.

Models appropriate and used within range of validity or use outside range of established validity justified.

hand calculations checked for errors. Spreadsheet results should be treated exactly the same as hand calculations.

Software input correct and consistent with document reviewed.

Software output consistent with input and with results reported in document reviewed.

[x] [ ] [ ] Limits/criteria/guidelines applied to analysis results are appropriate and referenced. Limits/criteria/guidelines checked against references.

$[x][][]$

Safety margins consistent with good engineering practices. Conclusions consistent with analytical results and applicable limits.

[x] [ ] [ ] Results and conclusions address all points required in the problem statement.

CX] [ ] [ ] Format consistent with appropriate NRC Regulatory Guide or other standards

[] [ $]$ ] Review calculations, comments, and/or notes are attached.

[X] [ ] [ ] Document approved.

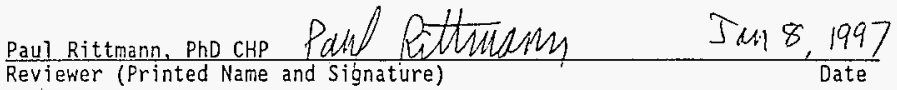


HNF-SD-TP-SARP-023 Rev. 0

\subsection{CRITICALITY EVALUATION}

\subsection{DISCUSSION AND RESULTS}

Table B6-1 shows the calculations to determine the fissile content of the Doorstop Sample Carrier System. The activities for the radionuclides identified as fissile in 49 CFR $173.403(j)$ are included along with their specific activities from 49 CFR 173.435.

The quantity (g) of each fissile radionuclide is listed in Table B6-1. These values were calculated by dividing the radionuclide activity ( $C i$ ) by its specific activity $(\mathrm{C} / \mathrm{g})$. Table $\mathrm{B} 6-1$ shows that the total quantity of fissile material contained in the Doorstop Sample Carrier System is $3.2 \times 10^{-2} \mathrm{~g}$ for the maximum expected source term and $6.1 \times 10^{-1} \mathrm{~g}$ for the worst-case source term. Since the total quantity of fissile material is less than $15 \mathrm{~g}$ for both source terms, the Doorstop Sample Carrier System is exempt from fissile material classification (10 CFR 71.53), and no further analysis is required to address criticality concerns.

Table B6-1. Doorstop Sample Carrier System Fissile Inventory.

\begin{tabular}{|l|c|c|c|c|c|}
\hline \multirow{2}{*}{ Nucl ide } & \multicolumn{2}{|c|}{ Activity (Ci) } & \multirow{2}{*}{$\begin{array}{c}\text { Specific } \\
\text { activity }\end{array}$} & \multicolumn{2}{c|}{ Quantity (g) } \\
\cline { 2 - 3 } & $\begin{array}{c}\text { Maximum } \\
\text { expected }\end{array}$ & $\begin{array}{c}\text { Worst } \\
\text { case }\end{array}$ & (Ci/g)* & $\begin{array}{c}\text { Maximum } \\
\text { expected }\end{array}$ & $\begin{array}{c}\text { Worst } \\
\text { case }\end{array}$ \\
\hline \hline $238 \mathrm{Pu}$ & $2.4 \mathrm{E}-04$ & $4.5 \mathrm{E}-03$ & $1.7 \mathrm{E}+01$ & $1.4 \mathrm{E}-05$ & $2.7 \mathrm{E}-04$ \\
\hline $239 \mathrm{Pu}$ & $2.0 \mathrm{E}-03$ & $3.8 \mathrm{E}-02$ & $6.2 \mathrm{E}-02$ & $3.2 \mathrm{E}-02$ & $6.1 \mathrm{E}-01$ \\
\hline $241 \mathrm{Pu}$ & $4.7 \mathrm{E}-03$ & $8.8 \mathrm{E}-02$ & $1.0 \mathrm{E}+02$ & $4.7 \mathrm{E}-05$ & $8.8 \mathrm{E}-04$ \\
\hline \hline Total & $6.9 \mathrm{E}-03$ & $1.3 \mathrm{E}-01$ & $\mathrm{NA}$ & $3.2 \mathrm{E}-02$ & $6.1 \mathrm{E}-01$ \\
\hline
\end{tabular}

*Specific activities taken from 49 CFR 173.435, 1995, "Shippers--General Requirements for Shipments and Packagings, Code of Federal Regulations, as amended.

\subsection{REFERENCES}

10 CFR 71, 1995, "Packaging and Transportation of Radioactive Material," Code of Federal Regulations, as amended.

49 CFR 173, 1995, "Shippers--General Requirements for Shipments and Packagings," Code of Federal Regulations, as amended. 
HNF-SD-TP-SARP-023 Rev. 0

This page intentionally left blank. 
HNF-SD-TP-SARP-023 Rev. 0

\subsection{STRUCTURAL EVALUATION}

\subsection{INTRODUCTION}

This section presents the structural analysis of the Doorstop Sample Carrier system and all associated lifting attachments. Tiedown assemblies are discussed in Part B, Section 10.0, since they are not a structural part of the package. This section demonstrates the Doorstop Sample Carrier System meets the intent of 10 CFR 71 requirements based on the analyses herein and drop testing performed on the package (WHC 1995).

\subsection{STRUCTURAL EVALUATION OF PACKAGE}

\subsubsection{Structural Design and Features}

As discussed in Part A, Section 2.0, the Doorstop Sample Carrier System consists of multiple packagings. Of those multiple packagings, two constitute a Type B NRC-certified packaging (USA/9070/B(U)): the DOT 208-L drum and the $\mathrm{N}-55$ overpack. The inner container is an onsite container used to transport onsite tank waste samples.

The primary containment for the Doorstop Sample Carrier System is the Doorstop container. The DOT 208-L drum is considered secondary containment in this system. The $\mathrm{N}-55$ overpack acts as an impact limiter in the Doorstop Sample Carrier System. The foam inner spacer around the Doorstop container inside the DOT 208-L drum provides additional cushioning.

The Doorstop container is sealed with a Neoprene 0-ring and threaded top closure. The DOT 208-L drum is sealed with a NEOZAN gasket and a bolted lock ring is tightened around the outside of the drum 1id. The $\mathrm{N}-55$ overpack has a Neoprene gasket at the stepped joint between the upper and lower section of the overpack. Four toggle clamps on the outside of the $\mathrm{N}-55$ overpack connect the upper and lower sections.

\subsubsection{Mechanical Properties of Materials}

Mechanical properties of the materials are shown in Table B7-1. 
Table B7-1. Mechanical Properties of Materials.

\begin{tabular}{|c|c|c|c|c|}
\hline Material description & $\begin{array}{c}\text { Temperature } \\
{ }^{\circ} \mathbf{C}\left({ }^{\circ} \mathbf{F}\right) \\
\end{array}$ & $\begin{array}{l}\text { Yield S } \\
\mathrm{MPa}(\mathrm{ks} \text { ) }\end{array}$ & $\begin{array}{l}\text { ULtimate } S_{\mathrm{U}} \\
\mathrm{MPa} \text { (ksi) }\end{array}$ & $\begin{array}{l}\text { Allowable } \mathrm{S}_{\mathrm{m}} \\
\mathrm{MPa}(\mathrm{ks} \text { ) }\end{array}$ \\
\hline Galvanized steel & $\begin{array}{l}38(100) \\
93(200) \\
149(300)\end{array}$ & $248(36)$ & $414(60)$ & $\begin{array}{l}110(16) \\
110(16) \\
110(16) \\
\end{array}$ \\
\hline $\begin{array}{l}\text { ASTM A312 304L } \\
\text { stainless steel pipe }\end{array}$ & $\begin{array}{l}38(100) \\
93(200) \\
149(300)\end{array}$ & $\begin{array}{l}172(25) \\
148(21) \\
132(19)\end{array}$ & $\begin{array}{c}483(70) \\
456(66.2) \\
420(60.9)\end{array}$ & $\begin{array}{l}115(16.7) \\
115(16.7) \\
115(16.7)\end{array}$ \\
\hline $\begin{array}{l}\text { * ASTM A276 } 304 \mathrm{~L} \\
\text { stainless steel rod }\end{array}$ & $\begin{array}{c}38(100) \\
93(200) \\
149(300) \\
\end{array}$ & $\begin{array}{l}172(25) \\
148(21) \\
132(19) \\
\end{array}$ & $\begin{array}{l}483(70) \\
456(66.2) \\
420(60.9) \\
\end{array}$ & $\begin{array}{l}115(16.7) \\
98.6(14.3) \\
88.3(12.8) \\
\end{array}$ \\
\hline $\begin{array}{l}\text { ASTM A240 304L } \\
\text { stainless steel plate }\end{array}$ & $\begin{array}{l}38(100) \\
93(200) \\
149(300)\end{array}$ & $\begin{array}{c}172(25) \\
147(21.3) \\
132(19.1) \\
\end{array}$ & $\begin{array}{c}483(70) \\
456(66.2) \\
420(60.9) \\
\end{array}$ & $\begin{array}{l}115(16.7) \\
115(16.7) \\
115(16.7) \\
\end{array}$ \\
\hline Lead & $\begin{array}{c}38(100) \\
93(200) \\
149(300)\end{array}$ & $\begin{array}{l}120(827.4) \\
114.6(790) \\
110.7(763)\end{array}$ & $135(931)$ & \\
\hline
\end{tabular}

ASTM = American Society for Testing and Materials.

* = ASTM A479 values used as a conservative equivalent.

All vatues from ASME, 1995, American Society of Mechanical Engineers Boiler and Pressure Vessel Code, Section II, American Society of Mechanical Engineers, New York, New York.

\subsubsection{Chemical and Galvanic Reactions}

The materials of fabrication for the containment vessel, Doorstop container (i.e., stainless steel, lead, and Viton) will not cause significant chemical, galvanic, or other reactions with each other or with the contents.

\subsubsection{Size of Package and Cavity}

The overail size of the package is detailed in Part A, Section 2.0. The size of the contents cavity is the cavity of the Doorstop container, which is $14 \mathrm{~cm}$ (5.5 in.) inside diameter by $22.56 \mathrm{~cm}(8.88 \mathrm{in.}) \mathrm{high}$.

\subsubsection{Weights and Centers of Gravity}

The approximate weight of each component of the Doorstop Sample Carrier System is as shown in Table B7-2. 
HNF-SD-TP-SARP-023 Rev. 0

Table B7-2. Doorstop Sample Carrier System Weights.

\begin{tabular}{|l|c|}
\hline \multicolumn{1}{|c|}{ Component } & $\begin{array}{c}\text { Weight } \\
\mathrm{kg}(\mathrm{lb})\end{array}$ \\
\hline \hline Overpack & $90.7(200)$ \\
\hline Drum with padding & $30.4(67)$ \\
\hline Seven Doorstop containers & $101.6(224)$ \\
\hline Seven Doorstops & $101.6(224)$ \\
\hline \hline TOTAL & $324(715)$ \\
\hline
\end{tabular}

The total weight of the Doorstop Sample Carrier System with seven Doorstops is $324 \mathrm{~kg}$ (715 1b) with the center of gravity located on the vertical centerline of the cask $55.3 \mathrm{~cm}$ (21.78 in.) from the bottom.

\subsubsection{Tamper Indicating Feature}

The $\mathrm{N}-55$ overpack tamper-indicating feature is evidence tape which is placed over the joint between the top and bottom overpack shells. When intact, the seal provides evidence that the package has not been opened by unauthorized persons.

\subsubsection{Positive Closure}

The Doorstop Sample Carrier System must have a positive fastening device which cannot be inadvertently opened [10 CFR 71.43(c)]. The Doorstop container has a screw top lid that cannot be reached from outside the N-55 overpack. The DOT 208-L drum lid has a locking ring bolt that is torqued to $54.23 \mathrm{~N}-\mathrm{m}$ (40 ft-1b). The $\mathrm{N}-55$ overpack is securely closed with four toggle clamps. Past use of the toggle clamps has resulted in damage to the fiber glass inner shell of the $\mathrm{N}-55$ overpack. To avoid damage in the future, the closure instructions for the overpack were modified. See Part B, Section 7.6.1.6 for the evaluation on the closure procedure used for activation of the toggle clamps.

\subsubsection{Lifting and Tiedown Devices}

The four lifting locations on the $\mathrm{N}-55$ overpack have previously been approved for a gross weight of $341 \mathrm{~kg}(750 \mathrm{lb})$ (NuPac 1987). The Doorstop Sample Carrier System authorized gross weight of $273 \mathrm{~kg}$ (600 1b) is lower; therefore, the lifting locations meet the 10 CFR 71.45 (a) requirement.

In the past, some $\mathrm{N}-55$ overpacks exhibited a loosening of the rivets used to secure the lift lugs to the overpack. To avoid the problem, the lugs are not used to lift the entire package. In place of the lifting lugs, an arrangement was designed for use in both tying down and lifting the package. The lifting and tiedown yoke arrangements (drawing $\mathrm{H}-2-99129$ in Part $\mathrm{A}$, Section 10.1 ) has been shown to meet the lifting arrangement. The arrangement 


$$
\text { HNF-SD-TP-SARP-023 Rev. } 0
$$

is used when lifting the package onto and off of the transporter (Part B, Section 6.1.2).

There are no tiedown devices that are a structural part of the package. The tiedown method used is evaluated in Part B, Section 10.0.

\subsubsection{Brittle Fracture}

The Doorstop container and Doorstop sample carriers are made of austenitic stainless steels and lead. The steel remains ductile at $-40{ }^{\circ} \mathrm{C}$ $\left(-40^{\circ} \mathrm{F}\right)$ [10 CFR $\left.71.71(\mathrm{c})(2)\right]$. Lead is not susceptible to brittle fracture at this temperature. The 0-ring for the Doorstop container is fabricated of Neoprene which has a performance temperature range of $-55^{\circ} \mathrm{C}\left(-67{ }^{\circ} \mathrm{F}\right)$ through $140{ }^{\circ} \mathrm{C}\left(284{ }^{\circ} \mathrm{F}\right)$.

\subsection{NORMAL TRANSFER CONDITIONS}

\subsubsection{Conditions to be Evaluated}

The NCT per 10 CFR 71 list conditions to be evaluated and their acceptance criteria. The following conditions evaluated are scenarios and tests to simulate the affects NCT have on the package.

- Free drop from $1.2 \mathrm{~m}(4 \mathrm{ft})$ onto an unyielding surface in an orientation as to cause maximum damage.

- Vibration normally incident to transportation.

- The application of a uniform load of five times the package weight in the orientation of transport.

- Penetration of a $6 \mathrm{~kg}(13 \mathrm{lb}), 3.2 \mathrm{~cm}$ (1.25 in.) diameter rod $101.6 \mathrm{~cm}$ (40 in.) onto the package.

- The application of water spray that simulates rainfall of approximately $5.08 \mathrm{~cm}$ (2 in.) per hour for a least one hour.

The above loading cases must be applied with both hot and cold environmental conditions, and in combination with the increased and decreased external pressurization.

\subsubsection{Acceptance Criteria}

Under the NCT 1isted above, it must be demonstrated that the Doorstop container maintains the containment leak rate to $5.81 \times 10^{-5} \mathrm{std}-\mathrm{cc} / \mathrm{s}$ or less, and shielding of the radioactive material sample.

Criteria based on the NRC Regulatory Guides require the Doorstop container stresses to remain elastic, with adequate safety margins. The allowable stresses were determined per the ASME BPVC, Section II. 
HNF-SD-TP-SARP-023 Rev. 0

\subsubsection{Structural Mode1}

Conservative, classical methods of analysis were used to evaluate the stresses induced in the Doorstop container during NCT. Classical modeling techniques were also used in conjunction with the analytical methods. Free body diagrams and text throughout the analyses (Part B, Section 7.6) explain how each type of loading was modeled and evaluated. Cask drop models (PacTec) were used to determine the $g$-loading based on the crush from the $9 \mathrm{~m}$ ( $30 \mathrm{ft}$ ) drop testing. Although, the $9 \mathrm{~m}(30 \mathrm{ft})$ drop is an accident condition, it is a worst-case drop and therefore is used to demonstrate the $1.2 \mathrm{~m}$ ( $4 \mathrm{ft}$ ) requirement is met.

\subsubsection{Initial Conditions}

The Doorstop Sample Carrier System was evaluated per 10 CFR 71 conditions (NuPac 1987) and Hanford Site conditions (Part B, Section 8.0). The initial condition stresses due to thermal loading are added to the NCT.

Per 10 CFR 71, the initial conditions for NCT for analysis are defined as ambient temperatures between $-40^{\circ} \mathrm{C}\left(-40{ }^{\circ} \mathrm{F}\right)$ and $37.3{ }^{\circ} \mathrm{C}\left(100^{\circ} \mathrm{F}\right)$. Hanford ambient temperatures are between and $-32.7^{\circ} \mathrm{C}\left(-27^{\circ} \mathrm{F}\right)$ and $46.11^{\circ} \mathrm{F}\left(115^{\circ} \mathrm{F}\right)$. The initial internal pressure within the containment system must be considered to be the maximum normal operating pressure, unless a lower internal pressure consistent with the ambient temperature considered to precede and follow the test is more unfavorable.

\subsubsection{Environmental Heat Loading.}

7.3.4.1.1 Hot. The "hot" heat loading required to be evaluated for onsite packages is at $46.1{ }^{\circ} \mathrm{C}\left(115^{\circ} \mathrm{F}\right)$ in still air with solar insolation.

The maximum Doorstop container seal temperature due to insolation and decay heat is $139{ }^{\circ} \mathrm{C}\left(282^{\circ} \mathrm{F}\right)$. Stresses in the wall of the Doorstop container are negligible due to this temperature rise.

7.3.4.1.2 cold. The "cold" heat loading required to be evaluated for onsite packages is at $-32.77^{\circ} \mathrm{C}\left(-27^{\circ} \mathrm{F}\right)$ in still air and shade.

The temperatures of the Doorstop container will reach $-32.77{ }^{\circ} \mathrm{C}\left(-27{ }^{\circ} \mathrm{F}\right)$ during steady state for this condition. Stresses due to this temperature are also negligible in the Doorstop container.

7.3.4.2 Maximum Pressure Stresses. Calculations and testing were performed to determine resulting stresses encountered on the end plate, cylinder wall, and welds of the Doorstop Container when subjected to a reduced external pressure of 3.5 psa absolute (Part B, Section 7.6.1.3). All results of calculations show a large margin of safety over the allowable limits.

Calculations were performed to determine pressure encountered on the Doorstop Container end plate, cylinder walls, and welds if subjected to an increased external pressure of 20 psi (Part B, Section 7.6.1.3). All results were found to provide a large margin of safety over the allowable limits. 
HNF-SD-TP-SARP-023 Rev. 0

\subsubsection{Structural Evaluations and Conclusions}

7.3.5.1 Free Drop. The Doorstop Sample Carrier System drop analysis is evaluated by comparison and analysis to the Sample Pig Transport System. The only difference in the configuration between these two containers is the internals of the DOT 208-L drum. Doorstops as compared to the Pig Shipping Container. The Sample Pig Transport System was dropped from a height of $30 \mathrm{ft}$ in several orientations onto a hard unyielding surface (WHC 1995). After the package was dropped, the Sample Pig Shipping Container was leak tested (WHC 1995) and met the requirements for leaktight given in ANSI 14.5 of $1 \times 10^{-7} \mathrm{std}-\mathrm{cc} / \mathrm{s}$. The Doorstop container is evaluated to be capable of maintaining containment when subjected to the force calculated to be experienced during drop testing. The forces were identified by evaluating the damage observed during testing of the Sample Pig Transport System. That damage was used to back calculate the force that would be experienced by the Doorstop container if the Doorstop Sample Carrier System was subjected to the test. The results of the evaluation support the conclusion that the Doorstop container will maintain containment if subjected to the test.

7.3.5.2 Vibration. The $\mathrm{N}-55$ overpack is certified by the NRC, showing that it will sustain vibration under normal conditions. An evaluation of the screw top lid of the Doorstop container for NCT vibration loading was performed (Part B, Section 7.6.1.6) to demonstrate there is no unwinding of the 1 id or thread fatigue concerns during transport. The evaluation shows that no unwinding of the lid occurs, as demonstrated by the positive torque required for counter rotation of the lid. Also, the evaluation shows that fatigue failure of the lid threads is not a concern due to negligible vibrational stresses imposed on the threads.

7.3.5.3 Compression. The N-55 overpack will support a uniformly distributed load, equal to five times its fully loaded weight, or $1,700 \mathrm{~kg}(3,7501 \mathrm{~b})$, without generating stress in any packaging material in excess of its yield strength (NuPac 1987). Five times the allowable weight of the Doorstop Sample Carrier System is $1621 \mathrm{~kg}(3,575 \mathrm{lb})$. Therefore this requirement is met.

7.3.5.4 Penetration. A $6 \mathrm{~kg}(13 \mathrm{lb})$ rod dropped from a height of $102 \mathrm{~cm}$ (40 in.) has negligible effect on the $\mathrm{N}-55$ overpack (NuPac 1987).

7.3.5.5 Water Spray. The surface of the overpack is galvanized steel and will not be adversely affected by water. There are no places on the overpack where water could collect, freeze, and potentially damage the overpack. The $\mathrm{N}-55$ overpack is certified under the NRC to provide protection for this requirement.

\subsection{ACCIDENT CONDITIONS}

\subsubsection{Conditions to be Evaluated}

HAC per 10 CFR 71 list conditions to be evaluated and their acceptance criteria. For HAC, the evaluation is based on the sequential loading scenarios listed below: 


$$
\text { HNF-SD-TP-SARP-023 ReV. } 0
$$

- Free drop from $9 \mathrm{~m}(30 \mathrm{ft})$ onto an unyielding surface with the cask oriented in such a way as to cause the worst damage.

- Puncture drop of the cask $101 \mathrm{~cm}$ (40 in.) onto a $15.24 \mathrm{~cm}$ (6 in.) diameter bar.

- Exposure of the package to a $801.67^{\circ} \mathrm{C}\left(1475^{\circ} \mathrm{F}\right)$ fire for 30 minutes.

The above loading cases must be applied with the previous evaluated initial condition stresses.

\subsubsection{Acceptance Criteria}

Under the HAC listed above, it must be demonstrated that the Doorstop Sample Carrier System maintains containment and shielding of the samples.

Criteria taken from the NRC Regulatory Guides requires the Doorstop Container stresses not to exceed the allowables in the area of containment closures. Stress allowables used are from ASME BPVC, Section II.

Leak testing after drop testing must meet a leak rate of $1.04 \times 10^{-1} \mathrm{cc} / \mathrm{sec}$, air or less.

\subsubsection{Structural Mode1}

Classical modeling techniques were used for the thread evaluations and the CASKDROP (PacTec) finite element modeling program was used for the g-loading evaluation.

\subsubsection{Initial Conditions}

Initial conditions required for $H A C$ per 10 CFR 71 are identical to those required by NCT.

7.4.4.1 Heat Loading. The heat loading during the impact scenarios also coincides with the NCT. Stresses related to the fire temperature loading on the cask are negligible (Part B, Section 8.0). The fire accident condition temperatures do not affect the material nor add any additional stresses to evaluate.

7.4.4.2 Maximum Pressure Stresses. The maximum pressure stresses are the same as the maximum pressure stresses for NCT.

\subsubsection{Structural Evaluation and Conclusions}

The Doorstop Sample Carrier System has been demonstrated by verification analysis to the Sample Pig Transport System drop testing to maintain containment after $H A C$. 
7.4.5.1 Free Drop. The Doorstop Sample Carrier System drop analysis is performed in Part B, Section 7.6.1.4. The Doorstop container is evaluated to be capable of maintaining containment when subjected to the force calculated to be experienced during drop testing. The forces were identified by evaluating the damage observed during testing of the Sample Pig Transport system. The damage was used to back calculate the force that would be experienced by the Doorstop container if the Doorstop Sample Carrier System was subjected to the test. The results of the evaluation support the conclusion that the Doorstop container will maintain containment if subjected to the test.

7.4.5.2 Crush. Authorized radioactive contents are limited to less than $1000 \mathrm{~A}_{2}$ not as special form radioactive material; therefore, the crush test does not apply.

7.4.5.3 Puncture. The N-55 overpack successfully passed the puncture test when tested by Nuclear Packaging, Inc. for certification of Type B solids (NuPac 1987). Effects to the Doorstop container would be negligible, and less severe than caused by the $9 \mathrm{~m}(30 \mathrm{ft})$ drop.

7.4.5.4 Thermal. The ability of the package to retain its contents and provide adequate shielding through the HAC thermal event is demonstrated in Part B, Section 8.0. The maximum temperature of $122{ }^{\circ} \mathrm{C}\left(251^{\circ} \mathrm{F}\right)$ that the Doorstop container seal reaches occurs after the fire is extinguished. This temperature is lower than the $139^{\circ} \mathrm{C}\left(282{ }^{\circ} \mathrm{F}\right)$ that the Doorstop container seal (containment boundary) reaches during NCT; therefore, the stresses will be less.

7.4.5.5 Immersion - Fissile Material. Authorized contents for the Doorstop Sample Carrier System include only materials exempt from fissile material classification (10 CFR 71.53); therefore, this immersion does not apply.

7.4.5.6 Immersion - Al1 Packages. Water immersion has no effect on the overpack; therefore, it will have no effect on the packaging system (NuPac 1987).

\subsection{REFERENCES}

10 CFR 71, 1995, "Packaging and Transportation of Radioactive Material," Code of Federal Regulations, as amended.

49 CFR 173, 1995, "Transportation," Code of Federal Regulations, as amended.

ANSI, 1987, American National Standard for Radioactive Materials - Leakage Tests on Packages for Shipment, American National Standards Institute, Inc., New York, New York.

ASME, 1995, American Society of Mechanical Engineers Boiler and Pressure Vessel Code, Section II, American Society of Mechanical Engineers, New York, New York. 


$$
\text { HNF-SD-TP-SARP-023 Rev. } 0
$$

NRC, 1987, Certificate of Compliance for the NuPac Mode7 N-55 Overpack, CoC Number 9070, Docket Number 71-9070, U.S. Nuclear Regulatory Commission, Washington, D.C.

NuPac, 1987, Application for NRC Certificate of Compliance Authorizing Shipment of Nuclear Materials in NuPac Model N-55 Packaging, Federal Way, Washington.

WHC-CM-2-14, Hazardous Material Packaging and Shipping, Westinghouse Hanford Company, Richland, Washington. 


$$
\text { HNF-SD-TP-SARP-023 Rev. } 0
$$

\subsection{APPENDICES}

\subsubsection{Design Calculations}

7.6.1.1 Weights and Center of Gravity Calculation. The design weight and vertical center of gravity location of the Doorstop Sample Carrier System are shown below. The Doorstop configuration consists of seven Doorstop packages and their containers placed in a polystyrene spacer assembly. This assembly is contained in the 55-gallon drum which is the inner portion of the N-55 overpack system. Figure B7.6.1.1-1 gives the general arrangement of the package configuration with associated dimensions. Table B7.6.1.1-1 contains detailed weight and dimensional data from which the package center of gravity was calculated. The center of gravity dimension, $Y_{C G}$, becomes:

$$
Y_{\text {CG }}=21.7 \text { in. }
$$

Figure B7.6.1.1-1. Doorstop Container Arrangement.

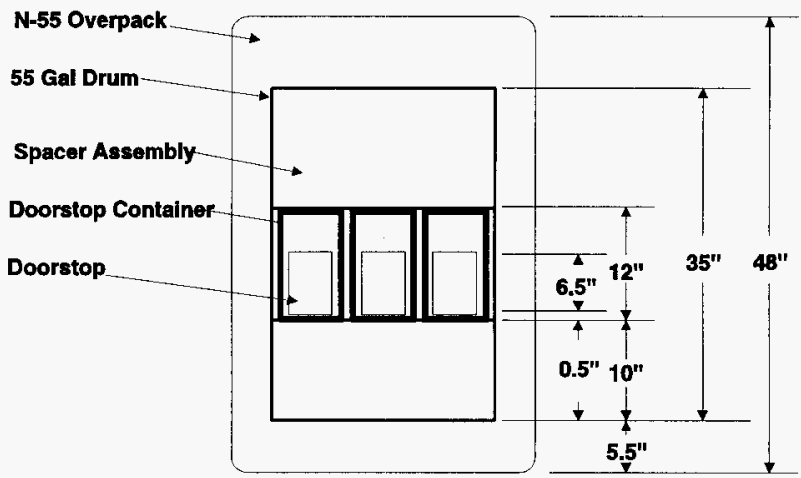

For the loading conditions to be evaluated, the weight of the tiedown frame must also be included in the center of gravity determination, since the acceleration experienced by the $\mathrm{N}-55$ will be experienced by the frame.

The frame is made up of $3 \times 2$ rectangular structural tubing $(0.25$ in. wall thickness) with four $\mathrm{J}$ bolts and four eye bolts attached to the frame ends. Total weight of the tiedown frame is approximately $601 \mathrm{~b}$ with its center of gravity $1.5 \mathrm{in}$. above the bottom of the frame beams. The moment to be added to the above calculations is: 


\section{HNF-SD-TP-SARP-023 Rev. 0}

$(48$ in. +1.5 in. $)(60$ lb $)=2970$ in $-1 b$

The vertical center of gravity dimension, $Y_{c G}$, when the frame is included in the calculation becomes:

$$
Y_{\text {CG }}=23.86 \mathrm{in} \text {. }
$$

Table B7.6.1.1-1. Vertical Center of Gravity Location, Doorstop Sample Carrier System.

\begin{tabular}{|l|c|c|c|}
\hline \multicolumn{1}{|c|}{ Component } & $\begin{array}{c}\text { Weight } \\
\text { (lb) }\end{array}$ & $\begin{array}{c}\text { Distance from } \\
\text { base (in.) }\end{array}$ & Moment \\
\hline \hline N-55 overpack & 200.0 & 24.0 & 4800.0 \\
\hline 17H 55-gallon drum & 55.0 & 23.0 & 1265.0 \\
\hline Spacer assembly & 12.0 & 23.0 & 276.0 \\
\hline Doorstop containers (seven) & 224.0 & 21.8 & 4872.0 \\
\hline Doorstops (seven) & 224.0 & 19.3 & 4312.0 \\
\hline Totals & 715.0 & $\ldots . .-$ & 15525.0 \\
\hline \hline Center of gravity dimension (in.) & & & 21.7 \\
\hline
\end{tabular}


HNF-SD-TP-SARP-023 Rev, 0

7.6.1.2 Lifting Analysis. The N-55 package containing the Doorstop Sample Carrier System is lifted onto its transport vehicle by a lift assembly. The lifting portions of the assembly include the frame and J-bolts which are used to $1 \mathrm{ift}$ the upper half of the overpack. The lifting loads and stresses are determined below.

7.6.1.2.1 Lifting Devices. The tiedown frame can be used to lift the assembled $\mathrm{N}-55$ package when loading or unloading the transport vehicle. The frame is attached to the N-55 lifting lugs by four J-bolts which bolt to the ends of the frame. However, the J-bolts are used only to $1 \mathrm{ift}$ the top of the overpack during loading and unloading operations. The maximum load on each $\mathrm{J}$-bolt is $100 / 2=27.73 \mathrm{~kg}(50 \mathrm{lb})$. A loaded package could be lifted using straight rods with clevis ends in place of the J-bolts. The following analysis shows that the frame assembly is adequate to lift a loaded overpack.

The lifting load is conservatively assumed to be carried by two of the four bolt and clevis assemblies. The load per bolt is then

$$
W_{b}=\frac{800}{2}=181.82 \mathrm{~kg}(400 \mathrm{Ib})
$$

This load is carried through the frame arms to the lifting $U$ bolt welded to the center of the frame.

The lifting induced stresses are calculated below and are to be compared with manufacturer's working load limits for lifting hardware. These are normally $1 / 5$ of breaking loads. For the tiedown frame, the working load limit is considered to be the lesser of $1 / 3$ of material yield stress or $1 / 5$ of material ultimate stress. A Safety Margin, SM, will be calculated to evaluate all stress calculations against the above allowables.

$$
S M=\text { lesser } \text { of }: \frac{0.2 F_{U}}{f} \text { or } \frac{0.33 F_{Y}}{f}
$$

The frame is constructed of $3 \times 2$ structural tubing using A500 Grade B steel. Wall thickness of the tubing is $0.64 \mathrm{~cm}(0.25 \mathrm{in.})$. Material yield stress, $F_{y}$, is $290 \mathrm{MPa}(42,000 \mathrm{psi})$ and ultimate stress, $F_{u}$, is $400 \mathrm{MPa}$ (58,000 psi). A-36 steel is used for other parts of the tiedown assembly. $F_{y}$ is $248 \mathrm{MPa}(36,000 \mathrm{psi})$ and $F_{\mathrm{u}}$ is $400 \mathrm{MPa}(58,000 \mathrm{psi})$.

Based on the loads given above and the loading geometry, the lifting load is considered to be the worst case for the tiedown frame. Lifting anaiyses for individual portions of the tiedown frame are given below.

7.6.1.2.2 J-bolt. The J-bolts are constructed of A-36 $\frac{1}{2}$ in. diameter rod. The $\mathrm{J}$ bend at the end of the bolt has an inside radius of $\frac{1}{2}$ in. The load per rod, $W_{R}$, is assumed to be a maximum of $23 \mathrm{~kg}(50 \mathrm{lb})$ as shown above. The J-bolts are not used to lift a loaded overpack. Calculating the tensile stress in the bolt, the minimum tensile area of the bolt is $0.9155 \mathrm{~cm}^{2}$ $\left(0.1419 \mathrm{in}^{2}\right)$ at the threaded portion of the bolt ( $\frac{1}{2}$ in.-13UNC) 


$$
\text { HNF-SD-TP-SARP-023 Rev. } 0
$$

$$
\begin{aligned}
& E_{t}=\frac{W_{R}}{A}=\frac{50}{0.1419}=2.4 \mathrm{MPa}(352 \mathrm{psi}) \\
& S M=\frac{11,600}{352}=16.46
\end{aligned}
$$

NOTE: The straight bolt which could replace the J-bolt for lifting the loaded assembly would be the same diameter as the J-bolt. Since it would experience a $182 \mathrm{~kg}(400 \mathrm{lb})$ load rather than a $23 \mathrm{~kg}$ (50 1b) load, its Safety Margin would be $1 / 8$ that of the J-bolt or 2.06 .

The $\mathrm{N}-55$ lifting lug is assumed to load the rod at the center of the curved portion of the "J." This results in a moment which can be assumed constant along the length of the bolt including the threaded portion (if any) below the nut and washer on the top surface of the frame. This is because the bolt hangs from the nut and passes through a hole in the lower frame which is considerably larger than the bolt diameter. The moment arm from the center of the lifting lug to the centerline of the bolt is

$$
L_{m}=0.5+\frac{0.5}{2}=1.9 \mathrm{~cm}(0.75 \mathrm{in.})
$$

The section modulus of the bolt at the threaded area is

$$
S=\frac{\pi d^{3}}{32}=\frac{\pi(0.425)^{3}}{32}=0.123 \mathrm{~cm}^{3}\left(0.0075 \mathrm{in}^{3}\right)
$$

where $d$ is based on the tensile area given above.

The bending stress becomes:

$$
S_{b}=\frac{M_{b}}{S}=\frac{50(0.75)}{0.0075}=34 \mathrm{MPa}(5,000 \mathrm{psi})
$$

Combining the tensile stress with the tensile portion of the bending stress results in a total tensile stress of:

$$
e S_{T}=S_{t}+S_{b}=352+5,000=36 \mathrm{MPa}(5,352 \mathrm{psi})
$$

If the moment can be shown not to reach the threaded portion of the bolt, the highest stress area of the bolt is at the transition from the curved " $J$ " to the straight shank of the bolt. The tensile area of the bolt at this location is $2.74 \mathrm{~cm}^{2}\left(0.425 \mathrm{in}^{2}\right)$ giving a tensile stress of:

$$
f_{t}=\frac{W_{R}}{A}=\frac{50}{0.1963}=1.8 \mathrm{MPa}(255 \mathrm{psi})
$$


Conservatively using a correction factor for curved beams from Formulas for Stress and Strain (Roark and Young 1975), Table 16, Case 2 with $R / C=$ $0.75 / 0.25=3.0, k_{i}=1.332$ the bending stress becomes:

$$
S_{b}=k_{i} \frac{M_{b}}{S}=1.332 \frac{50(0.75)}{0.0123}=28 \mathrm{MPa}(4,061 \mathrm{psi})
$$

Combining the tensile stress with the tensile portion of the bending stress results in a total tensile stress of:

$$
S_{T}=S_{t}+S_{b}=255+4,061=30 \mathrm{MPa}(4,316 \mathrm{psi})
$$

Minimum Safety Margin from the two calculations shown above:

$$
S M=\frac{\frac{58,000}{5}}{5,352}=2.17
$$

Therefore, the $\mathrm{J}$-Bolts meet $1 / 5$ of $S_{u}$ by having a positive safety margin.

The J-Bolts are also evaluated as shown in Section 7.6.1.2.7 to meet the Hanford Site Hoisting and Rigging Manual (RL 1993).

7.6.1.2.3 Frame. The lifting load is carried from the frame ends where the bolts attach to the center lifting bail as shown in Figure B7.6.1.2-1 below. The maximum moment in the frame is:

$$
M_{F}=W_{R} I_{f}=400(16.5)=746 N-m(6,600 i n-1 b)
$$

The structural tubing has a section modulus, $S_{x}$, of $9.48 \mathrm{~cm}^{3}\left(1.47 \mathrm{in}^{3}\right)$. The maximum bending stress is then:

$$
\begin{aligned}
& f_{b}=\frac{M_{F}}{S_{Y}}=\frac{6,600}{1.47}=31 \mathrm{MPa}(4,490 \mathrm{psi}) \\
& S M=\frac{11,600}{4,490}=2.58
\end{aligned}
$$

Therefore, the frame meets $1 / 5 \mathrm{~S}_{\mathrm{u}}$ by having a positive safety margin.

7.6.1.2.4. Lifting Bail. The lifting bail is a U-bolt constructed of $3 / 4$ in. rod with an inside diameter of $2 \mathrm{in}$. The radius of the centerline of the bail, $R$, is then $1.375 \mathrm{in}$. The U-bolt material is A-36 steel. 


\section{Figure B7.6.1.2-1. Tiedown Frame.}

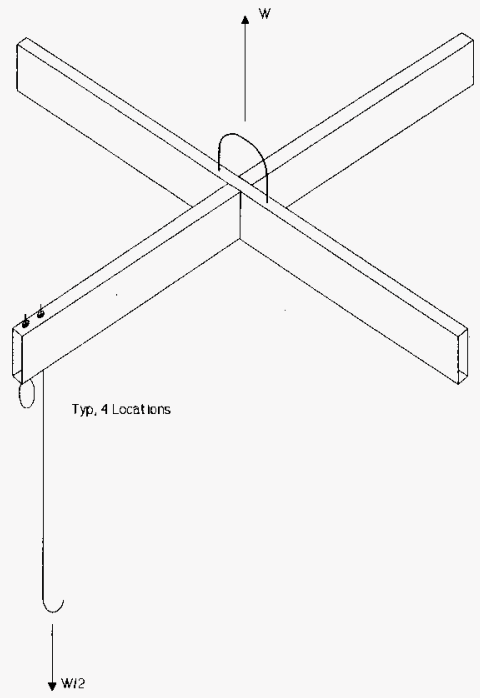

The U-bolt can be considered as $\frac{1}{2}$ of a chain link with a central stud joining the two sides of the link. This configuration is analyzed by Practical Stress Analysis in Engineering Design (Blake 1960). The maximum bending moment occurs at the point of loading.

$$
M_{0}=\frac{W R C_{1}}{2}
$$

Where $C_{1}$ is a function of the ratio $L / R$.

$$
C_{1}=\frac{(k+2)\left[k^{3}+6 k^{2}+12 k(4-\pi)+48(\pi-3)\right]}{k^{4}+4 \pi k^{3}+48 k^{2}+24 \pi k+24\left(\pi^{2}-8\right)}
$$

where $k=L / R$.

Substituting $k=2.5 / 1.375=1.818$ gives $C_{1}=0.459$ and thus the maximum moment becomes: 


$$
\begin{array}{r}
\text { HNF-SD-TP-SARP-023 Rev. } 0 \\
M_{0}=\frac{800(1.375)(0.459)}{2}=28.5 \mathrm{~N}-\mathrm{m}(252.5 \mathrm{in}-1 \mathrm{~b})
\end{array}
$$

Similarly, a tensile load, $H$, is produced at the point of loading

$$
H=\frac{W C_{2}}{2}
$$

where $C_{2}$ is given by:

$$
C_{2}=\frac{12(k+2)[(\pi-2) k+2(4-\pi)]}{k^{4}+4 \pi k^{3}+48 k^{2}+24 \pi k+24\left(\pi^{2}-8\right)}
$$

Substituting gives $C_{2}=0.407$ and the tensile load becomes:

$$
H=\frac{800(0.407)}{2}=724 N(162.81 \mathrm{~b})
$$

At the point of loading, on the outer surface the maximum tensile stress is due to both the tensile loading, $H$, and the moment, $M_{0}$. The stress due to $\mathrm{H}$ is:

$$
S_{t}=\frac{H}{A}=\frac{162.8}{0.442}=2.5 \mathrm{MPa}(368.5 \mathrm{psi})
$$

The bending stress can be calculated for a curved beam using Formulas for Stress and Strain (Roark and Young 1975) Table 16, Case 2 with R/c $=3.67$. The correction factor for the inner surface is by interpolation, $k_{i}=1.24$. The section modulus of the bail is:

$$
S_{x}=\frac{\pi d^{3}}{32}=0.678 \mathrm{~cm}^{3}\left(0.0414 \mathrm{in}^{3}\right)
$$

The bending stress on the inner surface of bail (compressive) is:

$$
f_{b}=k_{i} \frac{M_{b}}{S}=1.24 \frac{252.5}{0.0414}=52 \mathrm{MPa}(7,560 \mathrm{psi})
$$

The sum of the tensile stress and the compressive bending stress is:

$$
S_{T}=S_{t}+S_{b}=369+-7,560=-49.6 \mathrm{MPa}(-7,191 \mathrm{psi})
$$


The tensile stress in one of the bail legs is:

$$
f_{t}=\frac{\left(0.5 W_{b}\right)}{A_{W}}=\frac{400}{\pi(0.375)^{2}}=6.2 \mathrm{MPa}(905 \mathrm{psi})
$$

The maximum moment in the bail 1 eg is at the frame connection and can be calculated using Equation 29.11b of Practical Stress Analysis in Engineering Design (Blake 1960).

$$
M=M_{0}-\frac{W R}{2}+H(R+x)=252.5-\frac{800(1.375)}{2}+162.8(1.375+1.25)=15 N-m(:
$$

Bending stress is:

$$
f_{b}=\frac{M_{b}}{S}=\frac{130}{0.0414}=21.6 \mathrm{MPa}(3,136 \mathrm{psi})
$$

Combining the tensile portion of the bending stress and the stress due to the tensile load:

$$
f_{b}+f_{t}=3,136+905=28 \mathrm{MPa}(4,041 \mathrm{psi})
$$

From above the maximum stress in the bail occurs at the point of loading. The Safety Margin is:

$$
S M=\frac{\frac{58,000}{5}}{7,191}=1.61
$$

Therefore, the bail meets the requirements.

7.6.1.2.5 Frame Welds. Two opposing frame arms are welded to the tube section which forms the other two arms. The attaching welds are continued completely around the attaching tube section. Assume the weld forms a $5.0 \mathrm{~cm}$ $x 7.6 \mathrm{~cm}$ (2 in. $\times 3$ in.) box section with a wall thickness of $0.48 \mathrm{~cm}$ (3/16 in.). Treating the weld as a line the effective section modulus of the weld is:

$$
S_{w}=b d+\frac{d^{2}}{3}=(2.1875)(2.8125)+\frac{(2.8125)^{2}}{3}=56.7 \mathrm{~cm}^{2}\left(8.789 \mathrm{in}^{2}\right)
$$

where $b$ and $d$ are the width and height of the section at the centerline of the weld line. The effective shear area of the weld is:

$$
A_{w}=2 b d=2(2.1875)(2.8125)=61.74 \mathrm{~cm}^{2}\left(9.57 \mathrm{in}^{2}\right)
$$


Using a bending moment of $746 \mathrm{~N}-\mathrm{m}(6,600 \mathrm{in}-1 \mathrm{~b})$ and a shear load of $1,779 \mathrm{~N}$ (400 1b), the weld loading becomes:

$$
f_{W}=\left[\left(\frac{400}{9.57}\right)^{2}+\left(\frac{6.600}{8.789}\right)^{2}\right]^{0.5}=132 \mathrm{kN} / \mathrm{m}(752 \mathrm{lb} / \mathrm{in})
$$

The allowable weld load for a $0.48 \mathrm{~cm}(3 / 16 \mathrm{in.})$ weld is:

$$
\begin{aligned}
& \tau_{w}=(0.6)(0.1875)(.707)\left(\frac{58,000}{5}\right)=161 \mathrm{kN} / \mathrm{m}(923 \mathrm{Ib} / \mathrm{in}) \\
& S M=\frac{923}{752}=1.23
\end{aligned}
$$

The lifting bail is welded to the top surface of the frame using to $0.64 \mathrm{~cm}$ (1/4 in.) fillet welds around the base of each leg of the bail. The bail is constructed of $1.9 \mathrm{~cm}$ (3/4 in.) A-36 rod. The weld length around one of the legs is:

$$
I_{w}=0.75 \pi=6 \mathrm{~cm}(2.36 \mathrm{in.})
$$

The weld load is:

$$
f_{w}=\frac{0.5 W_{b}}{l_{w}}=\frac{430}{2.36}=32 \mathrm{kN} / \mathrm{m}(182.21 \mathrm{~b} / \mathrm{in})
$$

The allowable weld load is:

$$
\begin{aligned}
& \tau_{w}=(0.6)(0.25)(0.707)\left(\frac{58,000}{5}\right)=215 \mathrm{kN} / \mathrm{m}(1,230 \mathrm{lb} / \mathrm{in}) \\
& S M=\frac{1,230}{182.2}=6.75
\end{aligned}
$$

\subsection{References.}

Blake, Alexander, 1960, Practical Stress Analysis in Engineering Design, Second Edition, Marcel Dekker, Inc., New York, New York.

RL, 1993, Hanford Site Hoisting and Rigging Manua7, DOE-RL-92-36, U.S. Department of Energy, Richland Operations Office, Richland, Washington.

Roark, R. J., and W. C. Young, 1975, Formulas for Stress and Strain, Fifth Edition, McGraw Hill Book Company, New York, New York. 
HNF-SD-TP-SARP-023 ReV. 0

\subsubsection{Reduced and Increased External Pressure Evaluation.}

ENGINEERING SAFETY EVALUATION

Subject: Reduced and Increased External Egessure Evaluation-Doorstop Container _Page: 1 of 10

Originator: S. S. Shiraga Date:01/16/97

Checker: R. J.Smith Date:01/23/97

I. Objective:

The objective of this evaluation is to evaluate the Doorstop Containers for reduced and increased external pressurization for the nomal transport conditions (NTC).

\section{References:}

ASME, Boiler and Pressure Vessel Code, Section III, Appendices, American Society of Mechanical Engineers, New York, New York, 1992.

ASME, Boiler and Pressure Vessel Code, Section II, Part D, American Society of Mechanical Engineers, New York, New York, 1995.

RHO, Drawing No. H-2-73008, Rev 2, Door Stop Container, Rockwell Hanford Operations, Richland, Washington, 1978.

\section{Results and Conclusions:}

The analysis evaluates the doorstop container as a cylindrical shell with flat head closure ends. The stresses due to pressure at the joints for the shell to the flat heads are evaluated in accordance with ASME Section JII, Appendices, Articles A-2000, A-5000, and A-6000. The container is conservatively evaluated as a smooth bore cylinder, the additional material of the closure lid is ignored.

As demonstrated by the evaluation, the stresses from the worst case of reduced extemal pressure are insignificant. The case of increased external pressure is not evaluated since the pressure is much lower and for cylindrical shells extemal and internal pressures are evaluated in the same manner. Therefore, the Doorstop Container withstands the affects of both reduced and increased extemal pressures. 
Subject:_Reduced and lncreased External Pressure Evaluation-Doorstop Container

\section{Evaluation:}

Doorstop Container NTC Pressure Evaluation:

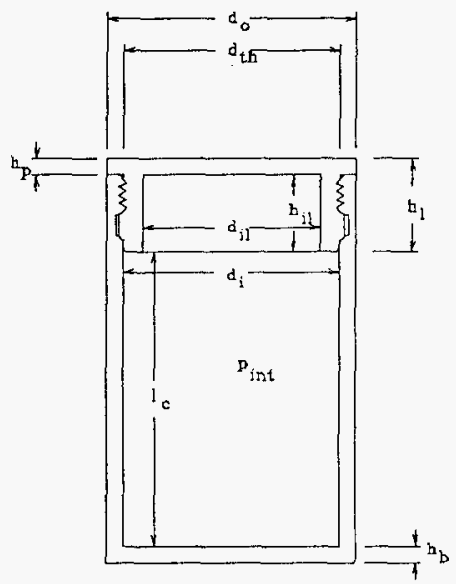

Nominal dimensions (RHO 1978):

Outside diameter of shefl:

$$
d_{0}=6.38 \mathrm{in}
$$

Inside diameter of shell:

$$
\mathrm{d}_{\mathrm{i}}=5.50 \mathrm{in}
$$

Wall thickness of shell:

$$
r_{w}:=\frac{d_{o}-d_{i}}{2} \quad t_{w}=0.44 \cdot i n
$$

Outside radius of shell:

$$
r_{0}:=\frac{d_{0}}{2} . \quad r_{0}=3.19 \cdot \text { in }
$$

Inside radius of shell:

$$
r_{i}:=\frac{d_{i}}{2} \quad \quad r_{i}=2.75 \cdot \mathrm{in}
$$

Height of lid: $\quad h_{1}:=1.5$ in Thickness of bottom plate: $\quad h_{b}=0.5$ in

Thickness of top plate: $\quad h_{p}=h_{1}-(0.817+0.38)$-in $\quad h_{p}=0.3 \cdot$ in

Inside diameter of tid: $\quad d_{i l}:=5.12$ in inside length of shetl: $\quad t_{c}:=(9.88-1.004) \cdot$ in $\quad l_{c}=8.88 \cdot$ in

Ambient pressure differentials specified in 10 CFR 71 :

Reduced external pressure: $\quad P_{\text {tep }}=3.5-\mathrm{psi} \quad$ Increased extemal pressure: $\quad P_{\text {iep }}=20$-psi

Worst case NCT internal temperature in ${ }^{\circ} \mathrm{F}$ (Part B, Section 8.0), assumed as operating: $\quad t_{\text {in }}=282$

Pressure from gas generation (Part B, Section 3): $\quad p_{\text {gas }}:=4.24 \mathrm{psi}$

Assumed atmospheric temperature and pressure at loading: $\quad t_{\mathrm{atm}}=70 \quad \mathrm{P}$ atm $:=1 \cdot \mathrm{atm}$ 
HNF-SD-TP-SARP-023 ReV. 0

\section{ENGINEERING SAFETY EVALUATION}

Subject: Reduced and Increased External Pressure Evaluation-Doorstop Container

Originator: S. S. Shiraga

Checker: R, J.Smith

RTS

Page: 3 of 10

Date: $01 / 16 / 97$

Date: $01 / 23 / 97$

Internal pressurc inside container at operating temperature and pressure:

$$
P_{\text {int }}:=\left(\frac{t_{\text {in }}+460}{t_{\text {atm }}+460}\right) \cdot\left(P_{\text {atm }}+p_{\text {gas }}\right) \quad P_{\text {int }}=26.51 \cdot p s i
$$

Differential pressures:

Reduced external pressure: $\quad \Delta \mathrm{p}_{\text {rex }}:=\mathrm{p}_{\text {int }}-\mathrm{p}_{\text {rep }} \quad \Delta \mathrm{p}_{\text {rex }}=23.01 \cdot \mathrm{psi}$

Increased external pressure: $\quad \Delta p_{\text {iex }}=p_{\text {int }}-p_{\text {iep }} \quad \Delta p_{\text {iex }}=6.51 \cdot p s i$

Since reduced external pressure results in largest differential, evaluate for reduced external pressure.

Idealize as cylinderical shell with closed ends under intemal pressure.

Doorstop Container Material properties for ASTM A-312, 304L stainiess steel (ASME Section Il, Part D, VIII-1) at $300 \mathrm{~F}$ :

RT yield strength (page 95): $\quad \mathrm{s}_{\mathrm{y}}:=25 \mathrm{ksi} \quad$ RT ultimate strength (page 95): $\quad s_{u}:=70 \mathrm{ksi}$

Allowable membrane stress (page 96): $\quad s_{\mathrm{m}}=15.3 \mathrm{ksi} \quad$ Poisson's ratio: $\quad v_{\text {sst }}:=0.29$

Elastic modulus (614): $\quad E_{s s t}:=27 \cdot 10^{6} \cdot \mathrm{psi}$

Defermine stresses in the shell away from discontinuities (ASME Section III, Article-2000, page 462):

Ratio of outside radius to inside radius: $Y:=\frac{r_{0}}{r_{i}} \quad$ Mean radius of shell: $\quad r_{m}=r_{i}+\frac{1}{2} \cdot t w$

Ratio of outside radius to intermediate radius: $\quad z=\frac{r_{0}}{r_{m}}$

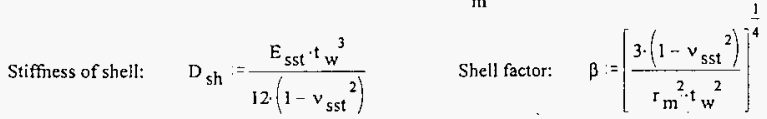

Principle stresses in shell:
Hoop:
$\sigma_{\mathrm{st}}:=\Delta \mathrm{p}_{\mathrm{rex}} \frac{1+\mathrm{Z}^{2}}{\mathrm{Y}^{2}-1}$
$\sigma_{\text {st }}=143 \cdot \mathrm{psi}$
Longitudinal: $\quad \sigma_{\mathrm{sl}}=\frac{\Delta \mathbf{p}_{\text {rex }}}{Y^{2}-1}$
$\sigma_{\mathrm{s} l}=67^{\circ} \mathrm{psi}$ 
HNF-SD-TP-SARP-023 Rev. 0

ENGINEERING SAFETY EVALUATION

Subject: Reduced and Increased External Pressure Evaluation- Doorstop Container _._Page: 4 of 10

Originator: S.S. Shiraga D.Date:01/16/97

RJS

Date:01/23/97

Radial: $\quad \sigma_{\mathrm{sr}}=\Delta \mathrm{p}_{\mathrm{rex}} \cdot \frac{1-\mathrm{Z}^{2}}{\mathrm{Y}^{2}-1} \quad \sigma_{\mathrm{sr}}=-10 \cdot \mathrm{psi}$

General primary membrane stress intensity: $\quad \sigma_{\mathrm{spr}}=\left(\frac{\Delta \mathrm{p}_{\mathrm{rex}^{-\mathrm{r}} \mathrm{i}}}{\mathrm{t}_{\mathrm{w}}}\right)+\frac{\Delta \mathrm{p}_{\mathrm{rex}}}{2} \quad \sigma_{\mathrm{spr}}=155^{\circ} \mathrm{psi}$

Primary plus secondary: $\quad \sigma_{\text {sps }}=\frac{2 \cdot \Delta \mathrm{p}_{\text {rex }} \cdot Y^{2}}{Y^{2}-1} \quad \sigma_{\text {sps }}=179 \cdot \mathrm{psi}$

Margins of Safety on Shell:

Primary membrane: $\quad \mathrm{MS}_{\mathrm{shp}}:=\frac{\mathrm{s}_{\mathrm{m}}}{\sigma_{\mathrm{spr}}}-1 \quad \mathrm{MS}_{\mathrm{shp}}=97.5$

Primary plus secondary: $\quad$ MS $S_{\text {shs }}:=\frac{3 \cdot \mathrm{s} m}{\sigma_{\mathrm{sps}}}-1 \quad \mathrm{MS}_{\mathrm{shs}}=255.16$

Determine discontinuity stresses at ends ASME Section III, Appendix, Article A-6000:

Shell characteristic length: $\quad \frac{3}{\beta}=2.66 *$ in $\quad$ Since this is less than $I_{c}$
$B_{11}:=1$
$\mathrm{B}_{12}:=1$
$\mathrm{B}_{22}:=1$
$\mathrm{G}_{11}=0$
$\mathrm{G}_{12}=0 \quad \mathrm{G}_{22}:=0$

For simplicity and conservatism, idealize as a long shell of uniform thickness, with two different closed ends.

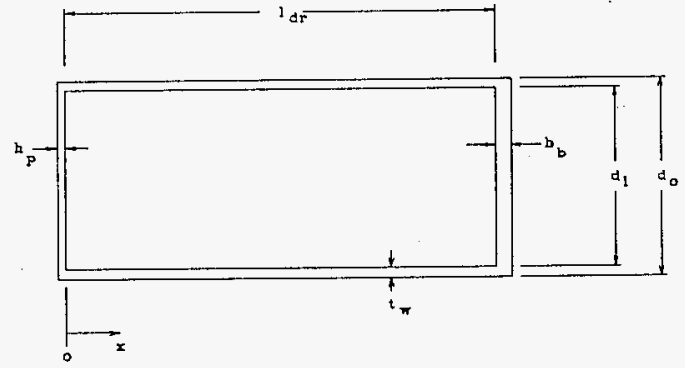


Total intemal length: $\quad 1_{\mathrm{dr}}=9.88 \mathrm{in}$

Radial displacement and rotation at 0 , top end plate:

Top plate geometric constants ASME Section III, Appendix, Article A-5000:

Plate factor: $\quad f_{t p}=\frac{h_{p}}{r_{0}}$

$F_{t 1}=\frac{3 \cdot\left(1-v_{s s t}\right) \cdot\left(2-f_{t p}{ }^{2}\right) \cdot\left(1-f_{t p}\right)^{2} \cdot\left[8-f_{t p} \cdot\left(4-f_{t p}\right) \cdot\left(1-v_{s s t}\right)\right]}{16\left(2-f_{t p}\right)}$

$F_{t 2}:=\frac{3}{8} \cdot\left(1-f_{t p}\right)^{2} \cdot\left[\left(1-v_{s s t}\right) \cdot\left(2-f_{t p}^{2}\right)+4 \cdot\left(1+v_{s s t}\right) \cdot\left(1+2 \cdot \ln \left(\frac{2-f_{t p}}{2-2 \cdot f_{t p}}\right)\right)\right]$

$F_{13}=\frac{3}{8} \cdot\left(1-v_{s s t}\right) \cdot\left(2-f_{t p}\right) \cdot\left[8-f_{t p} \cdot\left(4-f_{t p}\right) \cdot\left(1-v_{s s t}\right)\right]$

$F_{14}:=\frac{1}{8} \cdot\left[8-f_{t p} \cdot\left(4-f_{t p}\right) \cdot\left(1-v_{s s t}\right)\right]$

$$
\begin{aligned}
& \text { Rotation due to pressure of the top plate: } \left.\quad \theta_{\mathrm{tpp}}:=\frac{\mathrm{F}_{\mathrm{t} 1}}{\mathrm{E}_{\mathrm{sst}} \cdot\left(\frac{\mathrm{h}}{\mathrm{r}_{\mathrm{m}}}\right)^{3}} \cdot \Delta_{\mathrm{p}}\right)_{\mathrm{rex}} \\
& \text { Displacement due to pressure of the top plate: } \quad \delta_{\mathrm{tpp}}=-\left(\frac{\mathrm{h} p}{2}\right) \cdot \theta_{\mathrm{tpp}}
\end{aligned}
$$

Radial displacement and rotation at $L$, bottom end plate:

Bottom plate geometric constants ASME Section III, Appendix, Article A-5000:

Plate factor: $\quad f_{b p}: \frac{h_{b}}{r_{0}}$

$F_{b 1}=\frac{3 \cdot\left(1-v_{s s t}\right) \cdot\left(2-f_{b p}{ }^{2}\right) \cdot\left(1-f_{b p}\right)^{2} \cdot\left[8-f_{b p} \cdot\left(4-f_{b p}\right) \cdot\left(1-v_{s s t}\right)\right]}{16\left(2-f_{b p}\right)}$

$F_{b 2}=\frac{3}{8} \cdot\left(1-f_{b p}\right)^{2} \cdot\left(\left(1-v_{s s t}\right) \cdot\left(2-f_{b p}{ }^{2}\right)+4 \cdot\left(1+v_{s s t}\right) \cdot\left(1+2 \cdot \ln \left(\frac{2-f_{b p}}{2-2 \cdot f_{b p}}\right)\right]\right.$ 
HNF-SD-TP-SARP-023 ReV. 0

\section{ENGINEERING SAFETY EVALUATION}

Subject: Reduced and Increased External Pressure Evaluation-Doorstop Container Originator: $\_$. S. Shiraga

Checker:

Page: 6 of 10

Date: $01 / 16 / 97$

Date: $01 / 23 / 97$

$F_{b 3}=\frac{3}{8} \cdot\left(1-v_{s s t}\right) \cdot\left(2-f_{b p}\right) \cdot\left[8-f_{b p} \cdot\left(4-f_{b p}\right) \cdot\left(1-v_{s s t}\right)\right]$

$F_{b 4}:=\frac{1}{8} \cdot\left[8-f_{b p} \cdot\left(4-f_{b p}\right) \cdot\left(I-v_{s s t}\right)\right]$

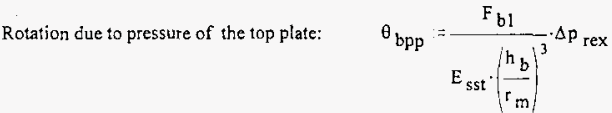

Radial displacement due to pressure of the top plate:

$\delta_{\text {bpp }}=-\left(\frac{h_{b}}{2}\right) \cdot \theta_{b p p}$

Radial displacement and rotation of shell, by symmetry the same at both ends:

Rotation due to pressure on shelf: $\quad \theta_{\text {sh }}=0$

Radial displacement due to pressure on shell:

$$
\delta_{s h}=\Delta p_{r e x}\left[\frac{r_{i}^{2}}{E_{s s t} \cdot\left(r_{0}^{2}-r_{i}^{2}\right) \cdot r_{m}}\right] \cdot\left[r_{m}^{2} \cdot\left(I-2 \cdot v_{s s t}\right)+s_{0}^{2} \cdot\left(1+v_{s s t}\right)\right] \quad \delta_{s h}=0 \cdot \text { in }
$$

Equate the total rotations and radial displacements at each junction and solve for moments and shear forces:

Given

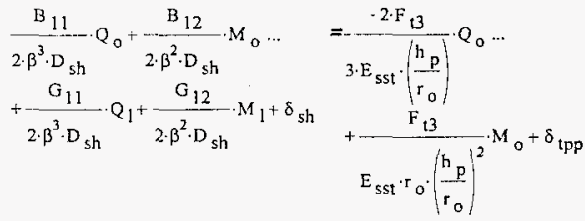


HNF-SD-TP-SARP-023 ReV. 0

ENGINEERING SAFETY EVALUATION

Subject: Reduced and Increased Extemal Pressuje Evaluation-Doorstop Container Originator: S. S. Shiraga

Checker: R.J. Smith

$\left[\begin{array}{c}\frac{{ }^{B} 12}{2 \cdot \beta^{2} \cdot D_{s h}} \cdot Q_{0}+\frac{B_{22}}{\beta \cdot D_{s h}} \cdot M_{0} \ldots \\ +\frac{G_{12}}{2 \cdot \beta^{2} \cdot D_{s h}} \cdot Q_{1}+\frac{G_{22}}{2 \cdot \beta \cdot D_{s h}} \cdot M_{1}\end{array}\right]+\theta_{s h}=\frac{F_{t 3}}{E_{s s t} \cdot r_{i} \cdot\left(\frac{h}{r_{0}}\right)^{2}} \cdot Q_{0}-\frac{2 \cdot F_{t 3}}{E_{s s t} \cdot r_{0}^{2} \cdot\left(\frac{h_{p}}{r_{0}}\right)^{3}} \cdot M_{0} \cdots$

$\begin{array}{ll}\frac{G_{11}}{2 \cdot \beta^{3} \cdot D_{s h}} \cdot Q_{0}+\frac{G_{12}}{2 \cdot \beta^{2} \cdot D_{s h}} \cdot M_{0} \ldots & =\frac{-2 \cdot F_{b 3}}{3 \cdot E_{s s t} \cdot\left(\frac{h_{b}}{r_{0}}\right)^{Q_{1}} \cdot .} \\ +\frac{B_{11}}{2 \cdot \beta^{3} \cdot D_{s h}} \cdot Q_{1}+\frac{B_{12}}{2 \cdot \beta^{2} \cdot D_{s h}} \cdot M_{1}+\delta_{s h} & +\frac{F_{b 3}}{E_{s s t} \cdot r_{0} \cdot\left(\frac{h_{b}}{r_{0}}\right)^{2}} \cdot M_{1}+\delta_{b p p}\end{array}$

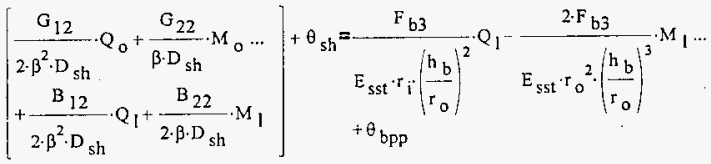

Solve simultaneous linear equations:

$$
Q_{0}=-24 \cdot \frac{\mathrm{lbf}}{\text { in }} \quad \mathrm{M}_{0}=18 \cdot \mathrm{lbf} \quad \mathrm{Q}_{1}=-22 \cdot \frac{\mathrm{lbf}}{\mathrm{in}} \quad \mathrm{M}_{1}=15 \cdot \mathrm{ibf}
$$

Determine discontinuity stresses in top plate junction $(O)$ :

Total displacement at junction O inside surface ASME 1995, Article A-2243:

$$
\delta_{s 0}:=\frac{B_{11}}{2 \cdot \beta^{3} \cdot D_{s h}} \cdot Q_{0}+\frac{B_{12}}{2 \cdot \beta^{2} \cdot D_{s h}} \cdot M_{0}+\frac{G_{11}}{2 \cdot \beta^{3} \cdot D_{s h}} \cdot Q_{1}+\frac{G_{12}}{2 \cdot \beta^{2} \cdot D_{s h}} \cdot M_{1} \quad \delta_{s o}=-6.0710^{-6} \cdot \text { in }
$$

Secondary hoop stress: $\quad \sigma_{\text {soh }}=\frac{E_{s s t} \cdot \delta_{s o}}{r_{m}}+\frac{6 \cdot v_{s s t} \cdot M_{0}}{t_{w}{ }^{2}} \quad \sigma_{s o h}=106 \cdot p s i$

Secondary longitudinal stress: $\quad \sigma_{\text {slo }}=\frac{6 \cdot \mathrm{M}_{\mathrm{o}}}{\mathrm{t}_{\mathrm{w}}{ }^{2}} \quad \sigma_{\mathrm{slo}}=557 \cdot \mathrm{psi}$ 
HNF-SD-TP-SARP-023 Rev. 0

\section{ENGINEERING SAFETY EVALUATION}

Subject: Reduced and Increased External Pressure Evaluation-Doorstop Container Originator: S. S. Shiraga Checker: R. J. Smith

Secondary radial stress: $\quad \cdot \sigma_{\text {sro }}=0$-psi

Determine secondary stress intensities at junction $O$ :

$$
\begin{array}{ll}
s_{1 t s}=\left|\sigma_{\text {soh }}-\sigma_{\text {slo }}\right| & s_{\text {Its }}=451 \cdot \mathrm{psi} \\
s_{2 t s}:=\left|\sigma_{\text {slo }}-\sigma_{\text {sro }}\right| & s_{2 t s}=557 \% \mathrm{psi} \\
s_{3 t s}=\left|\sigma_{\text {sro }}-\sigma_{\text {soh }}\right| & s_{3 t s}=106 \% \mathrm{psi}
\end{array}
$$

Margin of Safety at junction L: $\quad M S_{s t p}=\frac{3.5 m}{\sigma_{s p s}+s_{2 t s}}-1 \quad M_{s t p}=61.35$

Determine discontinuity stresses in botton plate junction (L):

Total displacement at junction $\mathrm{L}$ inside surface:

$$
\delta_{s !}:=\frac{G_{11}}{2 \cdot \beta^{3} \cdot D_{s h}} \cdot Q_{0}+\frac{G_{12}}{2 \cdot \beta^{2} \cdot D_{s h}} \cdot M_{0}+\frac{B_{11}}{2 \cdot \beta^{3} \cdot D_{s h}} \cdot Q_{1}+\frac{B_{12}}{2 \cdot \beta^{2} \cdot D_{s h}} \cdot M_{1} \quad \delta_{s 1}=-9.59 \cdot 10^{-6} \cdot \text { in }
$$

Secondary hoop stress: $\quad \sigma_{s l h}=\frac{E_{s s t} \cdot \delta_{s l}}{r_{m}}+\frac{6 \cdot v_{s s t} \cdot M_{l}}{t_{w}{ }^{2}} \quad \sigma_{s l h}=44 \cdot p s i$

Secondary longitudinal stress: $\quad \sigma_{\mathrm{sll}}=\frac{6 \mathrm{M}_{\mathrm{l}}}{\mathrm{t}_{\mathrm{w}}{ }^{2}} \quad \sigma_{\mathrm{sll}}=453 \cdot \mathrm{psi}$

Secondary radial stress: $\quad \sigma_{\text {srl }}:=0 \cdot \mathrm{psi}$

Determine secondary stress intensities at junction L:

$$
\begin{array}{ll}
s_{1 b s}:=\left|\sigma_{s l h}-\sigma_{s l l}\right| & s_{1 b s}=409 \cdot p s i \\
s_{2 b s}=\left|\sigma_{s l l}-\sigma_{s r l}\right| & s_{2 b s}=453 \cdot p s i \\
s_{3 b s}=\left|\sigma_{s t l}-\sigma_{s l h}\right| & s_{3 b s}=44 \cdot p s i
\end{array}
$$

Margin of Safety at junction $L: \quad M S_{s b p}=\frac{3 \cdot s_{m}}{\sigma_{s p s}+s_{2 b s}}-1 \quad M_{s b p}=71.56$ 
HNF-SD-TP-SARP-023 Rev. 0

ENGINEERING SAFETY EVALUATION

Subject: Reduced and Increased Extemal Pressure Evaluation-Doorstop Container

Page: 9 of 10

Checker: R. J. Smith

Date: $\underline{01 / 23 / 97}$

Determine stresses in top and bottom closure plates ASME Section III, Appendix, Article A-5000:

Assuming the plate is simply supported the maximum primary stresses occur at the center.

Top Plate inside surface: $\quad x_{p}:=\frac{h_{p}}{2}$

Radial stress from pressure:

Radial stress from edge loads:

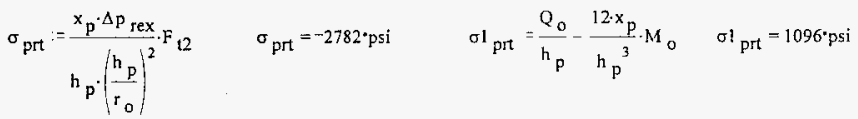

Hoop stress from pressure:

Hoop stress from edge loads:

$$
\sigma_{p h t}=\frac{x_{p} \cdot \Delta p_{r e x}}{h_{p} \cdot\left(\frac{h p}{r_{o}}\right)^{2}} F_{t 2} \quad \sigma_{p h t}=-2782 \cdot p s i \quad \quad \sigma_{p h t}=\frac{Q_{o}}{h_{p}}-\frac{12 \cdot x_{p}}{h_{p}{ }^{3}} \cdot M_{o} \quad \sigma l_{p h t}=1096 \cdot p s i
$$

Longitudinal stress from pressure:

$$
\sigma_{p l t}:=\frac{\Delta p_{r e x}}{h_{p}} \cdot\left(x_{p}-\frac{h_{p}}{2}\right) \quad \sigma_{p l t}=-23.01 \cdot p s i
$$

Primary membrane stress intensities at center:

$s_{1 t}:=\left|\left(\sigma_{p r t}+\sigma 1 p r t\right)-\left(\sigma_{p h t}+\sigma p_{p h t}\right)\right| \quad s_{1 t}=0 \cdot p s i$

$s_{2 t}:=\left|\left(\sigma_{p r t}+\sigma l_{p r t}\right)-\sigma_{p l t}\right| \quad s_{2 t}=1663 \cdot p s i$

$s_{3 t}:=\left|\sigma_{p l t}-\left(\sigma_{p h t}+\sigma l p h t\right)\right| \quad s_{3 t}=1663 \cdot p s i$

Margin of Safety on primary membrane stress of top plate:

$$
M S_{\mathrm{tp}}:=\frac{\mathrm{s}_{\mathrm{m}}}{\mathrm{s}_{2 \mathrm{t}}}-1 \quad \text { MS } \mathrm{tp}_{\mathrm{tp}}=8.2
$$


Bottom plate inside surface: $\quad x_{b}=-\frac{h_{b}}{2}$

Radial stress from pressure;

$\sigma_{p r b}=\frac{x_{b} \cdot \Delta p_{r e x}}{h_{b} \cdot\left(\frac{h_{b}}{r_{o}}\right)^{2}} \cdot F_{b 2} \quad \sigma_{p r b}=-934 \cdot p s j$

Hoop stress from pressure:

$\sigma_{p h b}=\frac{x_{b} \cdot \Delta p_{r e x}}{h_{b} \cdot\left(\frac{h_{b}}{r_{o}}\right)^{2}} \cdot F_{b 2} \quad \sigma_{p h b}=-934 \cdot p s i$
Radial stress from edge loads:

$$
\sigma I_{\text {prb }}=\frac{Q_{1}}{h_{b}}-\frac{12 \cdot x_{b}}{h_{b}{ }^{3}} \cdot M_{1} \quad \sigma l_{p r b}=307 * \text { psi }
$$

Hoop stress from edge loads:

$\sigma 1_{\text {phb }}:=\frac{Q_{1}}{h_{b}}-\frac{12 \cdot x_{b}}{h_{b}{ }^{3}} \cdot M_{1} \quad \sigma l_{p h b}=307 \cdot p s i$

Longitudinal stress from pressure:

$$
\sigma_{\mathrm{plb}}:=\frac{\Delta \mathrm{p}_{\mathrm{rex}}}{\mathrm{h}_{\mathrm{b}}} \cdot\left(x_{\mathrm{b}}-\frac{\mathrm{h}_{\mathrm{b}}}{2}\right) \quad \sigma_{\mathrm{plb}}=-23.01 \cdot \mathrm{psi}
$$

Prinary membrane stress intensities at center:

$$
\begin{aligned}
& s_{1 b}:=\left|\left(\sigma_{p r b}+\sigma l_{p r b}\right)-\left(\sigma_{p h b}+\sigma 1 p h b\right)\right| \quad s_{1 t}=0 \cdot p s i \\
& s_{2 b}:=\left|\left(\sigma_{p r b}+\sigma I_{p r b}\right)-\sigma_{p l b}\right| \quad s_{2 b}=604 \cdot p s i \\
& s_{3 b}:=\left|\sigma_{p l b}-\left(\sigma_{p h b}+\sigma l_{p h b}\right)\right| \quad s_{3 b}=604 \cdot p s i
\end{aligned}
$$

Margin of Safety on primary membrane stress of bottom plate:

$$
M S_{b p}:=\frac{s m}{s_{2 b}}-1 \quad M S_{b p}=24.32
$$


HNF-SD-TP-SARP-023 Rev, 0

\subsubsection{Drop g-loading Evaluation}

The Doorstop sample carrier and Doorstop container are carried inside a DOT 17H 55-gallon drum which in turn is contained inside an N-55 overpack. The overpack is used to carry radioactive payloads which can be contained in the 55-gallon drum and result in an assembly gross weight less than 750 ib. The $\mathrm{N}-55$ provides both impact and fire protection because of its layer of foam which completely surrounds the 55-gallon drum.

Two payloads of interest are commonly carried in the $\mathrm{N}-55$ at Hanford. One is the Sample Pig Shipping Container carrying a Sample Pig. The Sample Pig Shipping Container is a shielded container roughly 9 in. in diameter by $13 \mathrm{in.}$ long. The 1id/container interface consists of a bolted flange with a sealing 0-ring. This container is considered to be the containment boundary. The Sample Pig Shipping Container is surrounded by a drum spacer assembly made of layers of a Celotex-like material. The second payload consists of up to seven Doorstop sample carriers which are each inserted into a Doorstop container. The Doorstop containers are carried in a drum spacer assembly made of expanded polystyrene with plywood sheets above and below the Doorstop containers. The Doorstop containers are roughly 6 in. in diameter and 11 in. long. Each weighs approximately 32 1b. The Doorstop sample carriers each weigh approximately $321 \mathrm{~b}$.

The Doorstop Sample Carrier System has been shown to meet the drop test requirements of 10 CFR 71 by comparing the System with two similar packages which have successfully passed these tests. First, the $\mathrm{N}-55$ has been successfully drop tested as part of its certification process (NuPac 1987). In these tests, a 55-gallon drum containing sand was used for the payload which resulted in an assembly weight of $750 \mathrm{lb}$. The tests produced minimal damage to the $55-\mathrm{gall}$ on drum. The 1 id seal remained intact as shown by a post drop leak test. The second test considered was conducted recently to demonstrate the ability of the Sample Pig Transport System to meet the 10 CFR 71 requirements. The Sample Pig Transport System is similar to the Doorstop Sample Carrier System in that both payloads are carried in a 55-gallon drum contained in an N-55 overpack. In addition, both payloads are positioned inside the drum by a spacer assembly constructed of crushable material. The test consisted of three drops at different orientations from a height of $30 \mathrm{ft}$. The drop orientations were:

- End drop. The centerline of the overpack is vertical at the instant of impact on the overpack end.

- Side drop. The centerline of the overpack is horizontal at the time of impact on the side of the overpack.

- Corner drop. The center of gravity of the package is directly over the point of impact on the upper "corner" of the overpack. line connecting the point of impact with the package center of gravity would be vertical at the instant of impact.

The drop test sequence resulted in no visible damage to the Sample Pig Shipping Container. In addition to the visual inspection, the container was leak tested before and after the drop test and met leak rate requirements in both tests. 
The $\mathrm{N}-55$ overpack experienced permanent deformation from each of the three drops. Inspection of the spacer assembly inside the 55-gallon drum showed some deformation had also occurred. This damage resulted from the Sample Pig Container crushing some of the material of the spacer assembly around it. Figure B7.6.1.4-1 summarizes the magnitude of the external damage. The amount of deformation can be used to indicate the impact loads experienced by the overpack during the deformation. This analysis is described below.

Figure B7.6.1.4-1. Drop Test Damage.

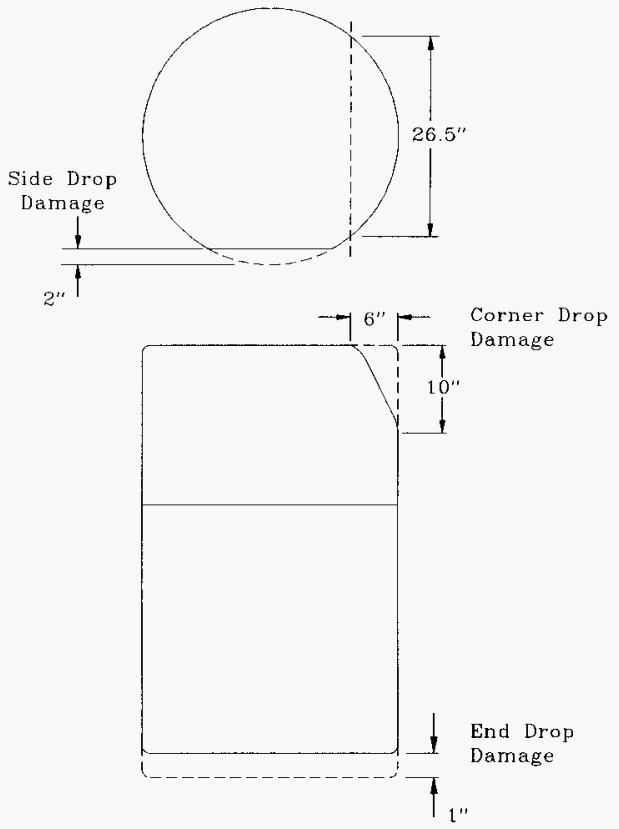

The Sample Pig drop test described in the Sample Pig Transport System SARP (WHC-SD-TP-TR-002, Rev.1) can be used to estimate the impact loads experienced by the Doorstop container. The two packages are similar in that both containment vessels are packaged inside the 55-gallon drum using internal spacer assemblies. The Doorstop uses a spacer assembly made of expanded polystyrene boards ("beadboard") while the Sample Pig is contained in a spacer assembly built of Celotex. Both internal arrangements allow considerable impact energy absorption in addition to that provided by the $\mathrm{N}-55$ foam. 
7.6.1.4.1 Side Drop. The Sample Pig internal energy absorption was estimated above to be $47 \%$ of the total energy. As mentioned above, this was in addition to the primary impact protection provided by the $\mathrm{N}-55$. If we assume similar impact conditions, a similar logic can be used to estimate the load experienced by the Doorstop container. Table B7.6.1.4-1 shows a CASKDROP analysis for a Doorstop assembly carried in an $\mathrm{N}-55$. If we assume a similar percentage of energy absorbed by the $\mathrm{N}-55$ in this case as in the Sample Pig, we get an energy value of $(0.53)(260,000$ in-1b) $=137,800$ in-1b which corresponds to a deflection of approximately 3.1 in. and an impact deceleration of $154 \mathrm{~g}$ 's. The remaining energy $(122,200 \mathrm{in}-1 \mathrm{~b})$ is then assumed to be absorbed by the spacer assembly inside the 55-gallon drum. Again, assuming a different elastic rebound as was done with the Sample Pig, an energy absorption number for the $\mathrm{N}-55$ becomes $0.66(260,000$ in-1b) $=$ 171,600 in-1b. The corresponding deflection and impact load values (again from Table B7.6.1.4-1) are approximately $3.3 \mathrm{in}$. and $188 \mathrm{~g}$ 's.

7.6.1.4.2 End Drop. The end drop results from CASKDROP are given in Table B7.6.1.4-2. These results indicate that sufficient foam is available to absorb the impact energy without the internal spacer assembly. If this were to be the case, the resulting impact load is shown as $140.0 g^{\prime} \mathrm{s}$. Using the Sample Pig results and the same elastic crush assumptions as used for the Sample Pig case, an even lower impact load results. For the Sample Pig case using an elastic plus permanent deflection of 1.5 in., (1.45*1.0 in.), CASKDROP gave an impact of $138.2 \mathrm{~g}$ 's and $113,568 \mathrm{ft}-1 \mathrm{~b}$ of energy absorbed. This was $49 \%$ of the impact energy. Applying this to the Doorstop case, the resulting energy is $0.49(260,000 \mathrm{in}-1 \mathrm{~b})=127,400 \mathrm{in}-1 \mathrm{~b}$. This corresponds to a deflection of approximately $1.7 \mathrm{in}$. and an impact load of $130 \mathrm{~g}$ 's.

7.6.1.4.3 Corner Drop. The corner drop results from CASKDROP are given in Table B7.6.1.4-3. Again, insufficient foam is available to absorb all of the impact energy. If we assume complete crushing of the available foam in this case, approximately $38 \%$ of the impact energy is absorbed. This results in a deflection of $7.3 \mathrm{in}$. and an impact load of only $52.4 \mathrm{~g}$ s. The deflection values derived above are perhaps somewhat lower than would actually occur because past testing has shown some damage to the impacted corner of the $55-$ gallon drum. This would be acceptable in this case since a large amount of spacer material protects the Doorstop containers and since the 55-gallon drum is not required to provide any containment. Even with this possibility, the impact accelerations are quite low for this case and therefore the corner drop is not considered a limiting factor for the design. 
HNF-SD-TP-SARP-023 ReV. 0

Table B7.6.1.4-1. CASKDROP Output, Side Drop.

\begin{tabular}{|c|c|c|c|c|}
\hline \multicolumn{5}{|c|}{ xis type B Overpack with sampie Is } \\
\hline 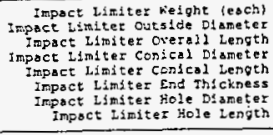 & $\begin{array}{r}=123 \\
=\quad 32.0000 \\
=\quad 21.0000 \\
=0.0000 \\
=0.0000 \\
=\quad 6.5000 \\
=0.0000 \\
=0.0000\end{array}$ & $\begin{array}{l}\text { ins } \\
\text { in } \\
\text { in } \\
\text { in } \\
\text { in } \\
\text { in } \\
\text { in } \\
\text { in }\end{array}$ & 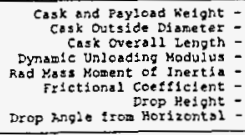 & 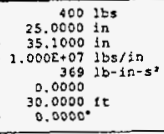 \\
\hline $\begin{array}{l}\text { Urbacked hrea Threshbold strain } \\
\text { Unbacked Area Crush stress }\end{array}$ & $\begin{array}{r}0.1000 \\
-\quad 87\end{array}$ & & $\begin{array}{l}\text { Crush Anslysis Theory - } \\
\text { Nurbe: of integraticn Incs - }\end{array}$ & $\begin{array}{r}610581 \\
20\end{array}$ \\
\hline
\end{tabular}

\begin{tabular}{|c|c|}
\hline \multicolumn{2}{|c|}{ 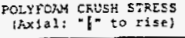 } \\
\hline $\begin{array}{r}\text { Density }= \\
\text { iemp }= \\
\text { o-yield } \\
\text { Eitss * }\end{array}$ & $\begin{array}{l}3,000 \mathrm{pet} \\
70.000 \mathrm{~F} \\
153.2 \\
0.0008\end{array}$ \\
\hline$=\mid\{r \mid\{n\}$ & $\sigma(p \in D)$ \\
\hline $\begin{array}{l}0.000 \\
0.100 \\
0.200 \\
0.300 \\
0.200 \\
0.500 \\
0.600 \\
0.650 \\
0.700 \\
0.750 \\
0.600\end{array}$ & $\begin{array}{r}0.0 \\
153.2 \\
115.8 \\
122.2 \\
120.2 \\
103.6 \\
105.6 \\
110.9 \\
113.0 \\
64.9 \\
121.1\end{array}$ \\
\hline
\end{tabular}

\begin{tabular}{|c|c|}
\hline \multicolumn{2}{|c|}{$\begin{array}{l}\text { POLYFOAY CRUEH STFESS } \\
\text { IRAdial: -14 to risel }\end{array}$} \\
\hline $\begin{array}{r}\text { Dersity }= \\
\text { Temp }= \\
\text { cyield }= \\
\text { Eias }\end{array}$ & $\begin{array}{l}3.000 \text { pet } \\
70.000 \mathrm{~F} \\
86.6 \mathrm{ys} \\
30.0008\end{array}$ \\
\hline$=(15 / 2 n)$ & $0(D \leq 1)$ \\
\hline $\begin{array}{l}0.000 \\
0.200 \\
0.200 \\
0.300 \\
0.600 \\
0.500 \\
0.600 \\
0.650 \\
0.700 \\
0.750 \\
0.200\end{array}$ & $\begin{array}{r}9.0 \\
86.6 \\
26.6 \\
79.6 \\
68.4 \\
86.2 \\
96.5 \\
59.6 \\
58.6 \\
118.9 \\
276.8\end{array}$ \\
\hline
\end{tabular}

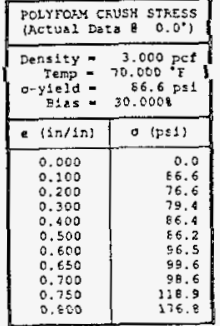

\begin{tabular}{|c|c|c|c|c|c|c|c|c|c|c|}
\hline $\begin{array}{l}\text { DEF } \\
(1 \pi)\end{array}$ & $(1)=$ & $\begin{array}{l}\operatorname{R} E \lambda \\
\{\operatorname{in} 2\}\end{array}$ & $\begin{array}{l}\text { voluse } \\
(12 \ldots 3)\end{array}$ & $\begin{array}{l}\text { SER } \\
\{\text { in\} }\end{array}$ & $\begin{array}{c}\text { IMFACE FORCE } \\
(1 \mathrm{bS})\end{array}$ & $\begin{array}{l}x c c E 2 \\
\left\{8^{\prime} s\right\}\end{array}$ & $\begin{array}{l}\text { I1 Novent } \\
\text { (1n-2bs) }\end{array}$ & $\begin{array}{c}\text { SAFAIN ENERCY } \\
(1 \mathrm{D}-2 \mathrm{bS})\end{array}$ & $\left\{\begin{array}{c}\text { XINETIC ENERGY } \\
(1 \mathrm{n}-1 \mathrm{ES})\end{array}\right.$ & $\begin{array}{l}\text { SE/KI } \\
\text { KXTID }\end{array}$ \\
\hline $\begin{array}{l}0.100 \\
0.200 \\
0.300 \\
0.400 \\
0.500 \\
0.600 \\
0.700 \\
0.600 \\
0.900 \\
1.000 \\
1.100 \\
1.200 \\
1.300 \\
1.400 \\
1.500 \\
1.600 \\
1.700 \\
1.600 \\
1.900 \\
2.000 \\
2.100 \\
2.200 \\
2.300 \\
2.400 \\
2.500 \\
2.600 \\
2.700 \\
2.800 \\
2.900 \\
3.000 \\
3.100 \\
3.200 \\
3.300 \\
3.400 \\
3.500\end{array}$ & $\begin{array}{l}2.86 \\
5.71 \\
8.57 \\
21.42 \\
14.28 \\
17.13 \\
19.99 \\
22.81 \\
25.70 \\
28.55 \\
31.41 \\
34.26 \\
37.12 \\
39.97 \\
42.83 \\
45.68 \\
48.54 \\
51.39 \\
54.25 \\
57.20 \\
59.96 \\
62.81 \\
65.67 \\
68.52 \\
72.38 \\
74.23 \\
77.09 \\
79.94 \\
82.80 \\
85.65 \\
88.59 \\
91.36 \\
94.22 \\
97.07 \\
99.53\end{array}$ & $\begin{array}{l}171 \\
242 \\
296 \\
361 \\
3 E 1 \\
417 \\
449 \\
480 \\
500 \\
595 \\
560 \\
5 E 4 \\
605 \\
628 \\
649 \\
676 \\
689 \\
708 \\
726 \\
744 \\
761 \\
777 \\
793 \\
809 \\
824 \\
839 \\
654 \\
868 \\
882 \\
855 \\
909 \\
922 \\
954 \\
947 \\
959\end{array}$ & $\begin{array}{r}12 \\
32 \\
59 \\
51 \\
227 \\
167 \\
221 \\
257 \\
307 \\
353 \\
513 \\
511 \\
530 \\
592 \\
656 \\
722 \\
795 \\
860 \\
931 \\
1,005 \\
2,050 \\
1,157 \\
1,236 \\
1,316 \\
1,398 \\
1,461 \\
2,565 \\
1,652 \\
1,739 \\
1,628 \\
1,928 \\
2,090 \\
2,203 \\
2,197 \\
2,292\end{array}$ & $\begin{array}{l}0.00 \\
0.00 \\
0.00 \\
0.00 \\
0.00 \\
0.00 \\
0.00 \\
0.00 \\
0.00 \\
0.00 \\
0.00 \\
0.00 \\
0.00 \\
0.00 \\
0.00 \\
0.00 \\
0.00 \\
0.00 \\
0.00 \\
0.00 \\
0.00 \\
0.00 \\
0.00 \\
0.00 \\
0.09 \\
0.00 \\
0.00 \\
0.00 \\
0.00 \\
0.00 \\
0.00 \\
0.00 \\
0.00 \\
0.00 \\
0.00\end{array}$ & $\begin{array}{r}2,637 \\
7,697 \\
13,163 \\
18,189 \\
22,090 \\
24,806 \\
25,739 \\
28,495 \\
30,631 \\
32,614 \\
34,972 \\
37,366 \\
39,274 \\
42,665 \\
44,201 \\
66,191 \\
48,116 \\
50,097 \\
52,236 \\
54,542 \\
56,964 \\
59,408 \\
69,684 \\
63,664 \\
65,750 \\
69,729 \\
73,534 \\
80,510 \\
89,173 \\
99,062 \\
109,976 \\
121,792 \\
136,373 \\
147,662 \\
161,611\end{array}$ & $\begin{array}{r}4.4 \\
11.9 \\
20.4 \\
28.2 \\
34.2 \\
38.4 \\
41.5 \\
44.1 \\
47.1 \\
50.5 \\
54.1 \\
57.9 \\
61.6 \\
65.1 \\
68.4 \\
71.5 \\
74.5 \\
77.5 \\
60.9 \\
84.4 \\
88.2 \\
92.0 \\
95.5 \\
98.6 \\
101.8 \\
106.4 \\
213.8 \\
124.6 \\
238.0 \\
153.3 \\
170.2 \\
168.3 \\
208.0 \\
228.6 \\
250.2\end{array}$ & $\begin{array}{l}0 \\
0 \\
0 \\
0 \\
0 \\
0 \\
0 \\
0 \\
0 \\
0 \\
0 \\
0 \\
0 \\
0 \\
0 \\
0 \\
0 \\
0 \\
0 \\
0 \\
0 \\
0 \\
0 \\
0 \\
0 \\
0 \\
0 \\
0 \\
0 \\
0 \\
0 \\
0 \\
0 \\
0 \\
0\end{array}$ & $\begin{array}{r}142 \\
669 \\
1,712 \\
3,200 \\
5,294 \\
7,639 \\
10,216 \\
12,978 \\
15,521 \\
19,077 \\
22,456 \\
26,074 \\
29,932 \\
35,024 \\
32,337 \\
42,557 \\
47,572 \\
52,583 \\
57,509 \\
62,938 \\
68,513 \\
74,332 \\
80,3 \in 6 \\
86,654 \\
93,325 \\
50,869 \\
106,562 \\
314,664 \\
123,249 \\
132,561 \\
143,012 \\
154,601 \\
167,409 \\
281,511 \\
296,975\end{array}$ & $\begin{array}{l}232,625 \\
232,669 \\
232,754 \\
232,818 \\
232,833 \\
232,968 \\
233,012 \\
233,077 \\
233,141 \\
233,206 \\
233,271 \\
233,335 \\
233,400 \\
233,564 \\
233,529 \\
233,594 \\
233,658 \\
233,723 \\
233,787 \\
233,852 \\
233,917 \\
233,981 \\
234,056 \\
234,110 \\
234,275 \\
234,250 \\
234,304 \\
234,369 \\
234,433 \\
234,498 \\
234,863 \\
234,627 \\
234,692 \\
234,756 \\
234,021\end{array}$ & $\begin{array}{l}0.00 \\
0.00 \\
0.01 \\
0.01 \\
0.02 \\
0.03 \\
0.04 \\
0.06 \\
0.07 \\
0.08 \\
0.10 \\
0.12 \\
0.13 \\
0.15 \\
0.16 \\
0.28 \\
0.20 \\
0.22 \\
0.25 \\
0.27 \\
0.29 \\
0.32 \\
0.34 \\
0.37 \\
0.40 \\
0.43 \\
0.66 \\
0.59 \\
0.53 \\
0.57 \\
0.67 \\
0.66 \\
0.71 \\
0.77 \\
0.84\end{array}$ \\
\hline
\end{tabular}

STe 
HNF-SD-TP-SARP-023 ReV. 0

Table B7.6.1.4-2. CASKDROP Output, End Drop. (Sheet 1 of 2)

\begin{tabular}{|c|c|c|c|c|}
\hline \multicolumn{5}{|c|}{ N-55 type B overpack w1th sample p1q } \\
\hline 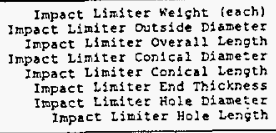 & $\begin{array}{rr}- & 123 \\
-\quad 32.0000 \\
-\quad 24.0000 \\
-\quad 0.0000 \\
=\quad 0.0000 \\
=\quad 6.5000 \\
=\quad 0.0000 \\
=\quad 0.0000\end{array}$ & $\begin{array}{l}\text { in } \\
\ln \\
\ln \\
\ln \\
\ln \\
\ln \\
\ln \\
\text { in }\end{array}$ & 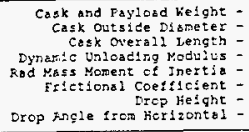 & $\begin{array}{rl}400 & \text { ibs } \\
25.0000 & \text { in } \\
35.1000 & \text { in } \\
1.000 E+07 & \text { ibs/in } \\
369 & 1 b-1 n-s^{2} \\
0.0000 & \\
30.0000 \text { ft } \\
90.0000^{-}\end{array}$ \\
\hline $\begin{array}{c}\text { Unbacked hics Threshold stiain } \\
\text { Unbocked trea crush stiess }\end{array}$ & $\begin{array}{l}=0.10001 \\
=\quad 153\end{array}$ & $\begin{array}{l}\ln / 1 n \\
p \leq 1\end{array}$ & $\begin{array}{l}\text { Crush Rralys is Thecry - } \\
\text { Number of Integration Incs - }\end{array}$ & $\operatorname{cloba} 20$ \\
\hline
\end{tabular}

\begin{tabular}{|c|c|c|c|c|c|}
\hline \multicolumn{2}{|c|}{ 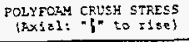 } & \multicolumn{2}{|c|}{$\begin{array}{l}\text { POLYFOLM CRUSH STFISS } \\
\text { (Fedial: II to ItSE) }\end{array}$} & \multicolumn{2}{|c|}{$\begin{array}{l}\text { POIYFOAN CRUSH SIFISS } \\
\text { (ACIUAL DATA } 90.0^{\circ} \text { ) }\end{array}$} \\
\hline \multicolumn{2}{|c|}{$\begin{aligned} \text { Density } & =3.000 \mathrm{pef} \\
\text { Temp } & =70.000 \mathrm{~F} \\
\text { c-yeld } & =153.2 \mathrm{Fs} \\
\text { Bias } & =30.000 \mathrm{~g}\end{aligned}$} & \multicolumn{2}{|c|}{$\begin{aligned} \text { Dersity } & =3.000 \mathrm{pet} \\
\text { Temp } & =70.000 \mathrm{~F} \\
\text { e-yie?d } & \mathrm{F} 6.5 \mathrm{Fsi} \\
\text { Eiss } & =30.0006\end{aligned}$} & \multicolumn{2}{|c|}{$\begin{aligned} \text { Density } & =3.000 \text { pet } \\
\text { Terp } & =70.000 \text { E } \\
\text { c-yteld } & =1.3 .2 \mathrm{FEL} \\
\text { Bias } & =30.000 \mathrm{E}\end{aligned}$} \\
\hline e $(1 n / 1 n)$ & $\sigma(F \leq 1)$ & $e|i \pi / i n|$ & $d \mid p \leq i\}$ & $e\{i n / i n\}$ & $0\{-5:\}$ \\
\hline $\begin{array}{l}0.000 \\
0.100 \\
0.200 \\
0.300 \\
0.400 \\
0.500 \\
0.600 \\
0.650 \\
0.700 \\
0.750 \\
0.800\end{array}$ & $\begin{array}{r}0.0 \\
153.2 \\
125.8 \\
112.2 \\
120.2 \\
103.6 \\
105.6 \\
114.9 \\
113.0 \\
80.9 \\
121.1\end{array}$ & $\begin{array}{l}3.500 \\
0.200 \\
0.200 \\
0.200 \\
0.400 \\
0.500 \\
0.600 \\
0.650 \\
0.760 \\
0.750 \\
0.800\end{array}$ & $\begin{array}{r}0.9 \\
86.6 \\
76.6 \\
79.4 \\
86.4 \\
66.2 \\
56.5 \\
90.6 \\
68.6 \\
116.9 \\
176.8\end{array}$ & $\begin{array}{l}0.500 \\
0.200 \\
0.200 \\
0.300 \\
0.400 \\
0.500 \\
0.600 \\
0.650 \\
0.700 \\
0.750 \\
0.800\end{array}$ & $\begin{array}{r}0.0 \\
153.2 \\
125.8 \\
122.2 \\
220.2 \\
103.6 \\
105.6 \\
174.9 \\
113.0 \\
64.9 \\
121.1\end{array}$ \\
\hline
\end{tabular}

\begin{tabular}{|c|c|c|c|c|c|c|c|c|c|c|}
\hline $\begin{array}{l}\text { DEFL } \\
\text { (1n) }\end{array}$ & $\underset{(8)}{\operatorname{mix}}=$ & $\begin{array}{l}A R E A \\
(1 \pi 2)\end{array}$ & $\begin{array}{c}\text { VoLte:E } \\
\text { (1n3) }\end{array}$ & $\begin{array}{l}X E R R \\
(i n)\end{array}$ & $\begin{array}{c}\text { IKFACT TORCE } \\
\text { (1ts) }\end{array}$ & $\begin{array}{l}2 C C E L \\
\left(0^{\circ} 5\right)\end{array}$ & $\begin{array}{l}I / L \text { Masil } \\
(|s-1 b s|\end{array}$ & $\begin{array}{c}\text { STFR IN E:SEGY } \\
(\text { (In-1Es) }\end{array}$ & $\mid \begin{array}{c}\text { KIKEIIC ENERGY } \\
(1 n-1 \text { Ls })\end{array}$ & $\begin{array}{l}\text { SEIKE } \\
\text { RITIO }\end{array}$ \\
\hline $\begin{array}{l}0.100 \\
0.200 \\
0.300 \\
0.400 \\
0.500 \\
0.600 \\
0.700 \\
0.800 \\
0.900 \\
1.000 \\
1.100 \\
1.200 \\
1.300 \\
1.100 \\
1.500 \\
1.600 \\
1.700 \\
1.800 \\
1.900 \\
2.000 \\
2.100 \\
2.200 \\
2.300 \\
2.600\end{array}$ & $\begin{array}{l}1.54 \\
3.08 \\
4.62 \\
6.15 \\
3.69 \\
9.23 \\
10.77 \\
12.31 \\
23.85 \\
15.38 \\
16.92 \\
28.86 \\
20.00 \\
21.54 \\
23.08 \\
24.62 \\
26.15 \\
27.69 \\
29.23 \\
30.77 \\
32.31 \\
33.85 \\
35.38 \\
36.92\end{array}$ & $\begin{array}{l}804 \\
804 \\
E 04 \\
804 \\
804 \\
804 \\
804 \\
804 \\
804 \\
804 \\
804 \\
804 \\
804 \\
804 \\
804 \\
804 \\
804 \\
504 \\
804 \\
E 04 \\
604 \\
E 04 \\
804 \\
804\end{array}$ & $\begin{array}{r}80 \\
161 \\
211 \\
322 \\
502 \\
483 \\
563 \\
643 \\
724 \\
804 \\
665 \\
965 \\
1,066 \\
1,126 \\
1,206 \\
1,267 \\
1,367 \\
1,458 \\
1,528 \\
1,608 \\
1,669 \\
1,769 \\
1,850 \\
1,930\end{array}$ & $\begin{array}{l}0.00 \\
0.00 \\
0.00 \\
0.00 \\
0.00 \\
0.00 \\
0.00 \\
0.00 \\
0.00 \\
0.00 \\
0.00 \\
0.00 \\
0.00 \\
0.00 \\
0.00 \\
0.00 \\
0.00 \\
0.00 \\
0.00 \\
0.00 \\
0.00 \\
0.00 \\
0.00 \\
0.00\end{array}$ & $\begin{array}{r}18,202 \\
35,823 \\
52,286 \\
67,006 \\
19,605 \\
69,002 \\
54,567 \\
97,655 \\
97,613 \\
96,235 \\
93,735 \\
91,127 \\
69,227 \\
68,660 \\
69,300 \\
50,533 \\
92,955 \\
95,323 \\
97,651 \\
99,624 \\
101,110 \\
102,153 \\
102,605 \\
103,117\end{array}$ & $\begin{array}{r}28.2 \\
55.5 \\
60.9 \\
103.9 \\
122.9 \\
137.6 \\
147.0 \\
151.2 \\
151.4 \\
149.0 \\
145.1 \\
141.2 \\
138.2 \\
137.2 \\
138.2 \\
140.6 \\
143.9 \\
147.6 \\
151.2 \\
154.2 \\
156.5 \\
158.1 \\
159.1 \\
159.5\end{array}$ & $\begin{array}{l}0 \\
0 \\
0 \\
0 \\
0 \\
0 \\
0 \\
0 \\
0 \\
0 \\
0 \\
0 \\
0 \\
0 \\
0 \\
0 \\
0 \\
0 \\
0 \\
0 \\
0 \\
0 \\
0 \\
0\end{array}$ & $\begin{array}{r}910 \\
3,611 \\
8,017 \\
13,582 \\
22,302 \\
28,717 \\
38,920 \\
48,540 \\
58,314 \\
68,026 \\
79,574 \\
66,758 \\
95,775 \\
104,670 \\
123,568 \\
122,574 \\
132,763 \\
161,276 \\
150,525 \\
260,659 \\
170,746 \\
380,589 \\
391,157 \\
201,433\end{array}$ & $\begin{array}{l}232,625 \\
232,889 \\
232,754 \\
232,82 \mathrm{~B} \\
232,863 \\
232,94 \mathrm{~B} \\
233,012 \\
233,077 \\
233,142 \\
233,206 \\
233,272 \\
253,325 \\
233,460 \\
233,564 \\
233,529 \\
233,594 \\
233,658 \\
233,723 \\
233,787 \\
233,852 \\
233,517 \\
233,961 \\
238,066 \\
230,110\end{array}$ & $\begin{array}{l}0.00 \\
0.02 \\
0.03 \\
0.06 \\
0.09 \\
0.13 \\
0.17 \\
0.21 \\
0.25 \\
0.29 \\
0.33 \\
0.37 \\
0.41 \\
0.45 \\
0.49 \\
0.52 \\
0.56 \\
0.60 \\
0.65 \\
0.69 \\
0.73 \\
0.77 \\
0.62 \\
0.66\end{array}$ \\
\hline
\end{tabular}

\section{BEST WHMABIE COPY}


Table B7.6.1.4-2. CASKDROP Output, End Drop. (Sheet 2 of 2)

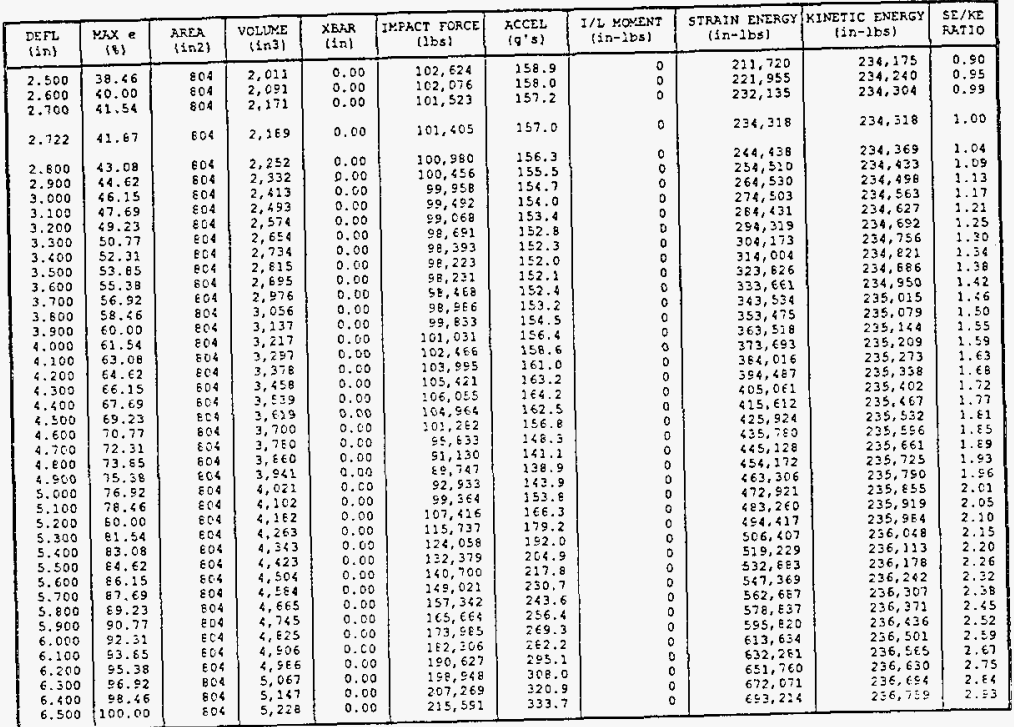


HNF-SD-TP-SARP-023 ReV. 0

Table B7.6.1.4-3. CASKDROP Output, Corner Drop. (Sheet 1 of 2)

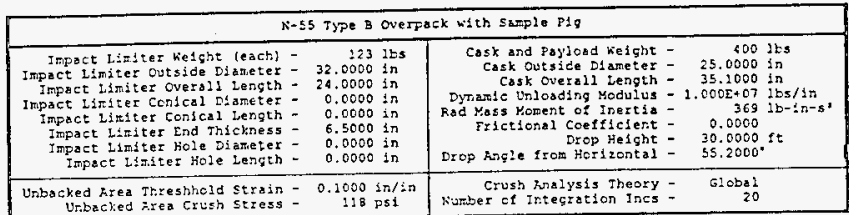

\begin{tabular}{|c|c|}
\hline \multicolumn{2}{|c|}{$\begin{array}{l}\text { FOLYFORM CRUSH STRESS } \\
\text { (fHX:21: If to Iise) }\end{array}$} \\
\hline $\begin{array}{r}\text { Density }= \\
\text { Ierp } \\
\text { o-yield }= \\
\text { Elas }=\end{array}$ & $\begin{array}{l}3.000 \mathrm{PCt} \\
70.000 \mathrm{~F} \\
153.2 \mathrm{FS1} \\
30.0008\end{array}$ \\
\hline$e(1 n / 5 n)$ & $0\{F \leq \leq\}$ \\
\hline $\begin{array}{l}0.000 \\
0.100 \\
0.200 \\
0.500 \\
0.400 \\
0.500 \\
0.600 \\
0.650 \\
0.700 \\
0.750 \\
0.800\end{array}$ & $\begin{array}{r}0.0 \\
153.2 \\
115.8 \\
212.2 \\
110.2 \\
103.6 \\
215.6 \\
112.9 \\
213.0 \\
13.9 \\
221.1\end{array}$ \\
\hline
\end{tabular}

\begin{tabular}{|c|c|}
\hline \multicolumn{2}{|c|}{$\begin{array}{l}\text { POLYFOLH CFUSH SIRESS } \\
\text { (Faciol: } 1 \text { to to rise) }\end{array}$} \\
\hline $\begin{array}{r}\text { Deneity }= \\
\text { Texp }= \\
\text { dyieid }= \\
\text { Elas }=\end{array}$ & $\begin{array}{l}3.000 \mathrm{Fcl} \\
30.000 \mathrm{~F} \\
86.6 \mathrm{psi} \\
30.0004\end{array}$ \\
\hline$\varepsilon(1 n / 1 n)$ & $a\{f \leq 1\}$ \\
\hline $\begin{array}{l}0.000 \\
0.160 \\
0.200 \\
0.300 \\
0.600 \\
0.500 \\
0.600 \\
0.650 \\
0.700 \\
0.750 \\
0.800\end{array}$ & $\begin{array}{r}0.0 \\
E E .6 \\
76.6 \\
79.4 \\
8 E .4 \\
E E .2 \\
96.5 \\
59.6 \\
98.6 \\
128.9 \\
176.8\end{array}$ \\
\hline
\end{tabular}

\begin{tabular}{|c|c|}
\hline \multicolumn{2}{|c|}{$\begin{array}{l}\text { POLYFOFM CRUSH STRESS } \\
\text { (Actual Data \& } 55.2^{\circ} \text { ) }\end{array}$} \\
\hline $\begin{array}{r}\text { Density }= \\
\text { Temp }= \\
0-y 1 c 1 d= \\
\text { Elbs }=\end{array}$ & $\begin{array}{l}3.000 \text { pet } \\
70.000 \text { "F } \\
227.7 \text { fs1 } \\
30.0008\end{array}$ \\
\hline e $\{1 n / 1 n\}$ & $\sigma(p \leq 1)$ \\
\hline $\begin{array}{l}0.000 \\
0.100 \\
0.200 \\
0.300 \\
0.400 \\
0.500 \\
0.600 \\
0.650 \\
0.700 \\
0.750 \\
0.800\end{array}$ & $\begin{array}{r}0.0 \\
127.7 \\
97.2 \\
57.5 \\
100.4 \\
56.9 \\
102.4 \\
109.2 \\
107.7 \\
92.6 \\
133.1\end{array}$ \\
\hline
\end{tabular}

\begin{tabular}{|c|c|c|c|c|c|c|c|c|c|c|}
\hline $\begin{array}{l}\text { DEFL } \\
(1 S)\end{array}$ & $\frac{k+x}{(5)}=$ & $\begin{array}{l}A \bar{P}=\mathrm{A} \\
\{1=2\}\end{array}$ & $\begin{array}{l}\text { volues } \\
\{i n \equiv\}\end{array}$ & $\begin{array}{l}X E R R \\
(1 n)\end{array}$ & $\begin{array}{c}\text { INFACI FCECE } \\
\text { (IDS) }\end{array}$ & $\begin{array}{l}\text { ACCEL } \\
\left(g^{\circ} s\right)\end{array}$ & $\begin{array}{l}I / L \text { NOWENT } \\
(1 n-16 s)\end{array}$ & $\begin{array}{c}\text { SIRAIN ENERGY } \\
(1 \mathrm{n}-2 \mathrm{LS})\end{array}$ & $\begin{array}{c}\text { KINETIC ENEFGY } \\
\text { (In+1bs) }\end{array}$ & $\begin{array}{l}\text { SE/KE } \\
\text { EKTIO }\end{array}$ \\
\hline $\begin{array}{l}0.100 \\
0.200 \\
0.300 \\
0.400 \\
0.500 \\
0.600 \\
0.700 \\
0.600 \\
0.900 \\
1.000 \\
1.100 \\
1.200 \\
1.200 \\
1.400 \\
1.500 \\
1.600 \\
1.700 \\
1.100 \\
1.900 \\
2.000 \\
2.100 \\
2.200 \\
2.300 \\
2.400\end{array}$ & $\begin{array}{r}1.26 \\
2.52 \\
3.78 \\
5.04 \\
6.30 \\
7.56 \\
8.82 \\
10.09 \\
11.34 \\
12.60 \\
73.86 \\
15.13 \\
16.39 \\
17.65 \\
18.91 \\
20.17 \\
21.43 \\
22.70 \\
23.96 \\
25.72 \\
26.48 \\
27.74 \\
29.01 \\
30.27\end{array}$ & $\begin{array}{l}1 \\
2 \\
3 \\
5 \\
7 \\
20 \\
12 \\
15 \\
38 \\
21 \\
74 \\
27 \\
11 \\
55 \\
58 \\
42 \\
46 \\
50 \\
54 \\
56 \\
63 \\
67 \\
32 \\
76\end{array}$ & $\begin{array}{l}0 \\
0 \\
0 \\
1 \\
2 \\
2 \\
3 \\
5 \\
6 \\
8 \\
11 \\
13 \\
16 \\
19 \\
23 \\
27 \\
32 \\
36 \\
42 \\
47 \\
53 \\
60 \\
67 \\
74\end{array}$ & $\begin{array}{l}-0.63 \\
-0.67 \\
-0.71 \\
-0.75 \\
-0.80 \\
-0.84 \\
-0.68 \\
-0.93 \\
-0.97 \\
-1.02 \\
-1.07 \\
-1.12 \\
-1.17 \\
-1.23 \\
-1.29 \\
-1.34 \\
-1.40 \\
-1.27 \\
-1.53 \\
-1.59 \\
-1.65 \\
-1.71 \\
-1.78 \\
-1.64\end{array}$ & $\begin{array}{r}5 \\
30 \\
82 \\
167 \\
257 \\
446 \\
642 \\
875 \\
1,141 \\
1,437 \\
1,757 \\
2,098 \\
2,458 \\
2,622 \\
3,157 \\
3,577 \\
3,561 \\
4,349 \\
4,740 \\
5,136 \\
5,538 \\
5,949 \\
6,368 \\
6,769\end{array}$ & $\begin{array}{r}0.0 \\
0.0 \\
0.1 \\
0.3 \\
0.4 \\
0.7 \\
1.0 \\
1.4 \\
1.8 \\
2.2 \\
2.7 \\
3.2 \\
3.8 \\
4.4 \\
4.9 \\
5.5 \\
6.1 \\
6.7 \\
7.3 \\
6.0 \\
8.6 \\
9.2 \\
9.9 \\
10.5\end{array}$ & $\begin{array}{l}0 \\
0 \\
0 \\
0 \\
0 \\
0 \\
0 \\
0 \\
0 \\
0 \\
0 \\
0 \\
0 \\
0 \\
0 \\
0 \\
0 \\
0 \\
0 \\
0 \\
0 \\
0 \\
0 \\
0\end{array}$ & $\begin{array}{r}0 \\
2 \\
8 \\
20 \\
43 \\
79 \\
134 \\
210 \\
310 \\
439 \\
599 \\
792 \\
1,019 \\
1,783 \\
1,564 \\
1,523 \\
2,300 \\
2,715 \\
3,270 \\
3,663 \\
4,257 \\
4,771 \\
5,367 \\
6,066\end{array}$ & $\begin{array}{l}232,625 \\
232,669 \\
232,754 \\
232,828 \\
232,883 \\
232,948 \\
233,022 \\
233,077 \\
233,141 \\
233,206 \\
233,271 \\
233,335 \\
233,400 \\
233,564 \\
233,529 \\
233,594 \\
233,659 \\
233,723 \\
233,797 \\
233,852 \\
233,917 \\
233,981 \\
234,046 \\
234,110\end{array}$ & $\begin{array}{l}0.00 \\
0.00 \\
0.00 \\
0.00 \\
0.00 \\
0.00 \\
0.00 \\
0.00 \\
0.00 \\
0.00 \\
0.00 \\
0.00 \\
0.00 \\
0.01 \\
0.01 \\
0.01 \\
0.01 \\
0.01 \\
0.01 \\
0.02 \\
0.02 \\
0.02 \\
0.02 \\
0.03\end{array}$ \\
\hline
\end{tabular}


HNF-SD-TP-SARP-023 ReV. 0

Table B7.6.1.4-3. CASKDROP Output, Corner Drop. (Sheet 2 of 2)

\begin{tabular}{|c|c|c|c|c|c|c|c|c|c|c|}
\hline $\begin{array}{l}D=F i \\
\mid 1 \mathrm{I})\end{array}$ & $\operatorname{mox}_{(i)} e$ & $\begin{array}{l}\operatorname{AR}=\pi \\
\left|2 \nabla^{2}\right|\end{array}$ & $\begin{array}{l}\text { Volume } \\
\text { (1n3) }\end{array}$ & $\begin{array}{l}x \operatorname{an} \pi \\
(1 \mathrm{n})\end{array}$ & $\begin{array}{c}\text { IMARCT FORCE } \\
\text { (IbE) }\end{array}$ & $\begin{array}{l}\text { RCCEL } \\
\left(g^{\prime} s\right)\end{array}$ & $\begin{array}{l}\text { I/ MONENT } \\
(1 n-1 b s \mid\end{array}$ & $\begin{array}{l}\text { ETFAIN ENERGY } \\
(\alpha n-1 t S)\end{array}$ & $\begin{array}{c}\text { KENETIC ENEAGY } \\
\text { (in-13s) }\end{array}$ & $\begin{array}{l}\text { SE/KE } \\
\text { RATIO }\end{array}$ \\
\hline $\begin{array}{l}2.500 \\
2.600 \\
1.700 \\
2.600 \\
2.900 \\
3.000 \\
3.100 \\
3.200 \\
3.300 \\
3.400 \\
3.500 \\
3.600 \\
3.300 \\
3.600 \\
3.500 \\
4.000 \\
4.200 \\
4.200 \\
4.300 \\
4.400 \\
4.500 \\
4.600 \\
4.700 \\
4.600 \\
4.900 \\
5.000 \\
5.100 \\
5.200 \\
5.300 \\
5.400 \\
5.500 \\
5.600 \\
5.700 \\
3.800 \\
5.500 \\
6.000 \\
6.200 \\
6.200 \\
6.300 \\
6.450 \\
6.500 \\
6.600 \\
6.700 \\
6.800 \\
6.500 \\
7.000 \\
7.300 \\
7.200 \\
7.300 \\
\end{array}$ & 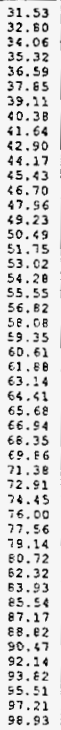 & 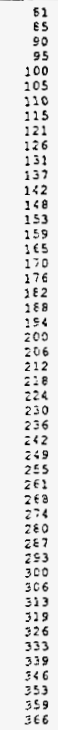 & 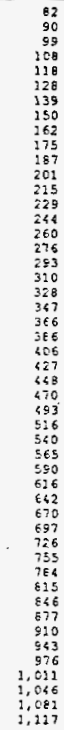 & 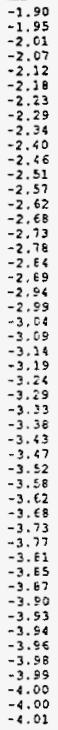 & 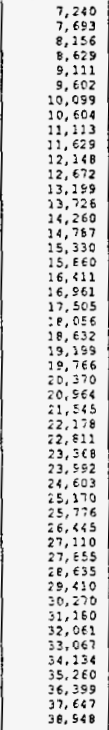 & $\begin{array}{l}21.2 \\
11.9 \\
12.6 \\
13.4 \\
14.1 \\
14.9 \\
15.6 \\
15.8 \\
17.2 \\
18.0 \\
28.8 \\
29.5 \\
20.4 \\
22.2 \\
22.1 \\
22.9 \\
23.7 \\
24.6 \\
25.4 \\
26.3 \\
27.2 \\
28.0 \\
29.8 \\
29.7 \\
30.6 \\
31.5 \\
32.5 \\
33.4 \\
34.3 \\
35.3 \\
36.2 \\
37.1 \\
38.2 \\
39.0 \\
33.9 \\
40.9 \\
42.0 \\
43.2 \\
44.3 \\
45.5 \\
26.9 \\
48.3 \\
49.6 \\
51.2 \\
52.8 \\
56.6 \\
56.3 \\
58.3 \\
60.3\end{array}$ & $\begin{array}{l}0 \\
0 \\
0 \\
0 \\
0 \\
0 \\
0 \\
0 \\
0 \\
0 \\
0 \\
0 \\
0 \\
0 \\
0 \\
0 \\
0 \\
0 \\
0 \\
0 \\
0 \\
0 \\
0 \\
0 \\
0 \\
0 \\
0 \\
0 \\
0 \\
0 \\
0 \\
0 \\
0 \\
0 \\
0 \\
0 \\
0 \\
0 \\
0 \\
0 \\
0 \\
0 \\
0 \\
0 \\
0 \\
0 \\
0 \\
0 \\
0\end{array}$ & 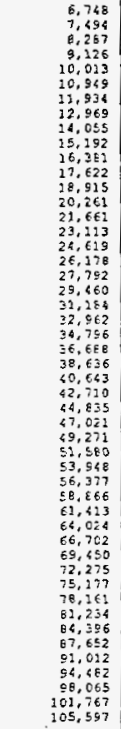 & 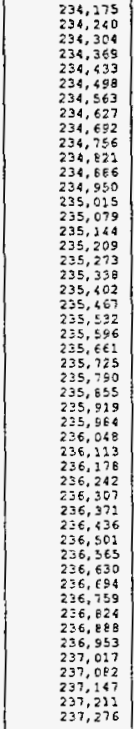 & 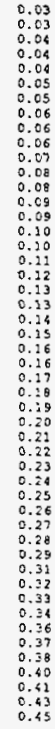 \\
\hline
\end{tabular}

Pas and

B7-36 
7.6.1.4.4 Internal Spacer Analysis. In order to get some idea of the internal deflection necessary inside the drum to absorb the excess energy not absorbed by the overpack in a side drop, a rough scoping calculation can be made using approximate properties of the spacer materials. The expanded polystyrene used has properties similar to the foam used in the N-55 (Woolam 1968). In fact it is shown to have better impact absorption characteristics than polyurethane foam of similar density. However it is much lighter than the overpack foam ( 1.8 pcf vs. 3.0 pcf) and thus can be expected to deform quickly in response to the impact loading. A stiffer portion of the spacer is the wood spacer plate which is part of the central spacer assembly. This is specified to be made of $1 / 2 \mathrm{in}$. marine plywood. A crude force deflection relation can be developed using the ultimate strength given for Douglas Fir (7420 psi, Roark and Young 1975) and derating the effective thickness by $\frac{1}{2}$ to account for the ply orientation in the plywood. (Wood is much stronger when crushed parallel to the grain than perpendicular to the grain). If we use a projected area equal to the effective thickness of the plywood times the diameter of a Doorstop container $(0.25$ in. $* 7420 \mathrm{psi} * 6$ in. $)=11,130$ in1b/in, each container crushing approximately 1.6 in. of wood absorbs a sufficient portion of the energy. This is ignoring the contribution of the polystyrene. If all spacer material was crushed completely so that the seven Doorstop containers were allowed to move to their lowest position in the 55gallon drum (Figure B7.6.1.4-2), their combined center of gravity shifts approximately $2.0 \mathrm{in}$. Thus, there is sufficient internal crush material to absorb the necessary energy and since it tends to be "softer" than the foam overpack, the loads experienced by the Doorstop are estimated to be less than the deceleration shown above for the entire package.

A brief examination of the impact capabilities of the Doorstop container is also in order. If we use a $200 \mathrm{~g}$ impact load to conservatively bound any values calculated above, these accelerations can be applied to the Doorstop container to evaluate its ability to withstand the impact. The internal pressure analyses contained in Part 8, Section B7.6.1.3 can be used to provide a basis for impact evaluation. Assume that the weight of the Doorstop is carried by either the base or the 1id of the Doorstop container. Applying the impact force due to the Doorstop as a pressure against the base or lid inside surface. The pressure is

$$
P=\frac{W a}{A}=\frac{32(200)}{\pi(5.5)^{2 / 4}}=269 p s i
$$

The internal pressure analysis gives a maximum bending stress in the lid of $774.4 \mathrm{psi}$ due to an internal pressure of $32 \mathrm{psi}$. Scaling this stress up for a 269 psi pressure results in a stress of $6510 \mathrm{psi}$. Similarly, the stress in the weld attaching the base to the cylinder wall scales to a value of 3231 psi. The threads in the lid are shown to be able to carry an axial load of $133,980 \mathrm{lb}$. The load due to Doorstop would be $6400 \mathrm{lb}$. These values indicate the Doorstop container is capable of withstanding the loads imposed by the $30 \mathrm{ft}$ drop requirement and that the containment boundary provided by the Doorstop container will remain intact. 
Figure 7.6.1.4-2. Spacer Material Stress-Strain Curve. Stress Strain Curve

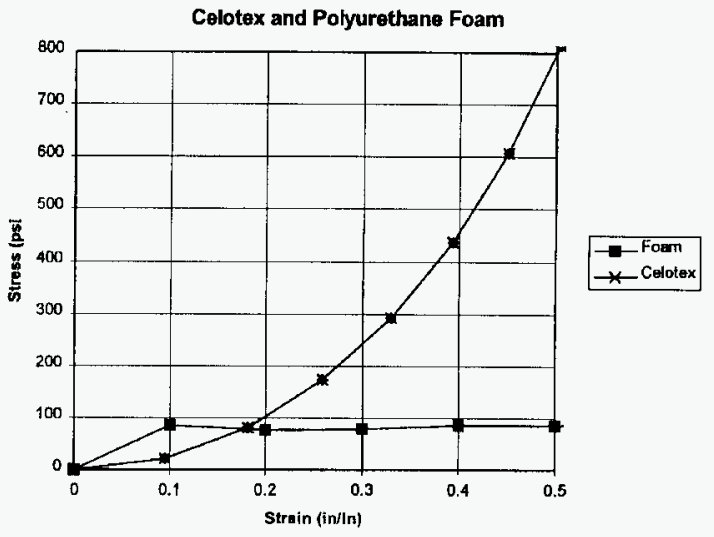




\subsubsection{References.}

NuPac, 1987, Safety Analysis Report for the NuPac N-55 Packaging, NRC Docket No. 71-9070, Nuclear Packaging, Inc., Federal Way, Washington.

Roark, R. J. and W. C. Young, 1975, Formulas for Stress and Strain, Fifth Edition, McGraw Hill Book Company, New York, New York.

Adkins, H. E., Jr., 1995, Pig Shipping Container Test Report, WHC-SD-TP-TR-002, Westinghouse Hanford Company, Richland, Washington.

Woolam, W. E., 1968, A Study of the Dynamics of Low Energy Cushioning Materials Using Scale Models, Journal of CELLULAR PLASTICS, New York, New York, February 1968. 
HNF-SD-TP-SARP-023 Rev. 0

\subsubsection{Vibration Analysis}

ENGINEERING SAFETY EVALUATION

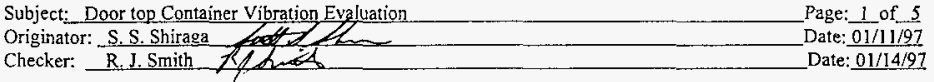

I. Objective:

The objective of this evaluation is determine the vibrational performance of the Door Stop container.

\section{References:}

ANSI, N14.23, Draft American National Standard Design Basis for Resistance to Shock and Vibration of Radioactive Material Packages Greater than One Ton in Truck Transport, American National Standard Institute, New York, New York, 1992.

RHO, Drawing No. H-2-73008, Rev 2, Door Stop Contoiner, Rockwell Hanford Operations, Richland, Washington, 1978.

Oberg, E., Jones, F. D., Holbrook, L. H., Ryffel, H. H., Machinery's Hanabook, 24 th Edition, Industrial Press Inc., New York, New York, 1992.

Hall, A. S., Holowenko, A. R., Laughlin, H. G., Theory and Problems of Machine Design, Schaum's Outline Series, McGraw-Hill Book Company, New York, New York, 1961.

Shigely, J. E., Mischke, C. R., Standard Handbook of Machine Design, McGraw-Hill Book Company, New York, New York, 1986

\section{Results and Conclusions:}

Results of this evaluation show that the Door Stop container closure will not loosen under the shock loads specified in ANSI N14.23 (ANSI 1992) nor is fatigue life a consideration. This is based on the assumption that the vector sum of the specified shock loads are applied in the worst orientation. The shock cvaluation is based on conservatively idealizing the lid closure as a power screw with no preload. The positive torque value determined, indicates that ovenauling will not occur and large torque is required to loosen the closure lid. Vibrational evaluation of the closure lid is conservatively based on unified thread stress theory. The evaluation shows the vibrational loads on the closure threads are negligible and are below the conservatively estimated endurance limit of the material. Consequently, fatigue life is not a concem with this container. 
HNF-SD-TP-SARP-023 Rev. 0

ENGINEERING SAFETY EVALUATION

Subject: Door top Container Vibration Evaluation

Page: 2 of 5

Originator: S.S. Shiraga DL

Date: $01 / 1 / 1 / 97$

Checker: R. J. Smith

RJS

Date: $\underline{01 / 14 / 97}$

\section{Evaluation:}

\section{Door Stop Vibration Evaluation:}

Since the seal is an elastomeric O-ring, assume the lid is only tightened hand tight. Determine shock loosening of the lid and fatigue load on threads. Use loading parameters from ANSI 14.23 (ANSI 1992).

Lid Weight Determination and Shock Loosening Evaluation:

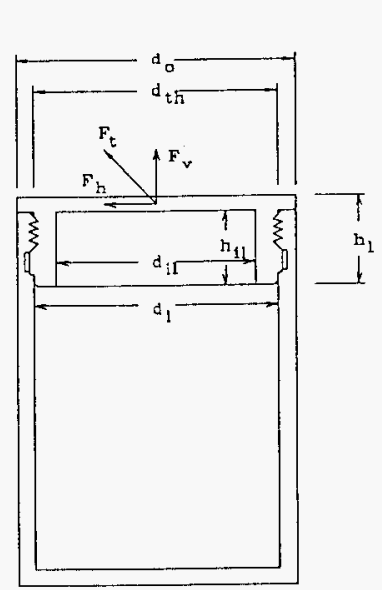

\section{Geometric parameters (RHO 1978):}

Assume generic $304 \mathrm{~L}$ stainless steel as matcrial.

Density of stainless stecl: $\quad \rho_{\text {st }}=0.29 \frac{\mathrm{lbf}}{\mathrm{in}^{3}}$

Total lid height: $\quad h_{1}=1.5 \cdot \mathrm{in}$

Height of lid inside: $\quad h_{i l}=1.0625$ in

OD of lid: $\quad \mathrm{d}_{\mathrm{o}}=6.38 \mathrm{in}$

ID of lid: $\quad d_{\mathrm{jl}}=5.12 \mathrm{in}$

ID of container: $\quad \mathrm{d}_{\mathrm{i}}=5.50 \mathrm{in}$

Loading shock parameters (ANS1 1992, page 10):

Vertical inertial load factor: $\quad g_{v}=2$

Longitudinal inertial load factor: $g_{\mid}=\mathbf{2 . 3}$

Lateral loading factor: $\quad g_{l_{3}}:=1.6$

Vibration frequency: $\quad \mathrm{f}_{\mathrm{hz}}:=2 \cdot \mathrm{Hz}$

Weight of lid:

$$
\begin{aligned}
& \qquad \mathrm{w}_{\mathrm{lid}}:=\left[\frac{\pi \cdot \mathrm{d}_{\mathrm{o}}^{2}}{4} \cdot\left(\mathrm{h}_{\mathrm{l}}-\mathrm{h}_{\mathrm{il}}\right)+\frac{\pi}{4} \cdot\left(\mathrm{d}_{\mathrm{i}}{ }^{2}-\mathrm{d}_{\mathrm{il}}{ }^{2}\right) \cdot \mathrm{h}_{\mathrm{il}}\right] \cdot \rho_{\mathrm{st}} \quad \mathrm{w}_{\mathrm{lid}}=5.03 \cdot \mathrm{lbf} \\
& \text { Vector sum of horizontal forces: } \quad \mathrm{F}_{\mathrm{h}}:=\sqrt{\left(\mathrm{g}_{\mathrm{la}} \cdot \mathrm{w}_{\mathrm{lid}}\right)^{2}+\left(\mathrm{g}_{\mathrm{l}} \cdot \mathrm{w}_{\mathrm{lid}}\right)^{2}} \quad \mathrm{~F}_{\mathrm{h}}=14.1 \cdot \mathrm{lbf} \\
& \text { Vertical force: } \quad \mathrm{F}_{\mathrm{v}}:=\mathrm{g}_{\mathrm{v}} \cdot \mathrm{w}_{\mathrm{w}} \mathrm{lid} \quad \mathrm{F}_{\mathrm{v}}=10.07 \cdot \mathrm{lbf} \\
& \text { Vector sum of horizontal and vertical forces: } \quad \mathrm{F}_{\mathrm{t}}=\sqrt{\mathrm{F}_{\mathrm{h}}{ }^{2}+\mathrm{F}_{\mathrm{v}}} \quad \mathrm{F}_{\mathrm{t}}=17.32 \cdot \mathrm{lbf}
\end{aligned}
$$


Since the lid is not preloaded to set value idealize as an evaluation of screw overhauling. Conservatively, assume that the vector sum loading forces are applied directly vertical to the lid.

Thread parameters (Oberg, et al 1992, page 1536) for 6-12UNC:

Nominal major thread external diameter: $d_{t h}:=6 . i n \quad$ Mean thread radius: $r_{m}: \frac{d_{\text {th }}}{2}$

Thread pitch: $\quad$ pit $:=\frac{12}{\text { in }} \quad$ Pitch length: $\quad p:=\frac{1}{\text { pit }} \quad p=0.08 \cdot$ in

Major diameter of internal thread: $\quad \mathrm{D}_{\mathrm{n}}:=6.000 \mathrm{in} \quad$ Minor diametcr of internal threads: $\mathrm{d}_{\mathrm{n}}:=5.9098$ in

Assumed coefficient of friction, based on metal to metal contact: $\quad \mu:=0.1$

Thread angle for unified threads: $\quad \theta:=30 \mathrm{deg} \quad$ Lead angle: $\quad \alpha=\operatorname{atan}\left(\frac{1}{2 \cdot \pi \cdot \text { pit }^{\prime} \mathrm{m}}\right) \quad \alpha=0.25 *$ deg

Tooth profile flank angle: $\quad \theta_{n}=\operatorname{atan}(\tan (\theta) \cdot \cos (\alpha)) \quad \theta_{n}=30 \cdot d e g$

Pitch diameter: $d_{p}=5.9459$ in $\quad$ Minor diameter of male threads: $\quad d_{s}:=5.900 \mathrm{sin}$

Active length of male threads (RHO 1978): $L_{e}=(0.64-0.1) \cdot \mathrm{in}$

Using floor function (Mathcad 1994), determine smallest integer of thread number:

Whole number of active threads; $\quad N_{\mathrm{e}}:=$ floor $\left(\mathrm{L}_{\mathrm{e}}\right.$ pit $) \quad \mathrm{N}_{\mathrm{e}}=6$

Width of the extemal thread at root (Oberg, et al 1992, page 1520): $w_{\text {th }}=p-0.25 p \quad w_{t h}=0.06 \cdot$ in

Assume no collar friction available and no gravity, conservatively detemnine tuming moment (Hall, et al 1961):

$$
T_{\text {los }}=F_{t} \cdot\left[r_{m i}\left[\frac{\tan (\alpha)+\frac{\mu}{\cos \left(\theta_{n}\right)}}{1+\frac{\mu \cdot \tan (\alpha)}{\cos \left(\theta_{n}\right)}}\right]\right] \quad T_{105}=0.48 \cdot \mathrm{ft} \cdot \mathrm{lbf}
$$

Since $T_{\text {los }}$ is positive, the lid will not loosen under the loading.

Determination of Thread Fatigue:

Assume gross weight of cask is: $\quad W_{\text {cask }}=64 \cdot \mathrm{lbf}$ 


\section{ENGINEERING SAFETY EVALUATION}

Subject: Door top Container Vibration Evaluation Originator: S.S. Shiraga

Ris

Since load is light, assume RMS force is the entire weight of cask multiplied by a factor of 2.3 (ANSI 1992).

$$
\mathrm{F}_{\mathrm{mms}}:=2.3 \mathrm{~W}_{\text {cask }} \quad \mathrm{F}_{\mathrm{rms}}=147.2 \cdot \mathrm{lbf}
$$

Assume no static load on the container and all loading is cyclic.

Determine thread stresses (Shigejy, et al 1986, page 20.6):

Bending stress at root of threads;

$$
\sigma_{b t h}=\frac{3 \cdot F_{m s^{\prime}}\left(d_{p}-d_{s}\right)}{\pi \cdot d_{p} \cdot N_{e} \cdot h t_{t h}^{2}} \quad \sigma_{b t h}=45 \cdot p s i
$$

Shear stress at root of threads:

$$
\tau_{t h}=\frac{4 \cdot F_{m s}}{3 \cdot \pi \cdot d_{s} \cdot w_{t h} \cdot N_{e}} \quad \tau_{t h}=28 \cdot p s i
$$

Bearing stress of threads:

$$
\text { Bearing stress geometry factor: } \varepsilon=\frac{\cos \left(\theta_{n}\right)}{\left(1+\tan \left(\theta_{n}\right)^{2} \cdot \cos (\alpha)^{2}\right)^{-\frac{1}{2}}-\mu \cdot \tan (\alpha)}
$$

$$
\text { Bearing stress: } \quad \sigma_{\text {bear }}:=\frac{4 \cdot F_{r m s} \cdot E}{\pi \cdot N_{c} \cdot\left(d_{t h}{ }^{2}-d_{n}{ }^{2}\right)} \quad \sigma_{\text {bear }}=29 \cdot p s i
$$

Hoop stress on container:

$$
\begin{aligned}
& \text { Hoop coefficient: } \quad \beta=\frac{\tan \left(\theta_{n}\right)}{1-\mu \cdot \tan (\alpha) \cdot \sqrt{1+\tan \left(\theta_{n}\right)^{2} \cdot \cos (\alpha)^{2}}} \quad \beta=0.58 \\
& \text { Hoop stress: } \quad \sigma_{h c}:=\frac{F}{\pi \cdot d n \cdot p \cdot \beta} \cdot\left(\frac{d_{0}{ }^{2}+D_{n}{ }^{2}}{d_{0}{ }^{2}-D_{n}{ }^{2}}\right) \quad \sigma_{h c}=149 \cdot p s i
\end{aligned}
$$

Total stress on internal threads including bearing and hoop:

$$
\text { Total stress: } \quad \sigma_{\text {tot }}:=\sigma_{\mathrm{bth}}+\tau_{\mathrm{th}}+\sigma_{\text {bear }}+\sigma_{\mathrm{hc}} \quad \sigma_{\text {tot }}=252 \cdot \mathrm{psi}
$$


HNF-SD-TP-SARP-023 ReV. 0

\section{ENGINEERING SAFETY EVALUATION}

Subject: Door top Container Vibration Evaluation

Originator: S. S. Shiraga

Checker: R. J. Smith

RSS

Determine endurance limit of assumed material (Shigely, et al 1986, page 13-11) :

Material assumed as generic stainless steel with properties of $304 \mathrm{~L}$ stainless steel.

Assume yield strength of material: $\quad s_{\mathrm{y}}:=33 \cdot \mathrm{ksi} \quad \mathrm{s}_{\mathrm{u}}=60 \mathrm{ksi}$

Surface condition factor (assume machined): $\quad k_{s}:=0.85$

Size modification factor: $\quad k_{b}:=0.79$

Reliability factor: $k_{c}:=0.5 \quad$ Temperature factor at room temperature: $\quad k_{t}=1$

Stress modification factor (based on thread concentration): $\quad k_{e}=\frac{1}{3}$.

Endurance stress: $\quad s_{e}=k_{s} \cdot k_{b} \cdot k_{c} \cdot k_{t} \cdot k_{e} \cdot s \quad y \quad s_{e}=3.69 \cdot k s i$

Since the cyclic loading stresses on the threads are ven low relative to the endurance limit of common generic $304 \mathrm{~L}$ stainless steel, vibrational fatigue loads on the container are negligible. Consequently, vibration loading is not an issue. 


$$
\text { HNF-SD-TP-SARP-023 Rev. } 0
$$

\subsubsection{Operating Instructions Change for $\mathrm{N}-55$ Overpack Evaluation}

7.6.2.1 Introduction. The loading instructions for the N-55 overpack as outlined in Certificate of Compliance (CoC) (9070) specifies securing the top half of the overpack to the bottom half by fastening the four toggle clamps (barrel pins). This is accomplished by adjusting the "T" bar on the clamps such that the clamps may be closed with minimum force. Reopen the clamps, and rotate the " $T$ " bar on al1 four clamps four full $360^{\circ}$ turns clockwise. Then close the clamps. Following these instructions has resulted in damage to the molded fiberglass inner shel1. To avoid destroying the $\mathrm{N}-55$ overpacks, an evaluation was made of the overpack closure and instructions.

7.6.2.2 Evaluation. The amount of gasket material available for compression before the liner material in the top and bottom half of the overpack makes contact was identified. Also identified was the distance the clamp moves when rotated four ful1 $360^{\circ}$ turns clockwise. By comparing the two distances, it was identified that the gasket material was being over compressed and that the inner liner was forced to flex. The force on the inner liner over time resulted in cracking of the fiberglass material.

To avoid damaging the liners, a decision was made to reduce the number of turns to the point where the gasket material was properly compressed, but the liner was not forces to flex. To arrive at the proper number of turns, the distance between the top and bottom liner when closed with a new gasket and only the weight of the top of the overpack providing compression was identified. This is the position the lid is to be in when the clamps are closed with minimum force. From this position, it was identified that two full $360^{\circ}$ turns clockwise would result in the proper amount of gasket compression without causing the inner liner to flex.

7.6.2.3 Conclusion. A discussion of the above findings was held with personnel of the overpack manufacturer. As a results of the discussions and the evaluation, a decision was made to change the overpack closure instruction for onsite use. The closure instruction for onsite use now states the following:

Secure the top half of the $\mathrm{N}-55$ overpack to the bottom half by fastening the four toggle clamps (barrel pins). This shall be done by adjusting the "T" bar on the clamps such that the clamps may be closed with minimum force. Reopen the clamps and rotate the "T" bar on all four clamps two full $360^{\circ}$ turns clockwise. Then close the clamps.

\subsubsection{Reference.}

NRC, 1987, Certificate of Compliance for the NuPac Model N-55 Overpack, CoC number 9070, Docket Number 71-9070, U.S. Nuclear Regulatory Commission, Washington, D.C. 
HNF-SD-TP-SARP-023 Rev. 0

This page intentionally left blank. 
HNF-SD-TP-SARP-023 Rev. 0

\subsection{THERMAL EVALUATION}

The purpose of this thermal evaluation is to determine the performance of the Doorstop containers under the normal and accident conditions with the $3 \mathrm{~W}$ heat load per container in the normal transport configuration. In accordance with Hanford Drawings $\mathrm{H}-2-73008, \mathrm{H}-2-73010$, and $\mathrm{H}-2-73033$, the normal transport configuration consists of seven Doorstop containers packed inside a DOT 208-L drum with polystyrene spacers. The DOT 208-L drum is shielded within a NuPac Type 3 overpack, Model N-55, Drawing (NuPac 1987). Two of these overpacks are shipped together at the same time on the transport.

\subsection{THERMAL SOURCE SPECIFICATION}

The assumed decay heat of each Doorstop container is $3 \mathrm{~W}$ from the liquid waste which has a specific gravity of 1.2 . The liquid volume is conservatively calculated based on the general dimension of the Doorstop container. It is also assumed that the liquid waste is filled up to a level of $3.18 \mathrm{~cm}$ (1.25 in.) below the bottom of the 1 id $(\mathrm{H}-2-73008)$. Based on the calculated liquid volume of $2989.98 \mathrm{~cm}_{3}\left(182.46 \mathrm{in}_{3}^{3}\right)$, the volumetric heat deposition density is $0.001 \mathrm{~W} / \mathrm{cm}^{3}\left(0.0562 \mathrm{Btu} / \mathrm{h}-\mathrm{in}^{3}\right)$.

The worst Hanford solar insolation is taken from Table l (Irwin 1996), which assumes the solar insolation for an average July day at the Hanford Site. Summing up the recommended 24 hour solar insolation and averaging over 12-hour period in accordance with the 10 CFR 71 guideline, the resulting solar insolation is $0.063 \mathrm{~W} / \mathrm{cm}^{2}\left(1.3808 \mathrm{Btu} / \mathrm{h}-\mathrm{in}^{2}\right)$. The above value is for a flat surface transported horizontally. For a curved vertical surface, the solar insolation is half of the above value; i.e., $0.0315 \mathrm{~W} / \mathrm{cm}^{2}\left(0.6904 \mathrm{Btu} / \mathrm{h}-\mathrm{in}^{2}\right)$. An additional reduction due to an absorptivity of 0.8 for the external surface of the overpack yields the solar insolation of $0.025 \mathrm{~W} / \mathrm{cm}^{2}\left(0.5523 \mathrm{Btu} / \mathrm{h}-\mathrm{in}^{2}\right)$.

\subsection{SUMMARY OF THERMAL PROPERTIES}

\subsubsection{Doorstop Container}

The Doorstop container is constructed of primarily 304 stainless steel, its thermo-physical properties are obtained from Table A-12a of the Thermal Analysis Methods for Safety Analysis Reports for Packaging (Irwin 1996) and summarized in Table B8-1. 
HNF-SD-TP-SARP-023 Rev. 0

Table B8-1. Material Properties of 304 Stainless Stee1.

\begin{tabular}{|c|c|c|c|}
\hline $\begin{array}{c}\text { Temperature } \\
{ }^{\circ} \mathrm{C}\left({ }^{\circ} \mathrm{F}\right) \\
\end{array}$ & $\begin{array}{l}\text { Thermal conductivity } \\
\mathrm{W} / \mathrm{m}^{\circ} \mathrm{K} \text { (Btu/h-in- } \mathrm{B} \text { ) }\end{array}$ & $\begin{array}{c}\text { Specific heat } \\
\mathrm{J} / \mathrm{kg}^{-} \mathrm{K}\left(\mathrm{B} \text { tu/lbm- }{ }^{-0} \mathrm{~F}\right)\end{array}$ & $\begin{array}{c}\text { Density } \\
\mathrm{kg} / \mathrm{cm}^{3}(\text { lbm/in } 3 \text { ) }\end{array}$ \\
\hline 0 (32) & $13.4(0.644)$ & $502(0.120)$ & $0.008(0.286)$ \\
\hline $20(70)$ & $14.8(0.713)$ & $456(0.109)$ & $0.008(0.286)$ \\
\hline $38(100)$ & $15.1(0.727)$ & $464(0.111)$ & $0.008(0.286)$ \\
\hline $93(200)$ & $16.1(0.774)$ & $485(0.116)$ & $0.008(0.286)$ \\
\hline $204(400)$ & $17.8(0.860)$ & $523(0.125)$ & $0.008(0.286)$ \\
\hline $316(600)$ & $19.6(0.943)$ & $544(0.130)$ & $0.008(0.286)$ \\
\hline $427(800)$ & $21.2(1.022)$ & $565(0.135)$ & $0.008(0.286)$ \\
\hline $649(1200)$ & $24.3(1.170)$ & $586(0.140)$ & $0.008(0.286)$ \\
\hline $760(1400)$ & $25.7(1.238)$ & $607(0.145)$ & $0.008(0.286)$ \\
\hline $816(1500)$ & $26.4(1.274)$ & $623(0.149)$ & $0.008(0.286)$ \\
\hline
\end{tabular}

\subsubsection{DOT 208-L Drum and Galvanized Steel Liner of Overpack}

The DOT 208-L drum and the galvanized steel liner of the $\mathrm{N}-55$ overpack are assumed to be constructed of mild carbon steel. The thermal and physical properties are obtained from Table A-18 of the Thermal Analysis Methods for Safety Analysis Reports for Packaging (Irwin 1996) and summarized in

Table B8-2.

Table B8-2. Material Properties of Mild Carbon Stee1.

\begin{tabular}{|c|c|c|c|}
\hline $\begin{array}{c}\text { Temperature } \\
{ }^{\circ} \mathrm{C}\left({ }^{\circ} \mathrm{F}\right)\end{array}$ & $\begin{array}{c}\text { Thermal Conductivity } \\
\mathrm{W} / \mathrm{m}^{\circ}{ }^{\circ} \mathrm{K}\left(\mathrm{Btu} / \mathrm{h}-\mathrm{in}^{\circ} \mathrm{F}\right)\end{array}$ & $\begin{array}{c}\text { Specific heat } \\
\mathrm{J} / \mathrm{kg}-^{\circ} \mathrm{K}\left(\mathrm{Btu} / \mathrm{bm}{ }^{\circ} \mathrm{F}\right)\end{array}$ & $\begin{array}{c}\text { Density } \\
\mathrm{kg} / \mathrm{cm}^{3}\left(\mathrm{bm} / \mathrm{in}^{3}\right)\end{array}$ \\
\hline \hline$-73(-100)$ & $43.1(2.076)$ & $502(0.120)$ & $0.008(0.280)$ \\
\hline$-17.8(0)$ & $43.1(2.076)$ & $502(0.120)$ & $0.008(0.280)$ \\
\hline $204(399)$ & $42.2(2.036)$ & $519(0.124)$ & $0.008(0.280)$ \\
\hline $423(800)$ & $38.6(1.860)$ & $619(0.148)$ & $0.008(0.280)$ \\
\hline $648(1198)$ & $32.2(1.552)$ & $753(0.180)$ & $0.008(0.280)$ \\
\hline $788(1450)$ & $25.9(1.250)$ & $837(0.200)$ & $0.008(0.280)$ \\
\hline
\end{tabular}

\subsubsection{Polystyrene}

The seven Doorstop containers inside the DOT 208-L drum are separated with expanded polystyrene bead boards. The thermal conductivity of polystyrene is obtained from Machine Design (Penton Publishing Inc. 1988),

Thermal conductivity $=0.48 \mathrm{~W} / \mathrm{m}-{ }^{\circ} \mathrm{K}\left(3.3 \mathrm{Btu}-\mathrm{in} / \mathrm{h}-\mathrm{ft}^{2}-{ }^{\circ} \mathrm{F}\right)$

The specific heat of the polystyrene is assumed the same as the processed polyurethane whose specific heat is presented in Table A-31 for polyurethane 


$$
\text { HNF-SD-TP-SARP-023 Rev. } 0
$$

foam (Irwin 1996),

$$
\text { Specific heat }=1677 \mathrm{~J} / \mathrm{kg}-{ }^{\circ} \mathrm{K}\left(0.4 \mathrm{Btu} / 1 \mathrm{bm}-{ }^{\circ} \mathrm{F}\right) \text {. }
$$

The density of the polystyrene used in the thermal evaluation is assumed to be $128 \mathrm{~kg} / \mathrm{m}^{3}\left[81 \mathrm{bm} / \mathrm{ft}^{3}\left(0.004631 \mathrm{bm} / \mathrm{in}^{3}\right)\right]$.

\subsubsection{Polyurethane}

The $\mathrm{N}-55$ overpack is made of foamed honeycomb polyurethane. The thermal conductivity of processed polyurethane is obtained from Machine Design (Penton Publishing Inc. 1988),

Thermal conductivity $=0.12 \mathrm{~W} / \mathrm{m}-{ }^{\circ} \mathrm{K}\left(0.8 \mathrm{Btu}-\mathrm{in} / \mathrm{h}-\mathrm{ft}^{2}-{ }^{\circ} \mathrm{F}\right)$

The specific heat of polyurethane is obtained from Table A-31 for the polyurethane foam (Irwin 1996),

Specific heat $=1677 \mathrm{~J} / \mathrm{kg}^{\circ}{ }^{\circ} \mathrm{K}\left(0.4 \mathrm{Btu} / 1 \mathrm{bm}-{ }^{\circ} \mathrm{F}\right)$.

The density of the polyurethane used in the thermal evaluation is assumed to be $128 \mathrm{~kg} / \mathrm{m}^{3}\left[81 \mathrm{bm} / \mathrm{ft}^{3}\left(0.004631 \mathrm{bm} / \mathrm{in}^{3}\right)\right]$.

\subsubsection{Fiberglass}

There is a layer of fiberglass on the inner surface of the $\mathrm{N}-55$ overpack. The fiberglass thermo-physical properties are adopted from Table A-35 of the low density fiberglass for the Pig Spacer at the highest given temperature (Irwin 1996),

$$
\begin{aligned}
& \text { Thermal conductivity }=0.04 \mathrm{~W} / \mathrm{m}-{ }^{\circ} \mathrm{K}\left(1.944 \times 10^{-3} \mathrm{Btu} / \mathrm{h}-\mathrm{in}-{ }^{\circ} \mathrm{F}\right) \\
& \text { Specific heat }=795 \mathrm{~J} / \mathrm{kg}-{ }^{\circ} \mathrm{K}\left(0.19 \mathrm{Btu} / 1 \mathrm{bm}-{ }^{\circ} \mathrm{F}\right) \\
& \text { Density }=69.2 \mathrm{~kg} / \mathrm{m}^{3}\left(0.0025 \mathrm{lbm} / \mathrm{in}^{3}\right) .
\end{aligned}
$$

\subsubsection{Air}

Air exists between the DOT 208-L drum and the overpack and at the external surface of overpack. The thermo-physical properties of air are taken from Table B-5 (Irwin 1996). They are summarized below. 
Table B8-3. Material Properties of Air.

\begin{tabular}{|c|c|c|c|}
\hline $\begin{array}{l}\text { Temperature } \\
{ }^{\circ} \mathrm{C}\left({ }^{\circ} \mathrm{F}\right)\end{array}$ & $\begin{array}{l}\text { Thermal conductivity } \\
\mathrm{W} / \mathrm{m}^{-}{ }^{\circ} \mathrm{K}\left(\mathrm{Btu} / \mathrm{h} \mathrm{r}^{-} \mathrm{in} \mathrm{n}^{-}{ }^{\circ} \mathrm{F}\right)\end{array}$ & $\begin{array}{c}\text { Specific heat } \mathrm{J} / \mathrm{kg} \text { - } \\
\left.{ }^{\circ} \mathrm{K} \text { (btu/(bm) }{ }^{\circ} \mathrm{F}\right)\end{array}$ & $\begin{array}{c}\text { Q Qensity } \\
\mathrm{kg} / \mathrm{ms}^{3}\left(\mathrm{Lm} / \mathrm{in}^{3}\right)\end{array}$ \\
\hline$-17.8(0)$ & $0.023(1.11 E-03)$ & $1000(0.239)$ & $1.38(4.98$ E- 05$)$ \\
\hline $0(32)$ & $0.024(1.17 \mathrm{E}-03)$ & $1004(0.240)$ & $1.30(4.69 \mathrm{E}-05)$ \\
\hline $38(100)$ & $0.027(1.28 \quad E-03)$ & $1004(0.240)$ & $1.14(4.11 \mathrm{E}-05)$ \\
\hline $93(200)$ & $0.030(1.45 E-03)$ & $1008(0.241)$ & $0.96(3.47$ E- -05$)$ \\
\hline $149(300)$ & $0.033(1.61 E-03)$ & $1017(0.243)$ & $0.83(3.01$ E- 05$)$ \\
\hline $204(400)$ & $0.037(1.77 \mathrm{E}-03)$ & $1025(0.245)$ & $0.74(2.66$ E- 05$)$ \\
\hline $260(500)$ & $0.040(1.93 \mathrm{E}-03)$ & $1033(0.247)$ & $0.66(2.38$ E- 05$)$ \\
\hline $316(600)$ & $0.043(2.08 \mathrm{E}-03)$ & $1046(0.250)$ & $0.60(2.16 \mathrm{E}-05)$ \\
\hline $371(700)$ & $0.046(2.23 \mathrm{E}-03)$ & $1059(0.253)$ & $0.55(1.97$ E- 05$)$ \\
\hline $427(800)$ & $0.049(2.38 \mathrm{E}-03)$ & $1071(0.256)$ & $0.50(1.82 E-05)$ \\
\hline $482(900)$ & $0.052(2.53 \mathrm{E}-03)$ & $1084(0.259)$ & $0.47(1.68$ E- 05$)$ \\
\hline $538(1000)$ & $0.055(2.66 \mathrm{E}-03)$ & $1096(0.262)$ & $0.44(1.57 \mathrm{E}-05)$ \\
\hline $816(1500)$ & $0.069(3.33 E-03)$ & $1155(0.276)$ & $0.32(1.17$ E- 05$)$ \\
\hline
\end{tabular}

\subsubsection{Waste Contents}

The waste contents is assumed to have a specific density of 1.2 ; i.e., a density of $1190 \mathrm{~kg} / \mathrm{cm}^{3}\left(0.043 \mathrm{lbm} / \mathrm{in}^{3}\right)$. Other thermo-physical properties are adopted from Table A-46 for Hanford Tank C-106 waste at the temperature of $104{ }^{\circ} \mathrm{C}\left(220^{\circ} \mathrm{F}\right)$ (Irwin 1996).

Thermal conductivity $=0.674 \mathrm{~W} / \mathrm{m}-{ }^{\circ} \mathrm{K}\left(0.0325 \mathrm{Btu} / \mathrm{h}-\mathrm{in}-{ }^{\circ} \mathrm{F}\right)$

Specific heat $=1255 \mathrm{~J} / \mathrm{kg}-{ }^{\circ} \mathrm{K}\left(0.30 \mathrm{Btu} / 1 \mathrm{bm}-{ }^{\circ} \mathrm{F}\right)$

\subsection{THERMAL EVALUATION FOR NORMAL CONDITIONS}

The normal conditions that were evaluated were designed to measure the thermal performance of the containers under the high extreme of the Hanford climate and the low extreme of temperature specified in 10 CFR 71. Specifically these are:

- Ambient temperature of $46^{\circ} \mathrm{C}\left(115^{\circ} \mathrm{F}\right)$, no solar insolation.

- Ambient temperature of $46{ }^{\circ} \mathrm{C}\left(115^{\circ} \mathrm{F}\right)$, worst-case Hanford Site solar insolation.

- Ambient temperature of $-40^{\circ} \mathrm{C}\left(-40^{\circ} \mathrm{F}\right)$, no solar insolation. 
HNF-SD-TP-SARP-023 Rev. 0

\subsubsection{Acceptance Criteria}

The Doorstop Sample Carrier System must, under normal conditions, show no appreciable degradation of shielding, containment, or structural properties. Additionally, under maximum ambient temperature of $46{ }^{\circ} \mathrm{C}\left(115{ }^{\circ} \mathrm{F}\right)$ without solar insolation, the maximum accessible surface temperature of the cask with overpack must be less than $82{ }^{\circ} \mathrm{C}\left(180^{\circ} \mathrm{F}\right)$.

\subsubsection{Thermal Model for Normal Conditions}

ANSYS general finite element computer program (SAS 1995) is used to develop the thermal model for both normal and accident conditions. A two-dimensional model with a quarter section of the double-overpack configuration is used here. The general picture is shown in Figure B8-1 and the zoom-in views of right-hand side and left hand-side with node numbers are shown in Figure B8-2 and B8-3.

Figure B8-1. General View of Thermal Evaluation Finite Element Model.

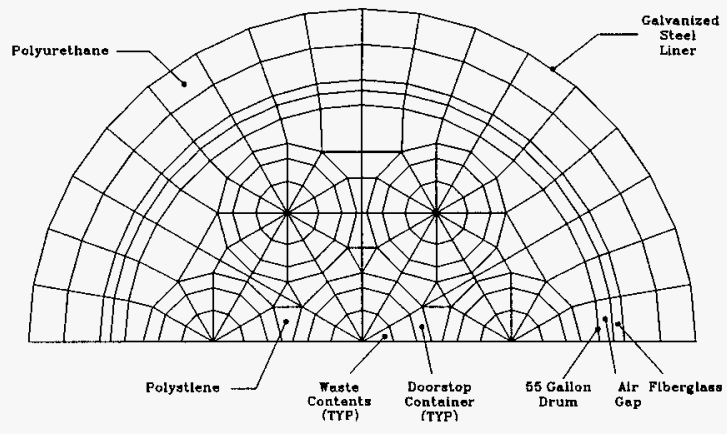


Figure B8-2. Finite Element Model with Node Numbers (Right Side).
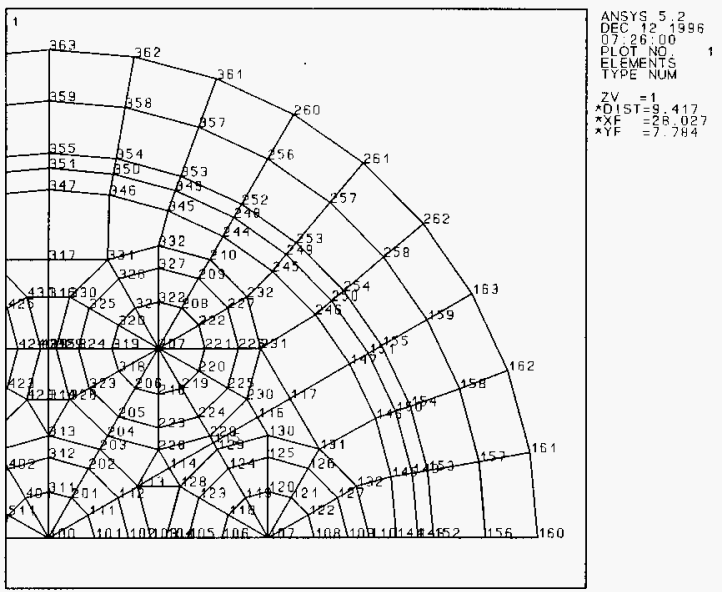

Figure B8-3. Right Side Zoom of Nodes.

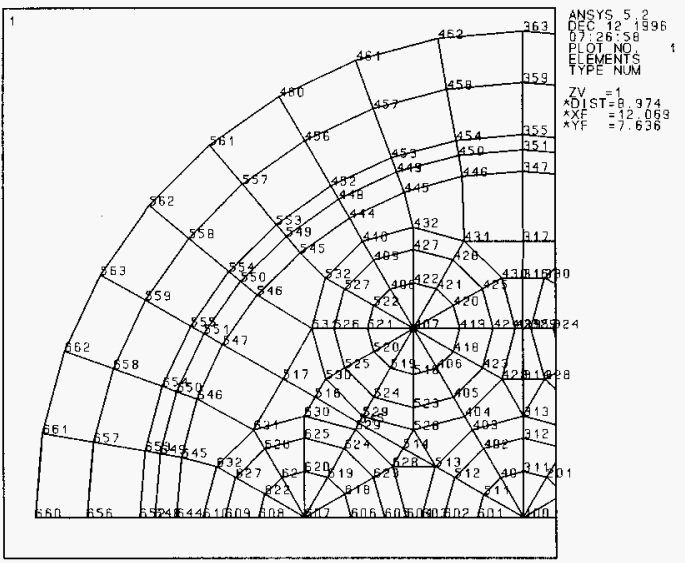


ANSYS element PLANE55, two-dimensional heat conduction solid element, is used for the Doorstop container, waste contents, and insulations (polystyrene, polyurethane, and fiberglass). The 55-gallon drum is modeled with surface element SURF19. The SURF19 element in two-dimensions is a line element connecting two nodes. A third node is identified where heat transfer occurs. This surface element can be used to account for heat transfer through thermal convection and thermal radiation. In this case, however, heat is only transferred via thermal radiation in the air gap between the DOT 208-L drum and the overpack's fiberglass layer. In addition, heat conduction links (LINK32) are used at the air gap for thermal conduction heat transfer.

The galvanized steel liner, also modelled as surface elements (SURF19), has both convection and radiation options activated. The galvanized steel liner is influenced by two objects. One object is the environment which provides natural thermal convection and thermal radiation. The second object is the adjacent overpack which also provides the thermal convection and thermal radiation. Consequently, the galvanized steel surface that faces the second overpack has two surface elements. One surface has heat transfers between the overpack and the environment, and the other surface has heat transfers between the two overpacks.

The emissivity factor of both carbon steel and fiberglass is 0.9 . The material form factor of carbon to fiberglass is 0.92 , refer to Table 4 (Irwin 1996). The emissivity of the galvanized steel liner is also assumed to be 0.9. The form factors between the overpack and the environment is also 0.82. For the surface that faces the second overpack the form factors varies from 0 to 0.82 depending on the angles of two overpack surfaces. However, the total sum of form factors of both surface elements (to environment and the second overpack) is still 0.82 .

The natural convection heat transfer coefficient equation of the external surface of overpack to the environment is taken from Appendix B of the Thermal Analysis Methods for Safety Analysis Reports for Packaging (Irwin 1996).

$$
h=\left(\frac{k}{L}\right) 0.555 R a^{0.25}
$$

where: $\mathrm{Ra}=$ Rayleigh number

$\mathrm{k}=$ air thermal conductivity

$L=$ plate length

The temperature dependent convection heat transfer coefficients are listed in tables below. 
HNF-SD-TP-SARP-023 Rev. 0

Table B8-4. Convection Heat Transfer Coefficient of Air Ambient Temperature at $46^{\circ} \mathrm{C}\left(115^{\circ} \mathrm{F}\right)$.

\begin{tabular}{|c|c||c|c|}
\hline $\begin{array}{c}\text { Temperature } \\
{ }^{\circ} \mathrm{C}\left({ }^{\circ} \mathrm{F}\right)\end{array}$ & $\begin{array}{c}\text { Convection heat } \\
\text { transfer coefficient } \\
W / \mathrm{m}^{2}-{ }^{\circ} \mathrm{K}\left(\mathrm{BtU} / \mathrm{h}-\mathrm{in}{ }^{\circ} \mathrm{F}\right)\end{array}$ & $\begin{array}{c}\text { Temperature } \\
{ }^{\circ} \mathrm{C}\left({ }^{\circ} \mathrm{F}\right)\end{array}$ & $\begin{array}{c}\text { Convection heat } \\
\text { transfer coefficjent } \\
\text { W/m }-{ }^{\circ} \mathrm{K}\left(\mathrm{Btu} / \mathrm{h}-\mathrm{in}{ }^{2}-{ }^{\circ} \mathrm{F}\right)\end{array}$ \\
\hline $46(115)$ & $0.8(1.00 \mathrm{E}-03)$ & $371(700)$ & $4.4(5.33 \mathrm{E}-03)$ \\
\hline $93(200)$ & $3.3(4.03 \mathrm{E}-03)$ & $427(800)$ & $4.5(5.44 \mathrm{E}-03)$ \\
\hline $149(300)$ & $3.8(4.60 \mathrm{E}-03)$ & $482(900)$ & $4.5(5.52 \mathrm{E}-03)$ \\
\hline $204(400)$ & $4.0(4.87 \mathrm{E}-03)$ & $538(1000)$ & $4.6(5.56 \mathrm{E}-03)$ \\
\hline $260(500)$ & $4.1(5.06 \mathrm{E}-03)$ & $816(1500)$ & $4.7(5.73 \mathrm{E}-03)$ \\
\hline $316(600)$ & $4.3(5.25 \mathrm{E}-03)$ & & \\
\hline
\end{tabular}

Table B8-5. Convection Heat Transfer Coefficient of Air Ambient Temperature at $-40^{\circ} \mathrm{C}\left(-40^{\circ} \mathrm{F}\right)$.

\begin{tabular}{|c|c||c|c|}
\hline $\begin{array}{c}\text { Temperature } \\
{ }^{\circ} \mathrm{C}\left({ }^{\circ} \mathrm{F}\right)\end{array}$ & $\begin{array}{c}\text { Convection Heat } \\
\text { Transfer Coefficjent } \\
W / \mathrm{m}^{2} \cdot{ }^{\circ} \mathrm{K}\left(\mathrm{Btu} / \mathrm{h}-\mathrm{in}{ }^{\circ} \mathrm{O}\right)\end{array}$ & $\begin{array}{c}\text { Temperature } \\
{ }^{\circ} \mathrm{C}\left({ }^{\circ} \mathrm{F}\right)\end{array}$ & $\begin{array}{c}\text { Convection Heat } \\
\text { Transfer Coefficjent } \\
\mathrm{H}^{2}-\mathrm{m}^{\circ} \mathrm{K}\left(\mathrm{Btu} / \mathrm{h}-\mathrm{in}^{2}-{ }^{\circ} \mathrm{F}\right)\end{array}$ \\
\hline$-17.8(0)$ & $3.1(3.81 \mathrm{E}-03)$ & $316(600)$ & $4.6(5.63 \mathrm{E}-03)$ \\
\hline $0(32)$ & $3.5(4.32 \mathrm{E}-03)$ & $371(700)$ & $4.6(5.66 \mathrm{E}-03)$ \\
\hline $38(100)$ & $4.0(4.84 \mathrm{E}-03)$ & $427(800)$ & $4.7(5.73 \mathrm{E}-03)$ \\
\hline $93(200)$ & $4.3(5.22 \mathrm{E}-03)$ & $482(900)$ & $4.7(5.77 \mathrm{E}-03)$ \\
\hline $149(300)$ & $4.4(5.35 \mathrm{E}-03)$ & $538(1000)$ & $4.7(5.79 \mathrm{E}-03)$ \\
\hline $204(400)$ & $4.4(5.43 \mathrm{E}-03)$ & $816(1500)$ & $4.8(5.88 \mathrm{E}-03)$ \\
\hline $260(500)$ & $4.5(5.51 \mathrm{E}-03)$ & & \\
\hline
\end{tabular}

The input file of the thermal model for the first normal condition case (ambient temperature of $46^{\circ} \mathrm{C}\left[115^{\circ} \mathrm{F}\right]$, no solar insolation) is shown in Appendix $A$. The Case 3 (ambient temperature of $-40^{\circ} \mathrm{C}\left[-40^{\circ} \mathrm{F}\right]$, no solar insolation) replaces the ambient temperature from $46{ }^{\circ} \mathrm{C}\left(115^{\circ} \mathrm{F}\right)$ to $-40^{\circ} \mathrm{C}$ $\left(-40^{\circ} \mathrm{F}\right)$ and changes the convection heat transfer coefficient of air from Table B8-4 to B8-5. For the Case 2 (ambient temperature of $46{ }^{\circ} \mathrm{C}\left[115^{\circ} \mathrm{F}\right]$, worst case Hanford Site solar insolation), the input file of Case 1 replaces the heat convection input by the heat flux input in the definition of the elements and activate the Hanford solar insolation rate as described earlier. The required replacements are documented in Table B8-6. 
Table B8-6. Case 2 Replacement.

\begin{tabular}{|c|c|}
\hline Category & Case 2 Replacement \\
\hline Title & $\begin{array}{l}\text { /title, 2-d door stop container steady state } \\
\text { analysis--Hanford insolation }\end{array}$ \\
\hline $\begin{array}{l}\text { Define solar } \\
\text { insolation }\end{array}$ & solar $=0.5 * 1.3808 * 0.8 *$ abs $=0.8$ \\
\hline $\begin{array}{l}\text { Element } \\
\text { definition }\end{array}$ & 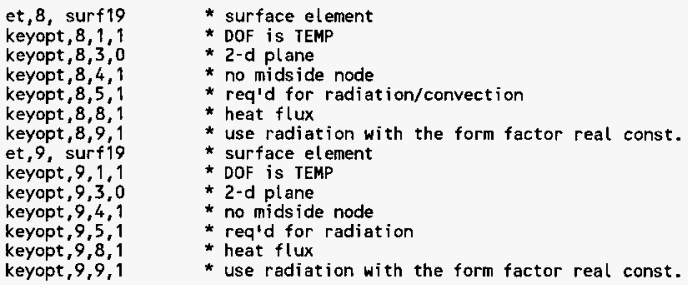 \\
\hline $\begin{array}{l}\text { Heat } F \text { lux } \\
\text { Definition }\end{array}$ & $\begin{array}{l}c^{\star * *} \text { solar heat flux at overpack external } \\
\text { esel, s, mat, ,8 } \\
\text { sfe, al i, } 1, \text { hflux, solar } \\
\text { esel, all }\end{array}$ \\
\hline
\end{tabular}

\subsubsection{Thermal Analysis Results for Normal Conditions}

The results for normal conditions are summarized in Table B8-7 and shown in Figure B8-4 through Figure B8-6.

Table B8-7. Normal Condition Thermal Analysis Results

Maximum Temperature Except Indicated by Min.

\begin{tabular}{|c|c|c|c|}
\hline Case & ${ }^{\circ}$ & ${ }^{\circ}\left({ }^{\circ} \mathrm{F}\right)$ & ${ }^{2}$ \\
\hline \hline Seal of Doorstop container & $114(237)$ & $139(282)$ & $37(98)$ \\
\hline External surface of overpack & $69(156)$ & $101(213)$ & $-33(-28)(\mathrm{min})$ \\
\hline Internal surface of overpack & $107(225)$ & $132(269)$ & $2(35)(\mathrm{min})$ \\
\hline Outside surface of inner pack & $111(231)$ & $134(274)$ & $26(78)(\mathrm{min})$ \\
\hline
\end{tabular}


Figure B8-4. Temperature Distribution of Normal Condition Case 1.

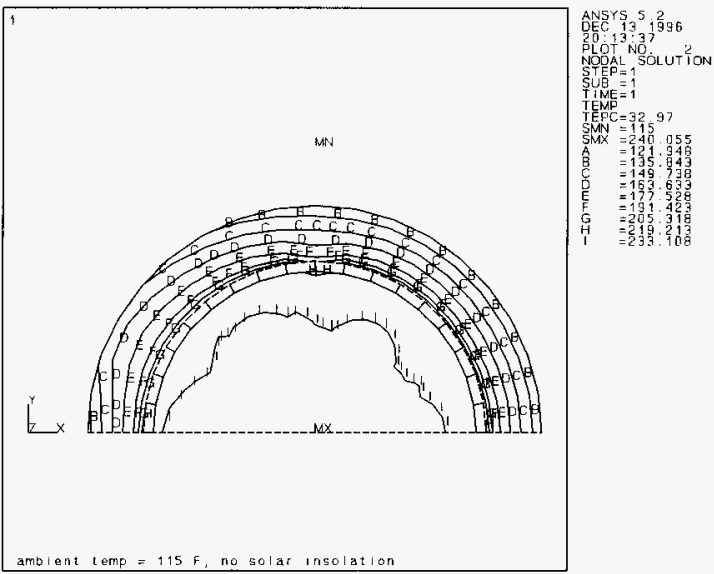

Figure B8-5. Temperature Distribution for Norma1 Condition Case 2.

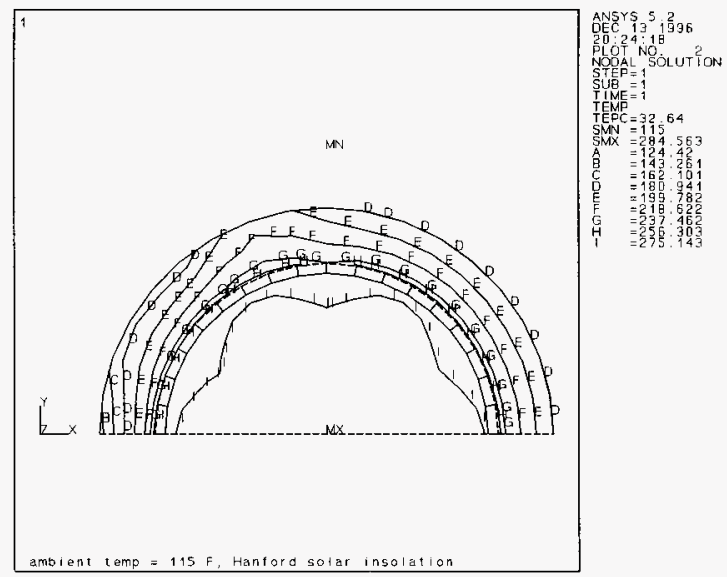


Figure B8-6. Temperature Distribution for Normal Condition Case 3 .

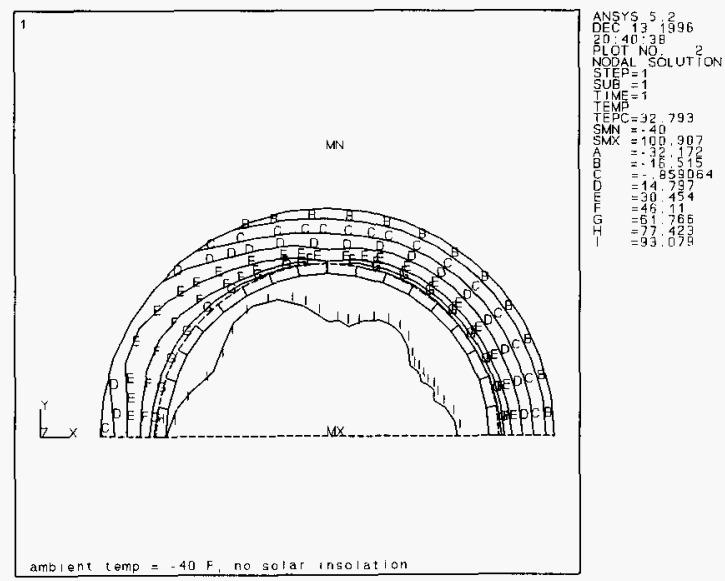

\subsection{THERMAL EVALUATION FOR ACCIDENT CONDITIONS}

Prior to the fire accident, the Doorstop Sample Carrier System is assumed to be at steady state in a $46^{\circ} \mathrm{C}\left(115^{\circ} \mathrm{F}\right)$ ambient temperature environment without solar insolation. These same conditions are assumed present subsequent to the fire event. The fire accident event will have a temperature of $800{ }^{\circ} \mathrm{C}\left(1475{ }^{\circ} \mathrm{F}\right)$ for a duration of 30 minutes. The effective emissivity of the fire for determining the heat transferred via radiation is 0.9 as specified in I0 CFR 71.73. The form factor of 0.82 is used in this analysis. This factor is based on the emissivity of 0.9 for the galvanized steel 1 iner and the assumed totally engulfing fire.

\subsubsection{Acceptance Criteria}

The package shall not show any appreciable degradation of shielding, containment, or structural properties during and after a fire accident event.

\subsubsection{Thermal Model for Accident Conditions}

The thermal model for accident conditions is 1 isted in Part $B$, Section 8.6.3. The thermal model for normal conditions is used by addition of the convection heat transfer coefficient for ambient temperature at $800{ }^{\circ} \mathrm{C}$ $\left(1475^{\circ} \mathrm{F}\right)$ as in Table B8-8, which is used during the 30-minute fire. Also the transient thermal load steps are added to simulate the fire event. 
Table B8-8. Convection Heat Transfer Coefficient of Air Ambient Temperature at $800^{\circ} \mathrm{C}\left(1475^{\circ} \mathrm{F}\right)$.

\begin{tabular}{|c|c|c|c|}
\hline $\begin{array}{l}\text { Temperature } \\
{ }^{\circ} \mathrm{C}\left({ }^{\circ} \mathrm{F}\right)\end{array}$ & $\begin{array}{c}\text { Convection Heat } \\
\text { Transfer Coefficient } \\
W / m^{2}-{ }^{\circ} \mathrm{K}\left(\mathrm{Btu} / \mathrm{h}-\mathrm{in}^{2}-{ }^{\circ} \mathrm{F}\right)\end{array}$ & $\begin{array}{l}\text { Temperature } \\
{ }^{\circ} \mathrm{C}\left({ }^{\circ} \mathrm{F}\right)\end{array}$ & $\begin{array}{c}\text { Convection Heat } \\
\text { Iransfer Coefficient } \\
\text { W/m } \mathrm{m}^{2}-{ }^{\circ} \mathrm{K}\left(\mathrm{Btu} / \mathrm{h}-\mathrm{in}^{2}-{ }^{\circ} \mathrm{F}\right) \\
\end{array}$ \\
\hline $38(100)$ & 7.0 (8.57 E-03) & $371(700)$ & $4.7(5.72 \varepsilon-03)$ \\
\hline $93(200)$ & $6.5(7.93 E-03)$ & $427(800)$ & $4.4(5.42 E-03)$ \\
\hline $149(300)$ & $6.0(7.30 \mathrm{E}-03)$ & $482(900)$ & $4.2(5.10(E-03)$ \\
\hline $204(400)$ & $5.6(6.79$ E- 03$)$ & $538(1000)$ & $3.9(4.76 E-03)$ \\
\hline $260(500)$ & $5.2(6.39 \mathrm{E}-03)$ & $816(1500)$ & $1.7(2.10 E-03)$ \\
\hline $316(600)$ & $5.0(6.08 \mathrm{E}-03)$ & & \\
\hline
\end{tabular}

\subsubsection{Thermal Analysis Results for Accident Condition}

The temperature distributions of the fire accident are depicted in Figures $88-7$ through $\mathrm{B} 8-14$ for at the initial steady state, heatup to $800{ }^{\circ} \mathrm{C}$ $\left(1475{ }^{\circ} \mathrm{F}\right), 10$ minutes at $800^{\circ} \mathrm{C}\left(1475{ }^{\circ} \mathrm{F}\right), 20$ minutes at ${ }^{\circ} \mathrm{F}, 30$ minutes at $800{ }^{\circ} \mathrm{C}\left(1475{ }^{\circ} \mathrm{F}\right)$, cooldown to $46^{\circ} \mathrm{C}\left(115^{\circ} \mathrm{F}\right)$ after fire, 30 minutes after fire, and 200 hours after fire, respectively. These are the snap shots of temperature during the fire. The maximum temperature history at the neoprene seal of Doorstop container (Node 602) is shown in Figure B8-15. Similarly, the maximum temperature histories at the external surface of overpack (Node 160), at the internal surface of overpack (Node 351 ), and at the outside surface of the inner pack (Node 347) are shown in Figures B8-16, B8-17, and B8-18, respectively. The maximum temperatures during the fire accident at the critical locations are identified in Table B8-9. 
HNF-SD-TP-SARP-023 Rev. 0

Figure B8-7. Temperature Distribution for Accident Condition, Initial Steady State.

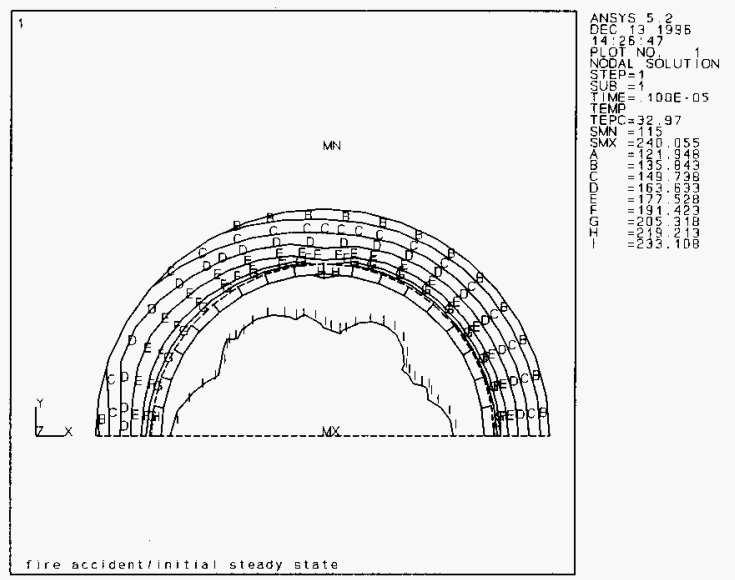

Figure B8-8. Temperature Distribution for Accident Condition, Heat up to $800{ }^{\circ} \mathrm{C}\left(1475{ }^{\circ} \mathrm{F}\right)$.

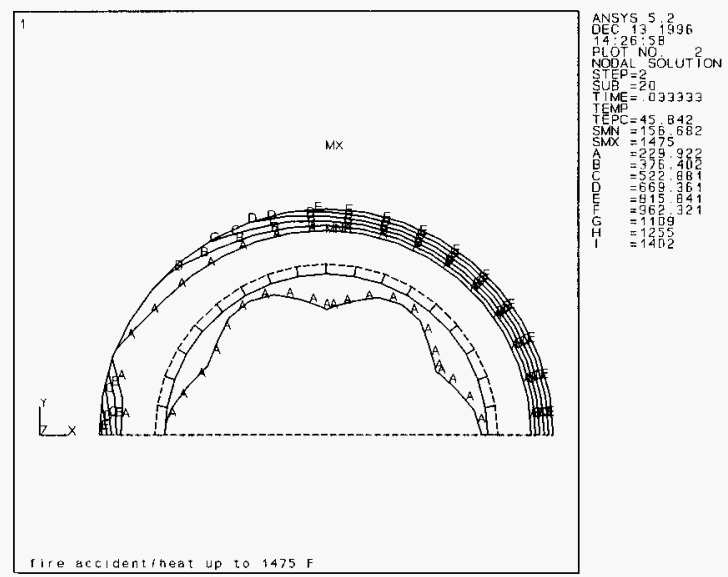


HNF-SD-TP-SARP-023 Rev. 0

Figure B8-9. Temperature Distribution for Accident Condition, 10 minutes at $800^{\circ} \mathrm{C}\left(1475{ }^{\circ} \mathrm{F}\right)$.

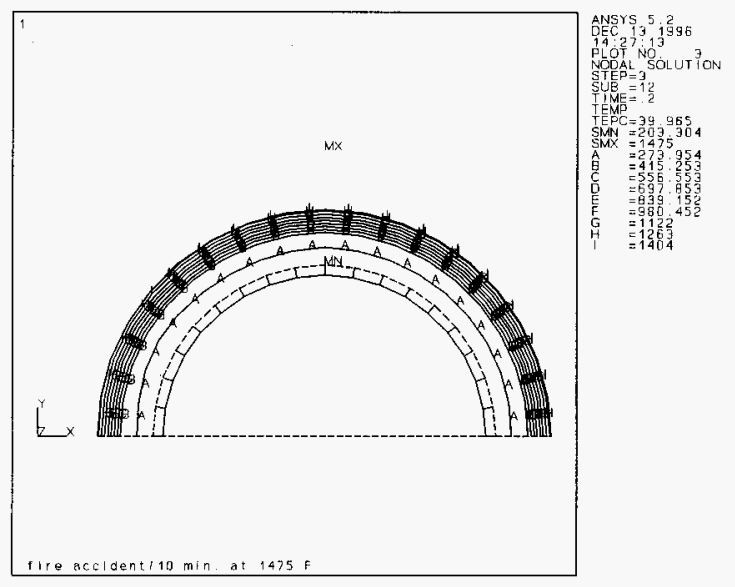

Figure B8-10. Temperature Distribution Accident Condition, 20 minutes at $800^{\circ} \mathrm{C}\left(1475{ }^{\circ} \mathrm{F}\right)$.

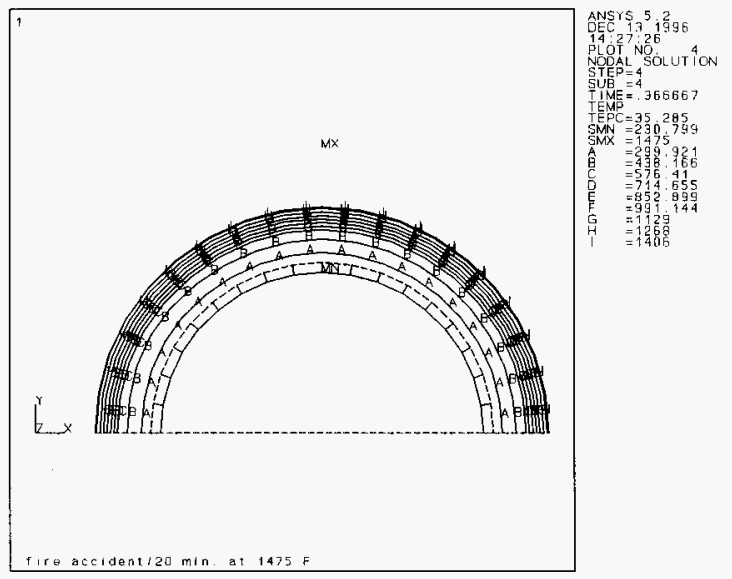

B8-14 
HNF-SD-TP-SARP-023 Rev. 0

Figure B8-11. Temperature Distribution for Accident Condition, 30 minutes at $800^{\circ} \mathrm{C}\left(1475^{\circ} \mathrm{F}\right)$.
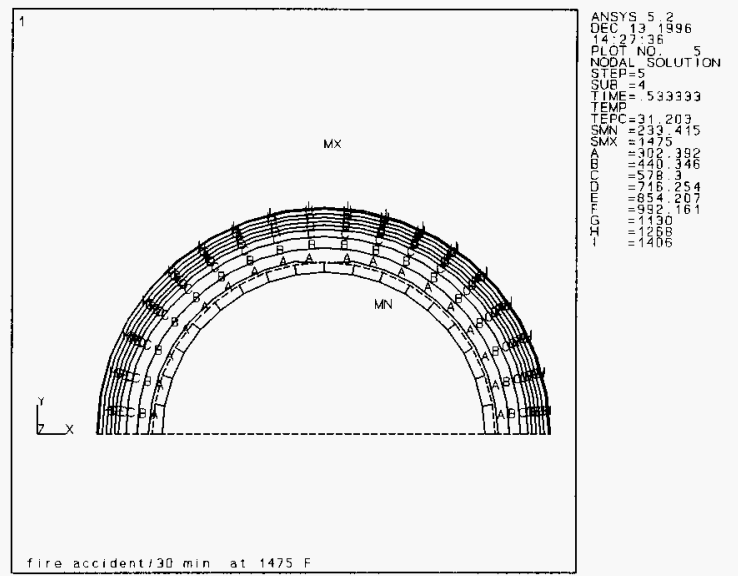

Figure B8-12. Temperature Distribution for Accident Conditions, Cool Down to $46^{\circ} \mathrm{C}\left(115^{\circ} \mathrm{F}\right)$.
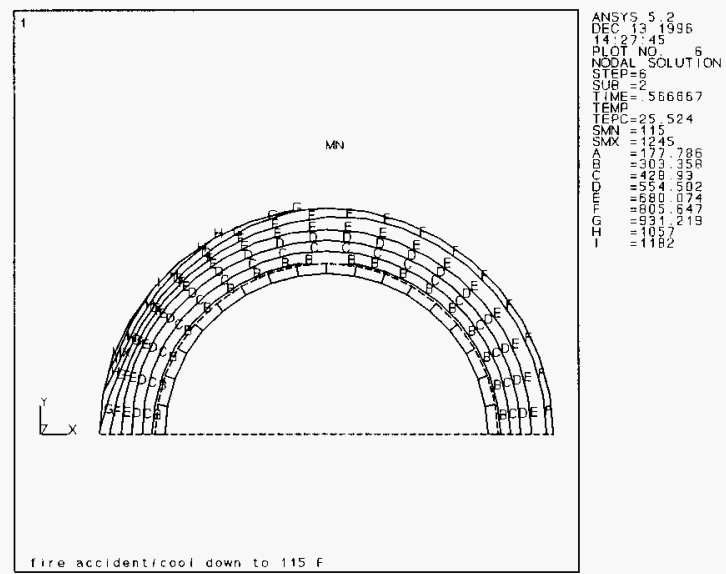


\section{HNF-SD-TP-SARP-023 ReV. 0}

Figure B8-13. Temperature Distribution for Accident Condition, 30 minutes at $46^{\circ} \mathrm{C}\left(115^{\circ} \mathrm{F}\right)$ after Fire Event.
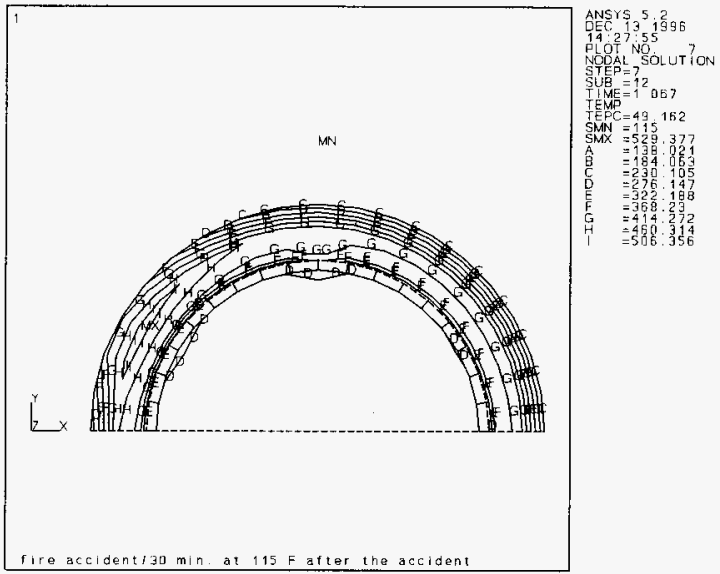

Figure B8-14. Temperature Distribution for Accident Condition, $200 \mathrm{~h}$ at $46^{\circ} \mathrm{C}\left(115^{\circ} \mathrm{F}\right)$ after the Fire Event.
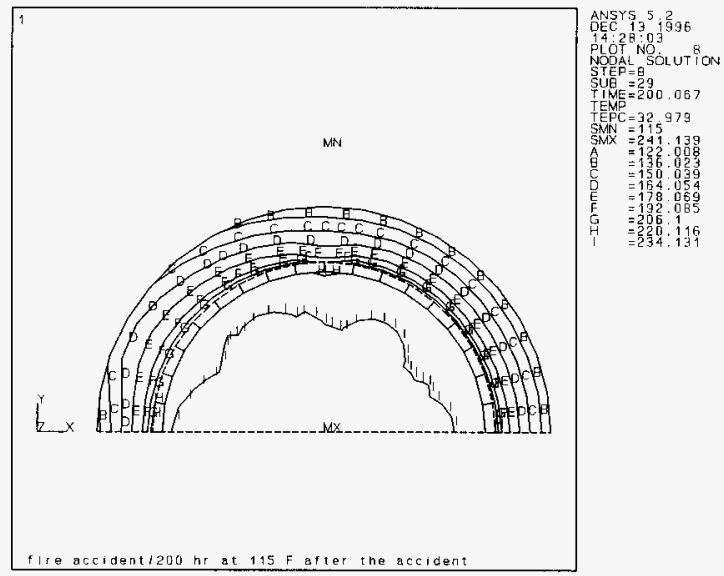
Figure B8-15. Maximum Temperature History at the Container Seal.

Temparature (F)

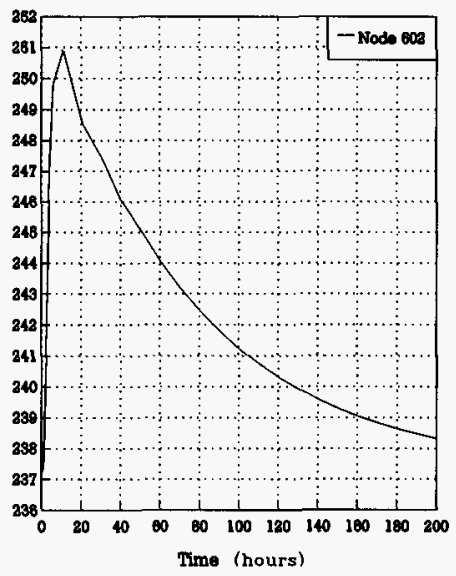

Figure B8-16. Maximum Temperature History at Exterior Wa11 of Overpack.

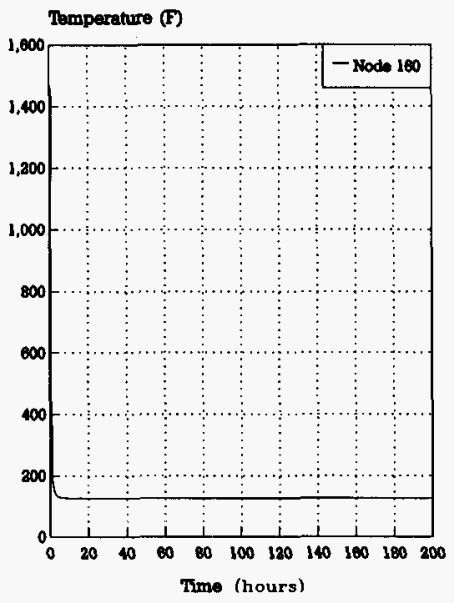


HNF-SD-TP-SARP-023 Rev. 0

Figure B8-17. Maximum Temperature History at Interior Wall of Overpack.

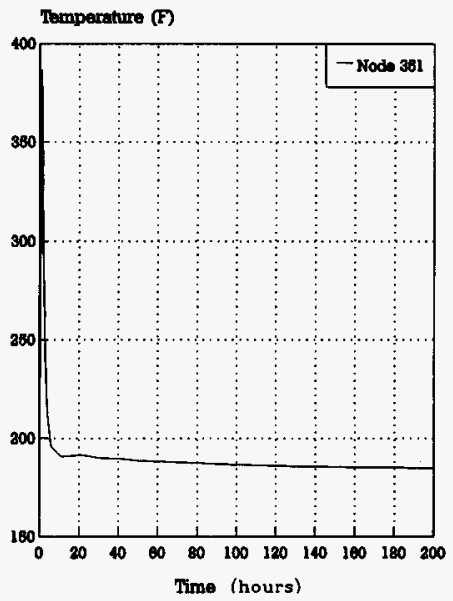

Figure B8-18. Maximum Temperature History at Exterior Wall of Inner Pack.

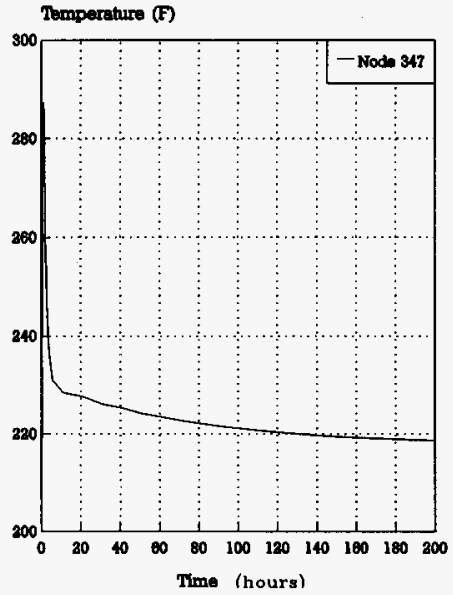




$$
\text { HNF-SD-TP-SARP-023 Rev. } 0
$$

Table B8-9. Fire Accident Thermal Analysis Results.

\begin{tabular}{|c|c|}
\hline Case & $\begin{array}{l}\text { Fire Accident } \\
{ }^{\circ} \mathrm{C}\left({ }^{\circ} \mathrm{F}\right)\end{array}$ \\
\hline Seal of Doorstop container & $122(251)$ \\
\hline External surface of overpack & $797(1467)$ \\
\hline Internal surface of overpack & $197(387)$ \\
\hline Dutside surface of inner pack & $142(287)$ \\
\hline
\end{tabular}

\subsection{THERMAL EVALUATION CONCLUSION}

The Neoprene service temperature ranges from $-54{ }^{\circ} \mathrm{C}\left(-65{ }^{\circ} \mathrm{F}\right)$ to $149{ }^{\circ} \mathrm{C}$ $\left(300{ }^{\circ} \mathrm{F}\right)$. The minimum temperature of the seal is $37^{\circ} \mathrm{C}\left(98^{\circ} \mathrm{F}\right)$ for the normal condition of ambient temperature of $-40^{\circ} \mathrm{C}\left(-40^{\circ} \mathrm{F}\right)$. The maximum temperature at the Neoprene seal is $139{ }^{\circ} \mathrm{C}\left(282{ }^{\circ} \mathrm{F}\right)$ for the normal condition under the Hanford solar insolation. The maximum temperature of the seal under the fire condition is $122{ }^{\circ} \mathrm{C}\left(251{ }^{\circ} \mathrm{F}\right)$. The temperature of the seal for this package is higher under the normal conditions than in the fire case. The reason for this is that, under normal conditions, worst-case Hanford Site solar insolation is applied. Under onsite accident conditions, no solar insolation is applied to the package during the fire event. The basis for this is 10 CFR 71.73 which states that solar radiation may be neglected in a fire event. Consequently, the seal of the Doorstop container is adequate to sustain the specified onsite normal conditions and accident conditions. The external surface temperature is below $82{ }^{\circ} \mathrm{C}\left(180{ }^{\circ} \mathrm{F}\right)$ for the normal condition with ambient temperature of $46{ }^{\circ} \mathrm{C}\left(115^{\circ} \mathrm{F}\right)$ and with no solar insolation. Consequently, package does not need to be shipped as an exclusive use shipment.

\subsection{REFERENCES}

10 CFR 71, 1995, "Packaging and Transportation of Radioactive Materials", Code of Federal Regulations, as amended.

Irwin, J. J., 1996, Thermal Analysis Methods for Safety Analysis Reports for Packaging, WHC-SD-TP-RPT-005, Rev. 1, Westinghouse Hanford Company, Richl and, Washington.

Penton Publishing Inc., 1988, "Material Reference Issue," Machine Design, Penton Publishing Inc., Cleveland, Ohio.

RH0, 1984, Doorstop Container, drawing H-2-73008, Rev. M, Rockwel1 Hanford Operations, Richland, Washington.

RH0, 1983, Transport Container Tie Down and Frame Assembly, drawing H-2-73010, Rev. M, Rockwell Hanford Operations, Richland, Washington.

RHO, 1978, Transport Container Sub-Assemblies, drawing H-2-73033, Rockwell Hanford Operations, Richland, Washington. 
HNF-SD-TP-SARP-023 Rev. 0

SAS, 1995, ANSYS User's Manual for Revision 5.2, Swanson Analysis Systems, Inc., Houston, Pennsylvania.

NuPac, 1987, NuPac Mode7 N-55 Type 3 Overpack, drawing X-60-2000-SNP, Nuclear Packaging, Inc., Seattle, Washington. 
HNF-SD-TP-SARP-023 Rev. 0

\subsection{APPENDICES}

\subsubsection{Thermal Evaluation Model for Normal Condition}

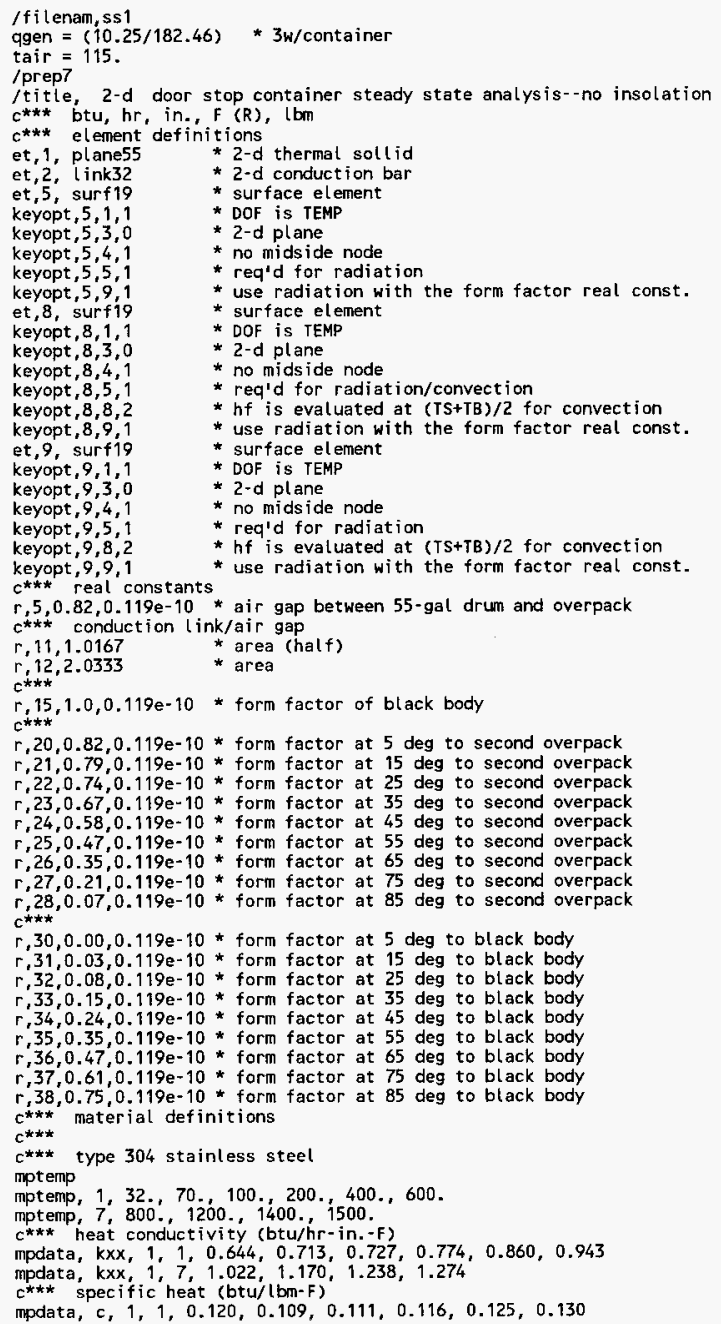




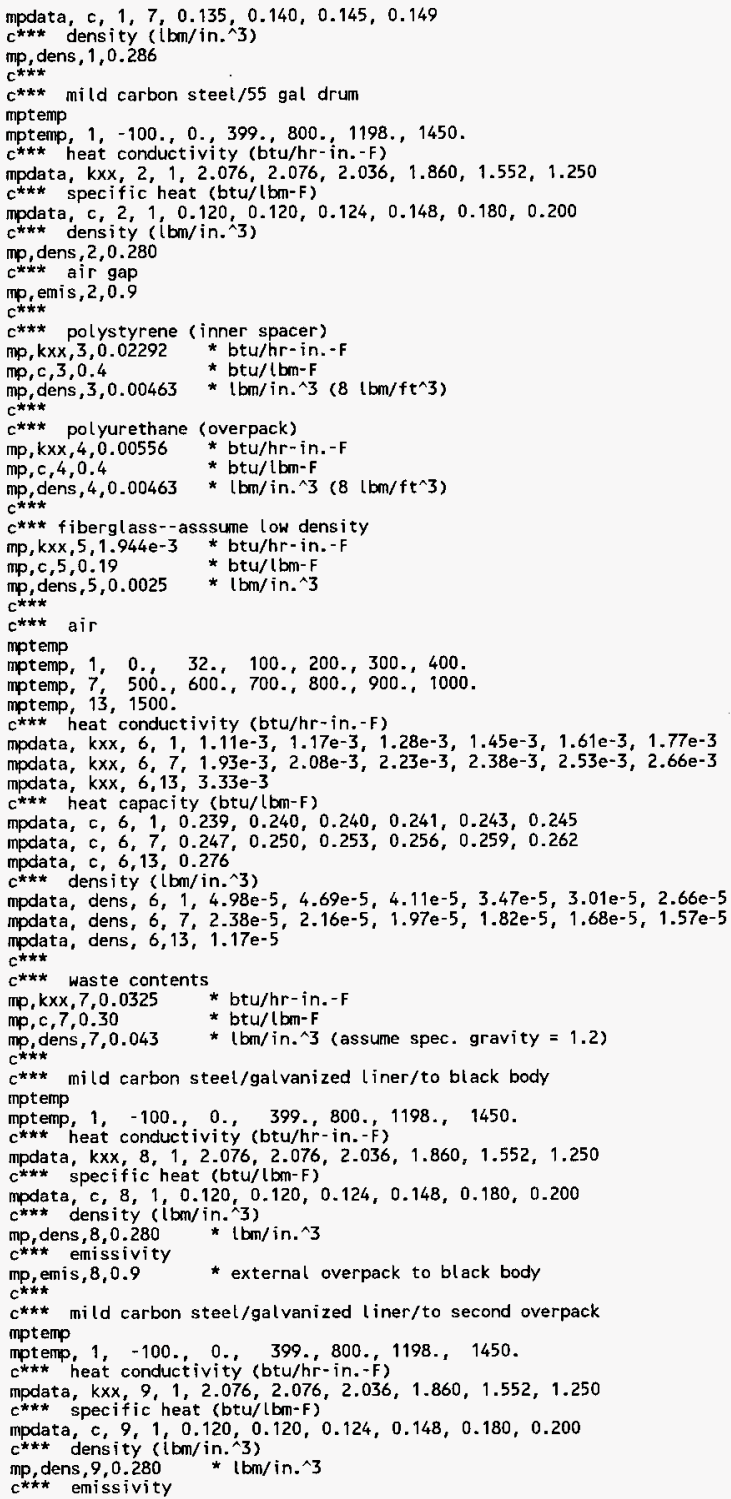




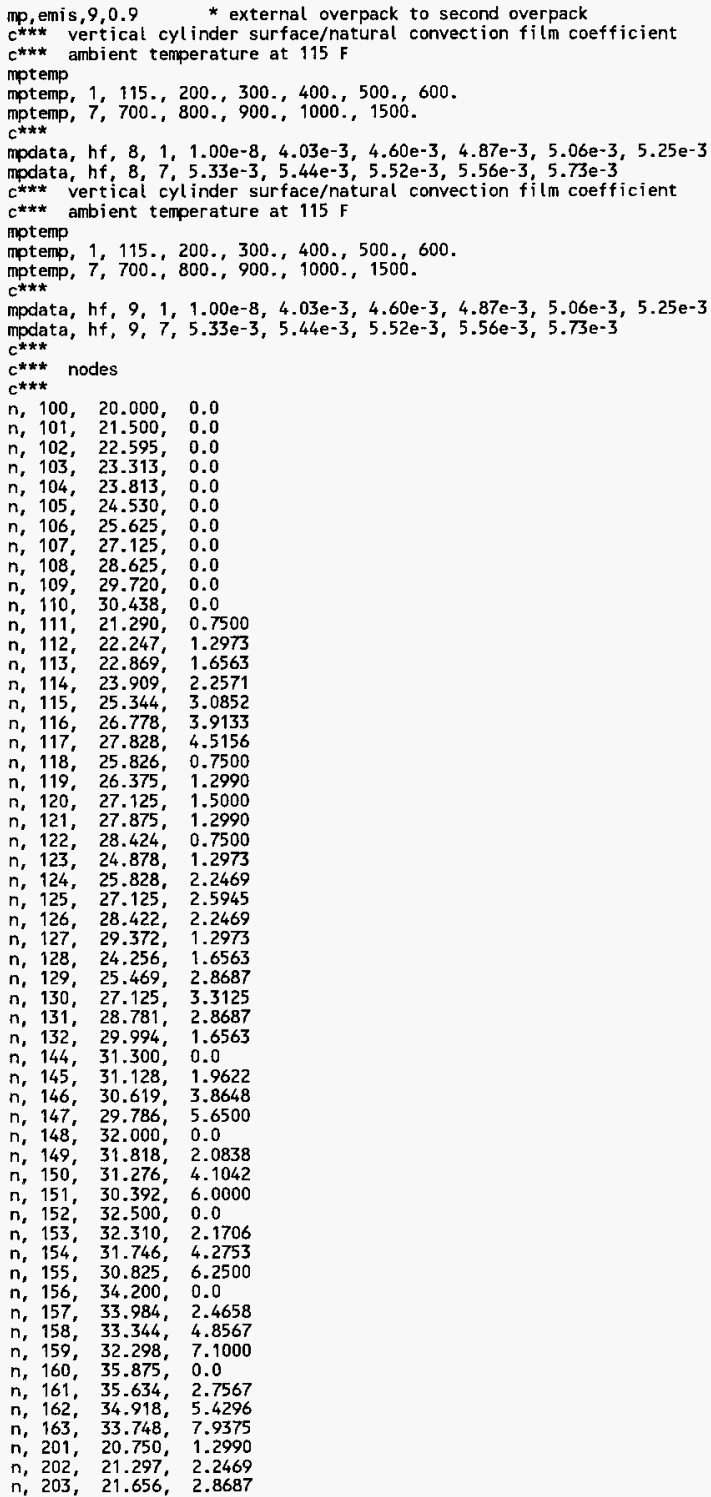


HNF-SD-TP-SARP-023 Rev. 0
$n, 204,21.906,3.3017$
$n, 205, \quad 22.265, \quad 3.9235$
$n, 206,22.812,4.8714$
n, 207, 23.562, 6.1704
$n, 208,24.312,7.4695$
$n, 209,24.860,8.4173$
$n, 210,25.219,9.0391$
$n, 218,23.563,4.6705$
$n, 219,24.312,4.8794$
$n, 220,24.862,5.4204$
$n, 221,25.062,6.1705$
$n, 222,24.862,6.9204$
$n, 223,23.563,3.5759$
$n, 224,24.860,3.9236$
$n, 225,25.809,4.8732$
n, 226, 26.157, 6.1705
$n, 227,25.809,7.4677$
$n, 228,23.563,2.8579$
n, 229, 25.219, 3.3018
$\mathrm{n}, 230,26.431,4.5142$
$n, 231,26.875,6.1705$
$n, 232,26.431,7.8266$
$n, 244,25.650,9.7861$
$n, 245,27.263,8.6563$
$n, 246,28.656,7.2635$
$n, 248,26.000,10.392$
$n, 249,27.713,9.1925$
$n, 250,29.192, \quad 7.7135$
$n, 252,26.250,10.825$
$n, 253,28.035,9.5756$
$n, 254,29.576,8.0349$
$n, 255,30.825,6.2500$
$n, 256,27.100,12.298$
$n, 257,29.128,10.878$
n, 258, 30.878, 9.1275
$n, 259, \quad 32.298,7.1000$
$n, 260,27.937,13.748$
$n, 261,30.204,12.161$
$\mathrm{n}, 262,32.161,10.204$
$n, 311,19.995,1.4922$
$n, 312,20.000,2.5945$
$n, 313,20.000,3.3125$
$n, 314,20.000,4.5142$
$n, 315,20.000,6.1705$
$\mathrm{n}, 316,20.000,7.8267$
$\mathrm{n}, 317,20.003,9.0371$
$\mathrm{n}, 318,22.263, \quad 5.4205$
$n, 319,22.063,6.1704$
$\mathrm{n}, 320,22.263,6.9204$
$n, 321,22.813,7.4695$
n, 322, 23.562, 7.6704
n, 323, 21.316, 4.8732
n, 324, 20.968, 6.1705
n, 325, 21.316, 7.4677
$n, 326,22.265,8.4174$
$n, 327,23.562,8.7650$
$n, 328,20.694,4.5142$
$n, 329,20.250,6.1705$
$\mathrm{n}, 330,20.694,7.8267$
$n, 331,21.906,9.0392$
$n, 332,23.562,9.4829$
n, 344, 25.650, 9.7861
n, 345, 23.865, 10.618
$n, 346,21.962,11.128$
$n, 347,20.000,11.300$
n, 348, 26.000, 10.392
$n, 349,24.104, \quad 11.276$
$\mathrm{n}, 350,22.084,11.818$
$\mathrm{n}, 351,20.000,12.000$
$n, 353,24.275,11.746$
n, 354, 22.171, 12.310
n, 355, 20.000, 12.500
n, 357, 24.857, 13.344
n, 358, 22.466, 13.984
$n, 359,20.000,14.200$
n, 361, 25.430, 14.918 
HNF-SD-TP-SARP-023 Rev. 0

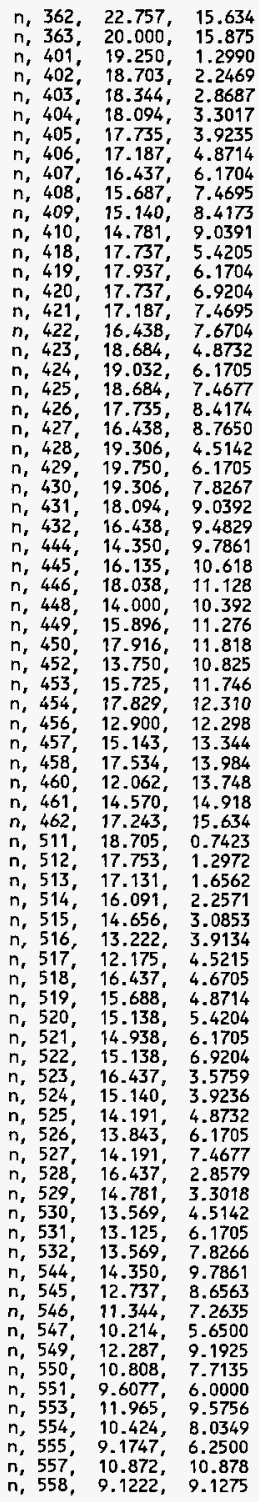




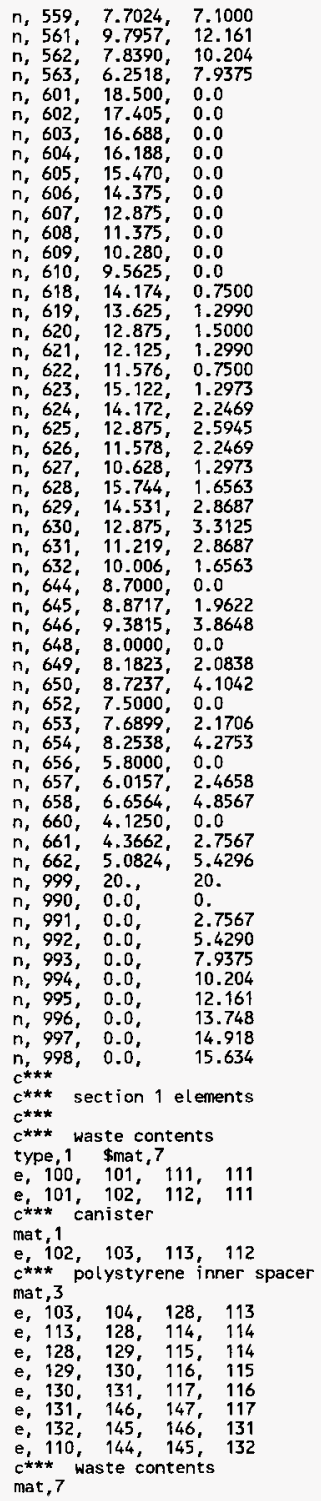




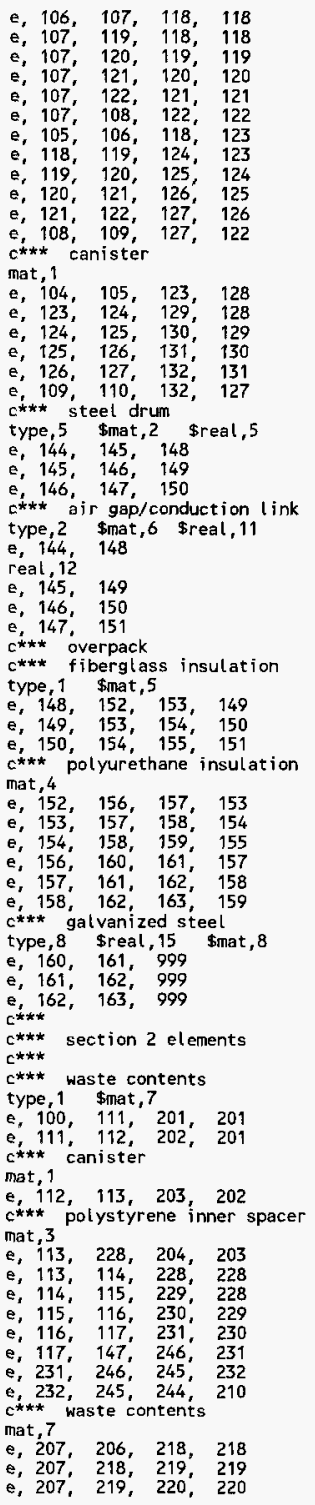


e, 207, 220, 221, 221
e, 207, 221, 222, 222
e, 207, 222, 208, 208
e, 205, 223, 218, 206
e, 223, 224, 219, 218
e, 224, 225, 220, 219
e, 225, 226, 221, 220
e, 226, 227, 222, 221
e, 227, 209, 208, 222
c** canister
mat 1

e, 204, 228, 223, 205

e, 228, 229, 224, 223

e, 229, 230, 225, 224

e, $230,231,226,225$

e, 231, 232, 227, 226

e, 232, 210, 209, 227

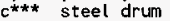

type, 5 \$mat, 2 \$real, 5

e, $147,246,151$

e, $246,245,250$

e. $245,244,249$

$c^{* * *}$ air gap/conduction link

type, 2 \$mat, 6 \$real, 12

e, 246,250

e, 245,249

e, 244,248

$c^{\star \star *}$ fiberglass insulation

type, 1 \$mat, 5

e, 248, 249, 253, 252

e, 249, 250, 254, 253

e, 250, 151, 155, 254

$c^{\star \star \star}$ polyurethane insulation

mat , 4

e, 252, 253, 257, 256

e. 253, 254, 258, 257

e, 254, 155, 159, 258

e, 256, 257, 261, 260

e, 257, 258, 262, 261

e, 258, 159, 163, 262

$c^{\star \star \star}$ galvanized steel

type,8 \$real, 15 \$mat, 8

e, 163, 262, 999

е, 262, 261, 999

e, 261, 260, 999

$c * * *$

$c^{* * *}$ section 3 el ements

$c^{\star * *}$ waste contents

type, 1 Smat 7

e, $100,201,311,311$

е, 201, 202, 312, 311

$c^{\star \star \star}$ canister

mat, 1

e, 202, 203, 313, 312

ck**

e, 203, 204, 328, 313

e, 313, 328, 314, 314

е, 328, 329, 315, 314

e, 329, 330, 316, 315

e, $330,331,317,316$

e, 331, 346, 347, 317

e, 332, 345, 346, 331

e, $210,244,345,332$

$c * \star *$ waste contents

mat, 7

e, 207, 318, 206, 206

e, 207, 319, 318, 318

e, 207, 320, 319, 319

e, 207, 321, 320, 320

e, 207, 322, 321, 321

e, 207, 208, 322, 322

e, 205, 206, 318, 323

e, 318, 319, 324, 323

e, 319, 320, 325, 324 
e, 320, 321, 326, 325

e, 321, 322, 327, 326

e, 322, 208, 209, 327

$c^{\star \star *}$ canister

mat, 1

e, 205, 323, 328, 204

e, 323, 324, 329, 328

e, 324, 325, 330, 329

e, 325, 326, 331, 330

e, 326, 327, 332, 331

е, 327, 209, 210, 332

$c^{\star \star \star *}$ steel drum

type, 5 \$mat, 2 \$real, 5

e, 244, 345, 248

e, $345,346,349$

e, 346, 347, 350

$c^{* \star *}$ air gap/conduction link

type, 2 \$mat,6 \$real, 12

e, 345,349

e, 346,350

e, 347,351

$c^{\pi * *}$ fiberglass insulation

type, 1 mat, 5

e, 248, 252, 353, 349

e, 349, 353, 354, 350

e, 350, 354, 355, 351

$c^{\star \star *}$ polyurethane insulation

mat, 4

e, $252,256,357,353$

e, 353, 357, 358, 354

e, 354, 358, 359, 355

e, 256, 260, 361, 357

е, 357, 361, 362, 358

e, $358,362,363,359$

$c^{* * *}$ galvanized steel

type, 8 \$real, 15 \$mat, 8

e, $260,361,999$

e, 361, 362, 999

e, 362, 363, 999

e, 362

$c^{\star \star \star}$ section 4 elements

$c^{* \star *}$

$c * *$ waste contents

type, 1 \$mat, 7

e, $100,311,401,401$

e, 311, 312, 402, 401

$c^{* * *}$ canister

mat, 1

e, 312, 313, 403, 402

$c^{* * *}$ polystyrene inner spacer

mat 3

$\mathrm{e}, 403,313,428,404$

e, $313,314,428,428$

e, 314, 315, 429, 428

e, $315,316,430,429$

e, 316, 317, 431, 430

e, 317, 347, 446, 431

е, 431, 446, 445, 432

e, 432, 445, 444, 410

$c^{\star \star *}$ waste contents

mat , 7

e, $407,406,418,418$

e, 407, 418, 419, 419

e, 407, 419, 420, 420

e, $407,420,421,421$

e, 407, 421, 422, 422

e, $407,422,408,408$

e, 405, 423, 418, 406

e, 423, 424, 419, 418

e, 424, 425, 420, 419

e, $425,426,421,420$

e, 426, 427, 422, 421

e $427,409,408,422$

$c^{k * *}$ canister

mat, 1

e, 404, 428, 423, 405 


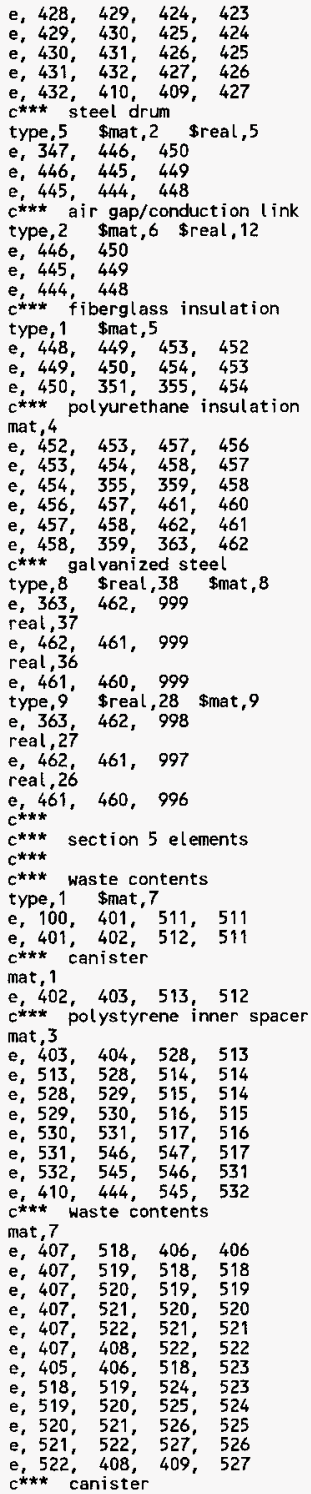


mat, 1

e. $405,523,528,404$

e, $523,524,529,528$

e, 524, 525, 530, 529

e, $525,526,531,530$

e, 526, 527, 532, 531

e, 527, 409, 410, 532

$c^{* * *}$ steel drum

type, 5 \$mat, 2 \$real, 5

e, 444, 545, 549

e, 545, 546, 550

e, 546, 547, 551

$c^{* * *}$ air gap/conduction link

type, 2 \$mat,6 \$real, 12

e, 545,549

e, 546, 550

e, 547, 551

*** fiberglass insulation

type, 1 \$mat, 5

e, 448, 452, 553, 549

e, 549, 553, 554, 550

e, 550, 554, 555, 551

$c^{* * *}$ polyurethane insulation

mat, 4

e, 452, 456, 557, 553

e, 553, 557, 558, 554

e, 554, 558, 559, 555

e, 456, 460, 561, 557

e, 557, 561, 562, 558

e, 558, 562, 563, 559

$c *$ galvanized steel

type, 5 \$real, 35 \$mat, 8

e, 460, 561, 999

real, 34

e, 561, 562, 999

reat, 33

e, 562, 563, 999

type, 9 \$real, 25 \$mat, 9

e, 460, 561, 995

real. 24

e. 561, 562, 994

real, 23

e. $562,563,993$

$c^{* \star *}$

$c^{* \star *}$ section 6 elements

$c^{\star \star \star}$

$c^{\star \star \star}$ waste contents

type, 1 Smat, 7

e, 601, 100, 511, 511

e, 602, 601, 511, 512

$c^{* * *}$ canister

mat, 1

e, 603, 602, 512, 513

$c^{\star * *}$ polystyrene inner spacer

mat, 3

e, 604, 603, 513,628

e, 628, 513, 514, 514

e, 628, 514, 515, 629

e, 629, 515, 516, 630

e, 630, 516, 517, 631

e, 631, 517, 547, 646

e, 632, 631, 646, 645

e, 644, 610, 632, 645

c*** waste contents

mat, $?$

e, 607,606,618,618

e, 607, 618, 619, 619

e, 607, 619, 620, 620

e, 607, 620,621, 621

e, 607, 621, 622, 622

e, 608, 607, 622, 622

e, 606, 605, 623, 618

e, 618, 623, 624, 619

e, 619, 624, 625, 620

e, 621, 620, 625, 626

e, 622, 621, 626, 627 
HNF-SD-TP-SARP-023 Rev. 0

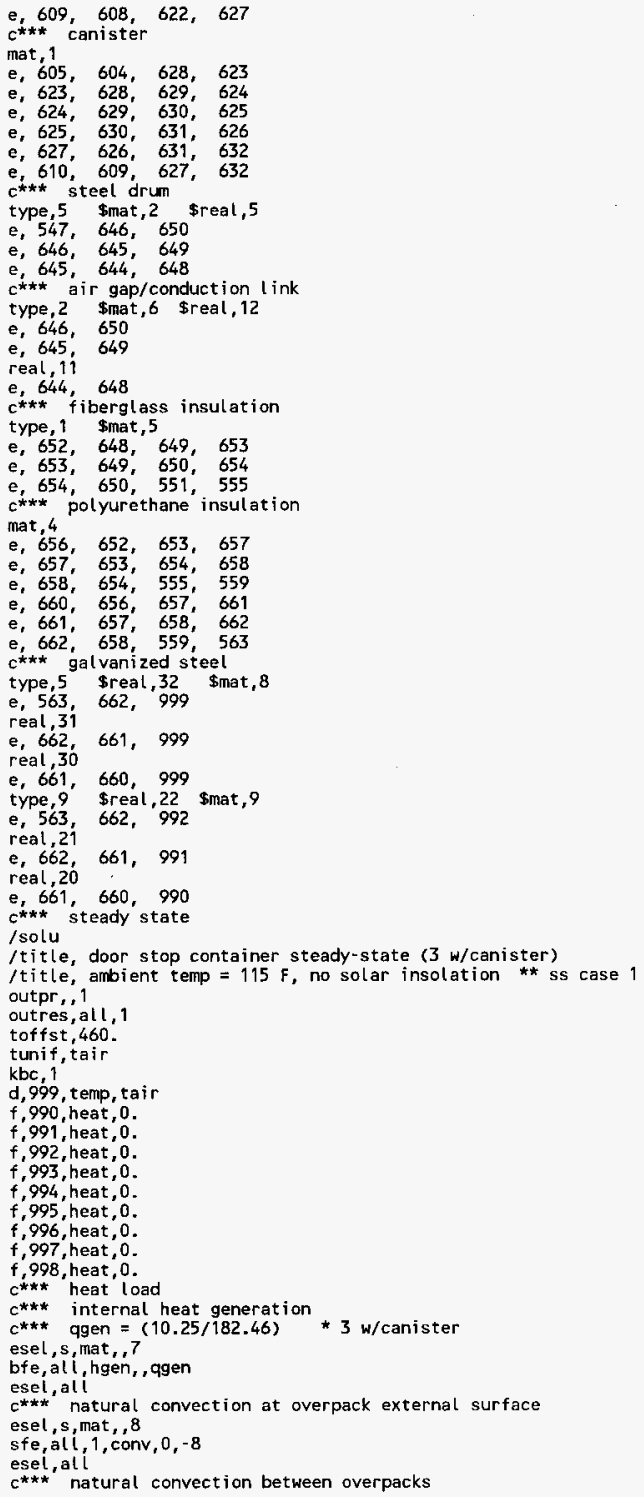


Rev. 0

esel, s, mat, , 9

sfe, all, 1, conv, $0,-9$

esel, alí

solve

finish 


\subsubsection{Thermal Evaluation Model for Accident Condition}

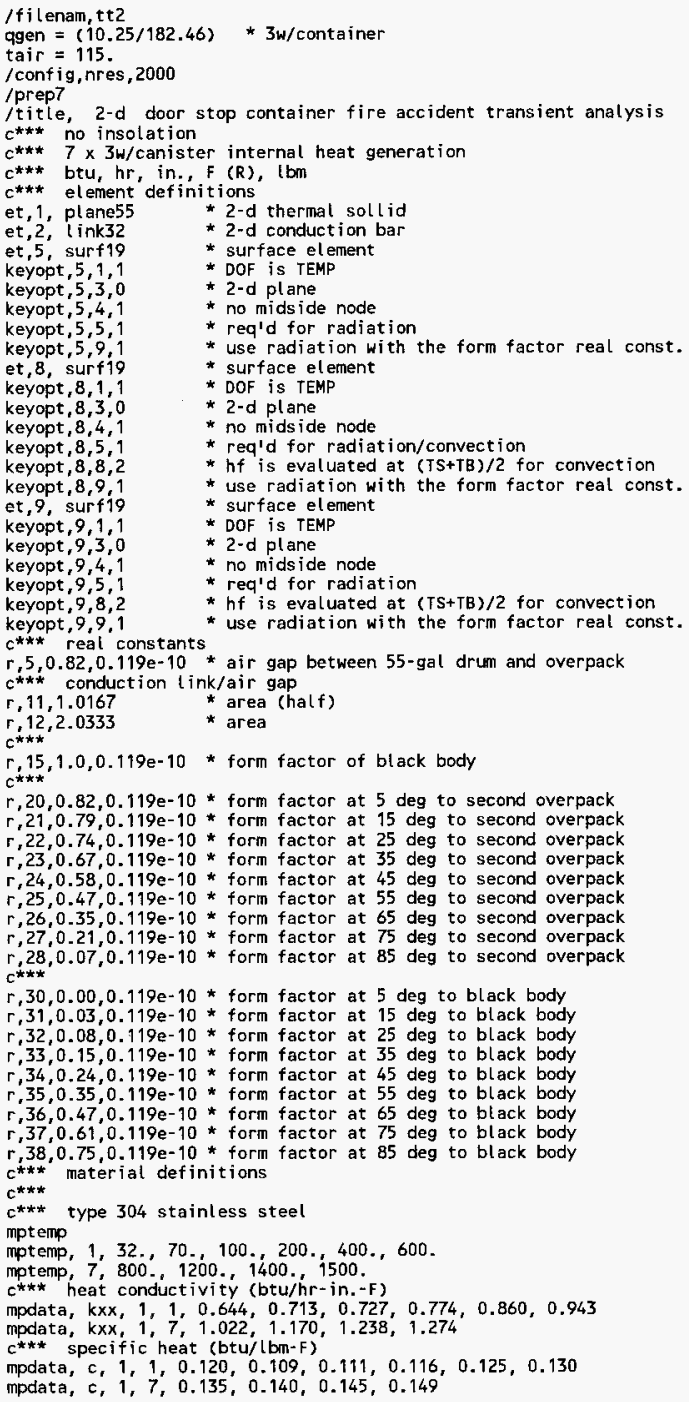




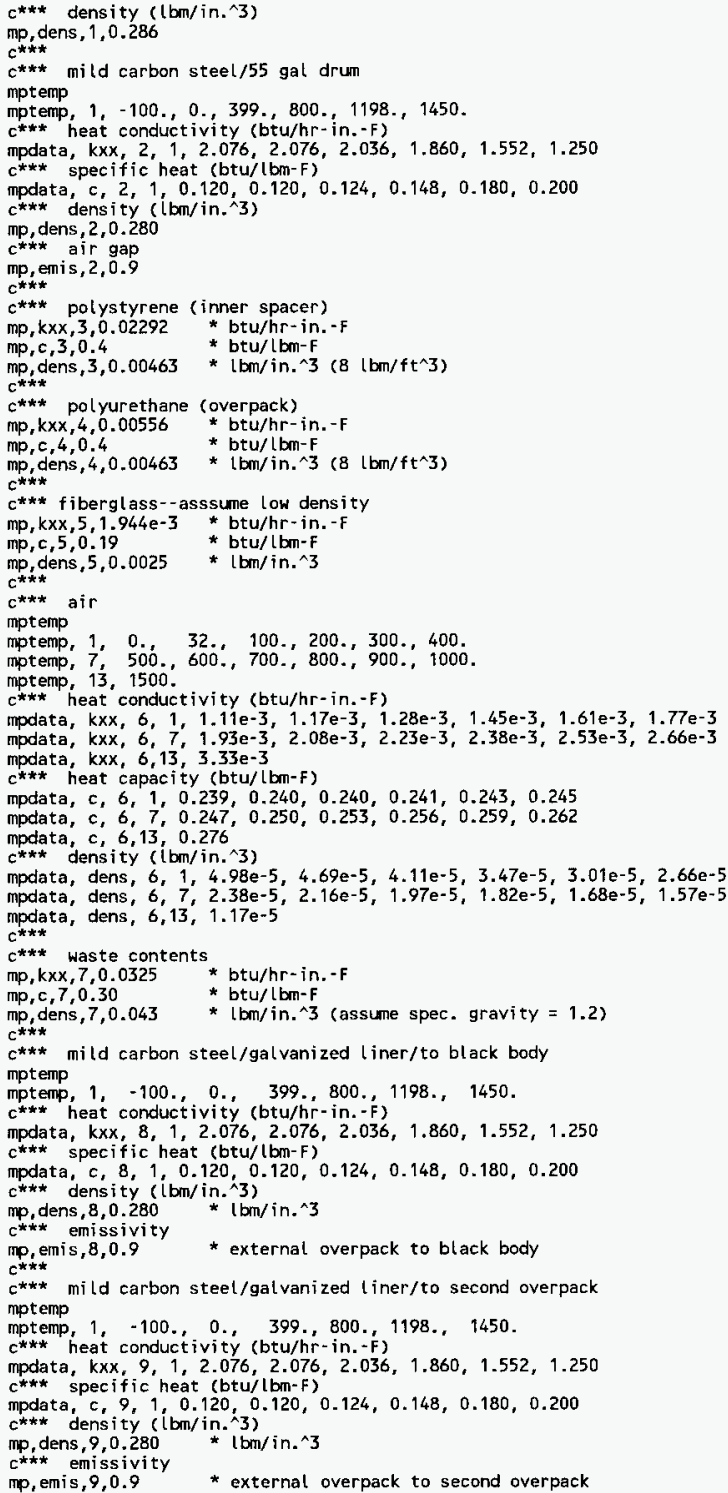




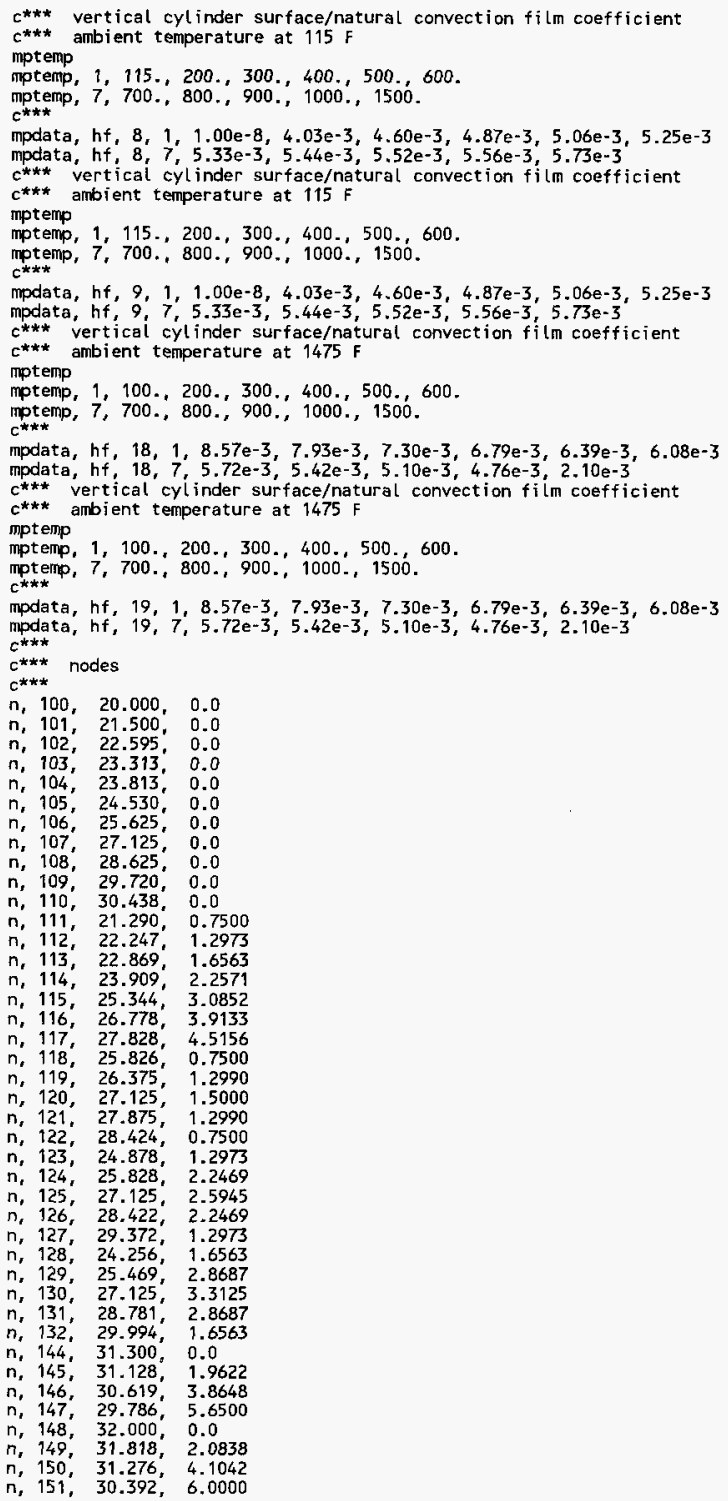


HNF-SD-TP-SARP-023 Rev. 0
n, 152, 32.500, 0.0
n, 153, 32.310, 2.1706
$n, 154,31.746,4.2753$
$n, 155,30.825,6.2500$
$n, 156,34.200,0.0$
$n, 157,33.984,2.4658$
$n, 158,33.344,4.8567$
$n, 159,32.298,7.1000$
n, 160, 35.875; 0.0
$n, 161,35.634,2.7567$
$n, 162,34.918,5.4296$
n, 163, 33.748, 7.9375
n, 201, 20.750, 1.2990
$\mathrm{n}, 202,21.297,2.2469$
n, 203, 21.656, 2.8687
ก, 204, 21.906, 3.3017
n, 205, 22.265, 3.9235
$n, 207,23.562,6.1704$
$\mathrm{n}, 208,24.312,7.4695$
$\mathrm{n}, 209,24.860,8.4173$
$n, 210,25.219,9.0391$
$\mathrm{n}, 218,23.563,4.6705$
n, 219, 24.312, 4.8714
$\mathrm{n}, 220,24.862,5.4204$
$n, 221,25.062,6.1705$
n, 222, 24.862, 6.9204
$n, 224$ ，24.860， 3.9236
$n, 225 ， 25.809$, 4.8732
$n, 226,26.157,6.1705$
n, 227， 25.809， 7.4677
n, 228, 23.563, 2.8579
$n, 229,25.219,3.3018$
$n, 230,26.431,4.5142$
n, 231, 26.875, 6.1705
$n, 232,26.431,7.8266$
$n, 244,25.650,9.7861$
$n, 245,27.263,8.6563$
$\mathrm{n}, 246,28.656,7.2635$
$\mathrm{n}, 248,26.000,10.392$
n', 249, 27.713, 9.1925
$n, 250,29.192,7.7135$
$n, 252$, 26.250, 10.825
ก, 253, 28.035, 9.5756
$n, 254,29.576,8.0349$
$\mathrm{n}, 255,30.825,6.2500$
$\mathrm{n}, 256,27.100,12.298$
$n, 257,29.128,10.878$
n, 258, 30.878, 9.1275
n, 259, 32.298, 7.1000
$n, 260,27.937,13.748$
n, 261, 30.204, 12.161
n, 262, 32.161, 10.204
n, 311, $19.995,1.4922$
n, 312, 20.000, 2.5945
n, 313, 20.000, 3.3125
n, 314, 20.000, 4.5142
n. 315, 20.000, 6.1705
$n, 316,20.000,7.8267$
$n, 317,20.003,9.0371$
$n, 318,22.263, \quad 5.4205$
$\mathrm{n}, 319$, 22.063， 6.1704
$n, 320 ， 22.263 ， 6.9204$
n, 321, 22.813, 7.4695
$n, 322,23.562, \quad 7.6704$
$n, 323,21.316,4.8732$
$n, 324$, 20.968, 6.1705
$n, 325,21.316,7.4677$
$n, 326,22.265,8.4174$
$n, 327,23.562,8.7650$
$n, 328,20.694,4.5142$
$n, 329,20.250,6.1705$
$n, 330,20.694,7.8267$
n. 331, 21.906, 9.0392
n. 332, 23.562, 9.4829 
HNF-SD-TP-SARP-023 Rev. 0

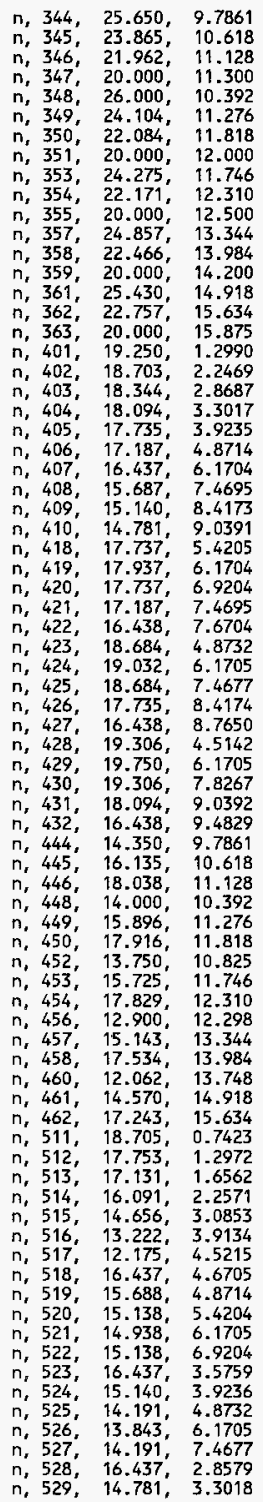


ก, 530, $13.569,4.5142$

n, 531, 13.125, 6.1705

$n, 532,13.569,7.8266$

n, $544,14.350,9.7861$

n, $545,12.737,8.6563$

n, 546, 11.344, 7.2635

n, 547, 10.214, 5.6500

n, 549, 12.287, 9.1925

ก. $550,10.808,7.7135$

ก, 551, 9.6077, 6.0000

n. 553, 11.965, 9.5756

$n, 554,10.424,8.0349$

n, 555, 9.1747, 6.2500

n, 557, 10.872, 10.878

$n, 558,9.1222,9.1275$

n, 559, 7.7024, 7.1000

$n, 561,9.7957,12.161$

$n, 562, \quad 7.8390, \quad 10.204$

$\mathrm{n}, 563,6.2518,7.9375$

$\mathrm{n}, 601,18.500,0.0$

$n, 602, \quad 17.405,0.0$

$n, 603,16.688,0.0$

$n, 604,16.188,0.0$

$n, 605,15.470$, 0.0

$n, 606 ; 14.375 ; 0.0$

$n, 607,12.875,0.0$

$n, 608,11.375,0.0$

$n, 609, \quad 10.280,0.0$

$n, 610,9.5625,0.0$

n, 618, 14.174, 0.7500

n, 619; 13.625, 1.2990

$n, 620,12.875, \quad 1.5000$

$\mathrm{n}, 621,12.125, \quad 1.2990$

n, 622, $11.576, \quad 0.7500$

$\mathrm{n}, 623,15.122,1.2973$

$n, 624,14.172,2.2469$

$n, 625,12.875$, 2.5945

$n, 626,11.578,2.2469$

$n, 627,10.628,1.2973$

n, 628, 15.744, 1.6563

$\mathrm{n}, 629,14.531,2.8687$

n, 630, 12.875, 3.3125

n, 631, 11.219, 2.8687

$n, 632,10.006,1.6563$

$n, 644,8.7000,0.0$

$n, 645,8.8717,1.9622$

$n, 646,9.3815,3.8648$

n, 648, 8.0000, 0.0

$n, 649,8.1823,2.0838$

$n, 650,8.7237,4.1042$

$n, 652,7.5000,0.0$

n, 653, 7.6899, 2.1706

$n, 654,8.2538,4.2753$

$n, 656,5.8000,0.0$

$n, 657,6.0157,2.4658$

$\mathrm{n}, 658,6.6564,4.8567$

$n, 660,4.1250,0.0$

$n, 661$; 4.3662, 2.7567

$\mathrm{n}, 662,5.0824,5.4296$

n, 999, 20., 20.

n, 990, $0.0, \quad 0$.

n, 991, 0.0, 2.7567

$\mathrm{n}, 992,0.0, \quad 5.4290$

$n, 993,0.0, \quad 7.9375$

$\mathrm{n}, 994,0.0, \quad 10.204$

$\mathrm{n}, 995,0.0, \quad 12.161$

$n, 996,0.0 ; \quad 13.748$

$\mathrm{n}, 997,0.0, \quad 14.918$

$n, 998,0.0, \quad 15.634$

ck**

c*** section 1 elements

$c * * *$

$c^{\star * *}$ waste contents

type, 1 \$mat, 7

e, $100,101,111,111$

e, 101; 102; 112; 111 


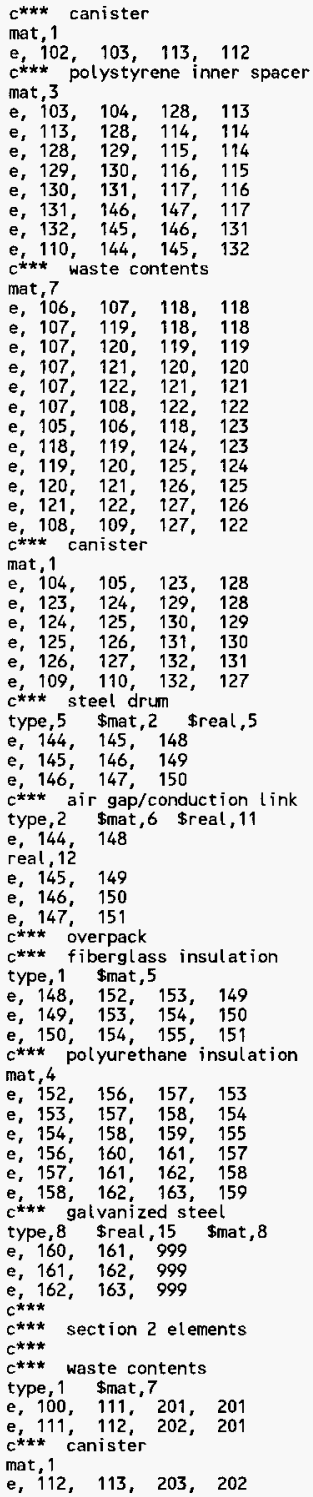


HNF-SD-TP-SARP-023 Rev. 0

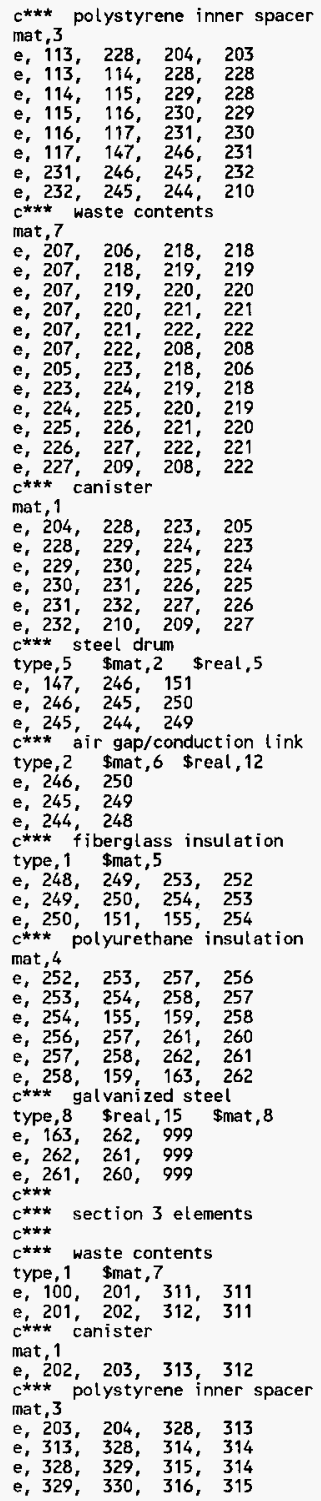


HNF-SD-TP-SARP-023 ReV. 0

e, $330,331,317,316$

e, 331, 346, 347, 317

e, 332, 345, 346, 331

e, 210, 244, 345, 332

$\mathrm{c}^{* * * *}$ wat, 7 waste contents

e, 207, 318, 206, 206

e, 207, 319; 318, 318

e, 207, 320, 319, 319

e, 207, 321, 320, 320

e, 207, 322, 321, 321

e, 207, 208, 322, 322

e, 205, 206, 318, 323

e, 318, 319, 324, 323

e, 319, 320, 325, 324

e, 320, 321, 326, 325

е, 321, 322, 327, 326

e, 322, 208, 209, 327

c**** canister

mat, 1

e, $205,323,328,204$

е, 323, 324, 329, 328

e, 324, 325, 330, 329

e, $325,326,331,330$

e, 326, 327, 332, 331

e, 327, 209, 210, 332

c*** steel drum

type, 5 \$mat, 2 \$real,5

e, $244,345,248$

e. $345,346,349$

e, $346,347,350$

$c^{* * *}$ air gap/conduction link

type, 2 \$mat, 6 \$real, 12

e, 345,349

e, 346, 350

e, 347, 351

$c^{\star * \star}$ fiberglass insulation

type, 1 \$mat, 5

e, 248, 252, 353, 349

e, 349, 353, 354, 350

e, 350, 354, 355, 351

$c^{\star * *}$ polyurethane insulation

mat, 4

e, 252, 256, 357, 353

e, 353, 357, 358, 354

e, $354,358,359,355$

e, 256, 260, 361, 357

e, 357, 361, 362, 358

e, 358, 362, 363, 359

c*** galvanized steel

type, 8 \$real, 15 \$mat, 8

e, 260, 361, 999

e, 361, 362, 999

e, 362, 363, 999

$c * * *$

$c^{* * *}$ section 4 elements

$c \hbar \hbar \star$

$c^{\star \star \star}$ waste contents

type, 1 \$mat, 7

e, 100, 311, 401, 401

e, 311, 312, 402, 401

$c^{\star * *}$ canister

mat, 1

e, 312, 313, 403, 402

$c * * *$ polystyrene inner spacer

mat, 3

e, 403, 313, 428, 404

e, 313, 314, 428, 428

e, 314, 315, 429, 428

e, 315, 316, 430, 429

e, 316, 317, 431, 430

e, 317, 347, 446, 431

e, 431, 446, 445, 432

e, 432, 445, 444, 410

$c^{\star * *}$ waste contents

mat, 7 


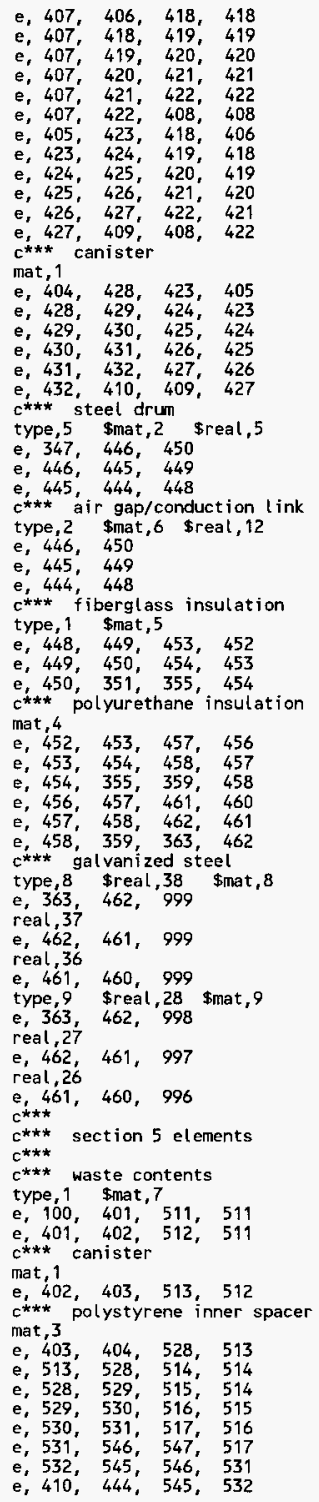




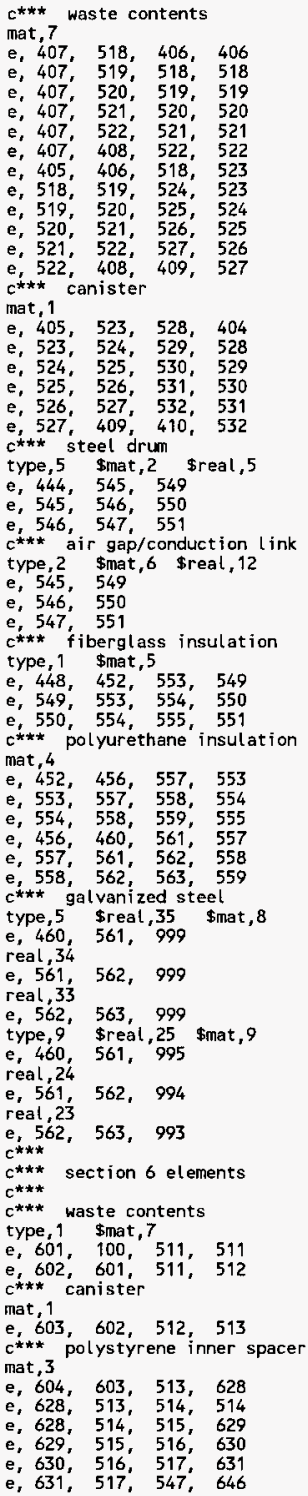




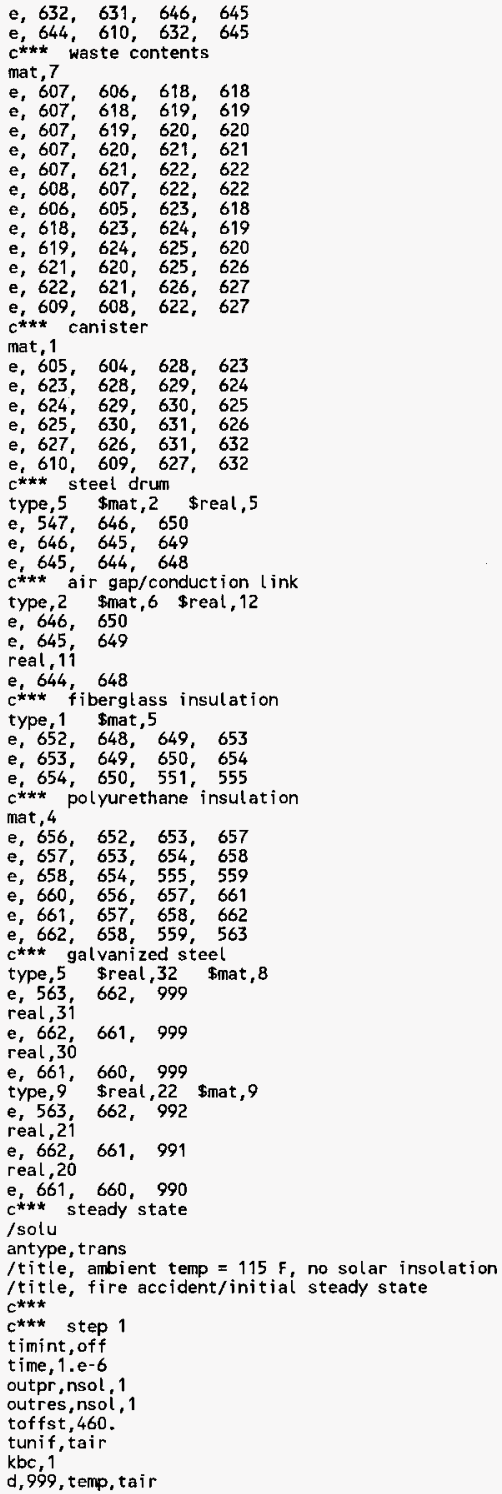




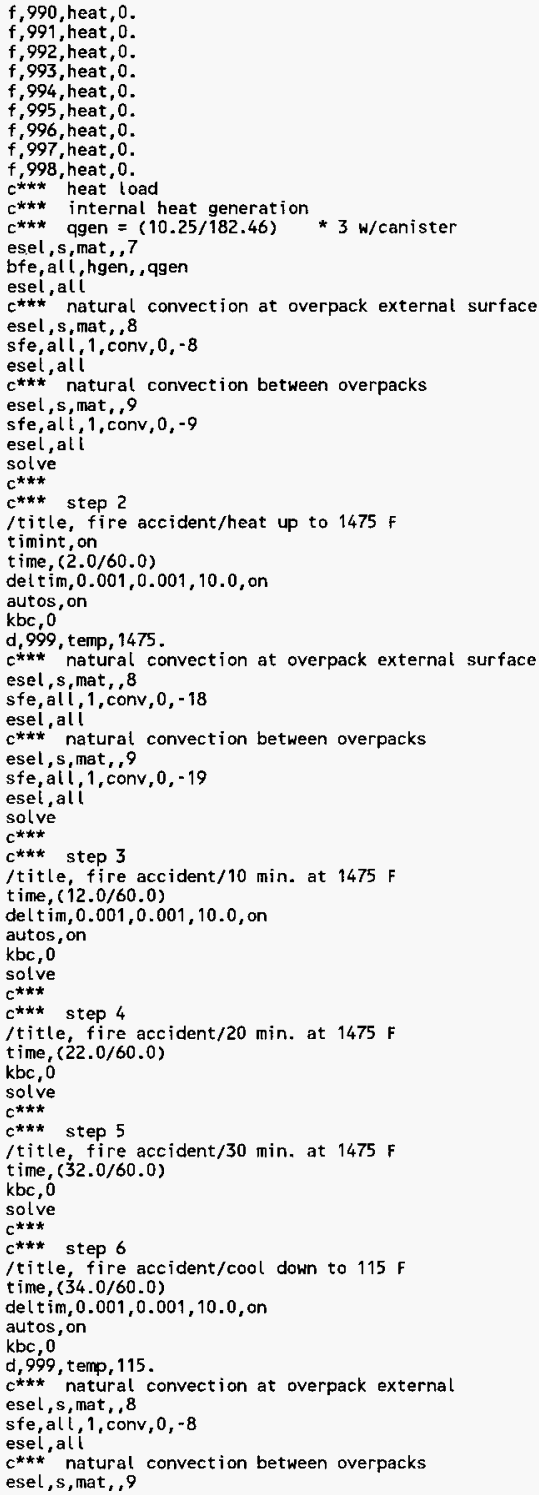


HNF-SD-TP-SARP-023 Rev. 0

sfe, all, 1, conv, $0,-9$

solve

$c * \hbar *$

c*** step 7

/title, fire accident/30 min. at $115 \mathrm{~F}$ after the accident

time, (64.0/60.0)

del tim, 0.001,0.001,10.0, on

autos, on

$k b c, 0$

solve

$c * \star \star$

$c^{\star \star \star}$ step 8

title, fire accident $/ 200 \mathrm{hr}$ at $115 \mathrm{~F}$ after the accident

time, (12004.0/60.0)

$\mathrm{kbc}, 0$

solve

finish 
HNF-SD-TP-SARP-023 ReV. 0

\section{Checklist for Checking of Analysis/Calculations}

Document Checked - Number:

N/A

Revision:

0

Title:

Doorstop Container Thermal Evaluation

Yes № No

[x] [ ] [ ] Problem completely defined.

[x] [ ] [ ] Appropriate analytical method used.

[x] [ ] [ ] Necessary assumptions are approriate, explicitly stated, and stated.

[ $x$ ] [ ] [ ] Computer codes and data files documented.

[ $\mathrm{x}]$ [ ] [ ] Data used in calculations explicitly stated in document.

[ ] [ ] [x] Sources of non-standard formulag/data are referenced and the correctness of the reference verified.

[ $x$ [ [ ] [ ] Data checked for consistency with original source information as applicable.

[ ] [ ] [x] Mathematical derivations checked including dimensional consistency of results.

[x] [ ] [ I Models appropriate and used within range of validity or use cutside range of established validity justified.

[ ] [ ] [x] Hand calculations checked for errors.

[ $x$ ] [ ] [ ] Code run streans correct and consistent with analysis documentation.

[x] [ ] [ ] Code output consistent with input and with results reported in analysis documentation.

[x] [ ] [ ] Acceptability limits on analytical results applicable and supported. Limits checked against sources.

[ $\mathrm{x}$ [ [ ] [ ] Safety Margins consistent with good engineering practices.

[x] [ ] [ ] Conclusions consistent with analytical resu!ts and applicable limits.

[ $x$ [ [ ] [ ] Results and conclusions address all points required in the problem staternert.

I have checked the analysis/galculation and it is complete and accurate to the best of my knowledge.

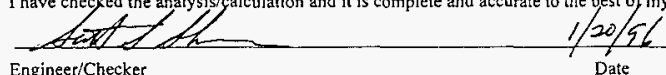

Note: Any hand calculations, notes or summaries generated as part of this check should be signed, dated, and attached to this checklist. Material should be labeled and recorded so that it is intelligible to a technically qualified third party. 


\subsection{PRESSURE AND GAS GENERATION EVALUATION}

The maximum content of the Doorstop Sample Carrier System is seven, $125 \mathrm{~mL}(4.3 \mathrm{fl} \mathrm{oz})$ samples, one sample per Doorstop container. When fully loaded, the package contains $875 \mathrm{~mL}(29.6 \mathrm{fl} \mathrm{oz})$ of tank waste. The tank waste is known to generate hydrogen and other gases. The total gas generation within a Doorstop container was calculated. In addition to pressure generation, the production of hydrogen results in a potential flammability hazard. The flammability is the limiting gas generation hazard. As a result of the flammability hazard, an administrative control is placed on the length of time the Doorstop container may be sealed. A shipping window of half the estimated time to reach the lower flammability limit (LFL) of the gas mixture is used to ensure safe transport of the samples.

\subsection{GAS GENERATION}

The evaluation can be found in Part B, Section 9.3.1, describing the process used to determine the generation rate and allowable seal time (shipping window) for the Doorstop container. A gas mixture generation rate was determined in this evaluation. Table B9-1 details allowable seal time (shipping window), pressure rise during seal time, and total gas generation rate.

Table B9-1. Gas Generation in $875 \mathrm{~mL}$ (29.6 oz) Samples in the Doorstop Sample Carrier System.

\begin{tabular}{|l|c|c|c|}
\cline { 2 - 4 } \multicolumn{1}{c|}{} & \multicolumn{3}{c|}{ Worst Case Material } \\
\cline { 2 - 4 } \multicolumn{1}{c|}{ Payload volume } & $1.6 \mathrm{~mL}$ & $20 \mathrm{~mL}$ & $125 \mathrm{~mL}$ \\
\hline Shipping window & 39 days & 6.4 days & 4.8 days \\
\hline $\begin{array}{l}\text { Pressure rise to } 50 \% \text { lower flammability } \\
\text { limit (psi) }\end{array}$ & 0.455 & 0.456 & 0.456 \\
\hline Pressure rise in 45 days (psi) & 0.52 & 3.19 & 4.24 \\
\hline
\end{tabular}

\subsection{PACKAGE PRESSURE}

The package's ability to withstand pressure is discussed in Part B, Section 7.6.3. The Doorstop container is shown to be capable of withstanding an internal pressure of 14.44 psi greater than the external pressure. That pressure accounts for the maximum pressure of 4.24 psi calculated to be produced in 45 days. 
HNF-SD-TP-SARP-023 ReV. 0

\subsection{APPENDICES}

\subsubsection{Hydrogen Gas Generation Calculations}

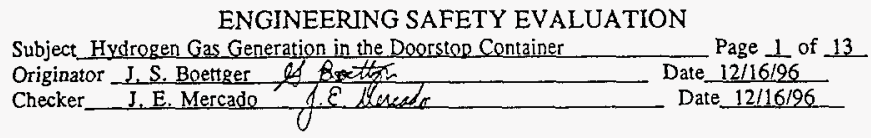

\section{Objectives:}

Samples will be shipped from the Tank Waste Remediation System (TWRS) double shell tanks and single shell tanks in the Doorstop Sample Carrier (Doorstop). The tank waste is known to generate hydrogen as well as other gases and an evaluation of gas generation is necessary to ensure transportation safety. The purpose of this analysis is to quantify the amount of hydrogen and other gases generated within the container, and to determine the pressure buildup from the generated gases. A shipping window of half of the estimated time to reach the lower flammability limit (LFL) of the gas mixture will be used to ensure safe transport of the samples. Decay heat is also calculated.

\section{References:}

Graves, R. D., 1994, Topical Report on Flammable Gases in Nonburping Waste Tanks, WHC-SD-WM-SARR-015, Westinghouse Hanford Company, Richland, Washington.

Green, J. R., K. Hillesland, V. E. Roetman, and J. G. Field, 1995, Radcalc for Windows, Version 1.0, Westinghouse Hanford Company, Richland, Washington.

Hopkins, J. D:, 1994, Criteria for Flamnable Gas Watch List Tanks, WHC-EP-0702, Westinghouse Hanford Company, Richland, Washington.

Kummerer, M., 1995, Pressure and Gas Generation Evaluation for LLCE Containers, Draft Report, Westinghouse Hanford Company, Richland, Washington.

Meisel, D., C. D. Jonah, S. Kapoor, M. S. Matheson, and M. C. Sauer, Jr., 1993, Radiolytic and Radiolytically Induced Generation of Gases from Synthetic Wastes, ANL-93/43, Argonne National Laboratory, Argonne, Illinois.

NRC, 1984, Clarification of Conditions for Waste Shipments Subject io Hydrogen Gas Generation, IN 84-72, Nuclear Regulatory Commission, Washington, D.C.

WHC, 1995, Safery Analysis Report for Packaging for the LR-56, WHC-SD-TP-SARP-009, Westinghouse Hanford Company, Richland, Washington.

\section{Results and Conclusions:}

The following table summarizes the results calculated using the methods described in Section IV of this report. Three worst case scenarios for the Doorstop are considered. 
HNF-SD-TP-SARP-023 Rev. 0

ENGINEERING SAFETY EVALUATION

Subject Hydrogen Gas Generation in the Doorstop Container

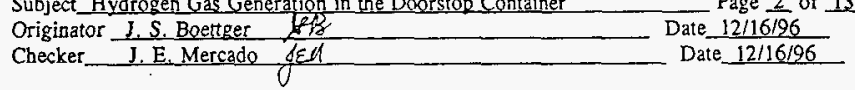

Table 1. Summary of Results for the Doorstop Sample Carrier.

\begin{tabular}{|l|c|c|c|}
\cline { 2 - 4 } \multicolumn{1}{c|}{} & \multicolumn{3}{|c|}{ Worst Cases } \\
\hline Payload volume & $1.6 \mathrm{ml}$ & $20 \mathrm{ml}$ & $125 \mathrm{mI}$ \\
\hline Half of the time to reach LFL & 39 days & 6.4 days & 4.8 days \\
\hline Pressure rise to $50 \%$ LFL (psi) & 0.455 & 0.456 & 0.456 \\
\hline Pressure rise in 45 days (psi) & 0.52 & 3.19 & 4.24 \\
\hline Decay heat $(W)$ & 0.000852 & 0.0113 & 0.0694 \\
\hline
\end{tabular}

For all cases in this report, the LFL of the mixture is reached when hydrogen gas equals $2.5 \%$ by volume. The NRC allows a shipping envelope of half the time it takes to reach $5 \%$ hydrogen gas by volume or the LFL of gas mixtures (NRC 1984). Because the LFL of the gas mixture is reached when the hydrogen gas reaches $2.5 \%$ by volume (WHC 1995), the shipping window is determined to be half of the time it takes to reach $2.5 \%$ hydrogen gas.

\section{Engineering Evaluation:}

Tank waste generates hydrogen, oxygen, nitrous oxide, ammonia, and methane by radiolytic and chemical interactions. Many reports have been generated regarding flammable gas generation in the TWRS tanks and a method for estimating the expected gas generation from tank waste materials was developed in Topical Report on Flammable Gases in Nonburping Waste Tarks (Graves 1994). The method focuses on both radiolytical and chemical generation of gases. The method uses empirical data from experiments and sample data from waste.

\section{Radiolytic Generation}

The method used in Topical Report on Flammable Goses in Nonburping Waste Tanks (Graves 1994) for the radiolytic generation of hydrogen is known as the $G$ value method and is a well accepted calculational technique. The $\mathrm{G}$ value method has also been developed in the computer code Radcalc for Windows (Green et al. 1995). The computer code was accordingly used to determine the hydrogen generation from radiolytic interactions. It is also used to calculate decay heat. The input parameters used in the code for the two containers are given in Table 2 and the source term used in the code input files is given in Table 3 . The source term used was taken from the worst case source terms developed for the Doorstop SARP. The source term development is discussed in Part B, Section 2.0 of the SARP.

A container model for the Doorstop is contained within RadCalc for Windows and is used in the determination of gamma absorption fractions. For more information on this model see Volume II, Technical Manual, of the RadCalc for Windows computer code (Green et al. 1995). 
ENGINEERING SAFETY EVALUATION

Subject Hydrogen Gas Generation in the Doorstop Container Originator J.S. Boettger /4.

Checker J. E. Mercado 1 UU

Page 3 of 13 Date_12/16/96 Date 12/16/96

Table 2. Container Input Values.

\begin{tabular}{|l|c|c|c|}
\cline { 2 - 4 } \multicolumn{1}{c|}{} & \multicolumn{3}{c|}{ Doorstop } \\
\hline Waste volume & $1.6 \mathrm{ml}$ & $20 \mathrm{ml}$ & $125 \mathrm{ml}$ \\
\hline Waste mass & $2.56 \mathrm{~g}$ & $32.0 \mathrm{~g}$ & $200 \mathrm{~g}$ \\
\hline Waste density & $1.6 \mathrm{~g} / \mathrm{cm}^{3}$ & $1.6 \mathrm{~g} / \mathrm{cm}^{3}$ & $1.6 \mathrm{~g} / \mathrm{cm}^{3}$ \\
\hline Void volume & $82.1 \mathrm{ml}$ & $177 \mathrm{ml}$ & $821 \mathrm{ml}$ \\
\hline
\end{tabular}

Essential to the $G$ value method of calculating the radiolytic production of hydrogen gas is the value chosen for $\mathrm{G}\left(\mathrm{H}_{2}\right) . \mathrm{G}\left(\mathrm{H}_{2}\right)$ is equal to the number of molecules generated per $100 \mathrm{eV}$ of ionizing radiation. The $\mathrm{G}\left(\mathrm{H}_{2}\right)$ value used by Kummerer in the LR-56 SARP (WHC 1995) and in an analysis of the Long Length Contaminated Equipment (Kummerer 1995) is 0.119. She arrives at this value by adding the $G$ value for dissolved organic compound solutions containing nitrates/nitrites to a variable dependent upon the concentration of organics (TOC) within the tanks. This calculation is described in detail in the LR-56 SARP. The $\mathrm{G}\left(\mathrm{H}_{2}\right)$ value developed in the SARP is adopted for use in this analysis for gamma and beta interactions. For alpha interactions the value was conservatively increased by a factor of four (Green et al. 1995).

The Radcalc input/output files for all the Doorstop cases run are listed in the Appendix of this evaluation. Radcalc assumes a waste temperature of $20^{\circ} \mathrm{C}$ when calculating hydrogen generation. The Ideal Gas Law is used to convert this value to the generation rate at $82^{\circ} \mathrm{C}$. The results of the radiolytic generation of hydrogen gas and heat generated from radioactive decay are given in Table 4. 


\section{ENGINEERING SAFETY EVALUATION}

Subject Hydrogen Gas Generation in the Doorstop Container Originator J.S. Boettger QS Checker J. E Mercado

Table 3. Worst Case Source Terms for the Doorstop.

\begin{tabular}{|c|c|c|c|c|}
\hline Nuclide & $\begin{array}{l}\text { Activity } \\
\text { Concentration } \\
\text { (CiL) }\end{array}$ & $\begin{array}{c}1.6 \mathrm{ml} \\
\text { Waste Volume }\end{array}$ & $\begin{array}{c}20 \mathrm{ml} \\
\text { Waste Volume }\end{array}$ & $\begin{array}{l}125 \mathrm{ml} \\
\text { Waste Volume }\end{array}$ \\
\hline${ }^{14} \mathrm{C}$ & 4.3 E.06 & $6.9 \mathrm{E}-09$ & 8.6 E.08 & $5.4 \mathrm{E}-07$ \\
\hline${ }^{\infty} \mathrm{Co}$ & $1.3 \mathrm{E}-02$ & $2.1 \mathrm{E}-0 \mathrm{~S}$ & $2.6 \mathrm{E}-04$ & 1.6 E.03 \\
\hline$\pi s$ & $4.6 \mathrm{E}-07$ & 7.4 E-10 & 9.2 E-09 & $5.8 \mathrm{E}-08$ \\
\hline${ }^{90} \mathrm{St}$ & $7.8 \mathrm{E} \div 01$ & $1.2 \mathrm{E}-01$ & $1.6 \mathrm{E}+\infty$ & $9.8 E+\infty$ \\
\hline $\mathrm{Y}$ & $7.8 \mathrm{E}+01$ & $1.2 \mathrm{E}-01$ & $1.6 \mathrm{E}+\infty$ & $9.8 \mathrm{E}+\infty$ \\
\hline${ }^{9} \mathrm{Tc}$ & $3.2 \mathrm{E}-01$ & $5.1 \mathrm{E}-04$ & $6.4 \mathrm{E}-03$ & $40 \mathrm{E}-02$ \\
\hline${ }^{106} \mathrm{Ru}$ & 1.9 E-06 & $3.0 \mathrm{E}-09$ & $3.8 \mathrm{E}-08$ & 2.4 E- 07 \\
\hline${ }^{106} \mathrm{Rh}$ & $1.9 \mathrm{E}-06$ & $3.0 \mathrm{E}-09$ & $3.8 \mathrm{E}-0.8$ & $2.4 \mathbf{E}-07$ \\
\hline${ }^{\mathrm{Br}} \mathrm{Sb}$ & $4.9 E-03$ & $7.8 \mathrm{E}-06$ & 9.8 E-OS & $6.1 \mathrm{E}-04$ \\
\hline 131 & $1.7 \mathrm{E}-04$ & $2.7 \mathrm{E}-07$ & $3.4 \mathrm{E}-06$ & $2.1 \mathrm{E} .05$ \\
\hline${ }^{134} \mathrm{C}$ & 2.5 E-04 & $4.0 \mathrm{E}-07$ & $5.0 \mathrm{E}-06$ & 3.1 E-OS \\
\hline${ }^{17} \mathrm{Cs}$ & $2.7 \mathrm{E}+00$ &, $4.3 E 03$ & $5.4 \mathrm{E}-02$ & $3.4 E-01$ \\
\hline 57"ma & $2.6 E+\infty$ & 4.2 E-03 & $5.2 \mathrm{E}-02$ & $3.3 \mathrm{E}-01$ \\
\hline${ }^{14} \mathrm{Ce}$ & $9.2 \mathrm{E}-09$ & $1.5 \mathrm{E} \cdot 11$ & $1.8 \mathrm{E}-10$ & $1.2 \mathrm{E}+09$ \\
\hline${ }^{m} \mathrm{Pr}$ & $9.2 \mathrm{E}-09$ & $1.5 \mathrm{E}-11$ & $1.8 \mathrm{E}-10$ & $1.2 \mathrm{E}-09$ \\
\hline${ }^{154} \mathrm{Eu}$ & $3.0 \mathrm{E}-01$ & $4.8 \mathrm{E}-04$ & $6.0 \mathrm{E}-03$ & $3.8 \mathrm{E}-02$ \\
\hline${ }^{135} \mathrm{Eu}$ & $1.4 E-04$ & 2.2 E -07 & $2.8 \mathrm{E}-06$ & $1.8 \mathrm{E}-05$ \\
\hline${ }^{27} \mathrm{~Np}$ & 2.7 E-O2 & $4.3 \mathrm{E}-\mathrm{OS}$ & 5.4 E-OA & $3.4 \mathrm{E}-03$ \\
\hline${ }^{234} \mathrm{Pu}$ & $5.1 \mathrm{E}-03$ & $8.2 \mathrm{E}-06$ & $1.0 \mathrm{E}-04$ & $6.4 \mathrm{E}-04$ \\
\hline${ }^{20} \mathrm{Pu}$ & $4.3 E-02$ & 6.9 E-0S & $8.6 \mathrm{E}-04$ & 5.4 E-03 \\
\hline${ }^{240 \mathrm{Pu}}$ & $4.3 \mathrm{E}-\mathrm{d}^{2}$ & 6.9 E-05 & $8.6 \mathrm{E}-04$ & $5.4 \mathrm{E}-03$ \\
\hline${ }^{24 !} \mathrm{Pu}$ & $1.0 \mathrm{E}-01$ & 1.6 E-04 & $2.0 \mathrm{E}-03$ & $1.3 \mathrm{E}-02$ \\
\hline${ }^{241} \mathrm{Am}$ & $3.0 E-01$ & $4.8 \mathrm{E}-04$ & $6.0 \mathrm{E}-0.3$ & $3.8 \mathrm{E}-02$ \\
\hline${ }^{242} \mathrm{Cm}$ & 5.4 E-09 & $8.6 \mathrm{E}-12$ & $1.1 \mathrm{E}-10$ & $6.8 \mathrm{E}-10$ \\
\hline${ }^{2+4} \mathrm{Cm}$ & $1.6 \mathrm{E}-03$ & $2.6 \mathrm{E}-06$ & $3.2 \mathrm{E}-05$ & $2.0 \mathrm{E}-04$ \\
\hline TOTALS & $1.6 \mathrm{E}+02$ & $2.5 \mathrm{E}-0 \mathrm{~L}$ & $3.2 \mathrm{E}+\infty$ & $2.1 \mathrm{E}+01$ \\
\hline
\end{tabular}


Table 4. Radiolytic Generation Rates and Decay Heat for the Doorstop.

\begin{tabular}{|l|c|c|c|}
\cline { 2 - 4 } \multicolumn{1}{c|}{} & \multicolumn{3}{c|}{ Waste Volume } \\
\cline { 2 - 4 } \multicolumn{1}{c|}{} & $1.6 \mathrm{ml}$ & $20 \mathrm{ml}$ & $125 \mathrm{ml}$ \\
\hline $\mathrm{H}_{2}$ production rate $\left(\mathrm{cm}^{3} / \mathrm{h}\right)$ & 0.000964 & 0.0128 & 0.0787 \\
\hline Decay heat $(W)$ & 0.000852 & 0.0113 & 0.0694 \\
\hline
\end{tabular}

Chemical Generation Rate

The chemical generation rate of hydrogen is dependent on the organic species, temperature, total organic carbon ( $T O C$ ), and activation energy. Tank waste and void volume temperature are assumed to be $82^{\circ} \mathrm{C}$ (Kummerer 1995). Experiments with tank waste simulant has lead to the following equation which can be used to estimate the chemical generation rate:

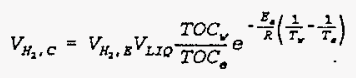

Where:

$$
\begin{aligned}
& V_{\text {H2.C }}=\text { Hydrogen chemical generation rate (L/day) } \\
& \mathrm{V}_{\mathrm{H} 2 \mathrm{E}}=\text { Hydrogen generation rate in experimental solution at } 60^{\circ} \mathrm{C} \text {, volume } \\
& \mathrm{V}_{\text {biq }}=\quad \text { adjusted to vapor space temperacire } \\
& \mathrm{E}_{\mathrm{a}}=\text { Activation energy }\left(4.09 \times 10^{\circ} \mathrm{J} / \mathrm{mol}\right. \text { ) (Meisel 1993) } \\
& \mathrm{R}=\text { Universal gas constant }(8.314 \mathrm{~J} / \mathrm{mol} \mathrm{K}) \\
& \mathrm{T}_{\mathrm{w}}=\text { Waste temperature }(355 \mathrm{~K}) \\
& \mathrm{T}_{*}=\text { Temperature of experimental solution }(333 \mathrm{~K}) \\
& \text { TOC }_{w}=\text { TOC in the waste, based on SST measurements }(52 \mathrm{~g} / \mathrm{L}) \\
& \text { TOC. }=\text { TOC in the experimental solution }(23 \mathrm{~g} / \mathrm{L})
\end{aligned}
$$

The generation rate of hydrogen at $355 \mathrm{~K}$ is $1.864 \times 10^{-3} \mathrm{~L} / \mathrm{day} / \mathrm{L}$ solution. The generation rates for the Doorstop are given in Table 5 , converted to $\mathrm{cm}^{3} / \mathrm{hr}$.

Table 5. Chemical Generation Rates.

\begin{tabular}{|l|c|c|c|}
\cline { 2 - 4 } \multicolumn{1}{c|}{} & \multicolumn{3}{|c|}{ Waste Volume } \\
\cline { 2 - 4 } \multicolumn{1}{c|}{$\mathrm{H}_{2}$ production rate $\left(\mathrm{cm}^{3} / \mathrm{h}\right)$} & $1.6 \mathrm{ml}$ & $20 \mathrm{ml}$ & $125 \mathrm{ml}$ \\
\hline \hline
\end{tabular}




\section{Lower Flammability Limit Calculation}

Hydrogen gas in combination with other gases generated from tank waste reaches the mixture lower flammability limit (LFL) when hydrogen totals $2.5 \%$ by volume (WHC 1995).

Accordingly, the time to reach the LFL of the mixture can be derived by the following:

$$
t=0.025\left(\frac{V_{v}}{I_{g e x}}\right)
$$

Where:

$$
\begin{array}{ll}
\mathrm{t} & =\text { time to } 2.5 \% \text { hydrogen } \\
\mathrm{v}_{\mathrm{v}} & =\text { void volume }\left(\mathrm{cm}^{3}\right) \\
\mathrm{r}_{\mathrm{m}} & =\text { generation rate }\left(\mathrm{cm}^{3} / \text { unit time }\right)
\end{array}
$$

Total generation rate and void volumes for the Doorstop are substituted in the above equation. The results are summarized in Table 6.

Table 6. Total Hydrogen Gas Generation Rates for the Doorstop.

\begin{tabular}{|l|c|c|c|}
\cline { 2 - 4 } \multicolumn{1}{c|}{} & \multicolumn{3}{|c|}{ Waste Volume } \\
\cline { 2 - 4 } \multicolumn{1}{c|}{} & $1.6 \mathrm{ml}$ & $20 \mathrm{ml}$ & $125 \mathrm{ml}$ \\
\hline Chemical generation $\left(\mathrm{cm}^{3} / \mathrm{h}\right)$ & 0.000124 & 0.00155 & 0.00971 \\
\hline Radiolytic generation $\left(\mathrm{cm}^{3} / \mathrm{h}\right)$ & 0.000964 & 0.0128 & 0.0787 \\
\hline Total $\mathrm{H}_{2}$ generation $\left(\mathrm{cm}^{3} / \mathrm{h}\right)$ & 0.00109 & 0.0144 & 0.0884 \\
\hline Time to reach LFL of mixture & 78 days & 13 days & 9.7 days \\
\hline Half the time to reach LFL & 39 days & 6.4 days & 4.8 days \\
\hline
\end{tabular}

\section{Total Pressure Rise}

In addition to hydrogen gas generation, chemical and radiolytical processes generate other gases that will affect the pressure rise within the container. Radiolytic generation produces other gases in a ratio to hydrogen gas of $1.5: 1$. Chemical generation produces $43.5 \%$ hydrogen gas, the remaining $56.5 \%$ consists of other gases (Kummerer 1995). These ratios can be used to calculate the total gas generation rates for each case (See Table 7 below). The rate of pressure rise can then be determined using the following equation (WHC 1995): 


\section{ENGINEERING SAFETY EVALUATION}

Subject Hydrogen Gas Generation in the Doorstop Container Originator J.S. Boettger $18 \mathrm{~B}$

$$
p=\frac{\left(r_{g o n}\right)\left(C_{a}\right)(R)\left(T_{k}\right)}{\left(V_{v}\right)}\left(C_{\text {pras }}\right)
$$

Where:

$$
\begin{array}{ll}
\mathrm{p} & =\text { rate of pressure rise }(\mathrm{psi} / \mathrm{h}) \\
\mathrm{c}_{\mathrm{a}} & =\text { constant }\left(1 / 29.13 \mathrm{~mol} / \mathrm{L} \times 1 / 1000 \mathrm{~L} / \mathrm{cm}^{3}\right) \\
\mathrm{R} & =\text { constant }\left(82.057 \mathrm{~cm}^{3} \mathrm{~atm} / \mathrm{mol} \mathrm{K}\right) \\
\mathrm{T}_{w} & =\text { temperature of waste }(355 \mathrm{~K}) \\
\mathrm{V}_{\mathrm{v}} & =\text { container void volume }(\mathrm{see} \text { Table } 2)\left(\mathrm{cm}^{3}\right) \\
\mathrm{r}_{\text {rea }} & =\text { Total generation rate }(\mathrm{see} \text { Table } 7)\left(\mathrm{cm}^{3} / \mathrm{h}\right) \\
\mathrm{c}_{\text {pre }} & =\text { pressure conversion }(14.7 \mathrm{psi} / \mathrm{atm})
\end{array}
$$

The total pressure rise to the time needed to reach the LFL can then be found using the times taken to reach $2.5 \%$ hydrogen gas by volume from Table 6 . The results for the Doorstop container are summarized in Table 7.

Table 7. Pressure Rise for the Doorstop.

\begin{tabular}{|l|c|c|c|}
\cline { 2 - 4 } \multicolumn{1}{c|}{} & \multicolumn{3}{c|}{ Waste Volume } \\
\cline { 2 - 4 } \multicolumn{1}{c|}{} & $1.6 \mathrm{ml}$ & $20 \mathrm{ml}$ & $125 \mathrm{ml}$ \\
\hline Total gas generation rate $\left(\mathrm{cm}^{3} / \mathrm{h}\right)$ & 0.00270 & 0.0356 & 0.219 \\
\hline Pressure rise to LFL (psi) & 0.910 & 0.911 & 0.911 \\
\hline Pressure rise to half of the LFL (psi) & 0.455 & 0.456 & 0.456 \\
\hline Pressure rise in 45 days (psi) & 0.52 & 3.19 & 4.24 \\
\hline
\end{tabular}




\section{ENGINEERING SAFETY EVALUATION}

Subject Hydrogen Gas Generation in the Doorstop Container____Page 8 of 13 $\begin{array}{ll}\text { Originator J.S. Boettger } & \text { Date } 12 / 16 / 96 \\ \text { Checker_.E. Mercado f.E. llewet } & \text { Date_12/16/96 }\end{array}$

V. Appendix:

Worst Case $-1.6 \mathrm{ml}$

Radcaic for Windows 1.0

File: DSTOPWC1.RAD

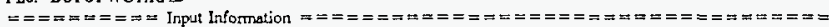

Date: $08-09-9608: 45$

Performed By: \&f Betis

Chocked By: f. E. Unat

Source from input:

Radionuclide: Curies:

C. $14 \quad 6.900-009$

Co-60 2.10e-005

$\operatorname{se} 79 \quad 7.40=010$

St $-90 \quad 1.20<-001$

$\mathrm{Y}-90 \quad 1.20 \mathrm{e}-001$

Te-99 5.10e-004

Ru-los $\quad 3.00=-009$

Rh-106 3.00e-009

St-125 $7.80 c-006$

1-129 2.70 - 007

Cs-134 $\quad 4.00=-007$

Cs- 137 4.30e-003

$\mathrm{Ba}-137 \mathrm{~m} \quad 4.20 \mathrm{c}-003$

Ce-144 1.50e-011

$P_{I+144} \quad 1.50 \mathrm{e}-011$

Eu-154 4.80e-004

Eu-155 2.20c-007

$\mathrm{Np}-237 \quad 4.30 c-005$

Pu-238 8.20e-006

Pu-239 6.90e-005

Pus 240 6.90e-005

Pu-241 1.60e-004

Am-241 $\quad 4.80 \mathrm{e}-004$

$\mathrm{Cm}-242 \quad 8.60 \mathrm{t}-012$

$\mathrm{Cm}-244 \quad 2.60 \mathrm{c}-000$

Waste Forn: Normal

Physical Form: Solid

Container Type: Doorstop Sample Carrier

Package Void Volume: $\quad 82.1 \mathrm{cc}$

Waste Volume; $\quad 1.60 \mathrm{ce}$

Waste Mass: $\quad 2.56$.

Waste True Density: $\quad 1.60 \mathrm{~g} / \mathrm{ce}$

Date to begin cource decay: 8:00 Aug. 9, 1996

Date conthiner caled: 8:00 Aug. 9, 1996

Days to decoy source before keal time: $\quad 0.00$ days 
ENGINEERING SAFETY EVALUATION

Subject Hydrogen Gas Generation in the Doorstop Container Originator I. S. Boettger OSB

Page 9 of 13

Checker J. E, Mercado

\section{Worst Case $-1.6 \mathrm{ml}$ (cont'd)}

Caleulate number of days sealed until $2.50 \%$ hydrogen is reached.

$\begin{array}{cll}\text { Entered G Values: } & & \\ \text { G Alpha } & \text { G Bets } & \text { G Garnma } \\ 0.476 & 0.119 & 0.119\end{array}$

Comments:

RadCaic calculations using:

Doorstop Sample Carier

Configuration 1 - Sample Pipette

Worst Case Scenario

Waste Volume: $1.6 \mathrm{ml}$

Fackage Void Volume: $82.1 \mathrm{ml}$

Waste Density: $1.6 \mathrm{~g} / \mathrm{ml}$

\begin{tabular}{|c|c|}
\hline \multicolumn{2}{|c|}{ The pealed container will generate 2.50 \% hydrogen in 90.94 days } \\
\hline This corresponds to date: & 7:00 Nov. 8,1996 \\
\hline H2 Volume: & $2.10 \mathrm{ce}$ \\
\hline H2 Generation Rate: & $0.000964 \mathrm{cc} / \mathrm{hour}$ \\
\hline Heat Generated: & 0.000852 Watts \\
\hline Partial Pressure (H2): & $2.60 \mathrm{kPa}$ \\
\hline Total Preseure (H2 and Air) & $\quad$ 104. $\mathrm{kPa}_{\mathrm{a}}$ \\
\hline
\end{tabular}


ENGINEERING SAFETY EVALUATION

Subject_Hydrogen Gas Generation in the Doorston Container Originator J.S. Boeitger \&\&

Checker J. E. Mercado

Page 10 of 13

Date $12 / 16 / 96$

Date $12 / 16 / 96$

Worst Case $-20 \mathrm{ml}$

Raceste for Windowa 1.0

File: DSTOPWC2.RAD

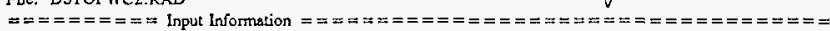

Date: $08-09.9609: 29$

Periomed By: of axthr.

Checked By: $\frac{d . \varepsilon, ~ M e c t}{0}$

Soure from input:

\begin{tabular}{|c|c|}
\hline Radionuclide: & Curies: \\
\hline C-14 & $8.60<-008$ \\
\hline C. 60 & $2.60 \mathrm{e}-004$ \\
\hline Se-79 & $9.20 \mathrm{e}-0.09$ \\
\hline Sr -90 & $1.60 e+\infty 00$ \\
\hline$Y .90$ & $1.60 e+000$ \\
\hline Tc-99 & $6.40 c-003$ \\
\hline Ru-106 & $3.80 e-008$ \\
\hline$R h-106$ & $3.80 e-008$ \\
\hline Sb-125 & $9.80 k-005$ \\
\hline I-129 & $3.40 \mathrm{e}-006$ \\
\hline Cs-134 & $5.000-006$ \\
\hline $\mathrm{Cs} \cdot 137$ & $5.40 e-002$ \\
\hline $\mathrm{Bz}-137 \mathrm{~m}$ & $5.20 c-002$ \\
\hline$C_{e-144}$ & $1.80<-010$ \\
\hline $\operatorname{Pr}-144$ & $1.80<-010$ \\
\hline Eu-154 & $6.00 \mathrm{c}-\infty 03$ \\
\hline Eu-155 & $2.80=-006$ \\
\hline$N_{p}-237$ & $5.40=-004$ \\
\hline Pui-238 & $1.00 e-004$ \\
\hline Pu-239 & $8.60=-004$ \\
\hline$P u-240$ & $8.600-004$ \\
\hline$P u-241$ & $2,00 e-003$ \\
\hline Ant-241 & $6.00 c-003$ \\
\hline $\mathrm{Cm}-242$ & $1.100-010$ \\
\hline $\mathrm{Cm} \cdot 244$ & $3.20 c-005$ \\
\hline
\end{tabular}

Waste Form: Normsl

Physical Form: Solid

Conteiner Type: Doorstop Sample Carrier

$\begin{array}{ll}\text { Package Void Volume: } & 177 . \mathrm{cc} \\ \text { Waste Volume: } & 20.0 \mathrm{cc} \\ \text { Waste Mass: } & 32.0 \mathrm{~g} \\ \text { Waste True Density: } & 1.60 \mathrm{~g} / \mathrm{cc}\end{array}$

Dale to begin source decay: 8:00 Aug. 9, 1996

Date container realed: 8:00 Aug. 9, 1996

Days to decay source before seal time: 0.00 dey"

Calculate sumber of days sealed until $2.50 \%$ hydrogen is reached. 


\section{HNF-SD-TP-SARP-023 ReV, 0}

ENGINEERING SAFETY EVALUATION

Subject Hydrogen Gas Generation in the Doorston Container

Originator I.S. Boettger ot

Checker J, E. Mercado

Page 11 of 13

Date $12 / 16 / 96$

Date $12 / 16 / 96$

\section{Worst Case - $20 \mathrm{ml}$ (cont'd)}

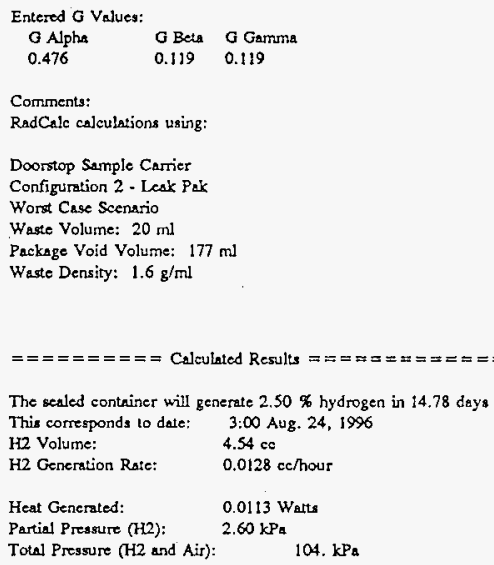


ENGINEERING SAFETY EVALUATION

Subject Hydrogen Gas Generation in the Doorstop Container_____ Page 12 of 13 Originator J.S. Boettger of B Date 12/16196

Checker J, E, Mercado $\longrightarrow$ Date $12 / 16 / 96$

\section{Worst Case $-125 \mathrm{ml}$}

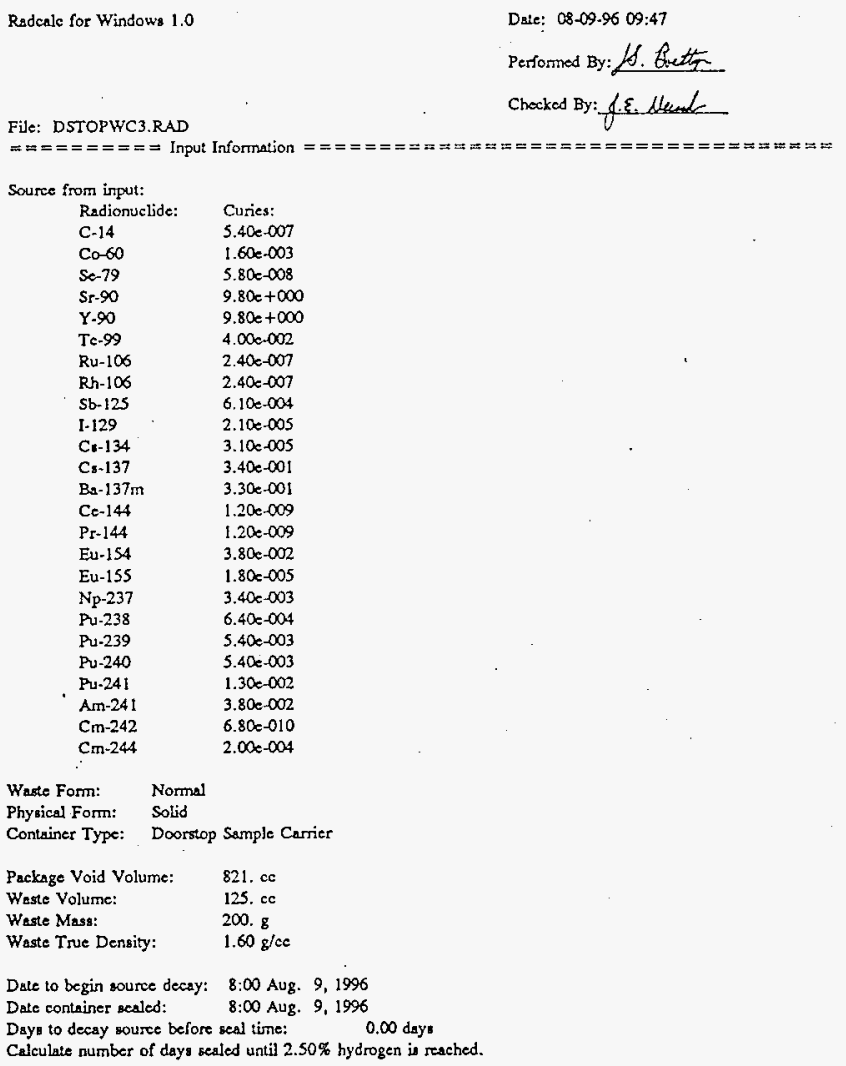

Date: $08-09-9609: 47$

Jotited By:

File: DSTOPWC3.RAD

Cheoked By: f.E. drunte 
HNF-SD-TP-SARP-023 Rev. 0

ENGINEERING SAFETY EVALUATION

Subject Hydrogen Gas Generation in the Doorstop Container

Originator I.S. Boettger OSz

Page 13 of 13

Checker J. E. Mercado

Worst Case - $125 \mathrm{ml}$ (cont'd)

$\begin{array}{cll}\text { Entered G Values: } & & \\ \text { G Alphe } & \text { G Bels } & \text { G Gamms } \\ 0.476 & 0.119 & 0.119\end{array}$

Corrments:

RadCale caloulations using:

Doorstop Sample Corricr

Configuration 3 - Paint Can

Worst Case Scenerio

Ware Volume: $125 \mathrm{ml}$

Packsge Void Volume: $821 \mathrm{ml}$

Waste Density: $1.6 \mathrm{~g} / \mathrm{ml}$

$== \pm \approx z==0=$ Cilculated Results

The sealed container will generate $2.50 \%$ hydrogen in 11.15 day.

This corresponds to date: 12:00 Aug. 20, 1996

H2 Volume: $\quad 21.0 \mathrm{ce}$

H2 Generztion Rate: $\quad 0.0787 \mathrm{ce} /$ hour

Heat Generated: $\quad 0.0694$ Watts

Partial Pressure (H2): $\quad 2.60 \mathrm{kPa}$

Total Pressure (H2 and Air): $\quad$ 104. kPa 


\subsubsection{Hydrogen Gas Generation in the Doorstop Container - Addendum}

ENGINEERING SAFETY EVALUATION

Subject Hydrogen Gas Generation in the Doorstop Container - Addendum _ Page 1 of 3 Originator I.S.Boetger / D Bette Date_1/15/96 Checker I. E. Mercado Date_1/15/96

\section{Objectives:}

This addendum shows hydrogen generation rates and shipping windows using several fractions of the worst case source term. These scenarios provide a more accurate representation of actual shipments. All calculational methods are identical to the original evaluation, thus only the necessary tabulated results are given in this addendum. Please refer to the original evaluation for a more detailed description of the analysis.

II. Results and Conclusions:

The following table summarizes the results for the added source term source term scenarios.

Table 1a. Summary of Results for the Doorstop Sample Carrier (75\% Worst Case).

\begin{tabular}{|l|c|c|c|}
\cline { 2 - 4 } \multicolumn{1}{c|}{} & \multicolumn{3}{|c|}{$75 \%$ of Worst Case } \\
\hline Payload volume & $1.6 \mathrm{ml}$ & $20 \mathrm{ml}$ & $125 \mathrm{ml}$ \\
\hline Half of the time to reach LFL & 50 days & 8 days & 6 days \\
\hline Pressure rise to $50 \%$ LFL (psi) & 0.454 & 0.454 & 0.454 \\
\hline Pressure rise in 45 days (psi) & 0.40 & 2.47 & 3.29 \\
\hline
\end{tabular}

Table 1b. Summary of Results for the Doorstop Sample Carrier (50\% Worst Case).

\begin{tabular}{|l|c|c|c|}
\cline { 2 - 4 } \multicolumn{1}{c|}{} & \multicolumn{3}{c|}{$50 \%$ of Worst Case } \\
\hline Payload volume & $1.6 \mathrm{ml}$ & $20 \mathrm{ml}$ & $125 \mathrm{ml}$ \\
\hline Half of the time to reach LFL & 70 days & 11.5 days & 8.5 days \\
\hline Pressure rise to 50\% LFL (psi) & 0.452 & 0.452 & 0.452 \\
\hline Pressure rise in 45 days (psi) & 0.29 & 1.76 & 2.33 \\
\hline
\end{tabular}

Table 1c. Summary of Results for the Doorstop Sample Carrier (25\% Worst Case).

\begin{tabular}{|l|c|c|c|}
\hline \multicolumn{1}{c|}{} & \multicolumn{3}{|c|}{$25 \%$ of Worst Case } \\
\hline Payload volume & $1.6 \mathrm{ml}$ & $20 \mathrm{ml}$ & $125 \mathrm{ml}$ \\
\hline Half of the time to reach LFL & 117 days & 19 days & 14.5 days \\
\hline Pressure rise to 50\% LFL (psi) & 0.447 & 0.447 & 0.447 \\
\hline Pressure rise in 45 days (psi) & 0.17 & 1.04 & 1.38 \\
\hline
\end{tabular}


ENGINEERING SAFETY EVALUATION

Subject_Hydrogen Gas Generation in the Doorston Container - Addendum Page 2 of 3

$\begin{array}{lll}\text { Originator J.S. Boettger } & \text { Date } 1 / 15 / 96 \\ \text { Checker_J.E. Mercado } & \text { D } & \text { D } \\ \text { Date } 1 / 15 / 96\end{array}$

For all cases in this report, the LFL of the mixture is reached when hydrogen gas equals $2.5 \%$ by volume. The NRC allows a shipping envelope of half the time it takes to reach $5 \%$ hydrogen gas by volume or the LFL of gas mixtures (NRC 1984). Because the LFL of the gas mixture is reached when the hydrogen gas reaches $2.5 \%$ by volume (WHC 1995), the shipping window is determined to be half of the time it takes to reach $2.5 \%$ hydrogen gas.

\section{Engineering Evaluation:}

The worst case source term consists of the highest possible concentration of each radionuclide across all tanks. However, an actual shipment may contain radionuclides in concentrations significantly less than those in the worst case source term. Therefore, source terms were developed consisting of $75 \%, 50 \%$, and $25 \%$ of the worst case concentrations. If the concentrations of all radionuclides are at or below the given percentage, then that percentage source term can be used. The source term percentage concentrations are given in Part B, Section 4.3 .3 of the Doorstop SARP.

The radiolytic hydrogen generation rate is directly proportional to the concentration of the radionuclides. The chemical hydrogen generation rate is independant of radionuclide concentration. Table $2 \mathrm{a}$ is a reproduction of Table 6 from the original evaluation, while Tables $2 b$ through $2 d$ show the new results using the source term percentages.

Table 2a. Total Hydrogen Gas Generation Rates for the Doorstop (Worst Case).

\begin{tabular}{|l|c|c|c|}
\cline { 2 - 4 } \multicolumn{1}{c|}{} & \multicolumn{3}{c|}{ Waste Volume } \\
\cline { 2 - 4 } \multicolumn{1}{c|}{} & $1.6 \mathrm{ml}$ & $20 \mathrm{ml}$ & $125 \mathrm{ml}$ \\
\hline Chemical generation $\left(\mathrm{cm}^{3} / \mathrm{h}\right)$ & 0.000124 & 0.00155 & 0.00971 \\
\hline Radiolytic generation $\left(\mathrm{cm}^{3} / \mathrm{h}\right)$ & 0.000964 & 0.0128 & 0.0787 \\
\hline Total $\mathrm{H}_{2}$ generation $\left(\mathrm{cm}^{3} / \mathrm{h}\right)$ & 0.00109 & 0.0144 & 0.0884 \\
\hline Time to reach LFL of mixture & 78 days & 13 days & 9.7 days \\
\hline Half the time to reach $\mathrm{LFL}$ & 39 days & 6.4 days & 4.8 days \\
\hline
\end{tabular}


Tabie 2b. Total Hydrogen Gas Generation Rates for the Doorstop (75\% of Worst Case)

\begin{tabular}{|l|c|c|c|}
\cline { 2 - 4 } \multicolumn{1}{c|}{} & \multicolumn{3}{|c|}{ Payload Volume } \\
\cline { 2 - 4 } \multicolumn{1}{c|}{} & $1.6 \mathrm{ml}$ & $20 \mathrm{ml}$ & $125 \mathrm{ml}$ \\
\hline Chemical generation $\left(\mathrm{cm}^{3} / \mathrm{h}\right)$ & 0.000124 & 0.00155 & 0.00971 \\
\hline Radiolytic generation $\left(\mathrm{cm}^{3} / \mathrm{h}\right.$ & 0.000723 & 0.00960 & 0.0590 \\
\hline Total $\mathrm{H}_{2}$ generation $\left(\mathrm{cm}^{3} / \mathrm{h}\right)$ & 0.000847 & 0.0112 & 0.0687 \\
\hline Time to reach LFL of mixture & 100 days & 16 days & 12 days \\
\hline Half the time to reach LFL & 50 days & 8 days & 6 days \\
\hline
\end{tabular}

Table 2c. Total Hydrogen Gas Generation Rates for the Doorstop (50\% of Worst Case)

\begin{tabular}{|l|c|c|c|}
\cline { 2 - 4 } \multicolumn{1}{c}{} & \multicolumn{3}{c|}{ Payload Volume } \\
\cline { 2 - 4 } \multicolumn{1}{c|}{} & $1.6 \mathrm{ml}$ & $20 \mathrm{ml}$ & $125 \mathrm{ml}$ \\
\hline Chemical generation $\left(\mathrm{cm}^{3} / \mathrm{h}\right)$ & 0.000124 & 0.00155 & 0.00971 \\
\hline Radiolytic generation $\left(\mathrm{cm}^{3} / \mathrm{h}\right.$ & 0.000482 & 0.00640 & 0.0394 \\
\hline Total $\mathrm{H}_{2}$ generation $\left(\mathrm{cm}^{3} / \mathrm{h}\right)$ & 0.000606 & 0.00795 & 0.0491 \\
\hline Time to reach LFL of mixture & 140 days & 23 days & 17 days \\
\hline Half the time to reach LFL & 70 days & 11.5 days & 8.5 days \\
\hline
\end{tabular}

Table 2d. Total Hydrogen Gas Generation Rates for the Doorstop (25\% of Worst Case)

\begin{tabular}{|l|c|c|c|}
\multicolumn{1}{c}{} & \multicolumn{3}{c|}{ Payload Volume } \\
\cline { 2 - 4 } \multicolumn{1}{c|}{} & $1.6 \mathrm{ml}$ & $20 \mathrm{ml}$ & $125 \mathrm{ml}$ \\
\hline Chemical generation $\left(\mathrm{cm}^{3} / \mathrm{h}\right)$ & 0.000124 & 0.00155 & 0.00971 \\
\hline Radiolytic generation $\left(\mathrm{cm}^{3} / \mathrm{h}\right.$ & 0.000241 & 0.00320 & 0.0197 \\
\hline Total $\mathrm{H}_{2}$ generation $\left(\mathrm{cm}^{3} / \mathrm{h}\right)$ & 0.000365 & 0.00475 & 0.0294 \\
\hline Time to reach LFL of mixture & 234 days & 38 days & 29 days \\
\hline Half the time to reach LFL & 117 days & 19 days & 14.5 days \\
\hline
\end{tabular}


HNF-SD-TP-SARP-023 Rev. 0

This page intentionally left blank.

B9-18 
HNF-SD-TP-SARP-023 Rev, 0

\subsection{PACKAgE TIEDOWN SYSTEM EVALUATION}

\subsection{TIEDOWN EVALUATION}

The N-55 package containing the Doorstop Sample Carrier System is attached to its transport vehicle by a $1 \mathrm{ift} / \mathrm{t}$ iedown assembly as shown in Figures B10-1 and B10-2. The $\mathrm{N}-55$ is held in place by a frame, which fits over the top of the overpack and is held in place by four tiedown straps. The tiedown straps connect the frame to a baseplate, which, in turn, is bolted to the bed of the truck. The entire assembly except for the $\mathrm{J}$ bolts forms the tiedown assembly. The four tiedown straps are identified throughout the tiedown system evaluation as cables. While the parts are mislabeled, the evaluations are correct. The loads and resulting stresses are evaluated in Part B, Section 10.2. The evaluations show that the tiedown meets the regulatory requirements.

Figure B10-1. Tiedown Assembly Dimensions.

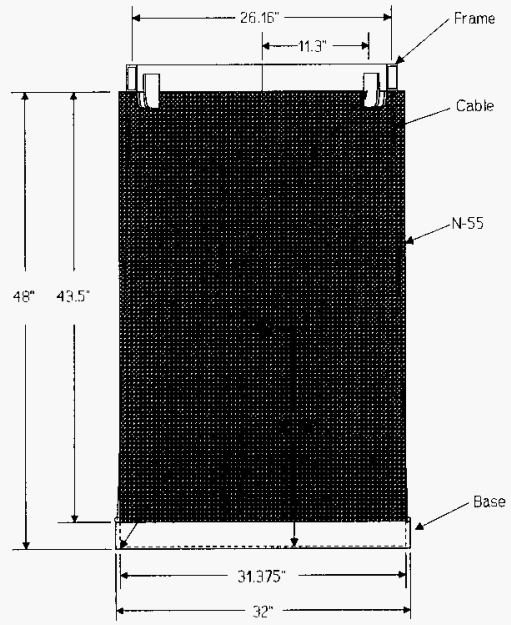


Figure B10-2. Tiedown Dimensions, Plan View.

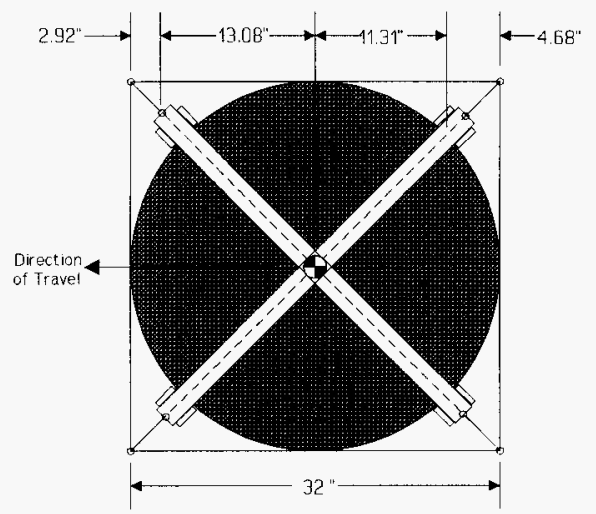

\subsection{TIEDOWN DEVICES}

The tiedown assembly is loaded by transportation loads as defined by 49 CFR 393.102 and 49 CFR 393.104. The required tiedown loads due to an acceleration of $0.5 \mathrm{~g}$ acting on the package center of gravity are calculated in Part B, Section 10.2.1. This analys is considers vertical and lateral directions as well as an acceleration applied at a $45^{\circ}$ angle to the direction of travel. The effect of gravity is conservatively ignored in the analyses below. This is because the specified loadings are not meant to reflect actual loads experienced by the tiedowns, but rather are to demonstrate a safe margin above expected transportation loads. The loaded gross weight of the $\mathrm{N}-55$ in the Doorstop container configuration is assumed to be $363 \mathrm{~kg}(800 \mathrm{lb})$ (390 $\mathrm{kg}$ [860 1b] including the tiedown frame). Figures $\mathrm{B} 10-1$ and $\mathrm{B10}-2$ i17ustrate the assembled package and tiedown assembly with appropriate dimensions.

The transportation load-induced stresses are calculated in Part B, Sections 10.2 .2 through 10.2 .8 and are to be compared with the manufacturer's working load 1 imits for tiedown hardware. These are normally $1 / 5$ of breaking loads. For the tiedown frame the working load limit is considered to be the lesser of $1 / 3$ of material yield stress or $1 / 5$ of material ultimate stress. A safety margin, SM, will be calculated to evaluate all stress calculations against the above allowables.

\subsubsection{Acceleration Directional Loadings}

The following sections evaluate the cable tension loadings based on vertical, horizontal, and oblique acceleration. 
10.2.1.1 Vertical Direction Acceleration. Assume that only two of the tiedown straps are effective in resisting an upward acceleration of $0.5 \mathrm{~g}$ :

$$
T=\frac{0.5 F}{\sin 84.6^{\circ}}=\frac{(0.5)(0.5)(800)}{0.996}=200.81 t
$$

10.2.1.2 Longitudinal and Lateral Direction Accelerations. Assume the package pivots at its lower corner (point $A$ in Figure B10-3) and that the upper opposite corner of the $\mathrm{N}-55$ forms a pivot point for the tiedown frame. This occurs because the frame is not tied to the overpack, but is only restrained from moving horizontally with respect to the $\mathrm{N}-55$ by the tabs welded to the tiedown frame. All cables are thus in tension to provide equilibrium to the tiedown frame. The force components are shown in Figure B10-3.

Figure B10-3. Transport Load Components.

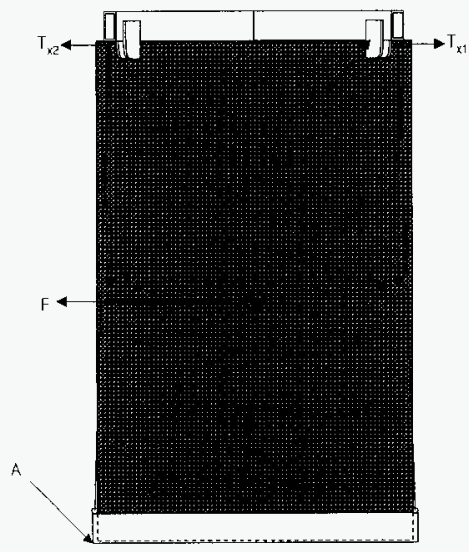

Writing an expression summing moments of the overall system about point $A$, using the dimensions shown in Figures $\mathrm{B} 10-2$ and $\mathrm{B} 10-3$ :

$$
(23.86) F=(2.92) T_{y z}-(48) T_{x 2}+(29.08) T_{y 1}+(48) T_{x 1}
$$

Using the assumption that the tiedown frame is free to pivot about point $B$ results in the following expression for $T_{\gamma_{2}}$ in terms of $T_{y 1}$ : 


$$
\begin{gathered}
\text { (24.39) } T_{y 2}=(1.77) T_{y 1} \\
T_{y 2}=(0.073) T_{y 1}
\end{gathered}
$$

Since the tiedown cables can carry only tensile loads and given that all cables are oriented symmetrically with respect to the cask (again using dimensions shown in Figures $\mathrm{B} 10-1$ and $\mathrm{B} 10-2$ ), the horizontal component of the tension in any cable can be expressed in terms its vertical component:

$$
T_{\mathbf{x}}=\frac{2.92}{43.5} T_{y}=(0.067) T_{y}
$$

Substituting into the above expression, $F$ can be expressed in terms of $\mathrm{T}_{\mathrm{y} 1}$ :

$$
\begin{aligned}
& (23.86) F=(2.92)(0.073) T_{y z}-(48)(0.067)(0.073) T_{y_{1}}+(29.08) T_{y 1}+(48) \\
& =(32.27) T_{y 2} \\
& T_{y 1}=(0.739) \mathrm{F}
\end{aligned}
$$

This cable value represents the sum of the vertical tension component in both aft cables. The horizontal component $T_{x 1}$ is not only the sum of both cables but also the component in the plane of the page. Since the vertical plane containing the cables is at a $45^{\circ}$ angle to the page, the horizontal component must be increased by a factor of 1.414. Applying these corrections:

$$
\begin{gathered}
T_{Y}=\frac{T_{Y 1}}{2}=(0.370) \mathrm{F} \\
T_{X}=(1.414)(0.067) T_{Y}=(0.035) \mathrm{F}
\end{gathered}
$$

The total tensile load in either of the aft cables is then:

$$
T_{A}=\sqrt{(0.37)^{2}+(0.035)^{2}} F=(0.372) F
$$

A similar procedure for the forward cables results in a value of

$$
T_{F}=(0.027) \mathrm{F}
$$

Applying a $0.5 \mathrm{~g}$ load to the center of gravity of the $390 \mathrm{~kg}(860 \mathrm{lb}) \mathrm{load}$ results in the following cable tension values:

$$
\begin{aligned}
& T_{A}=(0.372) \quad(430)=1601 b \\
& T_{F}=(0.029) \quad(430)=121 b
\end{aligned}
$$


10.2.1.3 0blique Direction Acceleration. Assume a load is directed at an angle of $45^{\circ}$ from the direction of travel. Dimensions for this orientation are shown in Figure B10-4. Force components are similar to those shown in Figure B10-3. Conservatively assume only the tiedown cables at the front and back of the package are effective. Summing moments about $A$ :

$$
\text { (23.86) } F=-(2.81) T_{y 2}-(48) T_{x 2}+(34.19) T_{y 1}+(48) T_{x 1}
$$

Again, assuming the tiedown frame pivots about point $B$ shown above and that the two center cables are not loaded:

$$
T_{y^{2}}=(0.0822) T_{y 1}
$$

The cable angle is slightly different for this orientation, resulting in the following ratio of horizontal-to-vertical force in both forward and aft cables:

$$
T_{X}=\frac{4.125}{43.5} T_{Y}=(0.0948) T_{Y}
$$

Figure B10-4. Oblique Direction Dimensions.

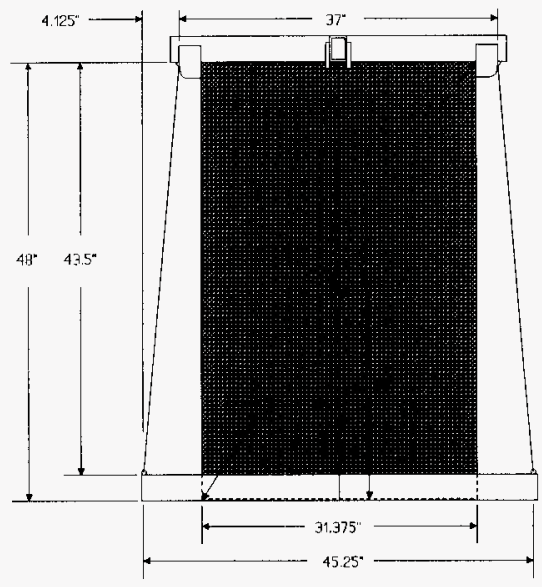




$$
\text { HNF-SD-TP-SARP-023 Rev. } 0
$$

Substituting gives $T_{y 1}$ and $T_{x 1}$ in terms of $F$ :

$$
\begin{gathered}
T_{y 1}=\frac{23.86}{38.13} F=(0.626) F \\
T_{x 1}=(0.0948)(0.626) F=(0.059) F
\end{gathered}
$$

The total tensile load in the aft cable is:

$$
T_{A}=\sqrt{0.626^{2}+0.059^{2}} F=0.629 F
$$

Similarly, the forward cable load is:

$$
T_{F}=\sqrt{0.048^{2}+0.005^{2}} F=0.048 F
$$

Substituting a $0.5 \mathrm{~g}$ load to the center of gravity of the $390-\mathrm{kg}$ (860-1b) load results in the following cable tension values:

$$
\begin{aligned}
& T_{A}=(0.629) \quad(430)=270 \mathrm{Ib} \\
& T_{F}=(0.048) \quad(430)=21 \mathrm{Ib}
\end{aligned}
$$

The loads calculated previously are summarized in the following list. They are considerably lower than the lifting loads. Therefore, only components not loaded in lifting will be addressed in the following analyses.

1. Load due to $0.5 \mathrm{~g}$ forward acceleration of the payload: $73 \mathrm{~kg}$ (160 lb)

2. Load due to $0.5 \mathrm{~g}$ oblique $\left(45^{\circ}\right.$ sideward) acceleration of the payload: $122 \mathrm{~kg}(270 \mathrm{lb})$

3. Load due to $0.5 \mathrm{~g}$ upward acceleration of the payload: $91 \mathrm{~kg}$ (201 1b).

\subsubsection{Tiedown Frame Eyebolt}

The eyebolt in each arm of the tiedown frame is the attachment point for the tiedown strap. Thus, the maximum load calculated for each eyebolt is $122 \mathrm{~kg}(270 \mathrm{lb})$. Listed working $1 \mathrm{imit}$ for a Crosby G-277 $\frac{1}{2} \times 6$ shoulder nut eyebolt is $998 \mathrm{~kg}(2,200 \mathrm{lb})$. Again, this component easily meets the working strength requirements.

\subsubsection{Stops Welded to Tiedown Frame}

Eight stops are welded to the tiedown frame as a means of restraining the $\mathrm{N}-55$ when it is placed in position on top of the $\mathrm{N}-55$. The worst-case loading is considered to be the oblique transport loading analyzed previously, which 
HNF-SD-TP-SARP-023 Rev. 0

is reacted by a single set of stops. The previous load determination resulted in a horizontal stress of approximately $9 \mathrm{~kg}(20 \mathrm{lb})$. This load produces negligible stress in the stops or the attaching welds.

\subsubsection{Tiedown Cables}

As shown previously, the maximum load seen by a tiedown cable is $122 \mathrm{~kg}$ $(270 \mathrm{1b})$. The working strength of a cable is required to be at least 0.5 times the maximum load calculated. The weakest portion of the cable assembly is the buckle with a working load limit of $907 \mathrm{~kg}(2,000 \mathrm{lb})$. Therefore, the tiedown straps easily meet requirements.

\subsubsection{Tiedown Base}

The tiedown base consists of a rectangular frame constructed of $2.5 \times 2.5$ $\times 0.375$ angle iron. The frame forms a receptacle for the base of the $\mathrm{N}-55$ and reacts to all loads transmitted through the base of the $\mathrm{N}-55$. In addition, lengths of $*$ rod are welded to the four corners of the frame to form attachment points for the tiedown cables. The tiedown base is bolted to the transport vehicle bed and frame.

\subsubsection{Frame Tiedown Attachments}

The rod is formed into a $U$ shape with the ends welded to the outside of the frame angles as shown in Figure B10-5. The welds are $1 / 1$ in. by 2.5 in. and are $\mathrm{placed}$ on both sides of the rod. The radius of curvature of the centerline of the rod is approximately $1.3 \mathrm{in}$.

The tiedown attachment can be considered as one-half of a chain link with a central stud joining the two sides of the link as was done with the lifting bail above. The maximum bending moment occurs at the point of loading.

$$
M_{0}=\frac{W R C_{1}}{2}
$$

Where $C_{1}$ is a function of the ratio $L / R$

$$
C_{1}=\frac{(k+2)\left[k^{3}+6 k^{2}+12 k(4-\pi)+48(\pi-3)\right]}{k^{4}+4 \pi k^{3}+48 k^{2}+24 \pi k+24\left(\pi^{2}-8\right)}
$$

and $k=L / R$.

The value of $L$ is approximately $2.5 \mathrm{in}$. with $R=1.3 \mathrm{in}$. given above. Substituting $k=2.5 / 1.3=1.923$ gives $C_{1}=0.466$, and thus the maximum moment becomes 


$$
M_{0}=\frac{270(1.3)(0.466)}{2}=82 \mathrm{in}-1 \mathrm{~b}
$$

Similarly, a tensile load, $\mathrm{H}$, is produced at the point of loading

$$
H=\frac{W C_{2}}{2}
$$

Where $C_{2}$ is given by

$$
C_{2}=\frac{12(k+2)[(\pi-2) k+2(4-\pi)]}{k^{4}+4 \pi k^{3}+48 k^{2}+24 \pi k+24\left(\pi^{2}-8\right)}
$$

Substituting gives $C_{2}=0.392$ and the tensile load becomes

$$
H=\frac{270(0.392)}{2}=531 b
$$

At the point of loading, on the outer surface the maximum tensile stress is due to both the tensile loading, $H$, and the moment, $M_{0}$. The stress due to $\mathrm{H}$ is

$$
S_{t}=\frac{H}{A}=\frac{53}{0.11}=482 p s i
$$

The bending stress can be calculated for a curved beam using Roark (Roark and Young 1975) Table 16 , Case 2 with $R / c=6.93$. The correction factor for the inner surface is by interpolation, $k_{i}=1.12$.

The section modulus of the tiedown attachment is:

$$
S_{x}=\frac{\pi d^{3}}{32}=0.0052 \mathrm{in}^{3}
$$

The bending stress on the inner surface of tiedown attachment (compressive):

$$
f_{b}=k_{i} \frac{M_{b}}{S}=1.12 \frac{82}{0.0052}=17,662 \text { psi }
$$

The sum of the tensile stress and the compressive bending stress is:

$$
S_{T}=S_{t}+S_{b}=482+-17,662=-17,180 p s i
$$


From above the maximum stress in the tiedown attachment occurs at the point of loading. The safety margin is:

$$
S M=\frac{(58,000 / 5)}{17,180}=0.675
$$

Assume the tensile load is equal to the maximum cable load calculated previously and that the entire load is reacted by one leg of the attachment.

$$
\begin{gathered}
f=T / A=270 /\left(0.25 \pi 0.375^{2}\right)=2,444.1 b \\
S M=\frac{11,600}{2,444}=4.75
\end{gathered}
$$

The shear stress in the attachment weld is conservatively assumed to result from the entire load being carried by one leg of the attachment.

$$
\begin{aligned}
A_{W}=2(2.5) & =5.0 \mathrm{in} . \\
f_{W}=\frac{T}{A_{W}}=\frac{270}{5.0} & =54.01 \mathrm{~b} / \mathrm{in}
\end{aligned}
$$

The allowable weld load for a $1 / 3-$ in. weld is:

$$
\begin{gathered}
\tau_{w}=(0.6)(0.125)(.707)(58,000 / 5)=615 \mathrm{lb} / \mathrm{in} \\
S M=\frac{615}{54.0}=11.40
\end{gathered}
$$

\subsubsection{Tiedown Base Frame}

The frame carries the loads from the $\mathrm{N}-55$ to the bed and frame of the transport vehicle. The bearing load from the base of the cask is carried from the center of the beam to the frame bolts. The frame can be considered chocking as defined in 49 CFR 393.104. Therefore, it must resist a deceleration of $20 \mathrm{ft} / \mathrm{s}^{2}(0.6 \mathrm{~g})$. Using a payload weight (including the tiedown frame) of 860 lb the horizontal load, $F$, becomes:

$$
F_{A}=(0.62)(860)=5332 b
$$

Consider the frame carrying the load to be a simple beam 25.5 in. in length. The section modulus, $S_{y}$ of a $2.5 \times 2.5 \times 0.375$ angle, is $0.566 \mathrm{in}^{3}$.

$$
\begin{gathered}
M=\frac{F_{A} I}{4}=\frac{533(25.5)}{4}=3,399 \mathrm{in}-1 \mathrm{~b} \\
f_{b}=\frac{M}{S_{y}}=\frac{3,399}{0.566}=6,005 \mathrm{psi} \\
S M=\frac{11,600}{6,005}=1.93
\end{gathered}
$$


Figure B10-5. Tiedown Base Frame.

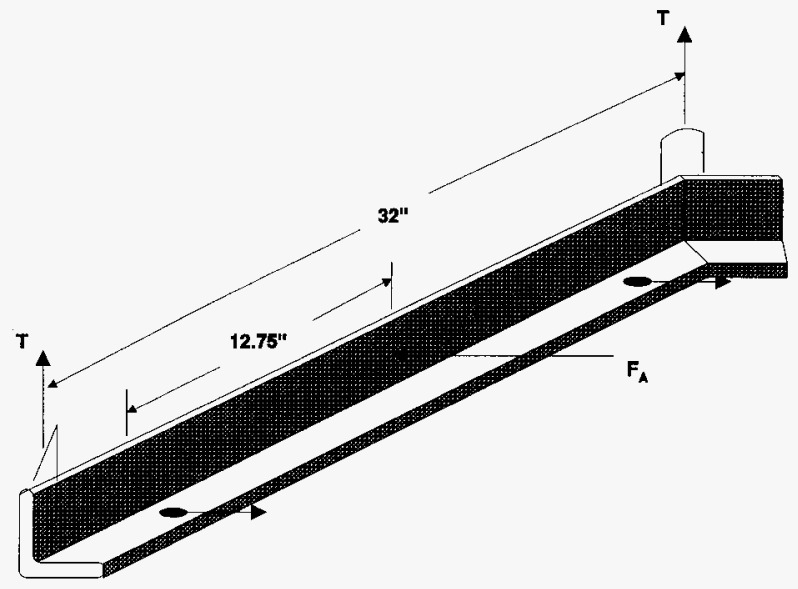

\subsubsection{Bolts}

The frame carrying the $\mathrm{N}-55$ is attached to the truck bed with $4 \frac{1}{2}-13$ UNC bolts of A-307 materia] $\left(F_{u}=60,000 \mathrm{psi}\right)$. Assume two of the bolts react the moment of payload experiencing a $0.62 \mathrm{~g}$ deceleration. The moment arm from the pivot point of the $\mathrm{N}-55$ to the bolts is assumed to be 32 in.

From the loads analysis above, the moment due to a $0.5 \mathrm{~g}$ acceleration is:

$$
M_{\mathrm{A}}=(860)(23.86)=20,520 \mathrm{in}-1 \mathrm{~b}
$$

The force per bolt is then:

$$
T_{b}=\frac{M_{A}}{21}=\frac{20,520}{2(32)}=3211 t
$$

Tensile area of the bolt is $0.142 \mathrm{in}^{2}$. Bolt stress is then:

$$
\begin{aligned}
f_{b}=T_{b} / A & =321 / 0.142=2,258 \mathrm{psi} \\
S M & =\frac{60,000 / 5}{2,258}=5.31
\end{aligned}
$$

Due to the large margin for the bolts, the additional analyses involving the bolts are not considered necessary. 
HNF-SD-TP-SARP-023 Rev. 0

\subsection{ATTACHMENTS AND RATINGS}

The following attachments and ratings were used to evaluate the tiedown system:

\begin{tabular}{|l|c|}
\hline \multicolumn{1}{|c|}{ Attachment } & Rating \\
\hline \hline Frame eyebolt & $1,000 \mathrm{~kg}(2,200 \mathrm{lb})$ \\
\hline Tiedown cables & $907 \mathrm{~kg}(2,000 \mathrm{lb})$ \\
\hline Tiedown base & $1 / 3 \mathrm{~S}_{\mathrm{y}}$ \\
\hline Tiedown bolts & $1 / 5 \mathrm{~S}_{\mathrm{u}}$ \\
\hline
\end{tabular}

\subsection{REFERENCES}

Roark, R. J., and W. C. Young, 1975, Formulas for Stress and Strain, Fifth Edition, McGraw Hill Book Company, New York, New York.

Blake, Alexander, 1960, Practical Stress Analysis in Engineering Design, Second Edition, Marcel Dekker, Inc., New York, New York. 
HNF-SD-TP-SARP-023 Rev. 0

This page intentionally left blank. 


\begin{tabular}{|c|c|c|c|c|c|}
\hline \multicolumn{6}{|c|}{ DISTRIBUTION SHEET } \\
\hline \multirow{2}{*}{$\begin{array}{l}\text { To } \\
\text { Distribution }\end{array}$} & \multirow{2}{*}{\multicolumn{3}{|c|}{$\begin{array}{l}\text { From } \\
\text { Packaging Engineering }\end{array}$}} & \multicolumn{2}{|c|}{ Page 1 of 1} \\
\hline & & & & \multicolumn{2}{|c|}{ Date $02 / 26 / 97$} \\
\hline \multicolumn{4}{|c|}{ Project Title/Work Order } & \multicolumn{2}{|c|}{ EDT No. 619550} \\
\hline \multicolumn{4}{|c|}{$\begin{array}{l}\text { Safety Analysis Report for Packaging (Onsite) Doorstop Sample } \\
\text { Carrier System (HNF-SD-TP-SARP-023) }\end{array}$} & CN No. NA & \\
\hline Name & MSIN & $\begin{array}{c}\text { Text } \\
\text { With All } \\
\text { Attach. }\end{array}$ & Text Only & $\begin{array}{l}\text { Attach./ } \\
\text { Appendix } \\
\text { Only }\end{array}$ & $\begin{array}{l}\text { EDT/ECN } \\
\text { Only }\end{array}$ \\
\hline $\begin{array}{l}\text { P. K. Bhatia } \\
\text { S. L. Brey } \\
\text { D. D. Carlson } \\
\text { D. W. Claussen } \\
\text { R. L. Clawson } \\
\text { D. M. Edmonson } \\
\text { J. G. Field } \\
\text { M. A. Green } \\
\text { L. M. Hay } \\
\text { C. R. Hoover } \\
\text { P. Jennings } \\
\text { J. W. Lawson } \\
\text { M. L. Martin } \\
\text { M. L. McElroy } \\
\text { F. J. Reitz } \\
\text { S. M. Stahl } \\
\text { Central Files } \\
\text { NS Information Center (DOE-HQ-5) }\end{array}$ & $\begin{array}{l}\text { R2-54 } \\
\text { T6-12 } \\
\text { T6-51 } \\
\text { S7-55 } \\
\text { H1-14 } \\
\text { T6-09 } \\
\text { H1-15 } \\
\text { X3-56 } \\
\text { H1- } 15 \\
\text { H1-15 } \\
\text { R2-84 } \\
\text { X7-02 } \\
\text { T6-20 } \\
\text { S7-07 } \\
\text { S7-12 } \\
\text { R2-54 } \\
\text { A3-88 }\end{array}$ & 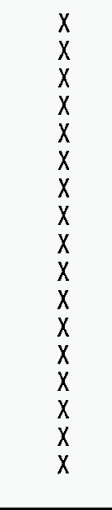 & & & \\
\hline
\end{tabular}

